\title{
After the Urban Crisis: New York and the Rise of Inequality
}

\author{
Edited by Themis Chronopoulos and Jonathan Soffer \\ Forthcoming as a special issue of the Journal of Urban History
}

\section{Table of Contents and Abstracts}

\section{Introduction. After the Urban Crisis: New York and the Rise of Inequality \\ by Themis Chronopoulos and Jonathan Soffer}

\section{"I am Not Co-Op!" The Struggle over Middle-Class Housing in 1970s New York}

\section{by Benjamin Holtzman}

In 1970s New York, some landlords and major real estate associations argued that New York could stem the exodus of middle-income residents by creating greater opportunities for homeownership in a city that had long been dominated overwhelmingly by renters. They proposed converting middle-income rental housing into cooperatives, a process that would also enable former landlords to profit handsomely. Tenants, however, widely rejected apartment ownership, preferring the security of rent-regulated housing. This article traces the ensuing struggles between tenants, the real estate industry, and city officials over the nature of moderate and middle-income housing in New York. The eventual success of the real estate industry enabled cooperative conversions to expand dramatically in the 1980s, but only by bargaining with tenants and activists, offering tenants non-eviction plans, and heavily discounted insider prices. This process helped to transform the city by underwriting a momentous turnaround in the real estate market, while signaling a larger embrace of market deregulation.

\section{"A Shelter Can Tip the Scales Sometimes": Disinvestment, Gentrification, and the Neighborhood Politics of Homelessness in 1980s New York City}

\section{by Ariel Eisenberg}

In the 1980s, visible homelessness became one of the most pressing problems in New York City. While most New Yorkers expressed sympathy for the homeless, many of them also resisted efforts to site shelters and service facilities in their neighborhoods. But far from being simply a case of NIMBY (Not In My Back Yard) sentiment, protests over the placement of these facilities arose in the context of decades-long neighborhood movements against urban disinvestment, and the beginning of gentrification in some New York City neighborhoods. I argue that understanding this history is crucial to parsing the complex politics of anti-homeless facility protests in the 1980s, and to understanding the 
rise of "quality of life" policies that would govern many neoliberal urban spaces by the 1990s.

\section{The Guardian Angels: Law and Order and Citizen Policing in New York City by Reiko Hillyer}

This article explores the rise of the Guardian Angels, a community patrol organization founded in 1979 in New York City by Curtis Sliwa and composed mainly of black and Latino youths. The group emerged in an era of economic restructuring coupled with a rising fear of crime. The Guardian Angels merit attention because of their peculiar relationship to the rise of law and order politics. They demonstrate that the fear of crime was neither the monopoly of the white middle class nor merely a construction of politicians. Black and Latino Guardian Angels were agents of community crime control who drew on existing customs of self-determination and distrust of the police. Ultimately, however, the activities and the rhetoric of the Guardian Angels contributed to the rise of a conservative discourse that justified the strengthening of the police state, anxiety about crime, and the gentrification of neighborhoods.

\section{The Rebuilding of the South Bronx after the Fiscal Crisis by Themis Chronopoulos}

This article explores the rebuilding of the South Bronx from 1977 to 2013. This rebuilding represents an important public policy accomplishment, since the South Bronx was one of the most physically devastated areas in the United States. In terms of economic policy, the rebuilding of the South Bronx defies linear narratives. On the one hand, public-private partnerships, which represent some of the most important features of urban neoliberalism were used heavily in the revitalization of the South Bronx. Community organizations that had been rebuilding areas in the South Bronx in the 1970s and the 1980s were required to conform to the requirements of the market, if they were to continue participating in urban development. On the other hand, the building of housing for low- and moderate-income people is not exactly a neoliberal economic policy, since these housing units were built with public subsidies and regulated by government agencies. In its insistence to rebuild the South Bronx as well as other physically devastated areas, the city government of New York became involved in creative financing by incorporating non-government organizations that were ran by accomplished businesspeople but remained non-profit. And whatever the original intentions of city administrations in building and preserving affordable housing in the South Bronx may have been, the accommodation of so many low income people performing low-paying but essential jobs, has contributed to the making of a more vibrant urban economy, even if these same people are not necessarily the ones benefitting from New York's economic dynamism. 


\section{Contributors}

Themis Chronopoulos is a lecturer in American History and Culture at the University of East Anglia in Norwich, United Kingdom. He is the author of Spatial Regulation in New York City: From Urban Renewal to Zero Tolerance (New York: Routledge, 2011). He is currently writing a book titled When the Government Disappears: Inadequate Municipal Service Delivery and the Decline of New York City, 1945-1985.

Ariel Eisenberg is Assistant Professor of History and Interdisciplinary Studies at Kennesaw State University, where she teaches women's history and women, gender, and sexuality studies. She is currently writing a book entitled "Save Our Streets and Shelter Our Homeless": The Homeless Crisis in Urban America in the 1980s.

Reiko Hillyer is an assistant professor of history at Lewis and Clark College in Portland, Oregon. Her first book, Designing Dixie: Tourism, Memory, and Urban Space in the New South, concerns the uses of public memory and tourism in fostering sectional reconciliation and economic development in the American South in the decades following the Civil War.

Benjamin Holtzman is a historian trained in the intersections of political, social, and economic histories of the twentieth century, with particular focus on politics, capitalism, cities and suburbs, social movements, and race. His research has appeared in Space and Culture, Radical Society, and several edited collections. He is a Ph.D. candidate in the Department of History at Brown University where he is completing his dissertation, Crisis and Confidence: Reimagining New York City in the Late Twentieth Century.

Jonathan Soffer is Professor of History and Chair of the Department of Technology, Culture \& Society at the New York University Tandon School of Engineering. He is the author of Ed Koch and the Rebuilding of New York (New York: Columbia University Press, 2010) and currently working on a study of Tammany Hall and its relationship to New York's infrastructure. 


\title{
Introduction. After the Urban Crisis: New York and the Rise of Inequality
}

\author{
Themis Chronopoulos and Jonathan Soffer
}

It's important to keep rich people in the city of New York. Because they have all the money. And they have the entrepreneurs and we want them to invest. And they have two or three houses they can fly the coop at any time and therefore I have to be very respectful of their comfort in a sense. So when people said: 'Why are you fixing the roadbed on Park Avenue?' I said 'because if we don't fix it they're gonna leave. They pay a lot of rent. And if they think they're getting shafted and not attended to, and that all that we're going to spend money on is the poor, then they'll leave.'

\section{--former New York City mayor Edward I. Koch ${ }^{1}$}

Mayor Ed Koch's explanation of the class bias in service delivery during his administration illustrates the key theme of this section: policies that promoted New York as a place for the wealthy. This was not necessarily his goal. Koch justified better service delivery to the rich in order to retain its tax base as a precondition to making the city a better place for the middle class. He did his best to deliver by rebuilding the South Bronx and other devastated areas as affordable housing, as Themis Chronopoulos's article in this section illustrates.

Over time, Koch's promise of a middle class New York faded. In 2013, Mayor Michael Bloomberg summed up his policies designed to promote the city as a preserve of the rich, and dismissed concerns about income inequality and the increasingly rigid control of public space that he imposed: "If we could get every billionaire around the world to move here, it would be a godsend that would create a much bigger income gap," which, he argued, was good for the whole city, because it would raise its tax base. ${ }^{2}$

The shift from ideals of "socialism in one city" that predominated until the 1970s, to Koch's idealized "middle class" New York, to Bloomberg's twenty-first century vision of the city as a playground for the 1 percent, was over-determined by a larger shift in the world political economy of the 1970s and 1980s, toward increased income inequality and the de-politicization of economic management to make it less democratic. ${ }^{3}$

It is also important to remember that New York's troubles did not begin in the 1970s. As Thomas Sugrue has demonstrated, the "urban crises" of the 1970s in cities across America resulted in part from the complex interplay of structural and contingent local forces set in motion long before. Deindustrialization began in some cities as early as the 1920s. Pressures for political conformity, structural racism, and actively discriminatory housing policies throughout the postWorld War II period led to disinvestment in the urban core and subsidized racial segregation. These postwar policies created an urban crisis that curtailed revenues and services and created a cycle of decay that intensified population loss, raised crime rates, deepened poverty, ruined the built environment, and destroyed land values. ${ }^{4}$

All of the long term forces that Sugrue cites were to some degree present in New York City. A shrinking population and tax base, a consequence of federal housing policy subsidizing suburbanization, contributed to the city's inability to service its debts by 1975 . The city's creditors forced it into austerity programs that cut its operating budget and capital spending in ways that cost far more than they saved, and long delayed its recovery. Because of inequalities in the distribution of benefits by the city government, New York's wealthier citizens were partly 
exempted from paying the costs of cuts in city services. The burden of declining services fell most heavily on the rest of the city.

After 1960, the city's population was increasingly young, of color, unemployed, and poor. A decade of democratic initiatives in the Lindsay and Beame administrations helped and appealed to many of these new New Yorkers. But by the mid-1970s, the wealthiest taxpayers, bargaining with various factions of the Democratic Party, took more direct control of the city budget for nearly a decade, a process that has happened often enough in the city's history that the political scientist Martin Shefter has argued that it is cyclical. ${ }^{5}$ As Joshua Freeman has observed, financial elites used the fiscal crisis to dictate their political and social vision:

In the recession and the budget crisis, financial leaders saw an opportunity to undo the past, to restructure New York along lines more to their liking than those drawn by decades of liberalism and labor action. They wanted less and less costly government, fiscal probity, and the de-socialization of services and protections for the working class and the poor. They also wanted humbled municipal unions that no longer would enable government workers to have superior benefits and a less intense pace of work than private-sector workers. The banks had not been able to effect such a program during the post-World War II years, a testament to the strength of labor and its allies. But as the city began sliding toward insolvency, they saw a greater need and a greater possibility of carrying out their financial and social agenda. ${ }^{6}$

This market orientation was increasingly appealing to politicians of both parties. If the market made economic decisions that diminished their constituents' standard of living, then they would not have to take responsibility for the decline. ${ }^{7}$ Many New York politicians - Ed Koch is a good example - believed that markets would eventually create a New York City economy that was sustainable for the broad middle class.

Unfortunately, as Greta Krippner points out, market discipline did not make the economy more productive. Financialization, which Krippner defines as "the tendency for profit making in the economy to occur increasingly through financial channels rather than through productive activities," proved one of the principal drivers of class inequity during the 1980s, especially as it became linked to the expanding residential real estate market described in this section by Benjamin Holtzman. ${ }^{8}$ The process of financialization began when the Federal Reserve raised interest rates to unprecedented levels in the early 1980s — as high as 20 percent for the federal funds target rate to combat inflation, spiking unemployment and accelerating de-industrialization by making financial assets far more attractive than industrial properties. Financialization thus promoted credit expansion instead of the growth of production or wages, and increased income inequality. High interest rates attracted investors from around the world to the U.S. in general, and particularly to New York's banking, insurance, and real estate sectors, inflating financial assets. $^{9}$

Financialization was particularly consequential for New York. Finance and real estate towered over the deteriorated industrial sector, providing a greater proportion of New York's employment and tax receipts than ever. But there was a price. Finance capitalists, such as Secretary of the Treasury William Simon, who had profited from some of the New York City debt he later condemned, demanded deregulation and the reduction of public services and taxes that had limited income inequality before the $1980 \mathrm{~s}^{10}$

In the bleakness of austerity, financialization appeared to be New York City's salvation. ${ }^{11}$ Though it brought temporary relief to the city's budget after 1984, financialization exacerbated 
income inequality. In 1970 and 1998, the top 0.01 percent of earners made fifty times the average income; by 1998, that figure had increased to 250 times average income. ${ }^{12}$ In minority neighborhoods, the lack of waged jobs, the decline of welfare, and the new emphasis on entrepreneurship manifested in the expansion of the informal economy, from unlicensed day care to more violent businesses, such as the marketing of cocaine. ${ }^{13}$

The four articles that comprise this special section of the Journal of Urban History are part of a new and growing body of historical works about New York City since the 1970s that examine how New Yorkers coped with declining infrastructure, services, standards of living, and increasing inequality. ${ }^{14}$ They challenge the linear narratives of concepts such as neoliberalism, gentrification, public space, and law and order, and resistance.

Benjamin Holtzman in "'I am Not Co-Op!' The Struggle over Middle-Class Housing in 1970s New York" shows the extent to which the middle class of New York City rejected homeownership prior to the 1980s. Beginning in the 1960s, real estate agents and building owners proposed the conversion of rental properties into co-ops. They argued that tenants would be able to control their destinies by owning their properties. At that time, the state regulated almost all of the properties proposed for conversion from rentals into co-ops. Tenants who benefitted from these rent regulations opposed apartment conversions and the uncertainty that homeownership in a declining city entailed. Indeed, as they predicted, the proposed conversions resulted in a shift of costs and responsibilities from the city and landlords to residents and the inflation of the housing market.

As New York's fortunes improved, an increasing number of tenants accepted these conversions, largely because landlords offered them heavily discounted insider prices. Existing middle-income apartment buyers benefited, since they could take advantage of rising real estate values and the easy availability of mortgage credit, eventually selling their property for a great profit. However, rising prices meant that many of formerly affordable units ended up in the hands of upper income individuals. This homeownership trend may have attracted affluent people from around the world to New York, but has also made it difficult for many middle class people to remain in the city, because they are forced to pay much higher housing costs. While the number of rentals has remained stable since 1980, the number of owned units has increased by 51.6 percent (Figure 1), even as the population of the city has increased by nearly 20 percent. 


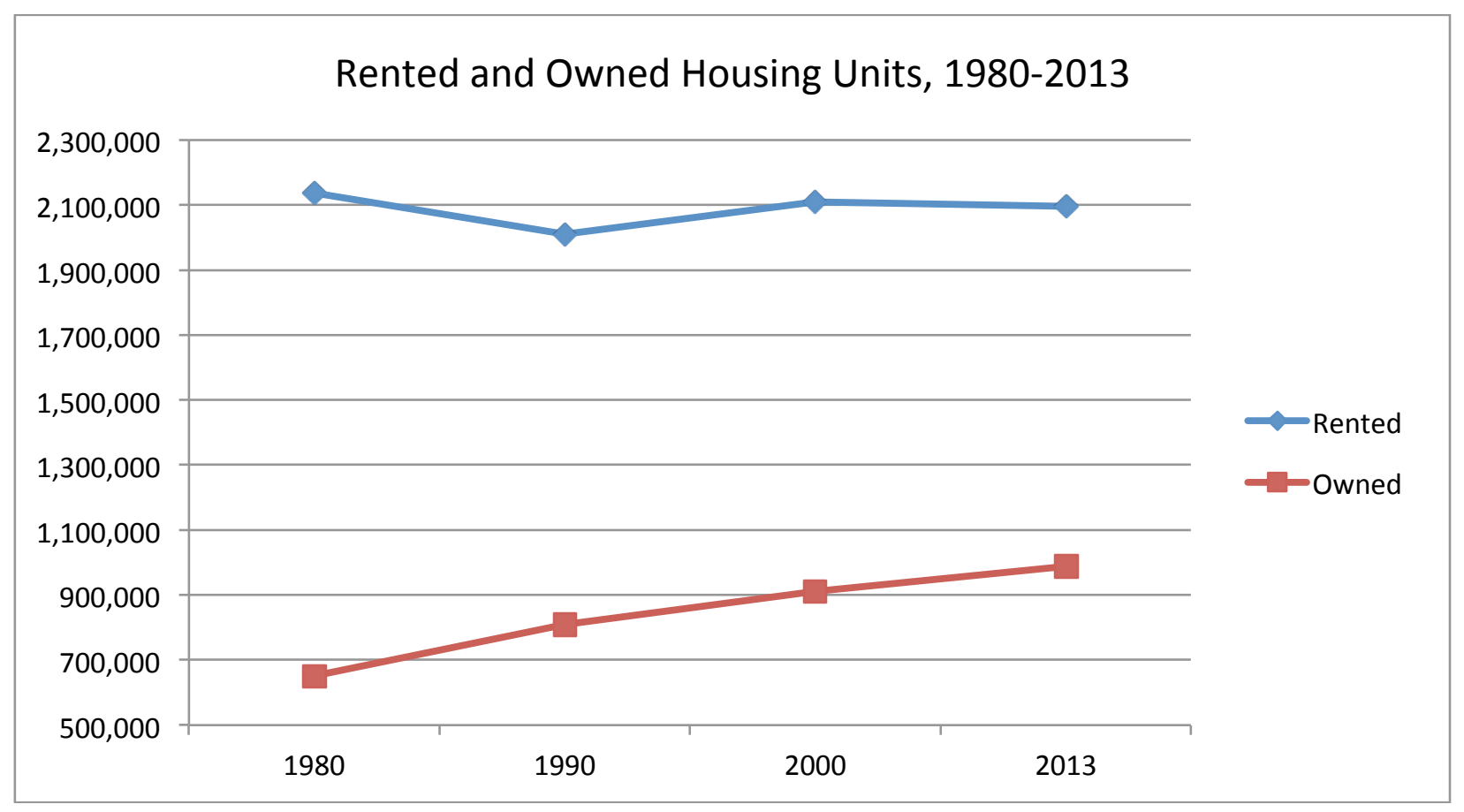

Figure 1. Number of rented and owned housing units in New York City, 1980-2013. Source: U.S. Census Bureau surveys of 1970-2000, and the One-Year American Community Survey of 2013.

Holtzman's article highlights the role of ordinary citizens in resisting conversions that primarily benefited landlords, and negotiating a change in the system that made conversions much more attractive for tenants. The scholarship on the growth of conservatism and the shift toward an increasingly commodified political economy after the 1960s in the United States has focused overwhelmingly on conservative politicians, free market advocates, and pro-market officials. Holzman corrects this interpretation by demonstrating that conservatives were not the only actors in changing the housing market. He describes the successful resistance to the neoliberal homeownership program by tenants, who were able to delay for more than a decade the conversion of a large portion of the city's housing market to individual home ownership until they received significantly better terms. ${ }^{15}$

In "“A Shelter Can Tip the Scales Sometimes": Disinvestment, Gentrification, and the Neighborhood Politics of Homelessness in 1980s New York City," Ariel Eisenberg discusses how various communities in New York resisted the city government's efforts to open homeless shelters in their neighborhoods. ${ }^{16}$ The "Not in My Backyard" (NIMBY) movements forced the city government to open such centers without neighborhood consultation and by surprise. Activists in low income neighborhoods opposed shelters for reasons that were different from those of more affluent areas - arguing that the practice exacerbated economic inequality.

Residents of Harlem and East New York, who were fighting for neighborhood survival after the wounds inflicted by the austerity regime, argued that the city was disproportionately opening shelters in low income areas that lacked the resources to deal with their possible negative effects. The city administration was not providing adequate services to their neighborhoods and they did not trust that this would be any different when it came to the needs of the homeless. Residents of the more affluent Upper West Side also opposed the opening of a shelter there, though their opposition had more to do with exclusivity and property values. 
As Eisenberg shows, homelessness became increasingly a marker of racial difference, as the 1980s progressed. As the total number of homeless people increased, homelessness declined among whites, but rose among people of color, especially black males. ${ }^{17}$ This racialized image of made it easier for Mayor Giuliani to intensify police control of homeless people in public space. ${ }^{18}$ The removal of the homeless to shelters did not solve either their problems or the city's: there are more homeless people in shelters in New York City today than ever before (Figure 2 ). ${ }^{19}$ The police, however, were not the only agency ordering public space in the late twentiethcentury city.

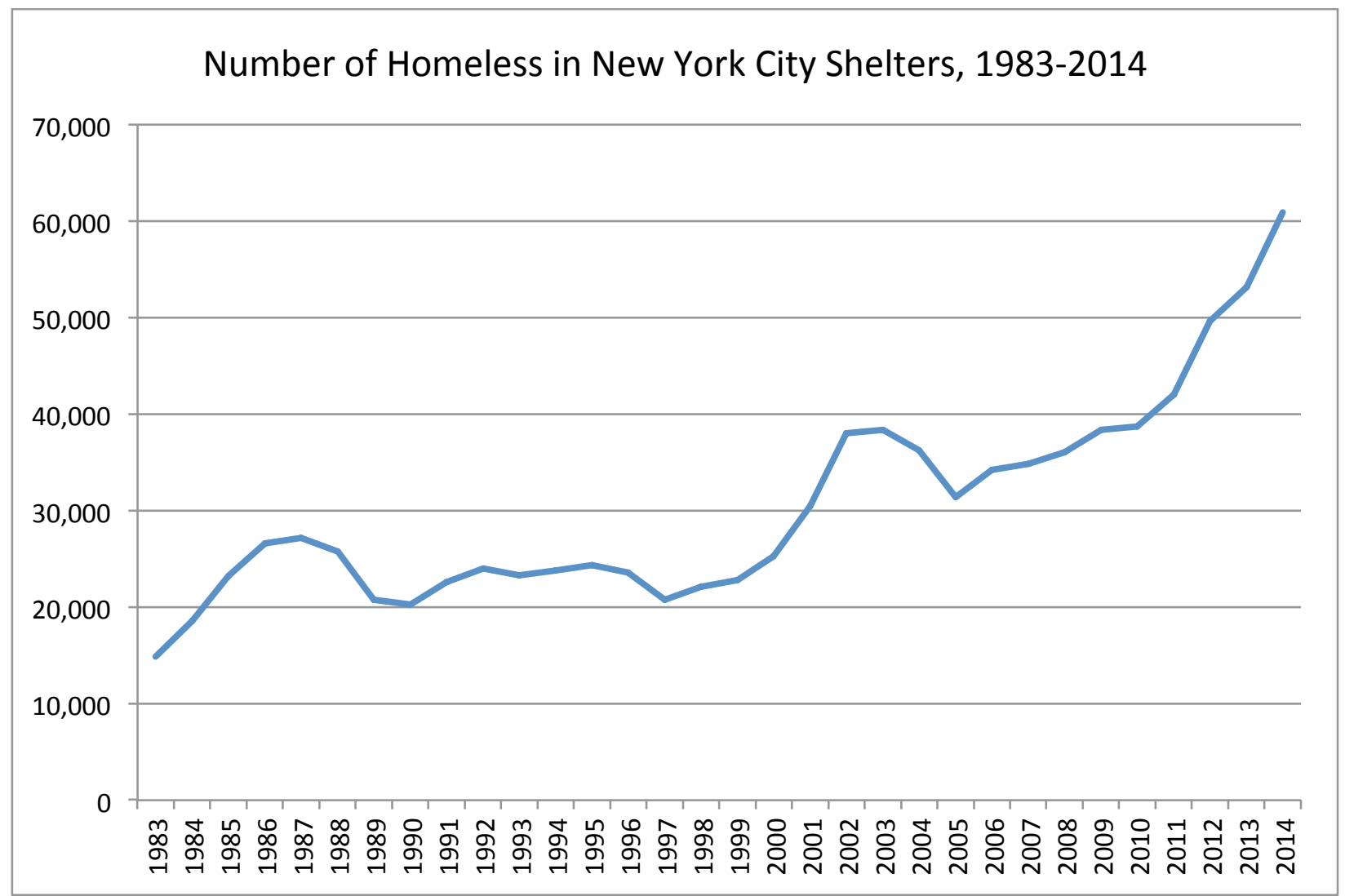

Figure 2. Number of homeless people in New York City shelters, 1983-2014. Source: The Coalition for the Homeless, 2015.

Reiko Hillyer's article, “The Guardian Angels: Law and Order and Citizen Policing in New York City" looks at how poor people of color, often seen as the victims of the punitive turn in American society, responded to the decline in police services and the increase in crime that marked the 1970s and 1980s. The focus of the article is on the Guardian Angels, a group of working class white, black and Latino youths who began to patrol the subways in 1979 so that they could dissuade criminals from operating there. Hillyer problematizes the "law and order" narrative, which is usually viewed as a white conservative or neoconservative movement that criminalizes low income populations of color. ${ }^{20}$

Crime rates in New York City rose substantially in the mid-1960s and remained high (Figure 3) despite a series of city administrations that made crime-fighting their priority. During the 1970s fiscal crisis, the reduction of the police force by about one-third, partly through layoffs, 
and cuts in the capital budget, leaving police to work in stations, patrol cars and with equipment that was often broken and seldom repaired, compromised morale and made law enforcement sporadic. Austerity at the NYPD came on top of previous revelations of widespread police corruption by the Knapp Commission in 1972, which also deteriorated both morale and public confidence in the department. Austerity and corruption problems worsened a situation where the legal underpinnings of public order maintenance had already been radically changed by the US Supreme Court decision in Papachristou v. Jacksonville (1972), which invalidated most disorderly conduct statutes that had allowed police to arrest people on the basis of their status, rather than on the basis of an observed criminal act. ${ }^{21}$

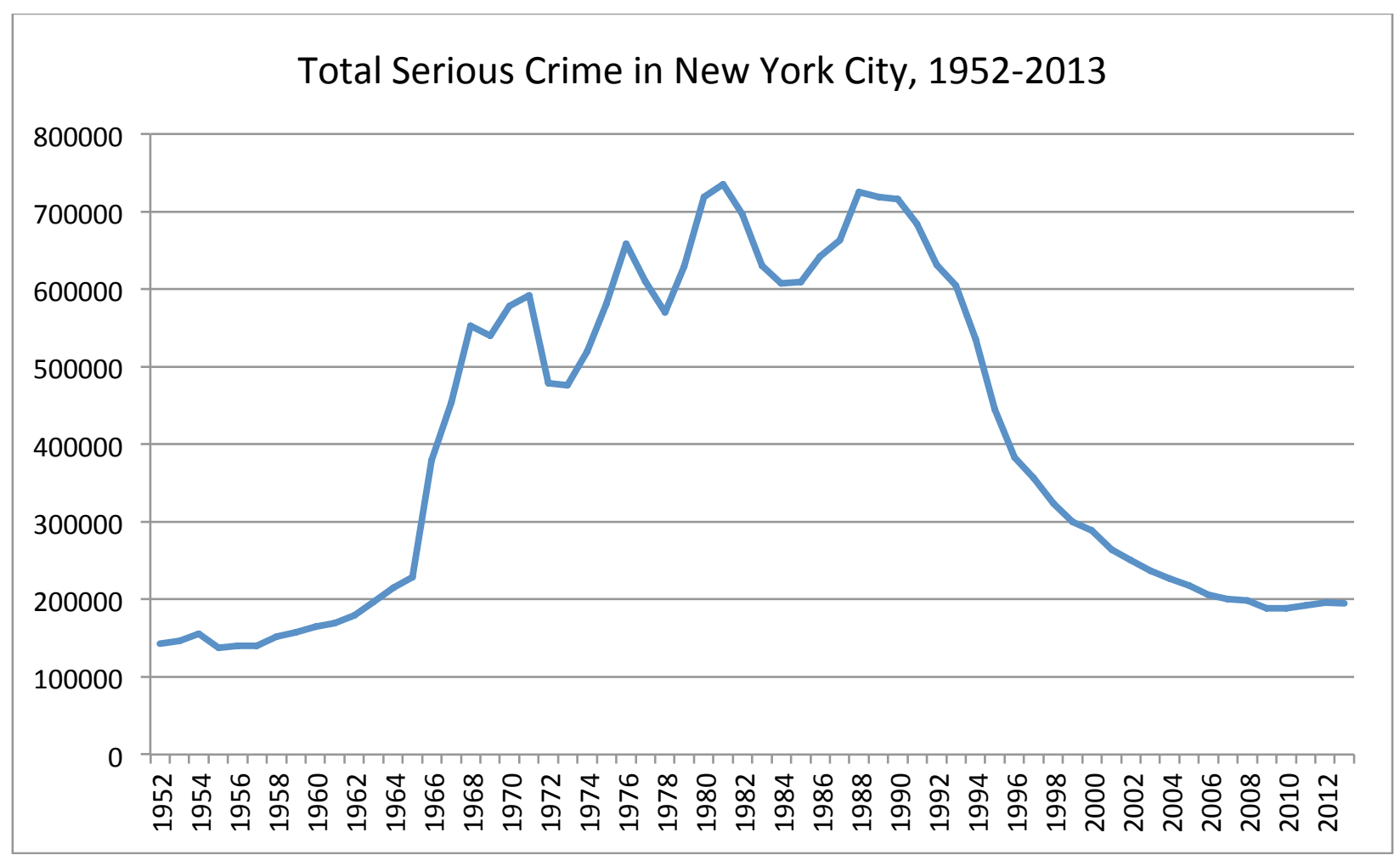

Figure 3. Total number of serious crime known by the New York Police Department, 1952-2013. This category is the sum of murders, non-negligent manslaughters, forcible rapes, robberies, aggravated assaults, burglaries, larcenies and thefts, and motor vehicle thefts. Source: The Uniform Crime Reports of the Federal Bureau of Investigation, 1952-2013.

The formation of the Guardian Angels represented a response to this perfect storm of police inefficiency, especially in low income minority communities whose residents had suffered disproportionately from criminal activities and could not count on adequate police protection in light of the city's service delivery priorities. ${ }^{22}$ Hillyer recounts how the Guardian Angels appeared in force to regulate behavior and chase individuals out of the neighborhoods they were patrolling based on their appearance and status - actions that the Supreme Court had forbidden to the police. In Times Square, for example, the Guardian Angels used heavy-handed tactics against poor people in public space while getting praised by local businesspeople for keeping the area "clean." Hillyer shows how austerity led ordinary citizens to lose faith in government institutions, 
seeming to justify conservative narratives about law-and-order, volunteerism, and even vigilantism.

Few areas that have been affected as heavily by the urban crisis in the United States as the South Bronx. There are even fewer areas that have been completely rebuilt and revived. In "The Rebuilding of the South Bronx after the Fiscal Crisis," Themis Chronopoulos explores an important public policy accomplishment.

The rebuilding of the South Bronx defies linear narratives. The Koch Administration frequently employed public-private partnerships, which represent some of the most important features of urban neoliberalism, in the revitalization of the South Bronx. Community organizations that had been rebuilding areas in the South Bronx in the 1970s and the 1980s were required to conform to the requirements of the market, if they were to continue participating in urban development. However, the building of housing for low- and moderate-income people was also a way for Bronxites to mitigate the devastating action of both the long term structural forces that disinvested in the Bronx and the cuts in fire department services that led to its incineration. ${ }^{23}$ Despite the crucial role of private groups, housing units were built with public subsidies and regulated by government agencies. The city government promoted creative financing, often facilitated by non-profit, non-government organizations managed by accomplished businesspeople. The city's success in building housing for so many people performing lowpaying but essential jobs, has contributed to the making of a more vibrant urban economy, even if these same people are not necessarily the ones benefitting most from New York's economic dynamism.

Long term structural inequalities based on race and class, combined with the changes in the world system of political economy after 1970s that accelerated income and wealth inequality, tore the social and physical fabric of New York. The progenitors of austerity in the 1970s and 1980s arguably sacrificed thousands of lives for the good of New York's bondholders, establishing what amounted a temporary dictatorship of the city's bourgeoisie, albeit with union workers' money and participation. The four essays in this section demonstrate that the political and ideological victory of finance capital was, however, far from complete. Each author illustrates the complexity of citizen and governmental resistances and adaptations to neoliberalism. Those movements were as often conservative as progressive. They represent a sampling of ordinary New Yorkers' successes and failures in re-negotiating the social contract in a period of increasing inequality. 


\section{Notes}

${ }^{1}$ Edward I. Koch, Interview with Jonathan Soffer, C-SPAN TV October 26, 2010, http://www.c-span.org/video/?296478-1/book-discussion-ed-koch-rebuilding-new-yorkcitybillionaire/\#ixzz3iVSIzObX.

2 Jill Colvin, "Mayor Wants City to have Every Billionaire," Observer, September 20, 2013, http://observer.com/2013/09/mayor-bloomberg-wants-city-to-have-every-billionaire/

${ }^{3}$ Greta R. Krippner, Capitalizing on Crisis: The Political Origins of the Rise of Finance (Cambridge: Harvard University Press, 2011), 3, 149.

${ }^{4}$ Thomas J. Sugrue, The Origins of the Urban Crisis: Race and Inequality in Postwar Detroit (Princeton: Princeton University Press, 1993), 5-6, 11. For additional literature on the processes of the postwar urban crisis, see Jon C. Teaford, The Rough Road to Renaissance: Urban Revitalization in America, 1940-1985 (Baltimore: Johns Hopkins University Press, 1990); Robert A. Beauregard, Voices of Decline: The Postwar Fate of US Cities (Cambridge: Blackwell, 1993);); Roger Biles, The Fate of Cities: Urban America and the Federal Government, 19452000 (Lawrence: University Press of Kansas, 2011); Kenneth T. Jackson, Crabgrass Frontier: The Suburbanization of the United States (New York: Oxford University Press, 1985).

${ }^{5}$ Martin Shefter, Political Crisis, Fiscal Crisis: The Collapse and Revival of New York City (New York: Basic Books, 1985), xi-xiv. The Swallowtail "reformers" who took power in the wake of the collapse of the Tweed Ring are one of the best examples. See David C. Hammack, Power and Society: Greater New York at the Turn of the Century (New York: Russell Sage Foundation, 1982), 132.

${ }^{6}$ Freeman, Working Class New York, 258.

${ }^{7}$ Krippner, Capitalizing on Crisis, 2.

${ }^{8}$ Krippner, Capitalizing on Crisis, 3.

${ }^{9}$ Krippner, Capitalizing on Crisis, 87.

${ }^{10}$ See Kimberly Phillips-Fein, Invisible Hands: The Making of the Conservative Movement from the New Deal to Reagan (New York: Norton, 2009), xi, 166-211, 245.

${ }^{11}$ Krippner, Capitalizing on Crisis, 56, 67.

12 Thomas Piketty and Emmanuel Saez, "Income Inequality in the United States 1913-1998" NBER Working Paper 8467, http://www.nber.org/papers/w8467, 10; Thomas Piketty, Capital in the Twenty-First Century trans. Arthur Goldhammer, (Cambridge: Harvard University Press, 2014), 247, 302-7. 
${ }^{13}$ Soffer, Ed Koch and the Rebuilding of New York, 338-44. See Fritz Umbach, The Last Neighborhood Cops: The Rise and Fall of Community Policing in New York Public Housing, (New Brunswick: Rutgers University Press, 2010), 88-90.

${ }^{14}$ Recent historical studies that at least partially examine the late twentieth century in New York City include the following: Nicole Marwell, Bargaining for Brooklyn: Community Organizations in the Entrepreneurial City (Chicago: University of Chicago Press, 2007); Jesse HoffnungGarskof, A Tale of Two Cities: New York and Santo Domingo After 1950 (Princeton: Princeton University Press, 2008); Miriam Greenberg, Branding New York: How A City in Crisis was Sold to the World (New York: Routledge, 2008); Nicolas Dagen Bloom, Public Housing That Worked: New York in the Twentieth Century (Philadelphia: University of Pennsylvania Press, 2008); Soffer, Ed Koch and the Rebuilding of New York City (2010); Themis Chronopoulos, Spatial Regulation in New York City: From Urban Renewal to Zero Tolerance (New York: Routledge, 2011); Ella Howard, Homeless: Poverty and Place in Urban America (Philadelphia: University of Pennsylvania Press, 2013); Sonia Song-Ha Lee, Building a Latino Civil Rights Movement: Puerto Ricans, African Americans and the Pursuit of Racial Justice in New York City (Chapel Hill: University of North Carolina Press, 2014).

15 The arguments made in this article are part of Benjamin Holtzman, "Crisis and Confidence: Reimagining New York City in the Late Twentieth Century,” (Ph.D. Diss. Brown University, forthcoming).

${ }^{16}$ Some of the arguments made here can be seen in Ariel Eisenberg, "Save Our Streets and Shelter Our Homeless': The New York City Homeless Crisis in the 1980s," (Ph.D. Diss. University of Wisconsin, Madison, 2015).

${ }^{17}$ Michelle Alexander, The New Jim Crow: Mass Incarceration in the Age of Colorblindness (New York: New Press, 2010); Khalil Gibran Muhammad, The Condemnation of Blackness: Race, Crime, and the Making of Modern Urban America (Cambridge: Harvard University Press, 2011); Mark Anthony Neal, Looking for Leroy: Illegible Black Masculinities (New York: New York University Press, 2013).

${ }^{18}$ Chronopoulos, Spatial Regulation in New York City, 147-80.

19 The number of homeless people not using shelters is unknown, because the city government has never taken comprehensive counts.

${ }^{20}$ See, for example, Michael W. Flamm, Law and Order : Street Crime, Civil Unrest, and the Crisis of Liberalism in the 1960s (New York: Columbia University Press, 2005), 1-6, which emphasizes the agency of white conservatives in spreading the slogan of "law and order." For recent work on the agency of working and middle class African American leaders in promoting draconian incarceration policies, and the complexity of African American politics in this period, see Michael Javen Fortner, Black Silent Majority: The Rockefeller Drug Laws and the Politics of Punishment (Cambridge: Harvard University Press, 2015), x, xi, 14. 
${ }^{21}$ Soffer, Ed Koch and the Rebuilding of New York City, 352, 271, 284.

${ }^{22}$ Eric C. Schneider, Smack: Heroin and the American City (Philadelphia: University of Pennsylvania Press, 2008); Marilynn Johnson, Street Justice: A History of Police Violence in New York City (Boston: Beacon Press, 2003); Michael F. Armstrong, They Wished They Were Honest: The Knapp Commission and New York City Police Corruption (New York: Columbia University Press, 2012), Themis Chronopoulos, "Police Misconduct, Community Opposition, and Urban Governance in New York City, 1945-1965," Journal of Urban History (2015).

${ }^{23}$ Joe Flood, The Fires: How a Computer Formula, Big Ideas, and the Best of Intentions Burned Down New York City-and Determined the Future of Cities (New York: Riverhead, 2010), 246. 


\title{
"I am Not Co-Op!" \\ The Struggle over Middle-Class Housing in 1970s New York
}

Benjamin Holtzman

\begin{abstract}
In 1970s New York, apartment ownership became fraught terrain for competing ideas of how best to secure the city's future. Landlords and major real estate associations posited that New York could stem the exodus of middle-income residents by creating greater opportunities for homeownership in a city that had long been dominated overwhelmingly by renters. To do so, they proposed converting middle-income rental housing into cooperatives, a process that would also enable former landlords to profit handsomely. Tenants, however, widely rejected apartment ownership, preferring the security of rent-regulated housing. This article traces the ensuing struggles between tenants, the real estate industry, and city officials over the nature of moderate and middle-income housing in New York. The eventual success of the real estate industry enabled cooperative conversions to expand dramatically in the 1980s. This process helped to transform the city by underwriting a momentous turnaround in the real estate market, while signaling a larger embrace of market deregulation.
\end{abstract}

Acknowledgments: I would like to thank Anne Gray Fischer, Sara Matthiesen, Kimberly Phillips-Fein, Lindsay Schakenbach Regele, Elizabeth Searcy, and Samuel Zipp for their comments on early versions of this article. I am particularly indebted to Robert Self for his feedback. I am also very grateful to Themis Chronopoulos and Jonathan Soffer for their comments.

Biography: Benjamin Holtzman is a historian trained in the intersections of political, social, and economic histories of the twentieth century, with particular focus on politics, capitalism, cities and suburbs, social movements, and race. His research has appeared in Space and Culture, Radical Society, and several edited collections. He is a Ph.D. candidate in the Department of History at Brown University where he is completing his dissertation, Crisis and Confidence: Reimagining New York City in the Late Twentieth Century. 


\section{Introduction}

Rexford E. Tompkins was deeply concerned about the future of New York City in the late 1960s. Tompkins, a major figure in the city's real estate industry, was President of the Real Estate Board of New York (REBNY), the industry's most important trade organization, and head of the leading firm, Brown Harris Stevens. From his perch atop the profession, Tompkins worried openly about the ongoing "housing decay and disaster in our city."1 Despite a seemingly robust economy, Tompkins's fears represented well the concerns of the real estate industry. The city appeared to be losing its desirability to the middle class. While the surrounding suburbs were burgeoning with fledgling homeowners, who were aided by generous federal subsidies, New York remained a city of renters, bucking the powerful postwar trend toward homeownership. ${ }^{2}$ Dominated by multi-family rental buildings and with new construction at a standstill, the city offered few ownership opportunities for the middle-class populations piling into the suburbs. ${ }^{3}$

Just as alarming to Tompkins and his colleagues was the declining condition of the housing stock. Landlords unable to make sufficient profits in low-income areas were beginning to walk away in large numbers from their real estate holdings. ${ }^{4}$ But prominent real estate figures like Tompkins expressed greater concern with the decline of the housing stock in middle-income neighborhoods, which they believed only exacerbated the middle-class exodus. Real estate men blamed the city's strong rent protection laws that limited landlord capital for continued upkeep. Tompkins heralded the virtues of a "free market" system that he felt would allow landlords to raise rents, adequately care for their buildings, and increase their profits, but he and his colleagues had limited means to repeal controls in a city dominated by rent-protected tenants. ${ }^{5}$

Along with other prominent real estate figures, Tompkins championed a creative solution that would alleviate both of these anxiety-producing conditions: converting rental buildings into cooperatives. "The fundamental drive toward home ownership," Tompkins believed, "can only be satisfied in an urban economy through co-op ownership." Additionally, owners seeking to convert their buildings would underwrite repairs and improvements to induce tenants into assuming ownership, as the potential sale created a financial incentive to do so. The conversion of rental housing thus seemed to solve the two perilous conditions pulling the city toward an economic and housing crisis as the tax base and housing stock eroded. Conversions, Tompkins declared, were "the only genuine hope for any salvation for the city's housing supply.",

Real estate boosters like Tompkins helped launch a campaign in the late 1960s to convince city dwellers that converting rental buildings to cooperatives would benefit them, their neighbors, and the city as a whole. As they saw it, conversions would keep the middle-class in the city. Landlords - from owners of single buildings to real estate barons - overwhelmingly supported the idea of selling rental apartments to tenants, particularly because conversions were a profitable means to escape the extensive rent regulation system. Many prominent officials, housing experts, and civic leaders also believed that converting rental buildings would improve the housing stock and benefit all involved: landlords would profit handsomely, residents would be able to own their own homes, and the city would stabilize property and income tax revenue. For example, Herman Glaser, chairman of the recently-formed consumer advocacy group New York Council for Civic Affairs, proclaimed that "cooperative ownership represents a valid and valuable approach to the preservation of good housing and a way of encouraging middle-class families to remain in the city." Greater homeownership opportunities might also induce some of the over 600,000 people who commuted from the suburbs to take up residence within the city. ${ }^{9}$

Many tenants disagreed. When Louis Smadbeck, the president of the realty concern William A. White \& Sons, asked tenants at a 1972 public hearing, "Doesn't every New Yorker 
really want to own a co-op?," his question provoked only "a chorus of noes."10 Tenants saw few benefits to purchasing their apartments, favoring the familiarity and security of remaining renters.

For over a decade, as New York descended toward an economic crisis and near bankruptcy in the 1970s, heated battles between tenants and real estate boosters over conversions raged throughout the city. These contests provide a powerful counter narrative to the postwar period being one in which Americans clamored for homeownership. In New York, and in a handful of other cities, tenants fought to protect rental housing. I argue that "ownership" became fraught terrain involving two competing ideas of how best to secure the city's future. On one side were landlords, real estate organizations like REBNY, and industry leaders like Tompkins, who saw conversions as an opportunity to dismantle rent regulations and increase profits. Joining them was a number of politicians, heads of civic associations, and business leaders who viewed increased homeownership as the means to improve the housing stock and expand middle-class populations. On the other side were tenants who organized within and across buildings threatened by conversion. They argued that conversions would eradicate the middle class by decimating the rent regulations that kept housing costs within its reach.

New York's middle-class tenants generally rejected the opportunity to own their apartments for numerous reasons. To many tenants, homeownership was simply unfamiliar; having lived without it, they saw it promising few direct personal benefits. Additionally, because laws protected many residents from significant rent increases, fixed-rate mortgage payments were less of an obvious advantage, especially when coupled to a sizeable down payment. Others felt little assurance that their investments would grow, a not illogical sentiment given that cooperative unit prices fell steeply in the late 1960s and that the city's future looked precarious to many city dwellers. Many tenants also claimed that they or their neighbors could not afford to purchase their apartments and rejected any proposal that forced the choice: buy or vacate. For this complicated but understandable set of reasons, tenants banded together to block the proposed conversion of their buildings and, increasingly, to stop conversions from spreading across the city. Their cause was supported by New York law, which required that a specific percentage of existing tenants in a building (35 percent in 1968) had to agree to purchase their apartment in order for conversion to receive state approval.

By the early 1980s, however, renters' sentiment about conversions began to shift. As tenants won reforms to the conversion process, as real estate prices began to rise, and as a growing number of fledgling middle-class cooperative owners began to encourage ownership through new organizations and publications, what began as a movement opposing conversions became one that aimed to secure for tenants the most lucrative conversion deals possible. This changing attitude about ownership enabled conversions to expand dramatically in the 1980s, transforming the city by underwriting a momentous turnaround in the real estate market and signaling a larger embrace of market deregulation.

\section{Promoting Homeownership in the City of Renters}

Leading figures of New York real estate like Tompkins were not foolish for thinking that tenants might find conversions attractive. The list of potential benefits was substantial. In addition to the opportunity to own one's home, federal and state laws and city ordinances offered cooperative owners tax deductions similar to those available for single-family homes in suburban areas. ${ }^{11}$ Though much of New York's rental stock was protected from substantive rent increases by city regulations, some tenants in rent-regulated buildings believed that ownership would enable them to improve their building more than the landlord had been able or willing to do. 
Conversions protected tenants in de-controlled apartments against unpredictable rent increases. Real estate representatives commonly noted such advantages. Smadbeck, for example, took to the Times op-ed pages to implore tenants to "grasp fully the benefits of ownership, including the tax advantage and the direct control of the management of their building." 12

Conversions, however, promised even greater gains for the real estate industry. Major industry figures and real estate organizations who championed conversions believed increasing homeownership opportunities would benefit all residents by improving New York's long-term health. But they were principally compelled to act because of the concern that their industry faced the gravest threat as a continued middle-class exodus weakened the economic stability of the city and its real estate. Additionally, both large operators and individual owners of rental housing overwhelmingly supported conversions because they promised enormous profits. Selling off a building through sales of individual units to tenants produced far greater sums - generally three to four times more in the early 1970 s - than selling one's building to another landlord. ${ }^{13}$

Conversions particularly appealed to owners of rent-controlled properties, which comprised 77 percent of the rental stock in $1960 .{ }^{14}$ Perhaps no issue provoked the ire of landlords quite like rent control, which owners viewed as artificially constraining profits by significantly restricting rent increases. Federal officials had introduced rent regulations as part of price and inflation control measures during World War II, but they continued into the postwar decades in New York as a result of organizing by the city's strong tenant movement. Landlords had by the 1960s formed various organizations whose principal aim was doing away with rent control, but none became a sufficient counterweight to the collective political strength of millions of rent-protected tenants. Conversions thus seemed at first to offer landlords a politically tenable and highly profitable escape from the limited earnings of rent-regulated housing.

The real estate industry actively encouraged the spread of conversions through its major trade organization. REBNY offered landlords educational seminars on "how to co-op your rent controlled apartment house" and prophesized to political officials about the fortunes conversions would bring. ${ }^{15}$ Conversions allowed landlords to sell their buildings "at a fair prices to the tenants," Rexford Tompkins declared. ${ }^{16}$ They were, he told members of the City Council in 1969, the "only possible escape" from urban ruin. ${ }^{17}$

Though rent-controlled tenants were slow to accept conversions, boosters like REBNY convinced Mayor John Lindsay of its benefits. Lindsay took a keen interest in promoting conversions by the late 1960s, particularly in rent-controlled buildings. Lindsay's head of the Housing and Development Administration (HDA), Jason Nathan, had commissioned several studies on rent controls. ${ }^{18}$ These studies blamed the provisions for landlord abandonment in lowincome neighborhoods and for insufficient upkeep in moderate and middle-income areas. ${ }^{19}$ Along with growing pressure from landlords who were becoming "more organized" and "more adamant," these studies convinced Lindsay and key members of his administration that rent controls were the leading cause of building abandonment and that they would soon cause the decline of middle-class neighborhoods as well. ${ }^{20}$

With millions of residents protected by rent control, Lindsay recognized that it was politically impossible to remove controls in a single stroke. He instead looked for ways to reduce their supposedly harmful effects. ${ }^{21}$ Administration officials, including Nathan, believed that converting rent controlled buildings to cooperatives was a viable means to do so. Conversions, one HDA report optimistically declared, would satisfy all parties: rent controlled tenants who were "dissatisfied with building maintenance and deterioration," landlords who "would like to be absolved of the problems of managing property under the provisions of rent control," and city 
officials who sought low-cost means to improve housing. ${ }^{22}$ Lindsay administration officials also hoped that through increasing homeownership, conversions might stabilize the population and "contribute toward keeping the middle class in the city.",23

Lindsay administration officials, however, struggled to find ways to promote conversions in middle-income areas. This changed with the passage of the city's Rent Stabilization law in 1969. Rent stabilization resulted from years of bitter debate between real estate and tenant advocates over the growing number of apartments that were unprotected from rent regulations (principally those build after 1947), which largely housed middle-class tenants. Many tenant advocates applauded the law because it instituted rent regulations for these 400,000 units, even if stabilized apartments faced much more significant yearly increases than rent controlled units. Landlords, however, quickly became alarmed that the law would restrict profits on these newly regulated buildings, leading conversion proposals to spike. ${ }^{24}$ Additionally, the Mayor's office and City Council members had included an initially little-noticed provision that lowered the number of existing tenants needed to agree to purchase their apartment from 35 percent to 15 percent for a conversion to be allowed to proceed in a rent stabilized building, greatly increasing the likelihood of success.

The rent stabilization law kick-started a battle over conversions that would last for well over a decade. ${ }^{25}$ Although Mayor Lindsay and the real estate industry had hoped that city dwellers would welcome the opportunity to own their apartments, tenants responded to the increasing number of conversion proposals with outrage and fear. Rita Savoy, for example, an elderly tenant of 250 West $94^{\text {th }}$ Street, wrote to New York Attorney General, Louis Lefkowitz, in a "desperate situation." A number of "wealthy tenants" of her rent regulated building supported a conversion to a cooperative. The building, Savoy acknowledged, was in "poor shape" and the conversion would result in needed improvements to the pipe system, roof, and building interior. These seemed to be the exact circumstances conversion boosters pointed to in making their case about the benefits of conversions. But the conversion would make monthly maintenance costs in the cooperative "out of the question" for her and many of her neighbors, among whom were "social Security recipients, city pensioners, widows, invalids in chairs .... refugees from Nazzi [sic] concentration camps, and some, like myself, although past seventy continue working to meet ends." She feared that she and her neighbors would have to leave her home. "Why should rich tenants," Savoy wrote, "have the right to throw out those who have no money?" The new law made it possible for 15 percent of a building's residents to force the conversion of the entire building, leaving those who did not purchase their apartment open to eviction proceedings. Savoy's fear was understandable. ${ }^{26}$

With the provision supported by the City Council and Mayor, tenants like Savoy reached out to Lefkowitz because of New York's unique arrangement in which the state's Attorney General oversaw cooperative and condominium offerings. ${ }^{27}$ Lefkowitz and Assistant Attorney General David Clurman, recognized cooperatives as potentially beneficial to tenants and the city but saw themselves as public advocates responsible for protecting tenants in the process.

Lefkowitz, a liberal Republican like Lindsay, was widely admired, winning each of his elections handily since 1958, and much of his popularity rested on his strong reputation as a consumer advocate. Neither Lefkowitz nor Clurman believed that requiring only 15 percent of residents to approve a conversion afforded ample protection for tenants.

Taking matters into their own hands, Lefkowitz and Clurman refused to approve any conversions proposed for a rent stabilized building unless the owner received the endorsement of 35 percent of tenants. Lefkowitz wrote to Mayor Lindsay and the City Council President that the 
reduction to 15 percent "represents a clear danger to the public interest." 28 Lefkowitz's actions sparked several supportive Times articles, no doubt embarrassing the Mayor who personally intervened, imploring Lefkowitz to see that the city's future required greater homeownership. ${ }^{29}$ But the Attorney General would not budge. With Lefkowitz's office refusing to approve conversions, the City Council and the Mayor backed down, agreeing to establish a 35 percent threshold in rent stabilized buildings. ${ }^{30}$

The struggle over the rent stabilization provision was representative of the broader awakening of tenant opposition to conversions at the end of the 1960s. As landlords proposed conversion plans for an increasing number of middle-class buildings, tenants began to organize, first in their buildings and then citywide. Rejecting the notion that conversions would enable the city to retain a healthy middle-class population, these residents offered themselves as examples of how conversions would in fact force the middle class out of the city.

\section{Middle Class Opposition to Cooperative Conversions}

Though tenants saw Clurman and Lefkowitz as allies, city residents opposing conversions did not rely on political officials alone. And while the Attorney General's office sought to make the conversion processes fairer for tenants, there was a growing sentiment among some tenants that conversions should instead be stopped entirely.

The Tenants Against Cooperative Conversion (TACC), formed in 1969, led this effort. "There exists a powerful Real Estate lobby," the notes from one early TACC meeting observed. "Tenants must all join together to create a stronger lobby." 31 The group called for a variety of provisions that, if enacted, would effectively bring an end to nearly all conversions in the city. ${ }^{32}$

TACC grew swiftly. Forty-four buildings facing or expecting conversion plans unanimously accepted its platform within a few weeks. ${ }^{33}$ These buildings were primarily on the Upper East and West Sides of Manhattan, where conversion proposals first proliferated before spreading quickly in the early 1970s to other parts of Manhattan and, more steadily, to Brooklyn and Queens. The group organized protests at politicians' offices and spoke out at hearings for legislation that affected conversions. "Stop Cooperative Coercion Now!," one of the group's early fliers proclaimed bluntly. It continued: "WE MUST SHOW THE POLITICIANS THAT WE MEAN BUSINESS."34

Though TACC had begun to successfully mobilize tenants for protests and similar actions, most residents struggled against conversions by organizing tenant associations within individual buildings, often doing so only after their landlord proposed a conversion. For example, residents at Park Terrace Gardens in Inwood, the northernmost neighborhood in Manhattan, formed a tenants' association to block their landlord's proposed conversion. When the landlord put up a large sign advertising cooperative apartments for sale, many tenants responded with smaller signs in windows throughout the complex that asserted: "I AM NOT CO-OP."35

Tenants like those in Park Terrace Gardens opposed conversions for a multitude of reasons. In 1970, it was by no means assured that cooperatives would increase in value. Following a remarkable growth in prices between 1967 and 1968, cooperative values declined precipitously the following year, as a national recession and steep fall in the stock market dragged housing values downward. Tenants also rejected the claim by boosters that "co-oping" would help to stabilize middle-class neighborhoods. As Park Terrace tenants observed, "our houses are not isolated from the socio-economic problems of our local community or the overall urban community." 36 Neighborhood parks "are no longer maintained, policed, or cleaned as they were ten years ago" and "parents no longer look forward eagerly to having their children attend 
the local schools." In the context of widespread deterioration of city services, they wondered if homeownership represented the boon to residents claimed by the real estate boosters.

Tenants also rejected co-oping out of concerns for their neighbors who might be forced to move if they could not afford to purchase their apartments. Co-oping was not simply unsound "from a financial standpoint, but also from an ethical and moral point of view," as Park Terrace residents noted, echoing many tenants facing conversions. What would happen to the tenants who could not afford to buy, particularly elderly tenants, widows, and younger tenants? "We would never speculate on the misery of others," one tenant declared. ${ }^{37}$ The city's vacancy rate in 1970 was 1.5 percent, a frightening number to tenants needing to search for a new apartment. ${ }^{38}$

Concerns about affordability were not just limited to those of limited incomes. As a tenant of 360 East $72^{\text {nd }}$ Street, a rent stabilized building, wrote to Mayor Lindsay: "IT IS IMMORAL for the landlords of the city to drive the middle class out of New York and leave it a haven for the very rich and a jungle for the very poor." ${ }^{39}$ Rather than solving "the urban crisis by keeping middle-income families in the city," another wrote in the Times, "conversions have exactly the opposite effect now." industry that conversions were key to keeping a healthy middle-class population in New York.

Opposition also was not confined to rent regulated buildings. At the Vermeer, a market rate rental building at 77 Seventh Avenue, on the outer edge of Greenwich Village, tenants formed the Vermeer Tenants Organization (VeTO) to oppose a cooperative plan in early 1972. The group was "firmly and completely opposed to the conversion of this building on any terms." 41 Tenants believed that the possibility of increased maintenance costs, a declining real estate market, and "the physical condition of this building makes the purchase of an apartment herein financially unattractive." 42 After all, they had a good deal. Rents in Manhattan were "considerably higher than we are paying here." 43 "We will not move. We will not buy our apartments," the group proclaimed. "We will stay and fight this plan, and we will win."44

Conversion proposals nonetheless tended to provoke the fiercest opposition in buildings protected by rent controls, as was Park Terrace. Why, as one tenant asked, should residents pay a premium for their unit when "they have the alternative of continuing under a landlord with rents subject to control or stabilization?" 45 Conversions were often seen as nothing more than "a beautiful way for landlords to get out from under rent control," as one tenant at 205 West $89^{\text {th }}$ Street mocked, denouncing the plan for her rent controlled building as "absolutely ridiculous."46

Solidarity among tenants, however, was not easy to build or sustain. New York's large apartment buildings frequently contained tenants in different social and economic circumstances. This was particularly the case in rent-controlled buildings, where tenants might range from lower income residents holding on to their apartment out of necessity to the affluent keeping tenancy because of its "cheap" rent. Tenants at 303 East $57^{\text {th }}$ St. for example, asserted that they were united against the offering plan they received early in 1970. Tenant leader Joseph Eckhaus denounced the plan as "avaricious." Just a few months later, however, Eckhaus agreed to purchase his apartment, lured by a substantial price drop. "There were very few comparable apartments around" for the price, he explained in his defense. ${ }^{47}$

The lack of tenant unity in buildings such as 303 East $57^{\text {th }}$ signaled to landlords and others in the real estate industry that, in spite of growing opposition, hope for converting buildings and increasing homeownership in the city was not lost. The real estate industry began to look to new strategies to promote ownership and, in no small measure, to bolster their profits. 


\section{Real Estate Responds}

Stymied by growing tenant opposition, real estate executives and industry organizations turned to the media to make their case about the importance of conversions and homeownership. Conversion advocates recognized the importance of legislative changes that would facilitate conversions, but the widespread tenant outrage that helped lead to an almost immediate reversal of the reduction to 15 percent for rent stabilized buildings signaled to many in the real estate industry that they needed to convince tenants of the benefits of apartment ownership.

To some, this meant better advertisements to induce buyers. Leona Robert (later, Helmsley), then vice president of Brown Harris Stevens, reported with envy to her colleagues of an advertisement for an owner-occupied building in the Los Angeles Times that included a photo of an atomic bomb with text noting "even if they drop a bomb on it (your land or building) you still own the hole. And when the dust settles, the property will still go up in value." 48

Other real estate boosters wrote or were quoted in articles evangelizing homeownership's benefits. Henry Hart Rice of the real estate devolvement and consultant firm James Felt \& Co. asserted in the Times that with a conversion "the tenant knows exactly where his money goes and what it will cost to increase services." 49 Other advocates proclaimed that purchasing one's home was not only a good investment, but that the building would be better maintained and monthly expenses would lessen since former renters would no longer be paying for their landlord's profit.

Conversion boosters also prophesized about how homeownership would benefit communities and the city as a whole. "An apartment owner, like a home owner," Arnold Witte of the Commerce and Industry Association described, "cares for his property, develops an interest in his building, his community, his city, the future of that city and the stability and values of that city." ${ }^{, 50}$ Apartment owners, Robert believed, "want the best schools.... adequate policing of the areas, cleaner surroundings, etc." ${ }^{51}$ To conversion advocates, the link between homeownership and maintaining a vibrant middle class could not have been clearer. "The only way New York will retain its middle class," another proponent proclaimed, "is to permit them to own a piece of it. People have given up on the city, but you don't give up when you have money in it."52

Beyond these arguments, the real estate industry looked for other ways to facilitate homeownership, including legislative changes it believed would be less controversial than the 15 percent reduction. No matter how convincing the claims about homeownership, most tenants found it unfeasible without financing. None of the fiscal and social advantages promised by ownership would lure a tenant into purchasing if s/he lacked the capital necessary to do so. Suburbanites benefited from federally backed bank loans that put financing of their homes within reach of middle and moderate income white male suburbanites. In contrast, cooperative shares were generally not seen as adequate collateral by banks. ${ }^{53}$ As a result, "it's always been easier for an \$8,000-a-year deli man to finance a home in Levittown [Long Island]," as one broker explained, "than it's been for an executive to buy a home - a coop, that is - on Park Avenue." "54

After meeting with "some big movers in the city real estate community," as one paper reported, Governor Nelson Rockefeller proposed legislative changes in 1971 to make financing more readily available. ${ }^{55}$ His urging, along with the support of Assistant Attorney General David Clurman, facilitated the state Assembly's passage of the law that allowed financial institutions to make loans at 1.5 percent above the rate the state allowed for conventional mortgages. ${ }^{56}$ The availability of financing began to put purchasing an apartment within greater reach of the middle class. Observers recognized the magnitude of the change. "Many in the [real estate] industry," as one reporter described, "see the law as nothing less than the savior of the city as a place where middle-class families can live." 57 
But this landmark change would mean little if opposition to conversions remained widespread. Indeed, just as the real estate industry pressured politicians to make laws that would ease conversions, tenants increasingly began to demand that the percentage of tenants needed to agree to purchase their apartments for a conversion to be successful be raised from 35 to 51 percent. Increasing the percentage, a tenant on $\mathrm{E} 79^{\text {th }}$ Street wrote to the City Council, would "remove the tyranny of a minority over the majority." baffled landlords who believed that it was the owner's right to do what they wished with their property. Nonetheless, support for the demand in the heavily tenanted city spread, gaining the endorsement of the Attorney General's office and the editorial board of the New York Times.

These proposals reached a standstill in the early 1970s with legislators unable to agree upon the best course of action for a tenant-dominant city with a powerful and, increasingly troubled, real estate sector. As real estate representatives made their case to officials against a 51 percent requirement, they not only reminded them of the supposed benefits that ownership would bring, but also of the dangers of legislation that would further stymie the industry. New Yorkers were not only suffering under an economy that had declined significantly since in the late 1960s (the city lost 257,000 jobs between 1969 and 1973), but also a severe housing crisis. ${ }^{59}$ Ongoing landlord abandonment in low-income areas was resulting in "sections of the City" becoming "ghost towns," in the words of a 1972 report. ${ }^{60}$ New construction had fallen to less than 2,000 units per year and the costs associated with housing were rising due to inflation, fuel, labor, and debt service costs. New York was suffering a yearly net loss of housing units. ${ }^{61}$

With this clear retreat of investment capital from housing, real estate owners asked, how could legislators risk deepening this crisis by preventing the benefits brought by cooperative conversions? Successful conversions very often led to building improvements as tenants pressured landlords to fund repairs as a condition of approving the conversion. Additionally, despite the ongoing abandonment of tens of thousands of units of rental housing, there was not, conversion advocates pointed out, a single failed cooperative in the city. ${ }^{62}$

Disagreements over altering the laws governing conversions continued, but for the time being the 35 percent threshold stood. It would take a conversion battle unprecedented in size and stature involving one of the most powerful real estate men in the country and a fiercely organized group of tenants in the Bronx to shift the direction of conversions for the entire city.

\section{Parkchester}

Located in the Bronx, Parkchester was the largest rental apartment complex in the nation, with its 12,270 rent controlled units. Parkchester's owner, Harry Helmsley, best known as the owner of splashy Manhattan properties including the Empire State Building, typified the proconversion sentiment among New York's leading real estate figures. Believing both in the necessity of homeownership and that the economic incentives for landlords to maintain their buildings had diminished, Helmsley proclaimed that "the exodus from the city will be stanched" only through conversions. "I would hope," Helmsley continued, "that in 20 years landlords would be a rarity in New York, that everyone would own his own home."63

Helmsley proposed a conversion of the first of Parkchester's four quadrants in 1972, three years after he acquired the property. If Helmsley could successfully convert this vast rentcontrolled complex, many observers believed, a tide of conversions would no doubt sweep over the city, ushering in "a revolution in New York real estate." ${ }^{64}$ As a rent-controlled complex, the law required 35 percent of existing tenants to agree to purchase before a conversion would be 
approved. However, Helmsley used an innovative scheme in which his conversion plan was allowed to proceed based on his agreement not to evict any tenant who wished to remain a renter.

Helmsley's tenants by and large wanted no part in owning their apartments and fought the conversion with an unprecedented fervor. Residents formed the Parkchester Defense Fund, which strategized with other tenant coalitions, protested outside of Helmsley's home, conducted their own surveys of apartments and buildings, and filed suit against Helmsley. ${ }^{65}$ Tenants believed that Helmsley was selling them an "inferior product": a thirty-two year old building with faulty elevators, lax security, and no wiring for air conditioning. Lifetime resident and tenant leader John Dearie asserted the conversion would give tenants "all the headaches of homeownership without any of the advantages. ${ }^{66}$ That Helmsley pledged not to evict any tenants was of little comfort. "If Helmsley succeeds with this and I have to call him to fix a broken pipe," one tenant believed, "I'll be at the mercy of a man who knows the sooner he can get me the hell out, the sooner he can sell my apartment." ${ }^{, 67}$ If the Helmsley plan alone greatly troubled tenants, his proposed profit infuriated them. Though Helmsley had bought the entire complex in 1968 for $\$ 90$ million, converting just 32 percent would net him over $\$ 120$ million. ${ }^{68}$ The profit Helmsley was poised to make from converting the entire complex was a sure sign to tenants that they would be overpaying. It also made clear that a very rich man would become even richer through a conversion that would "destroy" what Parkchester tenants believed to be the "only viable middle-income community in the Bronx." 69

Helsmley likely underestimated how great a foe he had in John Dearie. "Tall, articulate, and movie-star handsome," Dearie capitalized on his overwhelming support in Parkchester by running for and winning a seat in the State Assembly in 1973, making conversions and tenant protections his major campaign issue. ${ }^{70} \mathrm{He}$ wasted little time once elected. He worked quickly to forge contacts and support and also used his position to broadcast tenants' opposition in the press. "Harry B. Helmsley - and his companions - are diligently at work calculating to knock over one established neighborhood after another while reaping incredible financial profit," Dearie began one article. He pointed to the list of developments facing or reported to be soon threatened by a conversion, which was a "who's who" of the major middle-class, rent-regulated complexes in the city: The recent Helmsley purchases of Parkchester in the Bronx, Tudor City (2,800 apartments on Manhattan's eastside) and Fresh Meadows (3,285 apartment in Queens); the 1,830 apartment Windsor Park in Queens; and Peter Cooper and Stuyvesant Town in Manhattan, which together totaled nearly 20,000 apartments. Dearie ended with a warning from city tenants: "Look out, Harry Helmsley and Company, we're coming on strong!"71

Dearie worked to elevate city tenants' collective political power in the struggle against conversions. While TACC sought to bring together tenants from individual buildings that were primarily in Manhattan and often had no prior collective associations, Dearie augmented this strategy by organizing alongside tenant leaders from the major rental complexes threatened by conversions. These spread across several boroughs, often had well-organized tenant associations, and collectively offered the potential of mobilizing well over a hundred thousand residents.

Working with "a new breed of tenant leaders who have rallied their respective tenant associations around legislative reforms," Dearie developed an extensive legislative proposal to give tenants more leverage in a proposed conversion. ${ }^{72}$ With such extensive tenant support behind him, Dearie found a co-sponsor in powerful state senator Roy Goodman, who, as a member of the state senate's Republican majority, helped push the law through the legislature. Among several other provisions that advantaged tenants, the bill required landlords to gain at least 35 percent of existing tenants' approval within one year for all plans. Previously, landlords 
could proceed with conversion plans if they agreed not to evict any tenants in residence. Dearie's law would create tremendous impediments to successful conversions. ${ }^{73}$

The real estate industry vehemently opposed the bill. "Why should the economic future of an owner's investment be controlled by people who do not have an equity position in the project?" one landlord asked. ${ }^{74}$ Building owners claimed that by giving tenants too great of a hand in the negotiating process, the bill removed any economic inventive to convert a building.

Impassioned tenants countered. Several of the tenant associations of major complexes joined with a recently formed lobbying group, the New York Tenants Legislative Coalition. ${ }^{75}$ Tenant leaders at the Helmsley-owned complexes mobilized busloads of residents to attend rallies, legislative hearings, and lobbying sessions at City Hall and in Albany. Tenants also flooded legislators with fervent letters supporting the legislation. John Whalen, the President of the Parkchester Defense Fund, wrote to Governor Malcolm Wilson that without his approval of the bill, "you will give carte blanche to all the Helmsley's lurking in the shadows.... [to] make scandalous profits at the expense of those least able to pay." He continued, "To Helmsley, Parkchester is 12,500 [sic] apartments but to us it is a community of 12,500 families..... It is home - for some the only one we have known - for many, the only one we can afford.",76

The bill passed, enacting Dearie's law for two years, with extensions requiring further legislative action. The law blocked the conversion plans for Parkchester and caused Helmsley to delay his conversion plans for his other recently purchased complexes. " "Tenant power!" Helsmley jeered. "If they want tenant power, let them own the building.",78

\section{Real Estate during the Fiscal Crisis}

Conversions throughout the city plunged after the passage of the Dearie-Goodman law in 1974. There were only thirty-six plans submitted in 1974 and seventeen in 1975; most were tenant-initiated conversions in small buildings that tenants feared owners might abandon. ${ }^{79}$

The law's passage also coincided with the beginning of the city's fiscal crisis, which lessened the appeal of co-op apartments as investments. The city's worsening economic state reached its nadir in the mid-1970s during which New York teetered on the brink of bankruptcy. The business, finance, and banking leaders who took control over the city's economy during the height of the crisis implemented a severe austerity program, including layoffs to the municipal workforce, an end to free tuition throughout the city's college system, and increased subway and bus fares alongside reduced services. They stripped funding from parks, public schools and the municipal hospital system. Though such policies were most punishing to the poor and lower classes, reduced public services likely did little to encourage many among the middle class that the city was worthy of a personal and financial investment as substantial as purchasing a home.

Yet, all was not bleak for the real estate industry during the fiscal crisis. Two major developments signaled not just the possibilities for successful development but also how homeownership could be at the center of revitalization efforts. The first was the emergence of luxury condominiums. Unlike a cooperative, buyers of a condominium owned their apartment outright and could sell it without the approval of a building's board. Though a "condominium craze" was sweeping the nation in the mid-1970s - with condominiums accounting for 25 percent of all new housing nationwide in 1973 and 1974 - the cooperative's longstanding history in New York helped ensure that they continued to be overwhelmingly favored in the city. ${ }^{80}$

But some shrewd developers sensed a potential market for luxury condominiums, particularly among wealthy foreign purchasers who had long looked to maintain a non-primary home in New York (condominiums were much more popular outside of the U.S.). Few observers 
would have likely anticipated that buildings with unprecedented prices and luxury amenities during the height of the fiscal crisis would be successful. But they were. Indeed, just as the fiscal crisis, and the atmosphere around cooperative conversions, reached its nadir, the market for luxury condominiums soared. These projects became powerful illustrations of how even in the midst of crisis New York retained elements of its longstanding desirability, at least for the ultra wealthy. At The Galleria on East 57th St., for example, apartments cost up to \$1.2 million and the building included a 34,000 square foot club with a year-round swimming pool, cocktail lounge, athletic facilities, and a "sky terrace" with indoor and outdoor butler-attended areas. ${ }^{81}$ Over 50,000 prospective purchasers viewed model apartments when the Galleria opened in 1975, with the waiting list for the more popular units growing over 300 names long. That most purchasers were corporations or super rich foreigners buying their second or third homes did little to dampen the enthusiasm of developers. "Even businesses moving out of the city aren't moving very far," as one building representative explained in 1976, "They come back here to entertain." ${ }^{, 2}$ Many foreign purchasers believed that, despite the city's troubles, New York made for a safer investment compared to political and financial instabilities at home. ${ }^{83}$

Condominiums were not the only bright spot for the real estate industry during the fiscal crisis. Though artists had been living in a small Manhattan neighborhood south of Houston St. for decades, it was not until 1960s that the area - by then called SoHo - began to emerge as a hub of artistic activity. ${ }^{84}$ Artists moved into large lofts that were opening as the area's light industry declined. By the mid-1970s, SoHo had become home to an increasing number of middle-class residents who were less likely to make their living through art. $^{85}$ A 1977 study of converted Manhattan loft buildings found that 33 percent of residents had moved to their apartment from outside the city and that they had household incomes twice the city's median. ${ }^{86}$

While most lofts remained as rentals, many were converted to cooperatives. These spaces, many real estate experts and officials believed, were the "most important." ${ }^{87}$ So vital were these cooperatives to the area's revival that in 1975 Attorney General Lefkowitz took the unprecedented action of "legalizing" the thousands of cooperative apartments that had been formed, even though few had been sold in accordance with state law. ${ }^{88}$ As one housing expert explained, "the occupants of coop lofts emerge as the most committed to living and working in New York City. They are drawn to loft living by the ample space, the chance to customize it, and the opportunity for home ownership." 89

Real estate officials were quick to point to the significance of these successful homeownership initiatives in the midst of the economic crisis. As Brewster Ives, the longstanding chairman of the leading firm Douglas Elliman-Gibbons Ives wrote in his company's newsletter: the "substantial number" of condominium and cooperative purchasers coming from Western European and Southern America as well as "many parts of the country, including the outlying suburbs" signified New York's reemergence as the world's "financial center[,]... cultural center,.... [and] most exciting city." These developments, Ives continued, gave "hope for more cooperative and condominium conversions to replenish the dwindling supply of desirable apartments and to reverse the deterioration" of the housing stock. There was, Ives wrote to his colleagues, "hope for the future of the City of New York.",90

The success of luxury condominiums and loft cooperatives fueled support for allowing the Dearie-Goodman law to expire. The real estate industry, unrelenting in its opposition to the law, compounded the political pressure to do so. Reminding Governor Hugh Carey that the "declining real property tax base is at the root of our financial crisis," REBNY President D. Kenneth Patton wrote that the barriers imposed on conversions in the state "ranks with the most 
pernicious elements of our public policies." "C1 "Cooperatives and condominiums are the way of the future and the salvation of this city because it means that these properties will be preserved and well maintained," Brewster Ives told state officials. Co-op and condo ownership, "which has become such a large source of strength in our better residential areas, should be allowed to grow unhampered by legislative restraints - all for the greater good of our City and our State."${ }^{.92}$

After a one year extension in 1976, the law was allowed to expire in $1977 .{ }^{93}$ Many politicians came to trust that rent stabilization and control laws protected tenants sufficiently, a position also voiced by media commentators and real estate experts. ${ }^{94}$ Many politicians also believed that the law effectively ending conversions was too extreme a step, particularly as conversions offered "hope that decent but deteriorating rental apartment houses might be saved by converting them into cooperatives," as the New York Times noted in one of several editorials against the law's extension. ${ }^{95}$

Though opposition to conversions remained prominent into the next decade, the law's expiration coincided with several major occurrences that to begin to shift such sentiments, especially for a growing number of middle-class residents, in more positive directions.

\section{The Growth of Conversions in New York}

At the end of the 1970s, a small number of fledgling post-conversion owners began to champion their place in and contribution as new middle-class apartment-owners, countering strong renter opposition to conversions. This was most powerfully evident in the formation of organizations and publications by and for fledgling cooperative owners. While in the early 1970s, tenants faced conversions with befuddlement and horror, these new groups and publications helped to inform, assure, and normalize cooperative living in the city, ushering in a vastly changing attitude toward cooperative and condominium ownership.

The most prominent of these groups, the Council of West Side Cooperatives (CWSC), first formed in 1974 by a small number of new cooperative owners to educate themselves and others about running their buildings. ${ }^{96}$ But the group soon began to take on a more public role by asserting itself as the face of the city's new middle-class cooperatives. The group, for example, corrected negative sentiments about cooperative ownership in the press. When an article in Our Town, a popular Manhattan weekly paper, left readers with the "discouraging" impression that cooperative shareholders suffered under high maintenance changes, Marc Luxenberg, president of the CWSC, replied with the findings from its member survey, which proved them to be much lower. He also disputed the claim that families escaping the suburbs would not want to live in a co-op. "The principal burdens of house ownership usually involved physical maintenance of the structure and the surrounding acreage," Luxenberg noted, "and such unpleasant tasks as mowing the lawn, raking the leaves and shoveling the snow. A co-op does not have those problems."

The group also spoke out in hearings and in the media against the extension of the Dearie-Goodman law. While tenant groups and Attorney General Lefkowitz called for retaining if not strengthening the law, the CWSC spoke alongside landlord and builder representatives. "In this time of fiscal crisis," the group proclaimed, "no policy can be more destructive than one which discourages private investment in the city." 98

By 1980, the group's widening focus resulted in a name change to the Council of New York Cooperatives, which represented over 900 coops with over a quarter million residents and aimed "to act as a clearing house for co-op information, to provide for the common needs and interests of co-op apartments.... to establish cooperatives as a united community with interests that are separate and distinct from rental apartments; and to participate in political action 
favorable to this co-op community." "99 Its first annual conference featured over twenty-five workshops and attracted close to 400 representatives from existing and converting cooperatives.

Such efforts to inform and organize the fledgling cooperative community were extended through new publications. The Manhattan Cooperator launched as the first citywide coop newspaper in April 1981 and New York Habitat - "a magazine for co-op, condominium, and loft living" - followed in May 1982. As Vicki Chesler and Matt Kovner, the publishers of the Manhattan Cooperator wrote in the editorial of its initial issue, the publication sought to "create an integrated and well-informed co-op community" where none existed. "By moving into a coop, or helping to convert your building to one," the editorial noted, "you have shown that you believe in the future of New York City; that you feel it to be a vital, thriving place in which to live and work - a place worthy of investment, and worthy to be called home."100

New York's mayor, Edward I. Koch, who took office in 1978 lauded these new middleclass cooperative owners. As Koch's Commissioner of Housing Preservation and Development Anthony Gliedman told attendees of CNYC's first conference, "both the Mayor and I want to see this effort continue and expand." ${ }^{, 101}$ Indeed, Koch represented a new generation of big-city mayors in the late 1970s who believed that cities should invest in attracting wealthy residents. Several studies at the time demonstrated that those purchasing apartments in conversions in the wake of the expiration of Dearie-Goodman were exactly the types of residents the administration hoped would commit to making the city their home: dual-earner professional households. ${ }^{102}$

Koch's certainty that the city needed moneyed residents to regain its economic footing was reflected both in his appeals to these residents as well as in his pushing for housing policies that he believed would help attract them. Koch used his inauguration address in 1978 not just to promise "better services for the middle-class," but to make an appeal to "urban pioneers" - as the Times described them - to "come east and join us" in revitalizing New York. ${ }^{103}$ In the suburban areas as well as many of the cities from which Koch hoped to attract these residents, home owning - not renting - was the norm. Koch was thus a strong advocate of measures that might increase homeownership opportunities so as to facilitate the shift in the composition of city residents. He championed conversions, believing that "a tenant's ownership of his or her apartment fosters commitment and stability to our neighborhoods." ${ }^{104}$ Koch not only encouraged fledgling cooperative organizations, but also publically defended conversions from criticisms and ensured that none of the legislative proposals to raise the number of tenants in eviction plans to 51 percent were successful during his first few years in office. ${ }^{105}$

The penetrating new voice of successful middle-class cooperative owners, along with a unabashedly supportive mayor in office, made it easier for the real estate industry to point to what they had long claimed: co-oping was good for the middle class and the city. Landlords capitalized by approaching conversions with new methods to ensure that proposed conversions were less contentious and more successful. The most important was insider pricing. Because the overall potential for profit in a conversion was so great, in larger buildings, landlords could sell apartments to tenants at as low as one-third their market rate and still profit significantly. Insider pricing made apartments affordable to a far greater range of tenants than in the past. But just as importantly, with New York's real estate market rapidly heating up in the late 1970s, it created tremendous potential for windfall profits. It was not uncommon for a tenant to purchase an apartment at an insider price and initiate a sale the next day at well over double the price. Perhaps no factor around this time facilitated landlords being able to reach the requisite number of tenant purchasers to turn a building into a cooperative than tales of the windfall profits neighbors, co-workers, and friends were beginning to make through conversions. 
Legislative battles continued in the early 1980s between representatives who wanted conversions to proliferate and those who sought greater protections for tenants. In 1982, the two parties finally came to an agreement. Senate Republicans from New York City who had long opposed legislation that might hinder conversions had come under pressure from tenants in their districts. They finally agreed to raise the number of bona fide tenants needed to agree to purchase their apartments in order for an eviction plan to be approved to 51 percent. But these Republicans also forced pro-tenant politicians to change a requirement in non-eviction plans to make them easier to achieve by enabling apartments sold to non-residents to count towards achieving the 15 percent of sales needed for a non-eviction plan to be approved. ${ }^{106}$ Tenant leaders therefore won a longstanding goal of making eviction plans exceedingly difficult to accomplish - thereby greatly discouraging their use - but in so doing allowed for the "noneviction loophole," in the words of a critical tenant advocate. ${ }^{107}$ The change all but assured most plans going ahead would be non-eviction plans and that these plans would be easier to achieve.

Shifts in the city's rent regulations reinforced these developments. Legislation at the end of the 1960s and early 1970s diminished the number of rent-controlled units from over one million in 1970 to less than 285,733 by $1981 .^{108}$ Though many of these apartments remained protected by the far less powerful rent stabilization, the change meant much greater rent increases for hundreds of thousands of tenants. Thus, the benefits associated with ownership appeared only to grow, making it increasingly likely that even in buildings with rent protections, tenants looked at ownership more favorably. Additionally, conversions compounded other policies that directly diminished rent regulations. Even if a rent controlled or stabilized tenant refused to purchase her apartment and was not evicted during her building's conversion, once that tenant vacated the apartment, it was de-regulated and could be sold or re-rented at market rates. With non-eviction conversion plans relatively easy to achieve after 1982 by selling only 15 percent of units, landlords were further encouraged to initiate conversions as a deregulation mechanism. In some buildings, few tenants beyond the initial 15 percent of purchasers came to own their apartments after a conversion of a rent regulated building, as vacated apartments of non-purchasers were simply re-rented at market rates. ${ }^{109}$

The combination of these factors helped shift the tide of conversions - and of homeownership more generally - in New York. Legal changes ameliorated what were to many tenants the most objectionable aspects of conversions, the real estate industry softened its approach through insider pricing and non-eviction plans, and ambitious early converters arose within a city of increasingly less protected renters to proclaim that conversions had benefited them, to encourage their proliferation, and to normalize the place of middle-class owners.

\section{Conclusion}

Though some opposition to conversions remained, by the early 1980s, the sentiment towards homeownership and its place in New York City had changed. There was perhaps no greater indication of this than at Parkchester. At the complex where tenant opposition had shut down conversions not just at the development but across the city and state, Harry Helmsley filed a non-eviction conversion plan for the remaining three quadrants in 1983 and their tens of thousands of residents. In sharp contrast to eleven years before, the tenants' committee took a new position: neutrality. John Dearie, who remained president of the tenants' association, said, "Now we are neither for nor against. Our responsibility is to convey the facts on the tenants' rights." 110 Though apartments were still overwhelmingly protected by rent control or stabilization, tenants no doubt observed that outsider prices were 110 percent higher than they 
were when sales started years earlier. As such, the tenants' association now saw its responsibility as helping tenants who want to buy to "strike a better deal."

Conversions grew substantially in the late 1970s and early 1980s. The number of building plans submitted to the Attorney General rose from 117 in 1976 to 403 in 1980 and then to 1,029 in 1982. ${ }^{111}$ Cooperative housing units in New York went from 138,000 to 233,377 between 1975 and 1982, with over 11,000 new condominium units. ${ }^{112}$ Conversions also continued to spread in greater numbers in the outer boroughs, particularly in Queens and in Brooklyn where, the Times wrote, cooperatives were "leading [the] latest renaissance. ${ }^{13}$ By the end of the decade, the percentage of homeowners had grown to 28.4 percent, the highest in the city's history. ${ }^{114}$

The conversion of rental housing helped usher in a remarkable turnaround in real estate. "The push to co-op," in the words of one observer in 1980, "has outstripped the garment industry as the city's number one industry." 115 This was especially true in Manhattan. The average price of Manhattan cooperatives sold by Douglas Elliman, for example, went from $\$ 57,800$ in 1975 to $\$ 626,977$ in 1985 , an astonishing nearly eleven-time increase. ${ }^{16}$ The growth of cooperative conversions and the continued development of new condominiums were central to the contributing factors of these escalating prices: swelling demand from moneyed newcomers and current residents (who now had greater ability to own their apartments), meager construction of new housing other than condominiums, and a diminishing stock of rent regulated housing. ${ }^{117}$

Not everyone applauded the changes the explosive growth of conversions and condominiums were causing. Queens Congressman Benjamin Rosenthal, who had for years opposed conversions, said in 1981, "I am concerned that the middle class is being pushed out of the city and that Manhattan may become an enclave for the wealthy." "118 But it was not just longstanding critics like Rosenthal who saw New York changing for the worse. Conversions had no greater advocate than Brewster Ives of Douglas Elliman, who was widely recognized as the "elder statesman" of the cooperative and condominium movement. But he too had come to express alarm at the effects the growth of cooperatives and condominiums were having. "I hate to say it," he noted in 1981, "but I don't see how we are going to hold the middle class in Manhattan. The New York of the future will in large part be for the wealthy - be they Americans or foreigners - and for the subsidized poor." 119

In the 1970s, New Yorkers contested claims about the importance of ownership in the city. Few tenants embraced the chance to own their homes and instead struggled aggressively against the notion that ownership would secure a continued place for the middle class. Tenants organized to protect their homes and those of their neighbors by challenging pro-conversion real estate boosters and, commonly, by pointing to the security of state-regulated rental housing.

The ultimate growth of conversions and real estate prices in the 1980s gives temptation to attribute this development solely to a powerful real estate industry or to the unabashedly progentrification policies of leaders like Koch. Critical too, however, was the emerging acceptance of conversions and ownership by tenants. Similarly, the growing disparities associated with the economic revitalization in the 1980s did not occur simply as a result of top-down policies by political leaders who embraced urban neoliberalism, but also through grassroots support from those who benefited economically. In the case of cooperative conversions, this included the very types of people who had earlier led campaigns to preserve economic diversity and rent regulated housing. Tenant reception to conversions grew especially as larger numbers came to believe that they themselves could benefit economically from conversions and accessing accelerating real estate values. As the momentum against conversions dissipated in the 1980s and was replaced by a movement of cooperative converters, tenants still organized in great numbers in response to the 
proposed conversions of their building. They just increasingly did so not to block the conversion but to win as lucrative a deal as possible. Refrains common among those who ferociously battled conversions in the 1970s, such as the importance of preserving rent regulations for retaining moderate and middle-income residents in the city, diminished in the 1980s.

Though New York would remain largely a city of renters, homeownership began to grow in prominence in the 1980s in ways that helped restructure the built environment and economic composition of the city. It also helped facilitate what had long been a politically untenable goal of the real estate industry: diminishing rent regulations of much of rental housing. In so doing, homeownership compounded the shift away from an era of state intervention and regulation towards one of free markets and privatization. The changing attitude towards apartment ownership, a mayor willing to privilege real estate development above nearly all else, and the reinvestment of capital by the real estate industry would finally lead to the "revolution in real estate" that observers initially predicted when Helmsley first tried to covert Parkchester in the early 1970s. 


\section{Notes}

${ }^{1}$ Quoted in "Tompkins Warns on Co-Op Curb," The Real Estate Reporter, August 25, 1969, 1.

${ }^{2}$ See, for example: Lizabeth Cohen, A Consumers' Republic: The Politics of Mass Consumption in Postwar America (New York: Alfred A. Knopf, 2003); Kenneth Jackson, Crabgrass Frontier: The Suburbanization of the United States (New York: Oxford University Press, 1985); Robert Self, American Babylon: Race and the Struggle for Postwar Oakland (Princeton: Princeton University Press, 2005); and Craig Steven Wilder, A Covenant with Color: Race and Social Power in Brooklyn (New York: Columbia University Press, 2000).

${ }^{3}$ In 1960, 21 percent of the city's housing inventory was owner-occupied, with much of this stock concentrated in single-family homes in the outer boroughs or in owner-occupied units in small rental buildings. Cooperatives - the principal homeownership structure in the multi-family buildings that dominated much of New York's built environment - accounted for less than 1 percent of the housing stock at that time. Department of Housing and Urban Development, Condominium/Cooperative Study. Volume 2 (July 1975), C-9-11. Following the enactment of zoning regulations in the mid-1960s, new construction plunged. Only one privately built cooperative opened in Manhattan between 1966 and 1967, and none were completed in either 1968 or 1969. Franking Whitehouse, "Co-op Drought Goes on Here for 2d Year," New York Times, May 11, 1969.

${ }^{4}$ Between 1966 and 1968 alone, landlords abandoned an astonishing 100,000 rental apartments, a total greater than the number of units demolished through "urban renewal" over the previous twenty years Alan S. Oser, "Housing Supply in City Eroding Amid Construction Standstill," New York Times, February 8, 1970.

${ }^{5}$ Quoted in Joseph P. Fried, “Rent Rises: Exorbitant or Not,” New York Times, July 28, 1968.

${ }^{6}$ Quoted in Alan S. Oser, "Shift to Coops Grows in City," New York Times, November 23, 1969.

7 “Tompkins Scores Bill On Co-Op Conversions," The Real Estate Reporter, April 12, 1971, 1.

${ }^{8}$ Herman B. Glaser, "Letter to the Editor," New York Times, December 6, 1970.

${ }^{9}$ Kristina Ford, Housing Policy and the Urban Middle Class (New Brunswick: The Center for Urban Policy Research, 1978), 119.

${ }^{10}$ George Goodman, Jr., "Co-Op Curbs Asked By Tenant Groups,” New York Times, March 26, 1972.

${ }^{11}$ Thomas W. Ennis, “More Tenants Seeking ‘Landlord’ Role,” New York Times, March 16, 1969.

${ }^{12}$ Louis Smadbeck, "For Reasonable Attitude on Co-Ops," New York Times, December 12, 1971. 
${ }^{13}$ As in retail, property owners could make far more by selling directly to consumers than by operating as wholesalers.

${ }^{14}$ W. Dennis Keating, "Rent Regulation in New York City," in Rent Control: Regulation and the Rental Housing Market, edited by W. Dennis Keating, Michael B. Teitz, and Andrejs Skaburskis (New Brunswick: Center for Urban Policy Research, 1998), 156.

15 “Seminar on How to Co-op Apts," The Real Estate Reporter, October 6, 1969, 1.

${ }^{16}$ Unattributed 1969 newspaper article entitled "Rent Bill Hearing Will Draw Debate at City Hall.” Included as part of New York City Council Records, Series: Local Laws, Box 50267, Local Law 50, Conversion of Cooperative or Condominium, 1969, The LaGuardia and Wagner Archives, Fiorello H. LaGuardia Community College/CUNY.

${ }^{17}$ Quoted in “Tompkins Warns on Co-Op Curb," The Real Estate Reporter, August 25, 1969, 1.

18 The Rand Corporation study blamed rent control for the staggering number of apartments estimated at 38,000 each year - being abandoned by owners in the city's low-income areas. See Ira S. Lowry, Rental Housing in New York City, Volume 1: Confronting the Crisis (New York: The New York City RAND Institute, 1970). See also: Condominium/Cooperative Study. Volume 2, C-9-11. Another study by Rutgers University's George Sternlieb claimed that by reducing property values, controls discouraged upkeep and maintenance by owners, even though his "data demonstrated no consistent relationship between rent control and either disinvestment or housing deterioration" in the words of two critics. David Bartelt and Ronald Lawson, "Rent Control and Abandonment: A Second Look at the Evidence," Journal of Urban Affairs, Vol. 4, Issue 4 (September 1982), 53. See also: Ronald Lawson with Reuben E. Johnson III, "Tenant Responses to the Urban Housing Crisis, 1970-1984," in The Tenant Movement in New York City, 1904-1984, edited by Ronald Lawson with the assistance of Mark Naison (New Brunswick: Rutgers University Press, 1986), 211.

${ }^{19}$ Abandonment was most likely the result of years of redlining and disinvestment from housing in lower income areas both by financial institutions and individual landlords, which was exacerbated by factors such as landlord 'milking' and speculation, inflation, paltry incomes of low-income tenants, tenants' changing financial circumstances including access to welfare payments, amateur landlord mismanagement, reduced municipal services, and the building's age and condition.

${ }^{20}$ Bartelt and Lawson, "Rent Control and Abandonment," 51. On the links between redlining, reduced municipal services, and urban decline, see, for example: Themis Chronopoulos, "The Lindsay Administration and the Sanitation Crisis of New York City, 1966-1973," Journal of Urban History 40 (November 2014): 1138-54; Joe Flood, The Fires: How a Computer Formula, Big Ideas, and the Best of Intentions Burned Down New York City - and Determined the Future of Cities (New York: Riverhead Books, 2010); Matthew Gandy, "Between Borinquen and the Barrio: Environmental Justice and New York City's Puerto Rican Community, 1969-1972," 
Antipode 34 (September 2002): 730-61; Brian Purnell, Fighting Jim Crow in the County of Kings: The Congress of Racial Equality in Brooklyn (Lexington: University of Kentucky Press, 2013); Walter Thabit, How East New York Became a Ghetto (New York: New York University Press, 2003); Wilder, A Covenant with Color.

${ }^{21}$ For an overview of housing policies related to rent control and stabilization during the Lindsay administration, see Keating, "Rent Regulation in New York City," 155-161.

22 Tony Sanders, “Mayor's Homeownership and Home Improvement Program” July 31, 1969, 2. Mayor John V. Lindsay Collection. Subject Files, Roll 13, Municipal Archives of the City of New York (hereafter, MACNY).

${ }^{23}$ Alan S. Oser, "Shift to Co-ops Grows in City,” New York Times, November 23, 1969.

24 Thomas W. Ennis, “Co-op Conversions Amended by State,” New York Times, June 22, 1969 and Oser, "Shift to Co-ops Grows in City."

${ }^{25}$ Rental buildings had been converted to cooperatives for several decades, but conversions were infrequent and limited to only one area of Manhattan: the Upper East Side, home to much of borough's affluent housing. See Matthew Gordon Lasner, High Life: Condo Living in the Suburban Century (New Haven: Yale University Press, 2012), 258. Though there had been some opposition to conversions earlier in the decade, at the end of the 1960s the growing number of proposed conversions along with a slumping stock market and conversion proposals beginning to spread from affluent to middle class buildings throughout the city buoyed opposition.

${ }^{26}$ Rita A Savoy to Honorable Louis J. Lefkowitz, June 2, 1969, Mayor John V. Lindsay Collection, Deputy Mayor Robert Sweet, General Correspondence, Box 5035, Folder: Rent and Rehabilitation, MACNY.

${ }^{27}$ For an excellent overview, see Lasner, High Life, 263-5.

${ }^{28}$ Attorney General Louis Lefkowitz to Mayor John V. Lindsay, May 12, 1969, Mayor John V. Lindsay Collection, Deputy Mayor Robert Sweet, General Correspondence, Box 5035, Folder: Rent and Rehabilitation, MACNY.

${ }^{29}$ See: Thomas W Ennis, "State Bars Plan to Set Up Co-ops,” New York Times, May 14, 1969 and Thomas W. Ennis, "Co-op Conversions Amended by State."

${ }^{30}$ Author interview with David Clurman, October 25, 2012. See also: Ennis, "Co-Op Conversions Amended by State."

31 "Report on Meeting of New York City Tenants' Association for Fair Cooperative Practice," March 21, 1970, The Metropolitan Council on Housing Records, TAM.173, Box 17, Folder "Coop/Condo Conversion 1970-1974 \#1," Tamiment Library/Robert F. Wagner Labor Archives, New York University. 
32 These included a moratorium on all cooperative conversions until the city's vacancy rate increased, that no conversion be approved unless two-thirds of active tenants approved the plan, and that if the plan were not approved by tenants within ninety days of its offering the landlord be prevented from issuing another plan for three years.

33 "N.Y.C. Tenants Association Against Unfair Cooperative Practices flier," April 15, 1970, The Metropolitan Council on Housing Records, TAM.173, Box 17, Folder "Coop/Condo Conversion 1970-1974 \#1,” Tamiment Library/Robert F. Wagner Labor Archives, New York University.

34 “Stop Cooperative Coercion Now! Flier," Undated but likely early 1970s, The Metropolitan Council on Housing Records, TAM.173, Box 17, Folder "Coop/Condo Conversion 1970-1974 \#1,” Tamiment Library/Robert F. Wagner Labor Archives, New York University.

35 Judith C. Lack, “Apartments Go Co-op 'Outside the Law',” New York Times, January 5, 1975.

36 “Park Terrace Gardens Tenants' Association Opinion of the Prospectus for the Co-Operative Plan, 1971," 8, The Metropolitan Council on Housing Records, TAM.173, Box 17, Folder “Coop/Condo Conversion 1970-1974 \#1," Tamiment Library/Robert F. Wagner Labor Archives, New York University.

${ }^{37}$ Rita A Savoy to Honorable Louis J. Lefkowitz, June 2, 1969.

${ }^{38}$ Housing and Urban Development, Division of Policy Studies, The Conversion of Rental Housing to Condominiums and Cooperatives. Volume 2 (June 1980), 217

${ }^{39}$ Unknown author, letter to Mayor John V. Lindsay, December 17, 1969, The Metropolitan Council on Housing Records, TAM.173, Box 17, Folder "Coop/Condo Conversion 1970-1974 \#1,” Tamiment Library/Robert F. Wagner Labor Archives, New York University.

${ }^{40}$ Christine E. Samurovich, "Pro,” New York Times, April 22, 1973.

${ }^{41}$ Vermeer Tenants Organization Bulletin, February 3, 1972, The Metropolitan Council on Housing Records, TAM.173, Box 17, Folder "Coop/Condo Conversion 1970-1974 \#1," Tamiment Library/Robert F. Wagner Labor Archives, New York University.

${ }^{42}$ Vermeer Tenants Organization Flier, January 1972, The Metropolitan Council on Housing Records, TAM.173, Box 17, Folder “Coop/Condo Conversion 1970-1974 \#1," Tamiment Library/Robert F. Wagner Labor Archives, New York University.

${ }^{43}$ Vermeer Tenants Organization Bulletin, February 24, 1972, The Metropolitan Council on Housing Records, TAM.173, Box 17, Folder "Coop/Condo Conversion 1970-1974 \#1," Tamiment Library/Robert F. Wagner Labor Archives, New York University.

${ }^{44}$ Ibid. 
${ }^{45}$ Henry Miller, “Letter to the Editor,” New York Times, January 9, 1972.

${ }^{46}$ Oser, "Shift to Co-ops Grows in City."

${ }^{47}$ David A. Andelman, "In the Excelsior, Bitterness Replaces Tenant Unity," New York Times, August 2, 1970.

${ }^{48}$ Leona Mindy Robert, "Cooperative Apartments - A Important Factor in Housing," Real Estate News, April 1971, 11.

${ }^{49}$ Henry Hart Rice, “Co-ops in New Form Can Save Housing," New York Times, January 24, 1971.

${ }^{50}$ Arnold Witte, Commerce and Industry Association of New York, Inc., "Concerning Cooperative Apartment Restrictive Legislation, Prepared for Presentation before the City Council Committee on Housing, March 22, 1971," New York City Council Records, Series: Committee Files / Proceedings I, Box 50803, Housing Committee, Introduction 113, Converting to Cooperative Ownership, 1970, The LaGuardia and Wagner Archives, Fiorello H. LaGuardia Community College/CUNY.

${ }^{51}$ Robert, “Cooperative Apartments,” 11.

${ }^{52}$ Quoted in Mandelbaum, "Tenants Evaluate Shift to Co-Op."

${ }^{53}$ After all, if an owner faced foreclosure and the bank took over the apartment, there was nothing to stop the cooperative board from rejecting potential new owners, all while keeping the banks on the line for maintenance fees. See, for example: "Banking Superintendent Sees Cooperative Apartment Loan Program Expanding Rapidly Soon," Real Estate News, February 1972, 30 and Lasner, High Life, 265-66. With privately developed cooperatives in New York traditionally the domain of the very affluent, financing had typically not been needed. When offered, it was commonly through personal loans. These policies hardly benefited middle class purchasers, as without a home they typically had little to provide as collateral.

${ }^{54}$ Quoted in Peter Hellman, “The New Way to Buy a Co-Op,” New York, January 24, 1972, 52.

${ }^{55}$ Hellman, "The New Way to Buy a Co-Op," 54.

${ }^{56}$ See: Lasner, High Life, 265; Alan S. Oser, "Broad Loan Aid to Buy Co-Ops Found Unlikely," New York Times August 1, 1971; and Condominium/Cooperative Study, C-21.

${ }^{57}$ Hellman, "The New Way to Buy a Co-Op," 52.

${ }^{58}$ Samuel Boksenbom to Hon. Donald R. Manes, Chairman. New York City Council Records, Committee Files / Proceedings I, Box: 50804, Housing Committee, Introduction 113, Converting 
to Cooperative Ownership, 1970, The LaGuardia and Wagner Archives, Fiorello H. LaGuardia Community College/CUNY.

${ }^{59}$ Vincent Cannato, The Ungovernable City: John Lindsay and His Struggle to Save New York (New York: Basic Books, 2001), 549.

${ }^{60}$ Robert Kolodny, Study of Low-Income Cooperative Housing Conversion in New York City: Interim Report (August 1972). Sponsored and Published by United Neighborhood Houses, prepared under contract with The Borough Improvement Board of Manhattan.

${ }^{61}$ Condominium/Cooperative Study. Volume 2, C-3.

${ }^{62}$ See, for example, "The Case for Conversion to Co-ops: Sulzberger Testifies," Realty, May 3, 1977.

${ }^{63}$ William G. Connolly, "Helmsley Makes Parkchester a Testing Ground," New York Times, December 24, 1972 and William G. Connolly, "Parkchester Condominium Authorized," New York Times, December 15, 1972.

${ }^{64}$ Connolly, "Helmsley Makes Parkchester a Testing Ground."

65 "Parkchester Tenants Act to Bar Condominium Conversion Plan," New York Times, April 4, 1974. Quote from John J. Whalen, President of the Parkchester Defense Fund to Governor Malcolm Wilson, June 3, 1974, Bill Jacket, L. 1974, ch. 1021, New York State Archives.

${ }^{66}$ Parkchester Tenants Association Condominium Information Sheet,” January 4, 1973, Ronald Lawson: Tenant Movement in New York City Research Files, TAM.214, Box 14, Folder "Parkchester Tenants Association Folder" (second folder of several with this name), Tamiment Library/Robert F. Wagner Labor Archives, New York University.

${ }^{67}$ Allan M. Siegal, "In Parkchester, Old Tenants Fear Condominium Plan,” New York Times, June 6, 1974.

${ }^{68}$ Report on Housing and Rents of the Temporary State Commission on Living Costs and the Economy of the State of New York to the Governor and the Legislature (January 1974). Papers of Governor Hugh Wilson, Reel 27, Subject: Housing General (Misc.), 1974 January - February, Section VI: Cooperative and Condominium Conversions, 2, The New York State Archives.

69 "Parkchester Tenants Meeting" April 9, 1974, Ronald Lawson: Tenant Movement in New York City Research Files, TAM.214, Box 14, Folder "Parkchester Tenants Association Folder," Tamiment Library/Robert F. Wagner Labor Archives, New York University.

${ }^{70}$ Georgia Bullea, “It's Decision Time at Parkchester," New York Times, February 4, 1973. 
${ }^{71}$ John Dearie, "The Conversion Game: The Newest Housing Crisis," Village Voice, April 11, 1974, 14, 18.

72 Ibid., 18.

${ }^{73}$ If owners proceeded with an eviction plan, they previously were able to hold a percentage of apartments vacant before the conversion and then could count sales of these units in reaching 35 percent. Under the new law, landlords who proceeded with eviction plans for rent controlled buildings could not count sales to outsiders in reaching 35 percent and had only six months to achieve the requisite number of sales. However, if the building was predominately rent stabilized, landlords could count sales to outsiders in reaching 35 percent and typically had eighteen months to do so. See: Edward H. Lehner and David J. Sweet, "Goodman-Dearie Expiration Leaves Coop Conversions Radically Altered,” New York Law Journal, November 16, 1977.

${ }^{74}$ Biagio P. Riina to Michael Whiteman, June 4, 1974, Bill Jacket, L. 1974, ch 1021, New York State Archives.

75 Dearie, "The Conversion Game: The Newest Housing Crisis," 18. See also The Parkchesterite (Parkchester Tenants Association Newsletter), October 1973, 2 and various materials related to the New York Tenants Legislative Coalition lobbying in Ronald Lawson: Tenant Movement in New York City Research Files, TAM.214, Box 14, Folder "Parkchester Tenants Association," Tamiment Library/Robert F. Wagner Labor Archives, New York University.

${ }^{76}$ John J. Whalen, President of the Parkchester Defense Fund to Governor Malcolm Wilson, June 3, 1974, Bill Jacket, L. 1974, ch 1021, New York State Archives.

77 Attorney General Lefkowitz determined that Helmsley's plan to offer apartments for sale at Parkchester as they became vacant violated the new law, as he had not yet secured the approval of 35 percent of existing tenants. Robert E. Tomasson, "Parkchester's Conversion to Condominium Halted," New York Time, April 1, 1975 and "New Law Induces Helmsley to Delay Tudor City Change," New York Times, June 17, 1974.

${ }^{78}$ Quoted in Walter Rugaber, "Condominium Trend cuts Rental Market," New York Times, September 28, 1974.

79 Alan S. Oser, "Law Hampers the Switch of Rental Housing to Co-ops," New York Times, April $30,1976$.

${ }^{80}$ Condominium/Cooperative Study, Volume 1, 1.

81 "New Combination Condo-Cooperative Offers Flexible Financing and Marketing, Meets Instant Success," The Condominium Report, Volume 3, No 6 (July 1975).

${ }^{82}$ Quoted in Wendy Schuman, "Luxury Condominiums Attract Corporate Owners," New York Times, April 11, 1976. 
${ }^{83}$ Ibid.

${ }^{84}$ See: James R. Hudson, The Unanticipated City: Loft Conversions in Lower Manhattan (Amherst: The University of Massachusetts Press, 1987) and Sharon Zukin, Loft Living: Culture and Capital in Urban Change (Baltimore: Johns Hopkins University Press, 1982).

${ }^{85}$ Hudson, The Unanticipated City, 61.

${ }^{86}$ Ford, Housing Policy and the Urban Middle Class, 19-22.

${ }^{87}$ David Clurman, "Building Conversions a Survival Tactic for Owners, Lenders," New York Law Journal, November 10, 1976.

88 “Lefkowitz Ruling 'Legalizes' Co-Op Apartment Ownership in Soho Area,” Press release of the Office of Attorney General Louis J. Lefkowitz, The Metropolitan Council on Housing Records, TAM.173, Box 65, Folder “Coop/Condo Conversion 1975-1977 \#2,” Tamiment Library/Robert F. Wagner Labor Archives, New York University.

${ }^{89}$ Allan Talbot, "Preface" in Housing Policy and the Urban Middle Class, xix.

${ }^{90}$ Ives's comments originally appeared in the fall 1977 newsletter, but were reprinted in a subsequent issue. Brewster Ives, "The Douglass Elliman-Gibbons \& Ives Index,” Douglas Elliman-Gibbons \& Ives, Inc. Newsletter, Vol. 2, No. 1 (Winter 1978-79).

${ }^{91}$ D.K. Patton / Real Estate Board of New York to Governor Hugh L. Carey, July 1, 1976, Bill Jacket L. 1976, chapter 504, New York State Archives.

${ }^{92}$ Brewster Ives, Tenant-Owned Apartment Association, Inc. "Testimony before the New York State Assembly Standing Committee on Housing, March 11, 1977," Hearing files, New York State Standing Committee on Housing, Box 1, New York State Archives.

${ }^{93}$ Though the Democratic-controlled Assembly passed a three-year extension, it failed to pass the Republican-controlled Senate. Lehner and Sweet, "Goodman-Dearie Expiration Leaves Coop Conversions Radically Altered."

94 This included David Clurman who then headed the Condominium Committee of the New York State Bar Association. See David Clurman, Condominium Committee of the New York State Bar Association to Counsel of the Governor, July 13, 1976, Bill Jacket L. 1976, chapter 504, New York State Archives.

95 “A Housing Law Nobody Needs,” New York Times, March 21, 1977.

${ }^{96}$ Author interview with Marc Luxenberg, January 10, 2013 and "The CYNC is Born," Habitat Magazine, May 2007, 49. 
97 "Marc Luxemburg, President Council of West Side Cooperatives to Manhattan Media Corporation" April 14, 1978, Archives of the Council of New York City Cooperatives.

${ }^{98}$ Joseph P. Fried, "Conversion of Rental Apartments Ticklish Concern for Legislature," New York Times, April 8, 1977. See also Joseph P. Fried, "Future of Law Regulating Apartment Conversions to Condominiums and Cooperatives Debated at Hearing," New York Times, March 13, 1977.

99 "The Council of New York Cooperatives," The Manhattan Cooperator, Vol. 1., No 1, April 1, 1981, 2.

100 "Editorial: Integrating the Co-op Community," The Manhattan Cooperator, Vol. 1, No. 1, April 1, 1981, 2.

${ }^{101}$ David W. Dunplap, “400 Attend a Conference on Running a Co-op,” New York Times, October 18, 1982.

${ }^{102}$ Many of these new homeowners, however, had already been living in the city when they purchased an apartment. The Conversion of Rental Housing to Condominiums and Cooperatives, Appendix 1, 218. For an excellent overview of Koch's tenure as mayor, see Jonathan Soffer, Ed Koch and the Rebuilding of New York (New York: Columbia University Press, 2010).

103 "Text of Address Delivered by Koch at His Inauguration as Mayor of New York City," New York Times, January 2, 1978.

${ }^{104}$ Robert A. Kandel (Office of the Mayor Ed Koch) to Newton Avrutis, September 24, 1979, The Metropolitan Council on Housing Records, TAM.173, Box 67, Folder, "Coop/Condo Conversion 1978-79 \#3," Tamiment Library/Robert F, Wagner Labor Archives, New York University.

${ }^{105}$ See, for example, Michael McKee, "State Legislators Pass Group Funding, Reject Co-Op Protection Bill," City Limits, June-July 1980, 14. Koch, in 1981 eventually supported raising the percentage to 51, along with a few other additional tenant protections. This was no doubt because of growing demand from the city's tenants, but also likely because he came to believe that greater bargaining power during a conversion might induce larger numbers of tenants to purchase their apartments, thus ultimately facilitating more conversions. Koch announced he believed the change "would not retard the co-op movement" but would "make apartments more affordable, and give even more people a chance to make their own investment in their neighborhood and their cities." "Press Release: Office of the Mayor" May 4, 1981, Records of the New York State Attorney General's Office, Attorney General Subject Files, 1978-1998, Box 14, The New York State Archives.

${ }^{106}$ Previously, the 35 percent threshold applied to rent regulated tenants; the 1982 law that raised this amount to 51 applied to all tenants in residence. The bill also strengthened protections for 
seniors and handicapped tenants, significantly lengthened occupancy periods for non-purchasing tenants in eviction plans, and included strong anti-harassment protections.

${ }^{107}$ Michael McKee, "How the City Got a New Co-op Law," City Limits, August-September 1982, 26-28.

108 There were several major changes to rent protection laws during this time, the most significant of which was the Emergency Tenant Protection Act (1974). Vacated rent controlled apartments became rent stabilized. All apartments built after 1969 - which had previously been unregulated - also became rent stabilized.

${ }^{109}$ Mary Keefe, “The Rise of the Counterfeit Co-op,” City Limits, February 1990, 14-15, 17.

${ }^{110}$ Alan S. Oser, "Rest of Parkchester's Tenants Get Conversion Plan," New York Times, September 16, 1983.

111 “A Conversation with Robert Abrams,” Real Estate Reporter, April 1983, 9.

112 “The Real Estate Reporter Essay: Cooperative and Condominium Housing," The Real Estate Reporter, April 1983, 15.

${ }^{113}$ Laurie Johnston, “Co-Ops Leading Latest Renaissance in Brooklyn,” New York Times, October 16, 1979.

114 Thomas J. Lueck, "Homeownership at Record Level for New Yorkers," New York Times, June 10, 1991.

${ }^{115}$ Quoted in James Barron, "Tenants in Luxury Buildings Uniting to Press their Complaints," New York Times, January 20, 1980.

${ }^{116}$ Data compiled from: "Douglas Elliman Index," The Douglas Elliman Newsletter, Vol. 5, No. 1, Winter 1983 and "Douglas Elliman Index," The Douglas Elliman Newsletter, Volume 8, Number 1. Winter 1986.

${ }^{117}$ For condominiums outpacing new development of other forms of housing in the early 1980s, see: Lee A. Daniels, “Condominiums Take the Lead,” New York Times, November 28, 1982.

${ }^{118}$ Diane Henry, “Abrams Would Tighten Co-op Conversion Laws,” New York Times, May 23, 1981.

${ }^{119}$ Quoted in Walter H. Waggoner, "Brewster Ives is Dead at 81; A Leader in Co-Op Business," New York Times, May 7, 1985. 
"A Shelter Can Tip the Scales Sometimes": Disinvestment, Gentrification, and the Neighborhood Politics of Homelessness in 1980s New York City

Ariel Eisenberg

\begin{abstract}
In the 1980s, visible homelessness became one of the most pressing problems in New York City. While most New Yorkers expressed sympathy for the homeless, many of them also resisted efforts to site shelters and service facilities in their neighborhoods. But far from being simply a case of NIMBY (Not In My Back Yard) sentiment, protests over the placement of these facilities arose in the context of decades-long neighborhood movements against urban disinvestment, and the beginning of gentrification in some New York City neighborhoods. I argue that understanding this history is crucial to parsing the complex politics of anti-homeless facility protests in the 1980s, and to understanding the rise of "quality of life" policies that would govern many neoliberal urban spaces by the 1990s.
\end{abstract}

\title{
Keywords
}

Homelessness, NIMBY, disinvestment, gentrification, quality of life, New York City

\section{Acknowledgements}

Thanks to Themis Chronopoulos and Jonathan Soffer for their comments that strengthened this article, and to Sarah Camacho, Cindy I-Fen Cheng, Charles Hughes, Haley Pollack, and William Cronon for reading and commenting on early drafts.

\section{Author Biography}

Ariel Eisenberg is Assistant Professor of History and Interdisciplinary Studies at Kennesaw State University, where she teaches women's history and women, gender, and sexuality studies. She is currently writing a book entitled "Save Our Streets and Shelter Our Homeless": The Homeless Crisis in Urban America in the 1980s. 


\section{Introduction}

\section{URGENT. STOP DERELICT ASSESSMENT CENTER AT WEST 88 STREET. THIS WILL DESTROY RESIDENTIAL NEIGHBORHOOD. COMMUNITY BOARD 7 VOTES TONIGHT.}

On June 2, 1981, New York City Mayor Edward I. Koch received a wave of identical telegrams. Each urged him to reconsider the city's plan to open a "derelict assessment center" for homeless New Yorkers at the corner of West $88^{\text {th }}$ Street and Amsterdam Avenue, on Manhattan's Upper West Side. One telegram writer elaborated further on the damage the facility would inflict on the community, noting, "125 DERELICTS A DAY WILL CERTAINLY CAUSE MENTAL DISTRESS AND PERHAPS BODILY HARM TO THE YOUNGSTERS WHO LIVE HERE." ${ }^{1}$ Similar protestations arose in Harlem and in East New York, Brooklyn, where residents organized against the opening of municipal men's shelters in former public school buildings. "GET RID OF THE BUMS," proclaimed a sign held by one Harlem demonstrator. "WE WANT OUR COMMUNITY SAFE, CLEAN, AND FREE OF DISEASES FOUR OUR RAISING CHILDREN!!!!!"2 On the Upper West Side, residents successfully blocked the construction of the Derelict Assessment Center; but in Harlem and East New York the shelters for hundreds of homeless men remained. The sentiments and tactics of citizens in the Upper West Side, Harlem, and East New York were remarkably similar, but the differing outcomes of their protests reveal the divergent fates of these neighborhoods in the midst of the rising neoliberal economic and social order of 1980s New York City.

To many New Yorkers, the rising homeless population encapsulated the problems that plagued their city. As visible figures in the public spaces of New York, homeless people appeared to be both the cause and consequence of rising urban disorder. ${ }^{3}$ While most New Yorkers expressed sympathy for the homeless and urged the municipal government to provide aid and shelter to un-housed individuals, many of them also resisted efforts to site shelters and service facilities in their neighborhoods. As the words of neighborhood protesters demonstrate, many New Yorkers understood the people they called derelicts, bums, or, increasingly, "the homeless," as an undesirable group. This was particularly true of homeless men, whom many understood to pose a safety threat to women and children. Despite the similarity of protesters' rhetoric, however, their concerns were met with markedly different responses by the New York City municipal government. Even as community activism defeated the Derelict Assessment Center on the Upper West Side, Mayor Koch chastised neighboring Harlem for its "selfishness" in refusing to host a homeless shelter for several hundred men. Even as New Yorkers from a range of neighborhoods decried the urban disorder that they associated with the homeless, disparities in the racial composition, socio-economic status, and political power of different neighborhoods greatly affected the landscape of shelter and service provision in New York City.

The year 1981 marked the beginning of a turbulent time in the provision of shelter and services to un-housed people in New York City. The number of New Yorkers who lacked a permanent place to live was rising: In 1979, the city estimated that it served 9,000 men and 6,000 women per year; by November of 1983 municipal shelters provided 
beds to almost 15,000 men, women, and children per month. ${ }^{4}$ Homelessness had, by many accounts, reached crisis proportions. ${ }^{5}$ Yet how to assist this growing population and where to do so - was the source of growing controversy. The Koch administration sought to use city armories and shuttered public schools and hospitals to provide temporary shelter to a population whose numbers - Koch presumed - would soon diminish. But few New Yorkers wanted to take on a large public shelter, even temporarily: In 1981, every local community board rejected the city's efforts to place a 200- to 300-bed men's facility in its area of jurisdiction, and local residents protested the city's plans on the streets and in the courts. ${ }^{6}$ In 1982, a frustrated Koch proclaimed that an "outbreak of selfishness" had taken hold among city residents. Citing the protests that had occurred in the last year over city projects including the opening of a men's shelter in Harlem, Koch chastised, "Communities raise their hands not to volunteer, but to point somewhere else. Build it over there...not here."7 The New York Times concurred, noting that if New Yorkers seemed in agreement about one thing, it was the sentiment, "Keep them out of $m y$ neighborhood." 8

Scholars and journalists have traced a transition in public sentiment about homelessness from one of sympathy in the early 1980s to disgust and frustration by the late 1980s and early 1990s. Kenneth Kusmer, for instance, remarked that the earliest years of New York City's homeless crisis were a time of "widespread empathy" for unhoused people. By the late 1980s, according to this narrative, shock and despair had largely transformed into "sympathy fatigue," as New Yorkers became increasingly intolerant of visibly un-housed people in the streets, parks, and public transit terminals of the city. ${ }^{9}$ In their 2010 review of recent scholarship on homelessness, Barrett A. Lee, Kimberly A. Tyler, and James D. Wright noted several studies that found that the tone of media coverage on homelessness changed in the late 1980s from "positive" to "somewhat harsher," with "more stories on the deviance of homeless persons, the disorder they create, and the steps being taken to deal with them." 10 This shift in public opinion and media representation is especially important in light of the corresponding political shift: After decades of Democratic leadership, Republican Rudolph Giuliani was elected Mayor of New York City in 1993 on a "quality of life" platform to curb (among other things) panhandling, sidewalk vending, and public sleeping - all hallmarks of "homeless" behavior in New York City. ${ }^{11}$

Early 1980s struggles against the siting of homeless shelters and facilities, however, defy this conventional dichotomy between the early homeless crisis and its later years. Even as New Yorkers called upon the city to help the homeless, they also protested the presence of homeless people and the facilities that served them. Their complaints centered upon the embodied qualities that homeless people laid bare in the city's public spaces, including begging, sleeping, and urinating. These protestations reveal ambivalent sentiments towards the homeless: most often, sympathy was tinged with frustration, fear, or disgust, even in the earliest years of the crisis. As Greenwich Village resident Ruth Rosenberg wrote about her encounters with homeless street people in 1981, "my own revulsion [is] followed by feelings of pity and compassion."12 Frustration with visibly homeless people and strategies to minimize their presence existed side by side with sympathy: Both were a part of the fabric of the homeless crisis since its earliest years.

However, protests revealed more than just the sympathy and disgust of New York City residents towards visibly homeless people. Neighborhood opposition to homeless 
facilities was often rooted in a deeper frustration towards a city that had, for years or even decades, concentrated "undesirable" services in neighborhoods that already suffered the worst effects of municipal disinvestment. Indeed, struggles against homeless facilities took place in an urban environment that had been the site of pitched battles against municipal disinvestment and for greater community control of neighborhood institutions. ${ }^{13}$ For instance, Upper West Side residents had long decried the municipal and state governments' use of the neighborhood's single room occupancy (SRO) apartments to house poor and deinstitutionalized people without providing adequate social services for those populations. In East New York, Brooklyn, a predominantly poor African American neighborhood that suffered severe housing abandonment in the 1970s, the city installed several large congregate shelters without community input, and failed to provide adequate staffing for the shelter or social services in the area surrounding it. In fact, the city placed the vast majority of homeless shelters and service facilities in majority poor, non-white neighborhoods in the 1980s. ${ }^{14}$ As Joel Blau and Alex S. Vitale have separately noted, many communities were justifiably frustrated with the municipal government's haphazard and inequitable shelter policies. Vitale argues that even liberal AfricanAmerican East New Yorkers eventually embraced "quality of life" politics because the city had for so long failed to address the problems that had grown worse in their neighborhood. ${ }^{15}$ In East New York, Harlem, and the Upper West Side, community members feared that a homeless facility was simply another sign of the city's lack of investment in their neighborhood. As one West Sider implored the mayor in 1981, "stop using the West Side as a dumping ground." "These words imply that while homelessness was a new phenomenon, the practice of siting undesirable facilities in underprivileged neighborhoods was not.

Historians of homelessness have thus far tended to focus their studies on the first half of the twentieth century, and have not yet closely examined not-in-my-back-yard struggles or the New York City homeless crisis, more broadly. ${ }^{17}$ Social scientists have frequently examined the causes of NIMBY struggles, both in general and as they relate to the homeless in particular. ${ }^{18}$ A recent article by John C. Kilburn, Stephen E. Costanza, Kelly Frailing, and and Stephanie Diaz on NIMBY battles in "decaying communities" provides especially pertinent insight on the attitudes of long-term neighborhood residents towards social service facilities and their clients. ${ }^{19}$ Kim Hopper has hypothesized that NIMBY opposition "may have nothing to do with the specificities of proposed programs or housing, and everything to do with entrenched patterns of eroding local control," and Jennifer Wolch and Michael Dear similarly noted that homeless shelter opposition was related to the economic inequality and geographical segregation that characterized many late-twentieth century U.S. cities. ${ }^{20}$ With the exception of Hopper, few of these authors have examined change over time as it relates to homelessness, and many who have written about intolerance of homeless people attribute it to the aforementioned "sympathy fatigue." Examining NIMBY battles from the early 1980s demonstrates that many of the same complex sentiments existed then. Far from being the result of sympathy fatigue in the 1990s or the election of Mayor Rudolph Giuliani in 1993, these attitudes originated in the early 1980s (or earlier), and were embodied in neighborhood NIMBY struggles. By examining the conflicts over homeless shelters and service facilities in the Upper West Side, Harlem, and East New York, this complex history become visible. 
In some ways, these three neighborhoods were similar: they all had sizable poor and working-class non-white populations; they all had a high concentration of old, lowincome housing stock; and they had all suffered from some degree of municipal neglect and commercial disinvestment dating back a decade or longer. But crucial differences existed between the three neighborhoods. Unlike Harlem and East New York, which were predominantly low-income and black, Manhattan's Upper West Side neighborhood was gentrifying. It had a sizable - and growing - population of white residents, and its median income level was well above that of neighboring Harlem. Developers were buying and renovating Single Room Occupancy apartments and other low-cost residential properties. New higher-end businesses were opening. ${ }^{21}$ On the Upper West Side in particular, the New York Police Department was putting more effort into policing the types of petty crime and misdemeanors - including street corner drug dealing and public drinking - that would, by 1993, come to be defined as "quality of life" issues by future mayor Rudolph Giuliani. ${ }^{22}$

Disparities in wealth, geography, and political power affected the outcome of notin-my-back-yard struggles over homelessness. As Ella Howard has noted, most of the city's visibly homeless population was concentrated in Manhattan's Bowery until the 1970s, when the neighborhood began to undergo gentrification. ${ }^{23}$ Due to dispersal on the Bowery as well as local housing change, the Upper West Side had a sizable population of visibly homeless individuals by the 1970s; in contrast, Harlem and East New York had little, if any, visible homelessness. But in terms of wealth and housing prices, the Upper West Side far exceeded its neighbor, Harlem: by 1985, the Upper West Side's median income was \$23,006, whereas in Harlem it was \$7,071. Rental housing in Harlem was far less expensive than on the Upper West Side, and Harlem residents were far more likely to live near abandoned or dilapidated buildings than were Upper West Side residents. A similar situation developed in East New York, which was demographically like Harlem. By the mid-1980s, shelters for several hundred men had opened in Harlem and East New York, while Upper West Side residents succeeded in halting the city's plans to locate a facility for homeless men in their neighborhood. While activists in each neighborhood understood their struggles against homeless facilities as necessary self-advocacy in the face of injustice, the disparate results of anti-homeless service protests demonstrate the diverging courses of the Upper West Side, on the one hand, and Harlem and East New York, on the other, in a changing city. ${ }^{24}$

\section{The Upper West Side}

The historical complexities undergirding struggles against homeless facilities is most vividly illustrated in the case of the Derelict Assessment Center in Manhattan's Upper West Side neighborhood. The impetus for the center's creation in June of 1981 was not Callahan v. Carey (the historic decree mandating that the municipal government provide shelter to all homeless men was not signed until August of that year), but rather a

state initiative to provide funds for the care of former patients of psychiatric institutions. ${ }^{25}$ The center would assist the "thousands of vagrants and former mental patients" who, according to a 1981 New York Times article, were "visible all over the West Side."26 Rather than directly provide shelter, the Assessment Center would provide showers and meals to its clients, and would be staffed by social workers equipped to help clients 
access drug and alcohol recovery programs, psychiatric treatment, emergency shelter and permanent housing.

Upper West Side residents quickly moved to protest the city's plan. The telegrams and letters that Mayor Koch received in the weeks and months following Community Board 7's meeting - in which the board approved the Derelict Assessment Center suggested that the new center would compromise the stability of the surrounding neighborhood and the safety of its inhabitants. These letters provided few details of the danger "derelicts" were thought to cause; instead, protestations revolved around the embodied presence of un-housed people as a population that did not conform to residents' aspirational views of the neighborhood. For instance, Doug and Dana Wyles wrote, "While as long-time West Siders, we agree that such services are necessary, we feel that they would be better located in a commercial neighborhood. Ours is a solidly upwardly mobile middle class neighborhood with many children.",27

The process, however, by which the neighborhood acquired its "solidly upwardly mobile middle class" population was far from organic. Rather, it was largely the result of the previous three decades of urban renewal, and the citizens' activism that surrounded it. $^{28}$ The West Side Urban Renewal Area (WSURA), one of New York City's most ambitious urban renewal projects, spanned a twenty-block stretch from West $87^{\text {th }}$ to West $97^{\text {th }}$ Streets, Amsterdam Avenue to Central Park West. Had it been completed, the project would have included a mix of high, middle, and lower-income residences in an area that the city had long classified as a slum. ${ }^{29}$ But the neighborhood's growing population of white middle-income residents contested the city's plan, arguing that low-income housing would negatively affect the character of the Upper West Side. ${ }^{30}$ In a lawsuit that extended over the 1970s, a group called CONTINUE (Committee of Neighbors to Insure a Normal Urban Environment) contended that the development of public housing in the WSURA would violate the federal Department of Housing and Urban Development's guidelines on maintaining the natural and social environment of a neighborhood. As lawyer and housing advocate John Douw observed, this amounted to arguing that poor people were an "environmental hazard," and not part of the "normal urban environment." 31

The specter of mental illness also informed Upper West Side residents' protestations. By the 1970 s, the city and state governments had increasingly come to rely upon the Upper West Side's abundant supply of single room occupancy (SRO) apartments to house mentally ill and intellectually disabled people who might have once been institutionalized. One organization, the West Side Community Task Force on Single Room Occupancy Housing, claimed that "former patients were, in some instances, literally transported in buses to our neighborhood and dumped into SRO hotels," where they were then left to "wander the streets of Broadway." The Task Force's report vacillated between describing this population as helpless and dangerous: they were both "preyed upon by criminals" and also criminals themselves, implicated in the neighborhood looting that followed the citywide blackout of July $1977 .{ }^{32}$ With little proof of this connection, though, it seemed that most of the threat SRO residents posed to the Upper West Side came in the form of their bodily and behavioral difference.

Upper West Siders' responses to the proposed Derelict Assessment Center bore the marks of this history; their letters to Mayor Koch reveal the extent to which they believed the neighborhood's character was threatened by a facility for homeless and 
marginally housed people. ${ }^{33}$ Francis Lackner, for instance, wrote that the center would "drive out those who are attempting to improve and invest in this depressed neighborhood." 34 Others expressed their fears that the center "will lead to many disruptions at a time when the West Side is beginning to take pride in itself and people are feeling optimistic," or, more bluntly, that the center would ruin "what is now one of the few livable residential areas in Manhattan." ${ }^{, 35}$ Reactions to the presence of homeless people on city streets existed along a historical continuum that singled out poor people as undesirable neighbors, and as illegitimate presences in public space. Upper West Side residents understood poor people as destabilizing forces in their community, and feared that the Derelict Assessment Center would lead to the dereliction of the neighborhood itself.

Few could point to any concrete examples of criminal behavior. What they could - and did - point to again and again was bodily disorder: the homeless were "half naked"; they "wandered the streets," aimless and sometimes delusional; the scent of urine and feces clung to their bodies; they were, in the words of one letter writer, "human pollution." ${ }^{36}$ Susan Levin argued that the "physical and mental problems," as well as the "skin ulcers, dirt, and lice so many homeless people exhibit" needed to be treated in a "medically-oriented setting" for which the Derelict Assessment Center was inappropriate. ${ }^{37}$ And Doug and Dana Wyles warned the mayor that the center would increase the prevalence of hepatitis in the neighborhood. ${ }^{38}$ The real danger of derelicts, then, lay in their bodily misbehavior: public defecation and sleeping; unwashed appearance and odor; and delusional-seeming language and actions. The danger lay in the very fact of homeless people's unsheltered existence and the embodied qualities it laid bare in the city's public spaces. ${ }^{39}$

As municipal documents and citizens' letters attest, homeless men were the most frequent focus of neighborhood residents' fears. In her letter opposing the Derelict Assessment Center, Susan Levin chided Mayor Koch for his misleading characterization of the center's potential clients, noting, "You spoke of a place for 'shopping bag ladies,' an accurate description of only some of the clients at the Amsterdam Center." Homeless men, she added, were "hostile and violent." Edith Rosenstock wrote to Mayor Koch that "Children who attend school and elderly people like ourselves want to feel safe." And one anonymous parent wrote, "Having a teen age daughter that must go to school thru this area...worries me." 40 None of the letter writers explicitly stated what fate might befall those who would have to walk past the Derelict Assessment Center, yet their words imply that the center's clientele could inflict violence upon groups typically thought of as vulnerable, including children, young women, and the elderly. ${ }^{41}$

Upper West Side residents further feared that the Derelict Assessment Center would make their neighborhood a "dumping ground for the entire city." "42 One wrote of how the center would "collect homeless people" and lead to the "traumatization" of the neighborhood. Such comments implied that the center would bring outsiders into the community, making the Upper West Side, as one resident put it, "a gathering place for undesirables." ${ }^{, 43}$ Such descriptions suggested that the clients being served by the center would be outsiders to the community, but a letter from Minnie Horowitz suggested otherwise: She referred to the center's potential clients as the "vagrants, alcoholics, and former mental patients who roam the streets of the West Side." ${ }^{, 44}$ Even as her words acknowledged the presence of impoverished people residing in the neighborhood, they 
also drew a line of demarcation between those whose presence in the neighborhood was suitable or legitimate and those who simply "roam" it.

Like most New Yorkers, the Upper West Siders protesting the Derelict Assessment Center recognized that the city's unsheltered people "desperately need help." But they urged the city to find a different neighborhood in which to provide that help. "Couldn't the Center for these unfortunate people... be put in a non-residential neighborhood?" asked Edith Rosenstock. ${ }^{45}$ Another person bluntly wrote, "I am a resident of West $87^{\text {th }}$ Street, and I am opposed to having an assessment center in the middle of a residential neighborhood. "46 Minnie Horowitz articulated this mix of sympathy for the homeless and protectiveness for her neighborhood when she wrote, "this Center - to service perhaps thousands of these unfortunates - would be destroying what is now a good and fairly safe neighborhood." 47 As much as Upper West Side residents recognized the need for facilities to serve the city's growing population of unhoused and tenuously-housed people, they also drew upon a long history of envisioning the Upper West Side as an embattled neighborhood which needed to be preserved for middle-class residents.

The city never built the Derelict Assessment Center. The precise reasons are unclear, as neither newspaper nor archival documents followed the struggle to its conclusion, but it seems probable that the activism of neighborhood residents had a hand in defeating the center. However, it is also likely that the municipal government recognized that the Upper West Side was in fact a community in transition, and that the forces of gentrification were turning it from a "service ghetto" into a "solidly upwardly mobile middle class neighborhood," even though such a transition was by no means complete in 1981. The municipal government recognized that the days when the Upper West Side was a "service ghetto" for the city were coming to an end.

Mayor Koch delivered his speech on New Yorkers' "outbreak of selfishness" over one year after the protests against the Derelict Assessment Center. ${ }^{48}$ Homeless shelters and services often took center stage during this period as the city's homelessness rate continued to rise dramatically and as the city government struggled to fulfill the mandate of Callahan v. Carey. At the moment of his speech, Koch was particularly incensed by protests in Harlem against a men's shelter the city opened in the building that had formerly housed Public School 156 on Eighth Avenue and $155^{\text {th }}$ Street. But he no doubt also had in mind two other recent protests: One in East New York, Brooklyn, where residents had demanded that the city shutter a hastily-opened congregate men's shelter in the old Public School 63 building; the other in the former Sydenham Hospital building on Manhattan Avenue in Harlem, which itself had been the site of a fierce battle over the city's decision to close the hospital's doors fewer than two years earlier. The rhetoric of these protests did not differ substantially from that of Upper West Side residents protesting the Derelict Assessment Center, but the city's response to the protests - and the eventual outcome - demonstrate the differences that existed between the neighborhoods.

\section{East New York}

After the August 1981 signing of the Callahan v. Carey consent decree, East New York was the first neighborhood to experience upheaval. On October 21, 1981, HRA opened a 400-bed men's shelter at P.S. 63, an elementary school that the city had closed 
the previous year. The city claimed that the decision to use the building as a shelter was a last-minute one, spurred by a Manhattan Supreme Court judge's order just one day earlier that the city must immediately create a facility for the hundreds of men who were still not adequately sheltered. Yet East New York residents suspected otherwise: At a communitywide meeting in early November, residents noted that the city had carefully maintained the building since its closure the previous year, leading Jack Deacy, deputy commissioner of public affairs for HRA, to admit that the building had in fact been "under active consideration" as a shelter site for some time. ${ }^{49}$

In a retrospective interview, Koch's deputy mayor Nathan Leventhal conceded that in the early 1980s, the city's tactics for opening shelters were often secretive and swift:

... Nobody wanted homeless shelters, which they don't today either, but they were really refusing. Forget it...So what I did is I - we opened homeless shelters regularly at two in the morning. And I would usually tell the borough president in advance and they would say, 'Fine, do what you have to do and then I'll blast you in the papers the next morning.' I said 'fine.' And so that's how we did it...We'd take schools, under-utilized schools. It was a real emergency kind of situation. ${ }^{50}$

Leventhal's blunt reminiscence confirmed what East New Yorkers had suspected: the city had planned to place a shelter in their community without consulting them. While Leventhal's words indicate that early-morning covert shelter openings became standard operating procedure for the city, they stand in sharp contrast to the prolonged process of debate and bureaucratic procedure that preceded the (failed) opening of the Derelict Assessment Center on the Upper West Side just a few months earlier. There, the Derelict Assessment Center was subjected to the (non-binding) approval of the neighborhood's community board, which had the effect of alerting community members to the plan, giving them time to mobilize before the center's opening. No such transparency existed with the East New York men's shelter: Neighborhood residents - including members of local Community Board 5 - learned of its opening after the fact, leading one shocked neighborhood resident, Clint Wike, to describe himself as "an angry parent," noting, "this was dumped on me without me having any say.",51

To many East New Yorkers, the city's covert tactics represented more than simple ineptitude: They also signaled the city's lack of respect for or interest in the future of the neighborhood, confirming a decades-long pattern of discrimination and neglect. East New York experienced a trajectory similar to many urban neighborhoods in the United States following World War II. A combination of white flight, bank redlining, discriminatory federal loan policies, residential segregation enforced by realtors and landlords, and commercial and governmental disinvestment left the neighborhood's housing stock and infrastructure decrepit, and its mostly black and Latino residents with few options for geographical mobility or economic advancement. By the late 1960s, the neighborhood was in a state that historian Walter Thabit described as "almost total collapse." 52

This legacy was by no means a thing of the past in 1981, as residents were all-tooaware. As one East New Yorker put it, "There's a complete lack of city services in our area: street lights are out, potholes are all over the place, sanitation facilities are shot, and 
our park is completely devastated, and people are afraid to walk out in the streets after dark." 53 A number of neighborhood associations had worked for years - with virtually no assistance from the city - to improve East New York's housing stock and to create programs that would support the community. Since the closing of P.S. 63 in 1980, local civic leaders had been moving forward with plans to use the building as a headquarters for an East New York business development corporation, which they hoped would spur the area's economic improvement. But as C. Moore, president of the local Bedford Friendship Block Association, noted after the shelter's opening, "Nobody wants to come to East New York now." ${ }^{54}$ East New Yorkers had long been working to reverse the tide of commercial and municipal disinvestment from their neighborhood; but the shelter, they feared, was a calamitous roadblock on the fraught path to neighborhood recovery.

\section{Harlem}

The next year, a similar scenario unfolded in Harlem when the city opened a 200bed facility for homeless men in the recently closed P.S. 156 building. Like the closure of P.S. 63 in East New York, the closure of P.S. 156 in Harlem was merely the latest episode in a trajectory of municipal disinvestment that had characterized the historically black neighborhood for decades. ${ }^{55}$ Harlem residents organized continuous protests outside of the facility, eventually compelling city officials to meet with them. The meeting was fruitless, however, as Mayor Koch declared that Harlem residents would have to convince him that the city's decision to place a shelter in their neighborhood was "wrong," a task at which he apparently doubted they would succeed. And in fact, the shelter remained. ${ }^{56}$

At protests against the P.S. 156 shelter, Harlem residents cited community safety as a primary reason that they opposed the shelter. Its location near a public school and two public housing developments was a particular sore point, as parents and concerned community members urged Mayor Koch to consider the safety of neighborhood children. Outside the shelter, one protestor's handwritten sign summed up the sentiment: "GET RID OF THE BUMS. WE WANT OUR COMMUNITY SAFE, CLEAN, AND FREE OF DISEASES FOUR OUR RAISING CHILDREN!!!!!"57 Such protestations are virtually indistinguishable from those of the Upper West Side community members who, just one year earlier, cited neighborhood vitality and their children's safety as their primary reasons for objecting to the Derelict Assessment Center.

In both Harlem and East New York, as on the Upper West Side, neighborhood residents viewed homeless men in particular as a threat. Residents cited the potential for crime and violence that they feared the shelters' clientele would bring to their respective neighborhoods. State Senator Major Owens, whose district included East New York, accused Mayor Koch of mischaracterizing the shelter's population as "harmless, homeless old men." As the New York Amsterdam News article that quoted him clarified, such characterization "is a deliberate falsification of the reality of the situation. Many of the men are neither old nor harmless," but in fact "alcoholics, drug addicts and/or mentally ill young men." 58 At a meeting to discuss the P.S. 156 shelter in Harlem, the Reverend Lawrence E. Lucas, pastor of Resurrection Church, had even stronger words. Speaking against Koch's assertion that he would wait to be proven wrong on the decision to open the shelter, Lucas asserted that what Koch really meant was, "If you show me some dead kids and raped kids, then I will reconsider., 59 
In neighborhoods across New York City - neighborhoods that spanned the racial and socio-economic spectrum - homeless men were understood as a particular risk. Their bodies were associated with disease, addiction, and criminal and sexual deviance. Further, both Harlemites and East New Yorkers - like Upper West Siders - understood homeless men as foreign threats that infiltrated their communities. Just as Upper West Siders worried that a Derelict Assessment Center would make their neighborhood a "dumping ground" for the entire city, so too did Harlem and East New York residents understand the homeless being brought to newly-opened shelters in their neighborhoods as outsiders. In East New York, local activist and former conservative Republican state assemblyman Vito P. Battista accused the city of trying to "get all the homeless men off the Bowery so they can put high-rise buildings there. ${ }^{.60}$ In Harlem, protests against another proposed men's shelter in the building that had formerly been Sydenham Hospital leveled similar accusations at the city. A group calling itself Community Residents of Harlem distributed a flier proclaiming that a men's shelter at Sydenham "will mean destruction to the Harlem community."

This crazy plan will bring over 400 drug addicts, rapists, killers and mental rejects to the Harlem community. The Outsiders, mostly white homeless men, will be transported by buses from the Bowery to Sydenham.

The characterization of the shelter's clientele as white served to reinforce the men's outsider status in relation to the majority black Harlem community. Whether or not the characterization was based in fact (and it was most likely not, as New York's homeless population was, by 1982, increasingly comprised of black men), it highlights the extent to which many Harlem residents believed their community to be under siege by the municipal government. It also is merely one component of the broader racial analysis groups like Community Residents of Harlem made. Their flier continued,

HARLEM NEEDS DECENT HOSPITALS, DECENT HEALTH CARE
FACILITIES, AND DECENT HOUSING - NOT A CRIME RIDDEN
DESTRUCTIVE MEN'S SHELTER. The Men's Shelter for the
Sydenham building is a plan devised by Mayor Koch as a vindicted (sic)
way of punishing the Blacks for voting against him for Governor. He
selected Sydenham because it is symbolic to Blacks throughout New York
State...WHY SHOULD THE HARLEM COMMUNITY BE
OVERCROWDED WITH THE OUTSIDE HOMELESS MEN AND THE
WHITE COMMUNITIES ARE EXCLUDED AND PROTECTED FROM
THE HOMELESS? It is okay to destroy the Black communities by racist
standards. It should be noted that all of the City shelters are located in
Black and Puerto Rican communities.

Harlem residents had good reason to feel that they were being punished by the municipal government: Since Koch's election in 1978, little had changed in their neighborhood, even as neighboring communities began to see improvement. Instead, areas like Harlem and East New York watched as developers began to renovate residential buildings and as 
new businesses opened in other neighborhoods. In addition, most of the schools and hospitals the city closed in the interest of fiscal "austerity" after 1975's near-bankruptcy were in low-income neighborhoods of color. ${ }^{62}$ Sydenham was just one such site; in Harlem the municipal government had also closed Logan Hospital and re-purposed Metropolitan Hospital as an addiction treatment facility, thus taking away the emergency services and clinics upon which many uninsured Harlemites (as well as those insured by Medicaid, which many private hospitals and doctors did not accept) had relied for medical care. Thus, as communities like Harlem and East New York were losing vital services, they were gaining facilities like congregate homeless shelters that drastically altered the population and landscape of their neighborhoods.

In a memo to mayoral staff member Clark Whelton, Koch emphasized his "contempt" for those protesting city shelter sites, including a neighborhood priest. He contemplated writing an opinion piece for a local newspaper in which he asks Reverend Lucas, "Father, 25 days before Christmas and no room in the inn?" invoking the biblical story of Jesus's birth in a manger after his homeless mother, Mary, was turned away by an innkeeper. ${ }^{63}$ The editorial staff of the New York Amsterdam News offered a more nuanced analysis of the issue that Koch was willing to give. "The Harlem residents who are demonstrating against the use of P.S. 156 are outraged because they feel that their neighborhood was chosen as a site for a shelter without regard for their views," the editors noted. "It would," however, "be shameless for anyone to suggest that the homeless by definition are undesirable and therefore unwelcome." ${ }^{64}$ This sentiment was echoed in several letters to the editor, where readers urged Harlem residents to rise to the occasion ("The mayor has presented us with a challenge and an opportunity to turn despair into triumph," wrote Mrs. Julian Jordan), and, more cynically, to direct their protest towards other, more pressing concerns, such as the prison work release programs located in Harlem, and to accept a new homeless shelter. ${ }^{65}$

But Harlemites' accusations of racism could hardly be dismissed out of hand: Of the six city-run homeless shelters in New York City in 1982, four were in majority poor, majority non-white neighborhoods, and one other was on Ward's Island, which had no residential population. ${ }^{66}$ And many politicians, civic and religious leaders agreed with local residents that racial bias motivated the siting of homeless shelters in New York City. As Reverend Lucas asked at the public meeting on the P.S. 156 shelter, "Why do all the jails have to be in Chinatown, and why do all the shelters have to be in Niggertown or Spictown?"67

\section{Conclusion}

Reflecting in February 1983 on the heated anti-shelter battles that had characterized the previous two years, David J. Stern, executive director of the Upper East Side's Neighborhood Coalition for Shelter, noted, "When Harlem protested, they were fighting for neighborhood survival." The previous month, the city of New York had opened a men's shelter at the Upper East Side's Seventh Regiment Armory, and Stern's Neighborhood Coalition for Shelter had been instrumental in mobilizing community support. No protests accompanied the shelter's opening; in fact, community members had welcomed the homeless men with donations of clothing and pastries. Though Stern admitted that he had "no easy answers" for why residents of the wealthy, predominantly white Upper East Side responded so affirmatively to the new shelter, he hypothesized, "A 
shelter can tip the scales sometimes. It's not going to tip the scales on the Upper East Side. People here are not going to flee because of a shelter." 68

The idea that a facility for homeless men would "tip the scales" in a less secure area, leading to (or reinforcing) its decline, did indeed seem to inform the fears of New Yorkers in Harlem, East New York, and the Upper West Side. As Stern acknowledged, neighborhood stability was one key factor in the successful integration of a homeless shelter: If community members felt that their neighborhood was secure and well cared for by citizens and city, fears of its demise might be less likely to arise. Community involvement was another factor: The opening of the shelter at the Seventh Regiment Armory marked the city's first successful attempt to collaborate with community members on the opening of a facility for the homeless. Upper East Siders had also previously been involved in the creation of a private shelter for homeless women, and Stern hypothesized that that first positive experience "made it easier for the armory shelter to work." Facilities for the homeless were not - Stern's comments implied particularly desirable, and yet their presence did not have to mean the death of the surrounding neighborhood.

The Upper East Side's experience, however, was an exception to the rule. As Stern noted, the neighborhood's location, demographics, and history of homeless aid efforts made it vastly different from other neighborhoods. ${ }^{69}$ Throughout much of the 1980 s, the municipal government continued to open shelters using the policy that geographer Sharon Lord Gaber labeled "sneak "em in," opening (or attempting to open) multiple shelters without notifying community members or community boards. ${ }^{70}$ The municipal government clearly did not apply its homeless policy equally in all neighborhoods, but rather weighed the political costs and benefits of working with - or ignoring - community members' interests.

Residents across New York City reacted with both sympathy and disgust to the increased presence of un-housed people in public space, and anti-shelter protests reflected this ambivalence; but protests also stemmed from many New Yorkers' deep distrust of and frustration with the municipal government. Mayor Koch's condemnation of antishelter protests as an "outbreak of selfishness" grossly mischaracterized the situation. As City Limits analyzed in a special 1987 issue entitled "The NIMBY Dilemma,"

Unlike Koch's older technologies - like calling his opponents 'wackos,' NIMBY is subtle and lethal. It is a kind of verbal neutron bomb that allows the mayor's policies to remain standing, while decimating all serious criticisms of his wasteful and wrongheaded housing and homeless programs and obscuring the merits of alternative programs proposed by critics. NIMBY undermines the credibility and honesty of his opponents, portraying them as narrow, mean, and self-interested. ${ }^{71}$

Indeed, housing and homeless advocacy groups - including the Coalition for the Homeless, the organization founded by Robert Hayes, the lead lawyer in Callahan $v$. Carey - remained critical of the Koch administration's tactics to shelter homeless New Yorkers. Throughout the 1980s, the city continued to open large congregate shelters in low-income, non-white neighborhoods with little warning to or dialogue with the surrounding community. ${ }^{72}$ 
Examining protests against homeless facilities provides crucial insight into some of the most dramatic changes taking place in cities in the late twentieth century. In the wake of decades of disinvestment, and on the cusp of New York City's rapid but uneven gentrification, these protests revealed city residents' desires to make their communities safer and more livable, and their frustration with the negligence of the municipal government. By identifying homeless people and the facilities that served them as problems in need of solving, protests also foretold a growing phenomenon in urban areas around the country, where the removal of undesirable behaviors, bodies, and facilities was equated with the improvement of "quality of life." Although the term "quality of life" is most famously associated with New York City Mayor Rudolph Giuliani (19932001), Ed Koch had used the term since early in his mayoralty; it guided the Koch administration's understanding of how to both formally and informally police the people and acts they considered to be public nuisances. Striking a balance between promoting "quality of life" or "urban civility" and staying within (or cautiously testing) the legal parameters of individual civil liberties appeared to be a constant focus of members of the Koch administration. ${ }^{73}$ Considering the contexts in which anti-shelter protests took place is thus crucial to understanding the specific circumstances that led activists on the Upper West Side, in East New York, and in Harlem to confront homelessness and attempt to shape the future of their respective neighborhoods. It is also crucial to understanding the politics of class, race, and geography that would be embodied by many in New York City - and cities around the United States - by the late twentieth and early twenty-first centuries. 


\section{Notes}

${ }^{1}$ New York City residents to Mayor Edward I. Koch, June 2, 1981, Mayor Edward I. Koch Collection, General Correspondences, Box 3, Folder 10, Municipal Archives of the City of New York (hereafter MACNY).

${ }^{2}$ Thea Breite, “Harlem to Koch - 'No Homeless Here'," Uptown, December 8, 1982, 1.

${ }^{3}$ As Kim Hopper has argued, the homeless in 1980s New York City actually signified disorder. Kim Hopper testimony, January 14, 1992, Public Meetings of the Commission of the Homeless (aka "The Cuomo Commission), Box 2, Mayor David Dinkins Collection, MACNY.

${ }^{4}$ The year 1983 was the first year for which comprehensive shelter statistics were available. The city did not keep statistics on transgender or gender non-normative people. For the 1979 number, see Kim Hopper, Reckoning With Homelessness (Ithaca, NY:

Cornell University Press, 2003), 61; for the 1983 number, see "New York City Homeless Municipal Shelter Population, 1983-present," Coalition for the Homeless, accessed July 2014, http://coalhome.3cdn.net/0178751adf01c4b465_fom6ivqne.pdf.

${ }^{5}$ A 1983 report by New York's Coalition for the Homeless, for instance, contended, "There is little dispute that homelessness has reached crisis proportions." Cruel Brinkmanship: Planning for the Homeless - 1983 (New York: Coalition for the Homeless, 1983), 3. See also Deirdre Carmody, "New York Is Facing 'Crisis' On Vagrants," New York Times, June 28, 1981, 1.

${ }^{6}$ Deirdre Carmody, 'New York Is Facing 'Crisis' On Vagrants,' New York Times, June $28,1981,1$.

${ }^{7}$ Maurice Carroll, "Koch Discerns an Outbreak of Community Selfishness," New York Times, December 18, 1982, 29. Koch referred in his speech not only to anti-shelter protests, but also to protests over the construction of a jail in Chinatown, a waste treatment facility in Brooklyn, and low-income housing on the Upper West Side. An internal memorandum Koch wrote to an aid refers solely and explicitly to the Harlem protests: Edward I. Koch to Clark Whelton, Mayor Edward I. Koch Collection, Box 90, Folder 11, New York City Municipal Archives.

8 “If Not Here, Where?” New York Times, November 27, 1982, 22.

${ }^{9}$ Kenneth Kusmer, Down and Out, On the Road: The Homeless in American History (New York: Oxford University Press, 2002), 246. For other examples of this narrative in scholarship, see: Samira Kawash, "The Homeless Body," Public Culture 10:2 (1998), 326 (footnote 7); Don Mitchell, "The Annihilation of Space by Law: The Roots and Implications of Anti-Homeless Laws in the United States," Antipode 29:3 (July 1997), 326; Neil Smith, The New Urban Frontier: Gentrification and the Revanchist City (New 
York: Routledge, 1996), 210-232; Neil Smith, "Which New Urbanism? The Revanchist '90s," Perspecta 30 (1999), 98-105. For some media reports on sympathy fatigue, see: Fox Butterfield, "New Yorkers Growing Angry Over Aggressive Panhandlers," New York Times, July 29, 1988, A1; Barbara Day, "Is NYC's public becoming more intolerant of the homeless?" New York Amsterdam News, July 6, 1991, 10; Pete Hamill, "How to Save the Homeless - And Ourselves," New York, September 20, 1993, 10; Sara Rimer, "Doors Closing as Mood on the Homeless Sours," New York Times, November 19, 1989, 1 .

${ }^{10}$ For an overview of this literature, see Barrett A. Lee, Kimberly A. Tyler, and James D. Wright, "The New Homelessness Revisited," Annual Review of Sociology 36 (2010), 511.

${ }^{11}$ As Themis Chronopoulos has demonstrated, the "broken windows" policing that characterized quality of life measures in New York City was just the most recent iteration of a much longer history of public policy aimed at regulating urban disorder.

Chronopoulos identifies the rise of homelessness in New York City as an outcome of neoliberal economic policies, and the policing of the homeless as a result of the turn to neoconservative social policies regarding the regulation of public space. Themis Chronopoulos, Spatial Regulation in New York City: From Urban Renewal to Zero Tolerance (New York: Routledge, 2011), 2.

${ }^{12}$ Ruth Rosenberg to Mayor Edward I. Koch, September 9, 1981, Mayor Edward I. Koch Collection, “Correspondences, 1981," Box 4, Folder 15, MACNY.

${ }^{13}$ For more on New York City in the 1970s, including the governmental policy of "planned shrinkage" and other aspects of urban disinvestment, see Joe Flood, The Fires: How A Computer Formula, Big Ideas, and the Best of Intentions Burned Down New York City - and Determined the Future of Cities (New York: Riverhead, 2010); Joshua B.

Freeman, Working-Class New York: Life and Labor Since World War II (New York: The New Press, 2001), 256-287; William K. Tabb, The Long Default: New York City and the Urban Fiscal Crisis (New York: Monthly Review Press, 1982). Themis Chronopoulos provides an important counter-narrative to the conventional story of urban disinvestment by arguing that the John V. Lindsay mayoral administration (1968-1973) actually attempted to improve garbage collection services after years of dysfunction: Themis Chronopoulos, "The Lindsay Administration and the Sanitation Crisis of New York City, 1966-1973,” Journal of Urban History 40 (November 2014), 1138-1154.

${ }^{14}$ J. Zamgba Browne and Jerold Bishop, "Koch won't move homeless shelter," New York Amsterdam News, December 4, 1982, 1; Sharon Lord Gaber, "From NIMBY to Fair Share: The Development of New York City's Municipal Shelter Siting Policies, 19801990," Urban Geography 17:4 (1996), 301.

15 Joel Blau, The Visible Poor: Homelessness in the United States (New York: Oxford University Press, 1992), 146; Alex S. Vitale, City of Disorder: How the Quality of Life 
Campaign Transformed New York City Politics (New York: New York University Press, 2008), 145-146.

${ }^{16}$ Postcard to Mayor Koch, undated (1981), Mayor Edward I. Koch Collection, General Correspondences, Box 3, Folder 10, MACNY.

${ }^{17}$ Ella Howard's recent book focuses on the changing geography of homelessness in New York City primarily in the first half of the twentieth century; in a final section on the latetwentieth century, however, she briefly notes that in the 1980s anti-homeless facility protests were "the common reply" of New York City neighborhood residents. Ella Howard, Homeless: Poverty and Place in Urban America (Philadelphia: University of Pennsylvania Press, 2013), 208. Other histories of homelessness include Todd DePastino, Citizen Hobo: How A Century of Homelessness Changed America (University of Chicago Press, 2003); and Kusmer, Down and Out, on the Road.

${ }^{18}$ See, for instance, Barrett A. Lee, Chad R. Farrell, and Bruce G. Link, "Revisiting the Contact Hypothesis: The Case of Public Exposure to Homelessness," American Sociological Review 69:1 (February 2004), 40-63; Lois Takahashi, Homelessness, AIDS, and Stigmatization: The NIMBY Syndrome in the United States at the end the Twentieth Century (Oxford, U.K.: Clarendon Press, 1998), x-xi.

${ }^{19}$ John C. Kilburn, Stephen E. Costanza, Kelly Frailing, and Stephanie Diaz, "A Paper Tiger on Chestnut Lane: The Significance of NIMBY Battles in Decaying Communities," Urbanities 4:2 (November 2014), 3-20.

${ }^{20}$ Hopper, Reckoning with Homelessness, 239 (footnote 28); Jennifer R. Wolch and Michael J. Dear, Malign Neglect: Homelessness in an American City (San Francisco: Jossey-Bass Publishers, 1993).

21 “Inequality Among Neighborhoods," City Limits 10:7 (August-September 1985), 13. This race and class bifurcation had begun much earlier. As Jerald E. Podair notes, New York was a blue-collar town in 1945, but had become a white-collar town by 1965, and "the city's new middle class was composed primarily of whites, not blacks." Jerald E. Podair, The Strike That Changed New York: Blacks, Whites, and the Ocean HillBrownsville Crisis (New Haven, CT: Yale University Press, 2004), 9.

22 The Upper West Side was one of only a few neighborhoods that received such targeted policing of petty crimes and misdemeanors in the 1980s, and these methods were never fully successful during this time. Jonathan Soffer, Ed Koch and the Rebuilding of New York City (New York: Columbia University Press, 2010), 255-275. Some of the best evidence of the expansion of this type of policing on the Upper West Side in the 1980s can be found in the pages of the local publication the West Side Spirit. There, articles regularly reported on efforts to police the street drug trade and other public space issues, as well as on the gentrification of the neighborhood (only rarely did these two topics consciously overlap in WSS articles). For a few examples, see: Gilbert Scott, "West Side 
Crime," West Side Spirit, March 4, 1985; Christina Hoag, "What's Next For Amsterdam?" West Side Spirit, March 11, 1985; and an advertisement that ran continuously entitled, "Turn In A Pusher and Get A Reward," in which the WSS editorial board offered readers $\$ 500$ "for ever tip that leads to the arrest, and conviction of a drug dealer, anywhere on the West Side."

${ }^{23}$ Howard, Homeless: Poverty and Place in Urban America, 179-209.

24 “Inequality Among Neighborhoods," City Limits 10:7 (August-September 1985), 13. As Neil Smith has argued, Harlem was on the cusp of potential gentrification as early as the 1970s, when developers began buying buildings on the western corridor of the neighborhood that bordered Morningside Heights and the Upper West Side. However, this gentrification was piecemeal and localized at the time, and most parts of Harlem were not yet affected by these changes. Smith, The New Urban Frontier: Gentrification and the Revanchist City, 136-162.

${ }^{25}$ In the ensuing years, New York State courts would extend the mandate for shelter to also apply to homeless women and homeless families; but Callahan v. Carey applied only to homeless men, who were at the time the fastest-growing and most visible of un-housed people in New York City (as well as the population most understood as a social problem by New York residents and the municipal government). For more on the case and its repercussions for New York City's administration of shelter and homeless services, see "The Callahan Legacy: Callahan v. Carey and the Legal Right to Shelter," obtained from website of Coalition for the Homeless on September 26, 2013, $\mathrm{http}$ ://www.coalitionforthehomeless.org/pages/the-callahan-legacy-callahan-v.-careyand-the-legal-right-to-shelter; Soffer, Ed Koch and the Rebuilding of New York City, 282285.

${ }^{26}$ Deirdre Carmody, "Proposed Referral Center for Homeless Disturbs West Side Neighborhood," New York Times, May 25, 1981, B5; "Center to Help Vagrants Wins West Side Vote," New York Times, June 4, 1981, B3.

${ }^{27}$ Doug and Dana Wyles to Mayor Edward I. Koch, June 10, 1981, Mayor Edward I. Koch Collection, General Correspondences, Box 3, Folder 10, MACNY.

${ }^{28}$ Local newspapers attested to the transformation of the northern blocks of the Upper West Side from a racially diverse, lower-income area of the city to a gentrifying neighborhood drawing upscale businesses and more white, upper-income residents by the 1980s. The West Side Spirit addressed this gentrification and its implications in numerous articles during its inaugural year of publication, 1985. For examples, see: Christina Hoag with Michael Davison and Evelyn Powers, "What's Next for Amsterdam?" West Side Spirit, March 11, 1985, 4; State Senator Franz S. Leichter, "The Future of the West Side," West Side Spirit, April 8, 1985, 8. 
${ }^{29}$ For more on WSURA and the city's long history of urban renewal on the Upper West Side, see Chronopoulos, Spatial Regulation in New York City, 20-32. As Chronopoulos argues, many of the slum-like conditions in the area originated with the city's slumclearance program itself: Most households evicted by the city from the renewal area relocated mere blocks away, creating overcrowding conditions and artificially inflating rents in the area.

${ }^{30}$ Susan Baldwin, "West Side Renewal Story: The Legal Battle Is Won, The Political Battle Remains Unwaged," City Limits (December 1982), 27-29; Dick Oliver, "The Hidden Demographics of the West Side," West Side Spirit, June 17, 1985, 1. Even as late as 1980, the neighborhood was decidedly poorer than the area to its south, with household incomes averaging between $\$ 10,000$ and $\$ 20,000$, compared to the average income of $\$ 25,000$ for households in the neighborhood's southern half (roughly below $87^{\text {th }}$ Street). Harlem, which bordered the neighborhood on the north, had an average household income below $\$ 10,000$. For an analysis of the role of local and city-wide institutions in the transformation of the Upper West Side in the 1970s, see David Wilson, "Urban Revitalization on the Upper West Side of Manhattan: An Urban Managerialist Assessment," Economic Geography 63: 1 (January 1987), 35-47.

${ }^{31}$ John Douw, "Poor People: The New Environmental Hazard," City Limits (February 1979), 12-13. In 1981, the city finally won the right to build the low-income housing it had planned, but urban renewal had, by then, declined as a policy, and observers noted the increasing unlikeliness that the city would follow through with its long-deferred plans. Baldwin, "West Side Renewal Story," 27-29.

32 The West Side Community Task Force on Single Room Occupancy Housing, "Report \#1" (June 1978), 2, 6.

${ }^{33}$ The history of the siting of "undesirable" facilities - including factories, waste treatment facilities, and harmful chemical storage facilities - in underprivileged neighborhoods and communities of color is long and increasingly well documented. The environmental justice movement arose to address such issues in the 1970s. To connect the placement of low-income housing to more traditionally-understood "environmental" hazards is both apt and disturbing: apt because a similar process of placing "undesirable" facilities in disempowered communities is indeed at work, and disturbing because the implication — often explicitly or near-explicitly stated - is that poor people and others in need of social services are themselves environmental hazards. For works on environmental racism, see: Melissa Checker, Polluted Promises: Environmental Racism and the Search for Justice in a Southern Town (New York: NYU Press, 2005); Andrew Hurley, Environmental Inequalities: Class, Race, and Industrial Pollution in Gary, Indiana, 1945-1980 (Chapel Hill: The University of North Carolina Press, 1995); Julie Sze, Noxious New York: The Racial Politics of Urban Health and Environmental Justice (Cambridge, MA: The MIT Press, 2006); Dorceta Taylor, Toxic Communities: Environmental Racism, Industrial Pollution, and Residential Mobility (New York: NYU Press, 2014). 
${ }^{34}$ Francis A. Lackner to Mayor Edward I. Koch, October 8, 1981, Mayor Edward I. Koch Collection, General Correspondences, Box 3, Folder 10, MACNY.

${ }^{35}$ Minnie G. Horowitz to Mayor Edward I. Koch, June 13, 1981, Mayor Edward I. Koch Collection, General Correspondences, Box 3, Folder 10, MACNY; Ellyn Berman to Mayor Edward I. Koch, October 5, 1981, Mayor Edward I. Koch Collection, General Correspondences, Box 3, Folder 10, MACNY.

${ }^{36}$ Ms. Roberta Jeanne Nicolella to Mayor Edward I. Koch, September 4, 1981, Mayor Edward I. Koch Collection, "Correspondences, 1981," Box 4, Folder 15, MACNY; Nina Collins to Mayor Edward I. Koch, July 19, 1981, Mayor Edward I. Koch Collection, "Correspondences, 1981," Box 4, Folder 15, MACNY.

${ }^{37}$ Susan Levin to Mayor Koch, August 11, 1981, Mayor Edward I. Koch Collection, General Correspondences, Box 3, Folder 10, MACNY.

${ }^{38}$ Doug and Dana Wyles to Mayor Koch, June 10, 1981, Mayor Edward I. Koch Collection, General Correspondences, Box 3, Folder 10, MACNY.

${ }^{39}$ The term "derelict," though its usage was fading by the early 1980s, captured well the social position un-housed people occupied. ${ }^{39}$ The term literally means "abandoned" or "neglected," implying that derelicts were passive victims of a society that deserted them. But in the context of the conflict over the Assessment Center and other not-in-my-backyard struggles, "derelict" was also an accusation leveled against those who held its title. City residents feared for their safety and social comfort; they worried that derelicts' mental and bodily disorder would, uncontained by physical boundaries, spill into their neighborhoods and onto their own bodies. Derelicts had not only been abandoned by society - they had also abandoned themselves, or at least the social norms that governed proper behavior and bodily comportment. They themselves, the discourse implied, were the authors of their own dereliction. Hopper, Reckoning With Homelessness, 7.

${ }^{40}$ Susan Levin to Mayor Koch, August 11, 1981, Mayor Edward I. Koch Collection, General Correspondences, Box 3, Folder 10, MACNY; (Mrs. Jesse) Edith Rosenstock to Mayor Koch, June 14, 1981, Mayor Edward I. Koch Collection, General Correspondences, Box 3, Folder 10, MACNY; Doug and Dana Wyles to Mayor Koch, June 10, 1981, Mayor Edward I. Koch Collection, General Correspondences, Box 3, Folder 10, MACNY; Resident (no name given) to Mayor Koch, October 5, 1981, Mayor Edward I. Koch Collection, General Correspondences, Box 3, Folder 10, MACNY.

${ }^{41}$ As Khalil Gibran Muhammad notes, "Violent crime rates in the nation's biggest cities are generally understood as a reflection of the presence and behavior of the black men, women, and children who live there." Mark Anthony Neal argues that black men are seldom "legible" as anything other than criminals in the popular consciousness, and that this construction is used to justify the staggering rates at which black men are 
incarcerated and subjected to other forms of legal and extralegal violence in the United States. Michelle Alexander examines the legal and citizenship ramifications of this racialized system of criminalization in The New Jim Crow. Michelle Alexander, The New Jim Crow: Mass Incarceration in the Age of Colorblindness (New York City: The New Press, 2010); Khalil Gibran Muhammad, The Condemnation of Blackness: Race, Crime, and the Making of Modern Urban America (Cambridge, MA: Harvard University Press, 2011), 1; Mark Anthony Neal, Looking for Leroy: Illegible Black Masculinities (New York City: New York University Press, 2013), 4-6.

${ }^{42}$ Carmody, "Proposed Referral Center for Homeless Disturbs West Side Neighborhood," B5.

${ }^{43}$ Vivian Hagl to Mayor Koch, undated, Mayor Edward I. Koch Collection, General Correspondences, Box 3, Folder 10, MACNY; N. Figuero to Mayor Koch (undated), Mayor Edward I. Koch Collection, General Correspondences, Box 3, Folder 10, MACNY.

${ }^{44}$ Mrs. M.G. Horowitz to Mayor Koch, June 13, 1981, Mayor Edward I. Koch Collection, General Correspondences, Box 3, Folder 10, MACNY.

45 (Mrs. Jesse) Edith Rosenstock to Mayor Koch, June 14, 1981, Mayor Edward I. Koch Collection, General Correspondences, Box 3, Folder 10, MACNY.

${ }^{46}$ Danielle McCafferty to Mayor Koch, undated, Mayor Edward I. Koch Collection, General Correspondences, Box 3, Folder 10, MACNY.

${ }^{47}$ Susan Levin to Mayor Koch, August 11, 1981, Mayor Edward I. Koch Collection, General Correspondences, Box 3, Folder 10, MACNY; Minnie G. Horowitz to Mayor Koch, June 13, 1981, Mayor Edward I. Koch Collection, General Correspondences, Box 3 , Folder 10, MACNY.

${ }^{48}$ Koch's frustration was not aimed solely at those protesting the placement of homeless services in their neighborhoods: At the same moment, Chinatown residents were decrying the expansion of a city jail and Brooklynites marched against a planned waste treatment facility.

49 Angela Jones, “Angry East New Yorkers Want 400 Derelicts Out,” New York Amsterdam News, November 7, 1981, 9. This fact was also confirmed when State Senator Major Owens visited the site on October $21^{\text {st }}$ and found that "extensive preparations had been made and the school had been kept in excellent condition for this 'sudden emergency.", "Owens Attacks Quotas," New York Amsterdam News, November 7, 1981, 33.

${ }^{50}$ Nathan Leventhal interviewed by Sharon Zane, August 12-November 24, 1992 , Edward I. Koch Oral History Collection, Columbia University. While many politicians 
and housing advocates did indeed describe rising homelessness as an "emergency," Leventhal's use of the term obscures the city's own shortcomings in planning for the rising amount of need for shelter that, by 1981, was well established. In its 1982 report, "Cruel Brinkmanship," the Coalition for the Homeless noted that the city had repeatedly ignored court orders to submit plans to expand the municipal shelter systems. Further, most of the shelters it did open - including the P.S. 63 shelter - violated the terms dictated by Callahan v. Carey by exceeding building capacity and not providing adequate toilets or showers for shelter users. Coalition for the Homeless, "Cruel Brinkmanship: Planning for the Homeless - 1983" (August 16, 1982).

${ }^{51}$ Angela Jones, “Angry East New Yorkers Want 400 Derelicts Out,” New York Amsterdam News, November 7, 1981, 9.

${ }^{52}$ Walther Thabit, How East New York Became A Ghetto (New York City: New York University Press, 2005), 169. Scholarly works on residential segregation, redlining, and urban decline are numerous. Two of the most prominent examples are: Kenneth Jackson, Crabgrass Frontier: The Suburbanization of the United States (New York: Oxford University Press, 1987), 190-230; Thomas J. Sugrue, The Origins of the Urban Crisis: Race and Inequality in Postwar Detroit (Princeton, N.J.: Princeton University Press, 1996). For this history as it relates to other areas of Brooklyn, see Wendell E. Pritchett, Brownsville, Brooklyn: Blacks, Jews, and the Changing Face of the Ghetto (Chicago: The University of Chicago Press, 2003); Craig Steven Wilder, A Covenant with Color: Race and Social Power in Brooklyn (New York City: Columbia University Press, 2001), 175-218.

${ }^{53}$ Frank Dexter Brown, "Homeless Shelter Sparks Fear, Spite," New York Amsterdam News, January 2, 1982, 1.

${ }^{54}$ Angela Jones, “Angry East New Yorkers Want 400 Derelicts Out," New York Amsterdam News, November 7, 1981, 9.

55 The definitive work on Harlem in the twentieth century is Gilbert Osofsky, Harlem: The Making of a Ghetto, $2^{\text {nd }}$ edition (Chicago: Ivan R. Dee, 1996). On the history of citizens' activism surrounding housing and racial discrimination in Harlem, see Mandi Isaacs Jackson, "Harlem's Rent Strike and Rat War: Representation, Housing Access, and Tenant Resistance in New York, 1958-1964," American Studies 47:1 (Spring 2006), 53-79. While Harlem undoubtedly experienced disinvestment throughout the twentieth century, Neil Smith has argued that its proximity to Midtown Manhattan led the Koch administration to consider it ripe for gentrification in the 1980s; some areas along the western corridor of the neighborhood, in fact, had already experienced an upsurge in real estate prices as early as the 1970s. Neil Smith, The New Urban Frontier: Gentrification and the Revanchist City (New York: Routledge, 1996), 136-162.

56 J. Zamgba Brown, "Koch Won't Move Homeless Shelter," New York Amsterdam News, December 4, 1982, 1. 
${ }^{57}$ Thea Breite, “Harlem to Koch - 'No Homeless Here'," Uptown, December 8, 1982, 1.

58 “Owens Attacks Quotas,” New York Amsterdam News, November 7, 1981, 33.

${ }^{59}$ J. Zamgba Browne and Gerald Bishop, "Koch Won't Move Homeless Shelter," New York Amsterdam News, December 4, 1982, 1.

${ }^{60}$ Frank Dexter Brown, "Homeless Shelter Sparks Fear, Spite," New York Amsterdam News, January 2, 1982, 1.

${ }^{61}$ Community Residents of Harlem, "Harlem Community in Danger: Men's Shelter Planned for Sydenham," November 15, 1982. Mayor Edward I. Koch Collection, Departmental Correspondences, Box 90, Folder 11, MACNY.

62 Jinaki Bryant, "Hysteria Sets In,” New York Amsterdam News, July 14, 1979.

${ }^{63}$ Mayor Edward I. Koch to Clark Whelton, December 15, 1982, Mayor Edward I. KochCollection, Departmental Correspondences, Box 90, Folder 11, MACNY.

64 “The Homeless in Harlem,” New York Amsterdam News, November 27, 1987, 14.

65 Julie Duvall, "Choices Facing Harlem," New York Amsterdam News, December 18, 1982, 52; Mrs. Julian Jordan, "Homeless Issue is a Challenge," New York Amsterdam News, December 18, 1982, 52.

${ }^{66}$ J. Zamgba Browne and Jerold Bishop, "Koch Won't Move Homeless Shelter," New York Amsterdam News, December 4, 1982, 1. For further documentary evidence of this phenomenon, see Gaber, "From NIMBY to Fair Share," 301, 303, and 305.

${ }^{67}$ Thea Breite, “Harlem to Koch - 'No Homeless Here'," Uptown, December 8, 1982, 1.

${ }^{68}$ Sheila Rule, "Neighbors Join to Assist Shelter on the East Side," New York Times, February 19, 1983, 27.

${ }^{69}$ Rule, "Neighbors Join to Assist Shelter on the East Side," 27.

${ }^{70}$ Gaber, "From NIMBY to Fair Share," 302-304.

71 “Editorial: NIMBY’s Smoke Screen,” City Limits (November 1987), 2.

72 Mary Papenfuss, "Shelter Wars," City Limits (December 1986), 8. 
${ }^{73}$ For one example, see William H. Grinker to Stanley Brezenoff, "Memorandum: Panhandling," August 17, 1988, Mayor Edward I. Koch Collection, Departmental Correspondences, Box 196, Folder 6, MACNY. 


\title{
"The Guardian Angels: Law and Order and Citizen Policing in New York City"
}

\author{
Reiko Hillyer
}

\begin{abstract}
:
This article explores the rise of the Guardian Angels, a community patrol organization founded in 1979 in New York City by Curtis Sliwa and composed mainly of black and Latino youths. The group emerged in an era of economic restructuring coupled with a rising fear of crime. The Guardian Angels merit attention because of their peculiar relationship to the rise of law and order politics. They demonstrate that the fear of crime was neither the monopoly of the white middle class nor merely a construction of politicians. Black and Latino Guardian Angels were agents of community crime control who drew on existing customs of self-determination and distrust of the police. Ultimately, however, the activities and the rhetoric of the Guardian Angels contributed to the rise of a conservative discourse that justified the strengthening of the police state, anxiety about crime, and the gentrification of neighborhoods.
\end{abstract}

Keywords: New York City, community policing, fiscal crisis, law and order, broken windows theory, gentrification

\section{Acknowledgements:}

I wish to thank Jonathan Soffer and Themis Chronopoulos for their helpful comments. I am also grateful to Mason Williams, Kim Phillips-Fein, Elliott Young, Maureen Reed, Will Pritchard, Mo Healy, and members of the History Department at Lewis and Clark College for their feedback on earlier iterations of this article. I would also like to thank Micol Siegel, David Menschel, Elizabeth Blackmar, and Vesla M. Weaver for their support and insight.

\section{Author Biography:}

Reiko Hillyer is an assistant professor of history at Lewis and Clark College in Portland, Oregon. Her first book, Designing Dixie: Tourism, Memory, and Urban Space in the New South, concerns the uses of public memory and tourism in fostering sectional reconciliation and economic development in the American South in the decades following the Civil War. 
In February of 1979, a group of black and Latino teenagers boarded the number 4 IRT train in the Bronx, known as "The Muggers' Express." Wearing jungle fatigue pants, sunglasses, combat boots, and red-berets festooned with raccoon tails, the group spread out throughout a train car, unsmiling and alert. Though one journalist later remarked that the crew resembled "Nicaraguan guerillas," they intended to keep peace: to patrol the subway and deter crime with their intimidating presence and their willingness to intervene. ${ }^{1}$ That very evening, some members of the patrol stopped a mugging at $167^{\text {th }}$ Street in the Bronx; while restraining the mugger, they asked the train's conductor to alert the transit police. ${ }^{2}$ Founded by Curtis Sliwa, a 26-year-old of Polish and Italian descent, the squad, which would soon call itself the Guardian Angels, eventually took its patrols above ground to parts of the city perceived to be overtaken by criminals.

The Guardian Angels, who, according to Police Magazine, looked "like a cross between a Special Forces military squad and a street gang," aroused spirited controversy among New Yorkers; they were perceived by some journalists as "ghetto boy scouts" coming to the rescue of beleaguered citizens and by others as vigilantes. ${ }^{3}$ The group captured the public's frustration with the disorder of the city and revived a populist language of civic morality and personal responsibility. ${ }^{4}$ They were particularly welcome on the graffiti-covered subway, described by Jere Hester, a writer for the Daily News, as a "festering Petri dish breeding violent young punks" and a synecdoche for the condition of the city at large. ${ }^{5}$ Studies showed that crime was not worse on the trains than above ground, but one commuters' advocacy group, The Straphangers' Campaign, argued that "many riders see and experience threatening shouts, menacing gestures, irrational and unmannerly behavior." "Subway riders believed that police, understaffed and hamstrung by liberal court decisions, weren't doing enough to control social disorder. One New Yorker wrote to the New York Times, "It is time to realize that our police force is losing the battle against crime, and the citizenry must take a more active role in halting its spread."7 While Lieutenant Governor Mario Cuomo considered it "a dramatic embarrassment that riders in our subways should pray for the appearance of a band of young minority people in berets and T-shirts," in the wake of transit police cutbacks, the Angels had answered riders' prayers. $^{8}$

Responding to exasperation with "human garbage" preying on passengers while cops "were just hanging around at the doughnut stands," Sliwa's Guardian Angels began eight-member patrols on the 230-mile subway system seven days and nights a week, fanning through cars and using elaborate signals to summon help. ${ }^{9}$ Unarmed but trained in martial arts, with code names such as "Spider" and "Ace," these regular passengers considered the subway their back yard. ${ }^{10}$ By 1981, the group grew to approximately 700 volunteers, about eighty-five percent of whom were black or Latino from poor neighborhoods. ${ }^{11}$

The Guardian Angels emerged in New York City in an era of economic restructuring coupled with a rising fear of crime. In 1975, New York City was facing bankruptcy. President Ford's refusal to bail out the city reflected the nation's disgust with urban decay and with the liberal policies that supposedly abetted it. Upon his election in 1978, Mayor Edward Koch, who ran for office as a law-and-order candidate arguing for the reinstatement of the death penalty, promoted gentrification and privatizing public space to renew the city as a node for a global economy increasingly based on information and finance. He offered tax breaks to convert former flophouses into luxury apartments 
and created a system of tax incentives to encourage the construction of office buildings. ${ }^{12}$ He also initiated the redevelopment of Times Square in an effort to attract tourists and corporate headquarters. ${ }^{13}$

In this context, the Guardian Angels merit attention because of their peculiar relationship to the rise of law and order politics. Most scholars of the period agree that "law and order" - which started out with the "war on crime" and then became "the war on drugs"- was a conservative reaction against the rights revolutions of the $60 \mathrm{~s}$ and the expansion of the welfare state during the Great Society; further, scholars have demonstrated that law and order policies disproportionately targeted young men of color. ${ }^{14}$ By the 1980s, in New York City, the desire to "civilize" the city encouraged "broken windows" policing, a theory of social control that held that allowing minor signs of social and physical disorder to go unaddressed led to more serious crime problems. ${ }^{15}$ The theory's popularity with city leaders, in turn, fostered gentrification and its accompanying removal and criminalization of so-called undesirables - the homeless and youth of color - so that the city could attract middle-class consumers and corporate investment. ${ }^{16}$ When Rudolph Giuliani was elected mayor in 1993, he underwrote his attack on liberalism and his focus on crime control with a "quality of life" and "zero tolerance" strategy, according to which the solution to social dislocation was to get tough on the minor incivilities and petty crimes that seemed to dominate everyday life. To the Giuliani Administration, the cause of urban disorder and decline was the misguidedness of liberalism and its spawn, deviant youth of color. The solution was aggressive policing. $^{17}$

The Guardian Angels complicate that narrative, offering a nuanced perspective on how law and order played out on a local level and challenging a neat binary of the political left and right. On the one hand, the Angels were largely black and Latino youths, frequently targeted by the police; on the other hand, they advanced the notion that the city needed tougher policing. If, as Guardian Angel Lisa Evers proudly noted, Guardian Angels' supporters ranged from the tenants of public housing projects to members of the John Birch Society, the Angels suggest that scholars should pay closer attention to how poor communities of color responded to crime as commitments to public services shrank.

As this article will elaborate, fear of crime was neither the monopoly of the white middle class nor merely a construction of politicians. The Guardian Angels reveal that the concerns and strategies of communities of color-indeed, more likely to be the victims of crime - often overlapped with those of conservatives. ${ }^{18}$ Their support for crime prevention, however, did not emerge from a "revanchist antiurbanism," to borrow from Neil Smith, but from their experience of residing in communities underprotected by the police. ${ }^{19}$ Scholars such as Michael Javen Fortner and James Forman, Jr. have demonstrated that communities of color did call for tougher anti-crime policies, but these scholars do not capture the range of strategies advanced by such communities. Neither passive victims of tough-on-crime policies nor a conservative "black silent majority," black and Latino Guardian Angels were agents of community crime control who drew on existing customs of self-determination and distrust of the police. ${ }^{20}$ In calling upon selfreliance within poor communities of color, they promoted a kind of "third way" of managing public space and the rise in crime as an alternative to, and sometimes in opposition to, the police. As Fritz Umbach has argued of tenant activists in public housing, identifying how poor people of color promoted law and order "is not the same 
thing as holding them responsible for its current form"; rather, this work illustrates how those very people most demonized by conservatives also mobilized against crime. ${ }^{21}$

Significantly, The Guardian Angels came to the scene in the context of fiscal austerity, when municipal cutbacks shrank the police department by the thousands, making it temporarily impossible to initiate the aggressive policing that would later be characteristic of the punitive turn with which we are now familiar. ${ }^{22}$ The origins and meaning of their ascent contributes to what historian Kim Phillips-Fein has called a "social history of austerity." ${ }^{, 3}$ Between the conservative backlash of the 1960s and 1970s and the expansion of "quality of life" policing in the 1980s and 1990s, the Guardian Angels created their own solution to the city's crime problem, revealing what "law and order" looked like to non-elites of color in the absence of a strong state. Ultimately, the activities and the rhetoric of the Guardian Angels contributed to the rise of a conservative discourse that justified the strengthening of the police state, anxiety about crime, and the gentrification of neighborhoods. ${ }^{24}$

\section{"Ghetto Boy Scouts": Forming the Guardian Angels}

Guardian Angels emerged at a moment in which their desire for self-reliance and protection coincided with a larger interest in seeking ways to feel safer in New York City. The Angels' success in deterring crime was difficult to measure and covered in heroic press stories frequently dismissed as hype, but sociological studies concluded that citizens were generally comforted by their "perceived assurance that the Angels will seek and maintain a sense of order." 25 Sixty-one percent of subway passengers interviewed in the mid-1980s reported that the Angels made them less fearful. ${ }^{26}$ One journalist reported that when Angels entered a subway car, passengers who had been eyeing each other warily broke into hearty applause. ${ }^{27}$ Angels co-founder Arnaldo Salinas recalled that this kind of accolade was "better than an orgasm." ${ }^{28}$ One Manhattan resident wrote to the New York Post, "The Guardian Angels are very much appreciated by the commuters who must take the subway every day." Another New Yorker declared, "Bravo to the Guardian Angels! I am truly impressed with their courage and initiative. . . . They do have halos!"29 One study noted that "the Angels are composed primarily of minority, inner city youth who are often perceived as the very agents of crime," but this observation is only striking if one assumes that minority youth were not disturbed by crime. ${ }^{30}$ The fact that those most reassured by the presence of the Angels were adult black men, especially those commuters who lived in the Bronx and rode the subways in the evening, shows that anxiety about crime was shared by New Yorkers across race and class. ${ }^{31}$

Recurring media coverage about the Guardian Angels reflected ambivalence as well as appreciation for their mission; similarly, leader Curtis Sliwa was alternately vilified and hailed by the city's press (Figure 1). Ubiquitous in the tabloids and on talk shows, profiles of Sliwa illustrate his facility at shifting from street dialect to media jargon. Stories that praised Sliwa often focused on his appealing background. Described by a journalist as "Jimmy Cagney with... a heap of P. T. Barnum," Sliwa grew up in Canarsie, Brooklyn, the son of a merchant seaman and a dental assistant. ${ }^{32}$ By his own account, he was a good Samaritan from an early age: at five years old he scolded a woman for opening a candy bar before paying for it; as a teenager, he collected newspapers and cans and called an industrial supplier to pick up the refuse, eventually earning him an award from Governor Nelson Rockefeller for exemplary volunteer 
service. ${ }^{33}$ His greatest influence, Sliwa noted, was his immigrant Italian grandfather. "He instilled in me my feeling for volunteer service," recalled Sliwa. "He gave me a lot of my value system. He was seventy years old and bent over, and he'd still sweep the sidewalk in front of the house every day.... He taught me two things. 'Don't be afraid of hard work' and 'Don't wait for anybody else to do it. Get off your butt and do it yourself.",34

This charisma drew marginalized teenagers to Sliwa's flock (Figure 2). He served as a father figure who saw potential in the people most demonized by those calling for a crackdown on urban disorder. "Maybe they've never been in a house, never seen an adult male who didn't hurt someone else," Sliwa reflected of his charges. "They have no concept of something positive.... They're fine young people, but they need some direction. And we give them that. We show them it's cool to be good, it's cool to be positive. ${ }^{, 35}$ Sliwa described how important it was for the teen Angels to win praise from subway riders; many of them, he said, "had never been complimented for anything in their lives. ${ }^{, 36}$ One commented that the New York Guardian Angels offered such teens "some of the first real discipline and community encouragement they have ever received." ${ }^{37}$ A sociological study remarking on the importance of the Angels as "role models" noted that the organization "combines the macho image with an orientation that supports the value of helping others. In essence, Sliwa makes it 'cool' to be an Angel.",38

The comments of Guardian Angels recruits further suggest that, "the Angels make it cool to care.",39 One former Angel reflected that joining the organization "was something exciting to do that wasn't trouble-making," blending a rebellious virility with "an element of the boy scout." ${ }^{40}$ Another explained the thrill of going on subway patrols: "The idea is romantic, like Batman and Robin. We go to the mugger's delight, the most dangerous places. One dude called me a toy-cop and told me to go sing the national anthem. But I know we're doing a good thing., ${ }^{41}$ Some Angels believed that the organization saved them from the strong lure of gangs, which, according to Sliwa, offered a young men a perverse but logical immediate gratification; "You're gonna end up in jail or dead," Sliwa hypothesized, "so just go for it, pleasurize [sic] yourself.... This ride is gonna be over soon one way or the other." "42 Of Orlando Ortiz, a 16-year-old from Spanish Harlem, a journalist commented, "The Angels, he says, keep him off the streets. 'And if I was in the streets,' says Ortiz, 'I'd be doin' bad things.",43 "Rocky," 21, said that he was in a gang in Queens before joining the Angels. He left home when he was 15 and, "wasn't doing so good," involved in petty theft and graffiti, and "I wasn't goin' nowhere.... Then a good friend of mine starts talking to me about the Guardian Angels... He knows I always had a basic goodness."

Sliwa saw the hopelessness and despair of Bronx youth who were "stuck — people with the wherewithal would pack their bags and leave for the suburbs" - and rallied them with a sense of community obligation. "These are your moms, your brothers, your sisters, your relatives who are getting assaulted and robbed and brutalized, gangs are taking over your neighborhood." "45 Such words resonated with Karl "K. K." Wilds, 19, who wanted to become a kind of solo avenger after his mother was mugged twice on the $\mathrm{F}$ train, but felt reluctant to intervene in such muggings alone ${ }^{46}$ Sliwa pointed out to youths like him, "You can't do anything by yourself. But in a group, you have the ability to turn things around." ${ }^{, 47}$ As black journalist Clinton Cox bemoaned in 1981, "Our children have always been the victims of violence, whether it was the violence of the murderer who ends their physical lives or the violence of poverty and closed doors that ends their hopes and 
dreams. $" 48$ In this void of nihilism and neglect, Curtis Sliwa's Guardian Angels promised a productive alternative.

\section{"Something of a Pickle": The Guardian Angels, Black Communities, and The Police}

The frustration that fueled Sliwa's recruitment of young Guardian Angels would eventually culminate in a growth in the police state. The roots of this movement, however, can be best understood as part of an ongoing fraught relationship between the police and the communities of color from with the Guardian Angels drew recruits. The appeal of the Guardian Angels reflected a larger skepticism of traditional sources of authority and government among poor people of color who were angry about abusive policing, disappointed in liberal promises, frustrated by cutbacks to public services, and wary of the rightward trend of city and national government.

Communities of color found themselves at once harassed by the police and inadequately protected from crime. Recent scholars have identified black support for more punitive crime policies, such as the draconian Rockefeller Drug Laws. ${ }^{49}$ In the 1960s, for example, Reverend Oberia D. Dempsey of Harlem proposed, "Take the junkies off the streets and put 'em in camps," and in 1970s and 80s, black spokespeople insisted that "the millions of striving, law-abiding Negroes... are endangered" by "rampaging kids." Some white conservatives eagerly pointed out that "one of the best kept secrets in this country is that black people are more fed up with crime than white people are. ${ }^{, 51}$ But the grass-roots response to and interpretation of crime in poor neighborhoods was not monolithic. " "Too often," political scientist Vesla M. Weaver and Charles Decker have written, "critical differences between local black anti-crime advocates and white 'law and order' elites get flattened." 53 Black New Yorkers did not simply propose the same solutions as white conservatives. Black commentators warned against "law and order" as a euphemism for racism, reminding black citizens that white conservatives did not care about crime in Harlem. ${ }^{54}$ African-American attorney and civil rights leader Louis Clayton Jones observed that crime in black communities put AfricanAmerican New Yorkers "in something of a pickle"; on the one hand, he argued, "the African crime rate will...increase exponentially as the food, clothing and shelter of former welfare recipients cease to be available," while Mayor Ed Koch continued with "inane rantings about the "savages' every time a policeman is shot." The result of this impending "Fascist state" would be that "the mob will have concluded that the extermination of the 'black cancer' is indeed the patriotic duty of every God-fearing European in America."

The black community's view of the police as an extension of an oppressive white establishment, articulated most starkly in the platform of the Black Panther Party, was one shared widely by black urban dwellers. Sociologist Robert Blauner, in a 1972 essay entitled "Racial Oppression in America," expressed a common viewpoint when observing that police in urban ghettos advanced internal colonialism: "The lay agents in the power equation, they do the dirty work for the larger system by restricting the striking back of the black rebels to skirmishes inside the ghetto, thus deflecting energies and attacks from the communities and institutions of the larger power structure."56 This interpretation did not die with the Black Panthers; a 1985 editorial in the Amsterdam News referred to the police as a "hostile army," and "while we abhor violence and lawlessness in any form... something...is happening in our city that indicates that there is a wanton disregard for 
life, especially Black life, emanating from the criminal justice system in general and the police department in particular." The editorial continued, "We are, in fact, an armed camp."

Black New Yorkers were outraged about crime and the police's ineffectiveness in their communities. ${ }^{58}$ Harlem activist Barry Simpson pointed out that "Black people are far more likely than whites to be victims of violent crimes" and argued that "we have been systematically denied access to the institutions of economic, political, and social power." ${ }^{59}$ Poor and working-class neighborhoods bore the majority of police budget cuts in an era of putatively "city-wide austerity. ${ }^{\circ 60}$ In short, black people distrusted the police because they both failed to protect all citizens and represented a hostile force. ${ }^{61}$ Simpson emphasized that his approach did not call for "stiffer penalties and sentences, building more prisons and sometimes even the death penalty for young offenders." Gesturing toward the value of grass-roots groups such as the Guardian Angels, he pointed instead to "the important role that youth must play in this battle." ${ }^{2}$ African American criminologist George Napper posited that "poor housing, poor education, unemployment and poverty ought themselves to be viewed as crimes," and that instead of "waiting for others," the black community should get involved in addressing crime. ${ }^{63}$ As one former Guardian Angel explained, 'bad neighborhoods didn't support crime, they just didn't trust the police." 64

Lacking faith in police, and faced with a conservative ideology according to which in the words of former Harlem State Representative Carl McCall, "prison [is] the promise for those too impatient to await the hoped-for trickle-down benefits of Reaganomics," poor communities of color developed self-help mechanisms of promoting safety. ${ }^{65}$ Beginning in the 1960 s and 1970 s, community patrols became the most prevalent of these mechanisms. ${ }^{66}$ For example, the Vera Institute of Justice organized, in 1968, a community patrol made up of unarmed Harlemites, dressed in tan jackets trimmed with suede, who escorted people to their destinations and collected garbage. ${ }^{67}$ Tenants Leagues in Harlem welcomed youth patrols inside public housing because they felt that the housing police were insensitive and prone to hassle the residents. A 23-yearold resident of public housing explained, "These white cops come in and they can't counsel - that's the thing about having our police live in the community. If he is an alien and a total stranger, his attitude is 'Niggers is raising trouble and I got to stop it.' That's a negative attitude." ${ }^{, 68}$ In 1976, the Community Action for Safer Harlem (CASH), led by activist and former Malcolm X bodyguard Reverend Charles Kenyatta, aimed to thwart drug trafficking in Harlem. ${ }^{69}$ In 1977, youth gangs developed projects such as escorting elderly citizens and renovating abandoned houses. ${ }^{70}$ By 1981 , approximately 13,000 public housing tenants throughout New York City had formed watch groups in 764 buildings. ${ }^{71}$ These efforts at community crime control were expressions of selfdetermination in the face of police services that were negligent at best and abusive at worst. $^{72}$ "It is only by concerned neighbors watching out for neighbors and their children," a writer for the Amsterdam News declared, "that we African Americans can reduce and possibly end crime in our communities." "73 The Guardian Angels fell into this pattern of community-based self-help, rather than "export the problem out to somebody else," but were more visible because of their outspoken leader and their subway presence. $^{74}$ 
The Guardian Angels' grass-roots arm of crime control emerged within and continued this tense relationship with the police. The New York Times reported on how, on the one hand, police felt "antagonistic toward groups that appear to symbolize official failure to stop crime." On the other hand, the Times continued, "the Angels display little sensitivity" towards police sentiment. "Their leader, Curtis Sliwa, is often arrogant and hesitates to respond to wholly legitimate requests for information about Angel operations and the backgrounds of its members." 75 The police were insulted that the Angels openly suggested that the crime in the city was the result of the police not doing their jobs, and they disparaged the Angels' lack of training and rough backgrounds. The police and Mayor Koch, more so than the general public, referred to them as vigilantes and paramilitaries. ${ }^{76}$ In a speech to graduating cops, the Police Commissioner Benjamin Ward accused the Angels of traveling around like a "wolf-pack" and compared them to a lynch mob. ${ }^{77}$ Sliwa retorted, "the citizens of New York want the crack epidemic and violence dealt with by cops. But if the cops won't do it, they'll accept people in pink shower caps, cowboy hats-or red berets." ${ }^{, 78}$ The Angels routinely got into scuffles with the police and were subject to police harassment. ${ }^{79}$ Sliwa contended, "It got to the point that if an Angel was chasing a mugger, there were probably four transit cops chasing the Angel." ${ }^{80}$ Sliwa claimed that he himself was arrested seventy-six times by police "who were clearly just looking to harass me." 81

Sliwa framed his conflicts with police in populist language, accusing skeptical city officials of losing touch with most New Yorkers. City elites were tone-deaf to the public's support of the Angels, Sliwa argued, because "Koch and [Police Commissioner] Ward spend more time in the Hamptons than they do in Hollis, Harlem, and Hunt's Point." 82 Sliwa boasted that Guardian Angels were "not in air-conditioned squad cars, not at the snack bar, not at the restaurant on their third or fourth break on an eight-hour shift — but out there in the streets - where the action is." ${ }^{83}$ Echoing ghetto residents" complaints, Sliwa emphasized that his volunteers were from the communities they patrolled, unlike the police, whom he referred to as "mercenaries." When Sliwa accused three men representing themselves as police officers of abducting him and telling him to cease patrols that took jobs away from transit officers, he interpreted their motives with a countercultural vocabulary: "Because they [the authorities] don't control us. They are against anything that they do not control., $\$ 4$

When in 1980, city officials offered the Guardian Angels the possibility of receiving auxiliary police status, Sliwa turned down the deal. "We don't want to act just as the eyes of the transit police and merely report crime," Sliwa explained. "We want to be a real deterrent. We want to be able to make [citizens'] arrests." 85 "I hate to be limited," he declared. "I wanted to be able to get across that it was citizens doing something - no one else — not because they were getting 'mega-bucks' from Washington, D. C. or because they were getting awards." The head of the Transit Patrolmen's Union strongly criticized the Angels as vigilantes who interfered with police work. ${ }^{86}$ In 1981 , Sliwa agreed to issue identification cards to Guardian Angels and engage in better communication with the police department, but did so with anti-elitist tone: "The badges make the New York Times crowd feel good. The people on the subways in Brooklyn never needed to see a badge. They were always happy enough just to see us on the train." ${ }^{87}$ Regarding funding, Sliwa scoffed, "I would die on a dark day in the sewers of New Orleans before I'd accept a penny from the city, state or federal government." ${ }^{\prime} \mathrm{He}$ 
contended that philanthropic foundations would not support the Angels, whom they regarded as "Bedouins and nomads." Instead, the group relied upon small donations from citizens, small businesses, churches, and the occasional celebrity. ${ }^{89}$

\section{Crime Control in an Era of Austerity}

The rise of the Guardian Angels took place within a national turn towards citizen policing - a response to a fear of crime, fiscal cutbacks, and distrust of the police - first officially advocated by the Presidential Commission of 1967 to encourage more active involvement of citizenry in crime prevention as "coproducers of our nation's safety and security." ${ }^{90}$ But, as political scientists Vesla M. Weaver and Charles Decker have found in an analysis of the founding of the Law Enforcement Assistance Administration (LEAA), a federal agency devoted to the "war on crime," funding of community policing favored already powerful interest groups or organizations in white communities, such as the Girl Scouts and the 4-H, rather than the many community crime-control initiatives already active in neighborhoods of color. ${ }^{91}$ Urban League leader Robert Woodson called these priorities "a bait-and-switch game in that they use statistics on urban minority young people to justify appropriations and, when that money is appropriated and spent, it is spent on organizations which do not traditionally serve those communities or constituencies." 92

These selective funding practices reflected a particular nervousness about empowering minority groups, which, according to New York's Mayor Lindsay, "could lead to a problem of vigilantism." ${ }^{, 93}$ Curtis Sliwa also detected the unease about the trustworthiness and true motives of black and brown crime fighters in his analysis of the suspicion of the Angels: "Are they angels or are they devils?" people would wonder. "When are these guys and gals gonna pick up weapons and revert to their roots, their natural instincts? Soon they will become the very people they were claiming to protect people from." 94 The LEAA, then, not only funded the exponential expansion of the criminal justice system, but also disproportionately supported community groups in middle-class white areas, which tended to be conservative promoters of "tough on crime" policies and lobbied for victims' rights, harsher sentencing, and opposed parole. ${ }^{95}$ These community watch groups were likely to be agents of "aggressive order maintenance," effectively "bifurcating the police clientele into those who merit police protection and personalized service and those who do not." 96 In fact, some community policing organizations emerged in hostile reaction to racial unrest, such as the North Ward Citizens First Aid Squad of Newark, founded by Anthony Imperiale, who defended his largely Italian neighborhood during the riots of 1967 with the declaration that "When the Black Panther comes, the white hunter will be waiting." 97

The rise of the Guardian Angels also coincided with a larger movement toward the privatization of policing. New York Times reporter Clark Whelton concluded that terrified citizens "seemed to believe that 'The Muggers had become a highly organized movement" and "had retired from the field of battle to live behind burglar alarms and double-locked doors." ${ }^{, 98}$ But along with neighborhood watch teams and burglar alarms, "the post-1945 period... witnessed a massive growth in private security policing such that private police personnel now outnumber their counterparts in public policing in Britain and North America." 99 This "quiet revolution" responded to street crime where the state had failed, but was also fueled by the social upheaval of the 1960s, as social protest often 
took the form of violent attack on symbols of repression such as banks and corporations. ${ }^{100}$ Private security grew so rapidly that, by 1976 , the 100,000 private security guards in New York City, fifteen times the number ten years prior, constituted a larger number than official cops. ${ }^{101}$

Commenting on this trend, Rubin Herbstman, a former cop, recalled how "there used to be more law at the end of a nightstick than there was in all the law books." He confessed, "I don't like brutality. But something has to be done. The criminals are using the brutality today. Now the people are afraid, and so are the police." ${ }^{\text {102 }}$ Residents of wealthier neighborhoods commonly hired private security guards to patrol their blocks. Karen Brownstein, president of the East $73^{\text {rd }}$ Street Block Association, declared that their private security guards were "creating a little island of safety." "103 One journalist asked an Upper East Side resident why she and her neighbors did not fund more public police by donating their guard's $\$ 25,000$ salary to the city. The woman's response expressed the logic of privatization: "Why should we? We get more protection this way. Our guards are beholden only to us."104

Poorer communities, more directly affected by crime, had little access to such protection. As civil rights leader Whitney M. Young pointed out, Harlemites "cannot afford the luxury of doormen, private guards, and safety devices." ${ }^{105}$ Black commentators, such as Carl McCall, Harlem's representative to the State Senate and eventual State Comptroller, railed against neoliberal approaches. Attacking President Ronald Reagan's speech to a police chief association, McCall noted that "[Reagan] insisted that crime results from the nasty disposition and absent moral code of criminals rather than from social and environmental conditions; just as his free enterprise philosophy results from a lack of initiative rather than externally imposed conditions of deprivation." ${ }^{\text {"106 }}$ City Clerk David Dinkins, elected mayor in 1989, accused the Reagan administration of being "happy with an economic status that leaves huge numbers of teenage Blacks and Hispanics unemployed." Meanwhile, Assemblyman Frank Barbaro asserted that Mayor Koch's policies denied black and Hispanic youth job opportunities, leading to "negative anti-social behavior."107 The Guardian Angels meant to address this disenchantment.

\section{"Catchers in the Savage, Urban Rye": Race and Self-Help}

The Guardian Angels' use of volunteer patrols by youth of color illustrate how an effort to challenge racist stereotypes and alienation could also support a neoliberal interpretation of crime. Lieutenant Governor Mario Cuomo identified racism as the cause of public ambivalence and skepticism towards the Angels: "If they were the sons and daughters of doctors from Great Neck, would people be calling them vigilantes?

Everyone would be giving them medals." ${ }^{108}$ Anthropologists also grappled with the suspicions the Angels engendered: "We might well ask why it is that social concern, charity, and some of the less lethal principles of western civilization cannot wear T-shirts and berets? Public benefactors need not, after all, be confined to costumes consisting of Brooks Bros. [sic] suits. We might ask why it is that the supremely positive human qualities of care, responsibility, duty and concern cannot look at us from differently colored young faces on the subway?"109

Sliwa had his own ideas about race and crime. In an interview, he said, "We had to deal with a lot of stereotyped notions; blacks and Hispanics were usually associated 
with creating criminal conditions." ${ }^{, 10}$ When Sliwa led a protest of 450 Guardian Angels outside Gracie Mansion to push for official recognition, he quipped, "I know that Koch is totally uncomfortable with the idea of a black or Hispanic. . I was going to confront him with 450 of them, but not with everybody screaming in some auditorium where he could walk out. I was going to make Koch go to sleep at night with 450 blacks and Hispanics right under his bedroom window." "111 Sliwa also saw the Angels as a vehicle for shattering stereotypes. "Now we can magnify the fact that Hispanics and blacks are not just good for going out and mugging people and getting sent to Rikers Island," he explained. ${ }^{112}$ "I've seen the most prejudiced of people suddenly embrace somebody that they would never in their life get near and it's not because they're in love with the person: they're in love with the concept....I think the group can do more to heal and rectify racial injustice and racial prejudice than any other organization I've seen.... It shows how different peoples can work together."113

Writing in the conservative National Review, D. Keith Mano agreed: "They arewhat else? - black and Latin Holden Caulfields, catchers of us in the savage, urban rye." ${ }^{114}$ One journalist saw the Angels as an example of self-help to address the failure of top-down, liberal solutions. "[T]he Angels represent a present miracle and potential revolution ... After decades in which professional criminologists have vainly sought to 'reform' their youthful underclass clients, there suddenly emerges a pacifying and healing force from perhaps the least likely quarter of all: the hardened city youth themselves." 115 But a comment from a middle-aged subway rider at the Bloomingdale's Station revealed the persistence of stereotypes: "It's nice to have them around... Usually if you see a bunch of kids that age down here, you toss your wallet at them and run like hell."116 In one case, the Angels' emergence from the same groups the police and the public had been conditioned to criminalize led to fatal results. Guardian Angel Frank Melvin, an African American young man, was shot by police in Newark while patrolling a housing project for the elderly because he was mistaken for a burglar. ${ }^{117}$ The police said that they thought Melvin was running to attack a fellow officer and refused to stop when ordered. Other witnesses said that he did stop and even held his hands above his head. ${ }^{118}$ According to some accounts he was in the process of opening his jacket to reveal the tshirt insignia that identified him as a Guardian Angel, but one patrol member guessed that the sergeant probably shot because he feared the Angel "was going to take out a weapon." "19 Autopsy results contradicted the policemen's account, but a second examination confirmed the police version. ${ }^{120}$ Sliwa attributed this "cold blooded murder" to racism. ${ }^{121} \mathrm{He}$ organized a march on Washington to urge the appointment of a special prosecutor to investigate the shooting, a spectacle that moved one journalist to recall the freedom struggle: "There was something of the movement from another time in what they were doing." ${ }^{, 122}$ A grand jury did not indict. ${ }^{123}$

At the same time, Sliwa often reiterated the prevailing belief that youth of color were primarily responsible for crime. "Young people who were committing the crimesblack, white, Hispanic, whatever color you want to call them," Silva said. "The answer has to come from some kind of symbol, a group made up primarily of young people, the very types who were out there causing the mayhem and creating chaos in the subway system." 124 Sliwa's publication, Street Smart: The Guardian Angel Guide to Safe Living, included images of young people on color hanging out on the sidewalk to illustrate the kinds of "street punks" to avoid (Figure 3). ${ }^{125}$ The Angels were themselves accused of 
employing what one New Yorker called "outdated stereotypes." A black resident of Hell's Kitchen charged, "If they see a black kid sitting on the steps, they think he is a crazy crack dealer." 126 The Angels' complexion did not necessarily change the public's views of youths of color as a whole; the Angels were the exception to the rule: "There are too many other kids of comparable age engaged in the random business of crime... It would seem valid reason for civic celebration that Sliwa has rallied so many others for the primary mission of protecting the defenseless against sneak attack." ${ }^{, 127}$ Even journalists who approved of the Angels deployed racist stereotypes to express their admiration; a Time magazine reporter described "blacks sweeping... like a pack of wolves... sniffing [a well-dressed man] up and down and urinat[ing] in a circle around him" until the Guardian Angels came to the rescue. ${ }^{128}$

On the one hand, the Angels appeared as heirs to the freedom struggle, marching 225 miles from Newark to Washington, DC, and laying down on the sidewalk to protest Frank Melvin's death at the hands of a racist cop in an act of non-violent resistance. ${ }^{129}$ At the same time, however, they contributed to the conservative agenda of law and order politics. For one thing, they offered a kind of bootstrap interpretation for why some people commit crime and others don't. In the words of the director of Los Angeles branch of the Guardian Angels, "If it weren't for the Guardian Angels, [these kids] would be sucked up by that negative, deadly subculture of drugs and crime." ${ }^{130}$ Such an outlook represents a version of the "Just Say No" approach, devoid of attention to structural issues of poverty and unemployment that might lead to crime, or to the cutbacks in programs that would have otherwise occupied urban youth.

The Angels, unlike other leaders in poor communities of color, said little about economic dislocation. ${ }^{131}$ Sliwa took a hard line against using poverty as an excuse for breaking the law, saying, "I don't account crime to the economic situation." In a variation of the trope of the Cadillac-driving welfare queen, Sliwa continued, "[criminals commit] crimes so that they can have four or five chains around their neck, a big Sony portable cassette radio that goes for $\$ 350$, ten pairs of pants, eight shirts, twenty-five different pairs of sneakers to be styling in, money for smoke, drink, or 'coke,' whatever their pleasure may be... These are not crimes to put the bread and butter on the table."132 He aimed to put the "buzzards, crudballs, slimebuckets and vultures out of business." 133 Guardian Angel Lisa Sliwa regularly resorted to language smacking of eugenics: "Let's call them what they are, mutants with chromosome damage," she declared, referring to criminals as a "subspecies. ${ }^{134}$

The Guardian Angels also appealed to nostalgia for an imagined past when citizen initiative and community responsibility alone could deter crime. Sliwa often referred to wanting to "go back to the old values." 135 At a Senate Hearing on Juvenile Crime, Sliwa testified that he had learned "at the knees of my mom and dad... the way it used to be 40 or 50 years ago. They told me of a time when they could walk through the parks; sleep on a tenement roof; ride the subways of New York late at night." ${ }^{\text {136 }}$ Rather than over-relying on police who might not come, Silva believed, "forty or fifty years ago, if someone had broken into somebody's apartment, the whole building would have been alerted. Old women with broomsticks would have been struggling out of their apartments surrounding the apartment." ${ }^{, 137}$ Again, Sliwa claimed economic strain could not excuse crime, citing that there was no crime wave during the Great Depression. What stopped his own grandfather from robbing a grocery store out of desperation? It was "the knowledge that 
if he tried to go out and commit the crime, the citizens in that neighborhood sitting out on the porches late at night would have jumped on top of him."138 Ordinary New Yorkers of color yearned for times when neighbors looked out for each other, and the language of the "good old days" could easily be taken up by conservatives who longed for an era of undisturbed privilege.

\section{The Guardian Angels and Gentrification: Times Square's Restaurant Row}

Sliwa's Angels patrol of Restaurant Row in Times Square exemplifies how they could slip from being an extension of minority self-determination to a limb of conservative social control. Fighting for gentrification became an unlikely role for a bunch of brown teenagers. Significantly, Angels came at the call of middle-class residents and business owners in Times Square who felt that deviants and undesirables were taking over their neighborhoods. As historian Timothy White has shown, the decline of theater-related craft industries in Times Square in the 1960s and 1970s at least partially accounts for a rise in crime in that neighborhood. ${ }^{139}$ Political scientist Alexander J. Reichl notes that in the ensuing decades, Times Square symbolized "for many the plague of crime and drugs and the takeover of central cities by a menacing population of racial and ethnic minorities." 140 In 1988, merchants turned to such "menacing minorities" when they summoned the Angels to Restaurant Row, an area where, according to one journalist, "a catalogue of degradation was open to view: vials and folded bills were squeezed among palms; vague arguments dissolved into unresolved fistfights whose participants were led off by the police; and grizzled older men sidled up to natty teen-age boys and talked in whispers that led to improbable matches."

Unable to secure a strong police presence, restaurant owners asked Angels to scare off troublemakers who discouraged business (Figure 4). ${ }^{142}$ Resorting to the Guardian Angels, a grass-roots response to neoliberal economic policies, embarassed city officials and was, from the perspective of the Block Association, "a bit like having to turn to Donald Trump to fix the Wollman [ice-skating] Rink."143 Thomas Repetto, the president of the Citizens' Crime Commission, echoed, "I feel ashamed that we have a 16year-old kid doing what the city government should do." ${ }^{, 144}$ Restaurateurs invited the Guardian Angels to establish temporary headquarters in a shuttered café, whose owner had closed shop at least in part because "he had had enough of what life on the street had become in recent years." 145 The volunteers were fed around the clock by the local restaurants who supplied 180 meals a week. ${ }^{146}$ "Maybe it will clean the place up, finally," observed the owner of the closed restaurant. "Get some of the whores, some of the druggies, chase them away."

This practice of removing people — such as indigent citizens frequenting a soup kitchen in a nearby church - who might not be doing anything illegal, emerged from middle-class fears and required questionable tactics. One study found that though the area received the city's highest number of crime complaints, the actual incidence of crime in Times Square was quite low, given the vast numbers of people passing through. ${ }^{148} \mathrm{~A}$ related study found that, though suburbanites regularly perceived Times Square as a "ghetto street," referencing its imagined racial and ethnic makeup, white people were the numerically dominant group there at almost all times of day. ${ }^{149}$ According to one sociologist, "For [the middle-class] the loiterers on the street seemed alien, unrestrained by conventional social codes... Most certainly it [racism] enhanced racial stereotypes as 
innocent Blacks and Hispanics on $42^{\text {nd }}$ street were given wide berth by wary whites." The New York Times acknowledged, "Conflicts frequently arise when civilian groups, relying in stereotypical notions of who looks like a criminal, attempt to arrest someone who is in fact not involved in any wrongdoing." ${ }^{.151}$ City officials reflected an awareness of such stereotypes when they wrung their hands about the legality of removing so-called loiterers: "There are, after all, no laws in our society which foreclose standing on public sidewalks to watch those passing by, but on the contrary, the ability to assemble freely is constitutionally protected. The police cannot arrest people simply because they are standing around." 152

Despite the fact that Guardian Angels shared the ethnicity of those often feared, their status as unconventional "police" appealed to merchants who called on them. As Joe Allen, the restaurant owner who spearheaded the solicitation of the Guardian Angels, pointed out, as private citizens, the Angels "have a certain advantage over the police, in the sense that they don't have to read anyone his rights." ${ }^{.153}$ While police were supposedly hesitant to pursue minor violations for fear of being accused of abusing their authority, the Guardian Angels had the freedom to look at the matter more simply. "Possession of crack is prima facie evidence of a crime," Sliwa stated. "Unencumbered by the department's historic fear of letting police police," the New York Post applauded, the Angels "slam-and-jam." 154 The New York Civil Liberties Union objected, but stated that their concern for individual liberties was not meant to single out the Guardian Angels; "We couldn't tolerate the police telling people they shouldn't be on the street simply because they don't fit the profile of restaurant goers," a spokesman explained. ${ }^{155}$ In response to such concerns, a conservative columnist rebutted that "legalism has been the last, and easiest, refuge of scoundrels." He continued, "This is the great, paralyzing liberal canard - that, of government, responsible citizens, absolute perfection is required.... T] his obsession with that one innocent suspect, that one disenfranchised soul, can effectively hamstring and demoralize a civilization." 156

Police expressed frustration with the tactics of the Angels, on the one hand because they could not undertake such work themselves, and on the other because of the disregard for civil liberties. Perhaps defensive about the implications of merchants turning to the Angels, the NYPD took the opportunity to point out that they were hamstrung by court decisions that restricted their practices. ${ }^{157}$ One cop grumbled, "What people don't understand is that our hands our tied.... We look at people, and we know that they're drug dealers, but we're not allowed to go through their pockets or rough them up. We have to have probable cause." "158 Deputy Inspector Edward Fitzgerald of the West $54^{\text {th }}$ Street Station House explained, "There are things that the law says we [police] can't do, but these guys [the Angels] can break faces." He lamented, about the good old days, "This isn't forty years ago, we can't scoop them off the street for just being there. We empathize with the frustrations of the people." ${ }^{159}$ In a strange twist, the police came to the aid of the accused when they arrested two Guardian Angels for menacing a suspected drug dealer. The police asserted that there was no reason to believe that the man was a drug dealer and that he had no criminal record. Furthermore, it was illegal, a commanding officer in the district said, to verbally harass people they suspected of being drug dealers, or even asking them to leave. ${ }^{160}$ As to the Guardian Angels' practice of smashing suspects' crack pipes on the street, Assistant Police Chief Thomas Walsh 
explained, "You can't take somebody's property. You can't confiscate his drugs or break his crack pipe or grind his crack vial into the ground." 161

Sliwa's defense of these tactics not only rejected the ideals of civil liberties but also embraced a masculine-gendered style of intimidation. To his critics, Sliwa scoffed, "We might as well be Gandhi," and claimed, "When you arrest the Angels you emasculate the public." 162 In reference to concerns about the rights of the Angels' targets, the Reverend Dale Hansen of nearby St. Luke's Church and the chairman of the Restaurant Row Association bemoaned that "the absurdity of the civil rights movement is smothering all of us." ${ }^{163}$ When asked whether he was concerned about violating people's civil liberties, he responded with a vision of a world turned upside down: "Prostitutes, crack dealers, drug dealers - as far as I'm concerned, they've violated my rights." 164 Depicting those who counseled therapeutic approaches to crime as effeminate, Sliwa avowed, "When you're facing Uzi-toting, drug-sucking psychopathic killing machines, you're not going to use Joyce Brothers tactics," referring to a famous TV psychologist and advice columnist. ${ }^{165}$

Newspaper accounts testify to this muscular style of intimidation. Angels shoved people, told a young woman with spiky hair to "keep moving," and kicked a woman sleeping in a doorway. ${ }^{166}$ The Angels told a man to leave the area even though he lived there. ${ }^{167}$ Mike McAlary of the Daily News complained that "a half-dozen residents have been searched and chased from their own stoops. Gay men have been mocked and cursed. A dying man has been humiliated." ${ }^{168}$ Several Angels chased down a couple that was smoking marijuana and dumped out the woman's purse. ${ }^{169}$ A new Guardian Angel recruit, just two days in the group, complained to the police of his colleagues' aggressive practices. "90 percent of the time, the Angels go out to fight—not to make busts," he told a New York Post reporter. ${ }^{170}$

Most Angels' targets were not "Uzi-toting killing machines." Journalists noted that "transvestites," often shooed away, did not bother anyone." ${ }^{\prime 17}$ Many residents concurred that drug dealers and users were not particularly dangerous. One commented, "The crackheads are usually pretty well behaved, unsightly but not really threatening... The biggest winners [of the Angels' presence] are the restaurant owners." ${ }^{\prime 12}$ Some leaders in the adjacent Clinton neighborhood also invited Angels to patrol, but others claimed residents and the drug dealers left each other alone. ${ }^{173}$ Theater owner Abe Kaplan offered, "It's not as bad as people believe.... [The drug dealers] don't give us a hard time. I know them. They know me. Some know me by name. If I ask them to move, they will." Some even walked him to the subway. "They're just trying to make a living. Unfortunately, it's the wrong type." ${ }^{174}$ But middle-class visitors expected a destination free of poverty and human distress. One New York Post reader complained about the "urban horror" of witnessing, on his way to a show, a naked man rummaging through garbage: "I can't explain the sense of revulsion that went through me.... I could not find a police officer or a Guardian Angel anywhere on the street.... The paying public should not be subject to this abuse." 175

The Guardian Angels' presence, the controversy it engendered, and the social order it came to promise increased Restaurant Row's appeal as a tourist attraction. ${ }^{176}$ According to area boosters, now that the Angels had arrived, "Normal-looking people walked the block with their heads up." ${ }^{\prime 177}$ Restaurateur Joe Allen said that, thanks to the Angels' vigilance, the street now resembled "a country lane." 
manager said approvingly, "I see little old ladies shopping on the street I never saw before.... Instead of being prisoners in their homes, they're out again." ${ }^{\text {"179 }}$ Without minimizing the sense of safety granted to "little old ladies," one can regard the conversion of a "human sinkhole" into a "country lane" as a gentrification process. When asked about whether the Guardian Angels helped to gentrify the area, a former Angel reflected, "Not intentionally, but one could plausibly say what happened is they played a role in the transition from Times Square to Disneyworld. It probably would have happened anyway, but the Guardian Angels sped up the police responding to that call."180 Sliwa concurs, claiming that the Times Square Business Improvement District, a publicprivate partnership organized in 1990 by powerful private interests to address quality-oflife issues, started at least in part because "they didn't want a group of rag tag kids running around in sneakers doing public safety in Times Square; it was an embarrassment."181 Following the Guardian Angels' patrols, Restaurant Row experienced a renaissance, jammed with "celebrities, politicos, and literati... Meanwhile, the swaggering Angels continue their patrols along West $46^{\text {th }}$, making Hell's Kitchen safe for tortelli alla rustica." ${ }^{\prime 82}$ In 1987, urbanist Marshall Berman mourned the kinds of policies that contributed to "the long term transformation of New York into a place where capital from anywhere in the world is at home, while everybody without capital is increasingly out of place." 183

\section{The Forces of Reaction: The Guardian Angels and The Subway Gunman}

The ultimately conservative tendencies of the Guardian Angels can best be seen in their support of Bernhard Goetz, the white "subway gunman" who in 1984, believing that a group of black teenagers was about to rob him in a subway car, shot them all, rendering one of them brain damaged and paraplegic. Goetz was found not guilty of all charges except for carrying an illegal firearm. The incident sparked a national debate about racism, crime, self-defense, the fairness of the criminal justice system, and the extent to which citizens could rely on the police for protection. Black New Yorkers saw the event as a declaration of "an 'open season' on Blacks and Hispanics" and equated Goetz's actions with a lynching. ${ }^{184}$ Ronald Kuby, who sued Goetz on behalf of one of the shooting victims, and his famed law partner William M. Kunstler, who defended the likes of the Chicago Seven and Assata Shakur, wrote that "Whites are told that it is now lawful for them to capitulate to their own fears, and that complex problems of crime and poverty can be dealt with by blasting away... Black life, already cheapened by years of unpunished police shootings, is further devalued." ${ }^{185}$ Critics of the Goetz outcome traced the episode to a growing "hysteria" about black men in New York City and to the Reagan administration's attack on civil rights. ${ }^{186}$

While it is difficult to discern the opinions of the Angels' rank and file, the Guardian Angels held vigils for Goetz, acted as his bodyguards, and raised money for his defense (Figure 5). ${ }^{187}$ Sliwa spoke at Congressional hearings on the incident, justifying self-protection against the "sleaze and slime" in the subways. ${ }^{188}$ "It's time to stop punishing victims," Sliwa declared, "and start punishing criminals." 189 He claimed that the youths whom Goetz shot were known by the Angels as thugs with criminal records who regularly terrorized people on the number 2 train. In a most bizarre scenario, during the trial, Goetz's defense team recruited four African American Guardian Angels, dressed in jeans and T-shirts, to reenact the roles of the four youths shot by Goetz in order to 
demonstrate just how threatened Goetz must have been. ${ }^{190}$ In the words of one legal scholar, "There is no doubt that the dramatic power of this re-creation of the crime was enhanced by having four street-clad black kids standing in for the alleged aggressors." "191 The Guardian Angels had literally been enlisted by the forces of reaction, this time, to play the roles of menacing black criminals.

Not surprisingly, many black New Yorkers denounced Sliwa's position, chasing him out of Harlem as he arrived to debate a black student on the subject. Lisa Williamson, northeast regional director of the National African Youth Student Alliance, stated, "We don't believe... a European male [should have] free access to the minds and bodies of our young." 192 Some liberal community leaders who had supported the Guardian Angels broke with them over their support of Goetz. Reverend Howard Moody of the Judson Memorial Church in Greenwich Village, for example, who had married Curtis and Lisa Sliwa, now criticized the lack of black and Hispanic leaders within the Angels' organization. "I never understood how a white man in New York could set himself up as the permanent leader of a group of Hispanics," he admitted. ${ }^{193}$ An editorial in the Amsterdam News, expressing disgust with the support for Goetz offered by Roy Innis, the chairman of the Congress of Racial Equality (CORE), described a new perceived alignment. "We now see Blacks joining with whites. Roy Innis now joins Curtis Sliwa who joins the National Rifle Association who joins with the American Right Wing who joins with the conservative columnist, Patrick Buchanan. It is a sorry aggregation of the forces of reaction in our society."194

And yet, Angels claimed to be the heirs of the civil rights movement when facing resistance. When the residents of Mattapan, Massachusetts - a primarily black neighborhood in Boston - complained that members of a new chapter of the Guardian Angels were harassing local black teenagers who were just "hanging out" outdoors, Angel Lisa Sliwa claimed that those who wanted the Angels out were "like the mayor of Birmingham, Alabama saying that the civil rights marchers can't march." "195 Then she railed against the "pimps, punks, and human garbage" on the streets of Mattapan. A journalist remarked, "If any of them were struck by the irony of militaristic zeal coupled with '60s racial platitudes [directed at black liberal politicians]... they weren't letting on." ${ }^{196}$ But this irony is precisely what is intriguing and illuminating about the Guardian Angels. Their anti-establishment tone and their arguments that normal political channels could not solve social problems fit in neatly with both the frustration of the Left and the populism of the New Right, thus demonstrating the complexity of the roots of the punitive turn.

\section{Conclusion}

In the 1990s, Mayor Rudolph Giuliani legitimized the Guardian Angels, sealing their conservative credentials and their enlistment in the forces of social and spatial control. Giuliani's victory rested on his appeal to disaffected white, formerly Democratic voters. He campaigned on a platform of retaking control from welfare recipients, criminals, and the homeless, engaging in a broader politics of reaction to the "theft" of the city by so-called dangerous classes but cloaked in a populist language, championed by the Guardian Angels, of neighborhood security and civic morality. As the middle and upper classes called for increased policing, for their own personal safety, real estate and corporate interests also called for increased policing to maintain the stability of new entrepreneurial spaces. ${ }^{197}$ The Angels' alliance with these interests became clear when 
Giuliani appointed Sliwa to the Decency Commission, an entity created to judge the morality of publically funded art, and even more curiously, appointed Sliwa on a task force on police-community relations. ${ }^{198}$

Many scholars have documented the rise of the carceral state, and some have linked this "culture of control" to privatization, gentrification, and regulation of urban spaces. Such studies concur that mainstream Americans abandoned hope that policies could eradicate poverty and integrate citizens into institutions, and chose to purchase protection and, in the words of Jonathan Simon, "govern through crime." 199 Exploited by politicians both Democratic and Republican, this reaction corresponded to a perceived decline in public morality, blamed on the excesses of liberalism and youth of color. ${ }^{200}$ Other scholars have excavated a more hidden history of black support for punitive policies and "the political mobilization of these communities for greater public safety," offering a bracing reminder that black people have also been "actors in the policies that sustain mass incarceration." $" 201$

Within this landscape, the Guardian Angels stood at a crossroads. They reflected and harnessed the desire for community control, self-determination, and skepticism about the police long-brewing in poor communities of color. At the same time, their practices bolstered a hysteria about a city out of control, a call for more aggressive policing, a rejection of liberalism, and the evacuation of the city's public spaces of undesirables. The Guardian Angels, fitting neither neatly into the political left or right, demonstrate both the convergence and fissures between the concerns of people of color and the conservative backlash that would come to dominate New York City's political culture in the 1990s. The fact that most Guardian Angels went on to occupy three main professions-social work, the military, and law enforcement - suggests that concern about crime held these otherwise contentious constituencies together during New York's fiscal crisis. ${ }^{202}$ The official acceptance of the Guardian Angels clearly suggests an ominous ultimate legacy for their movement; "Diamond," a current Guardian Angel, who is black, confessed in 2014 that he feels safer when he is wearing his red beret, because when he is not in Guardian Angels uniform, he is more likely to get harassed by the police. ${ }^{203}$ 
Figures:

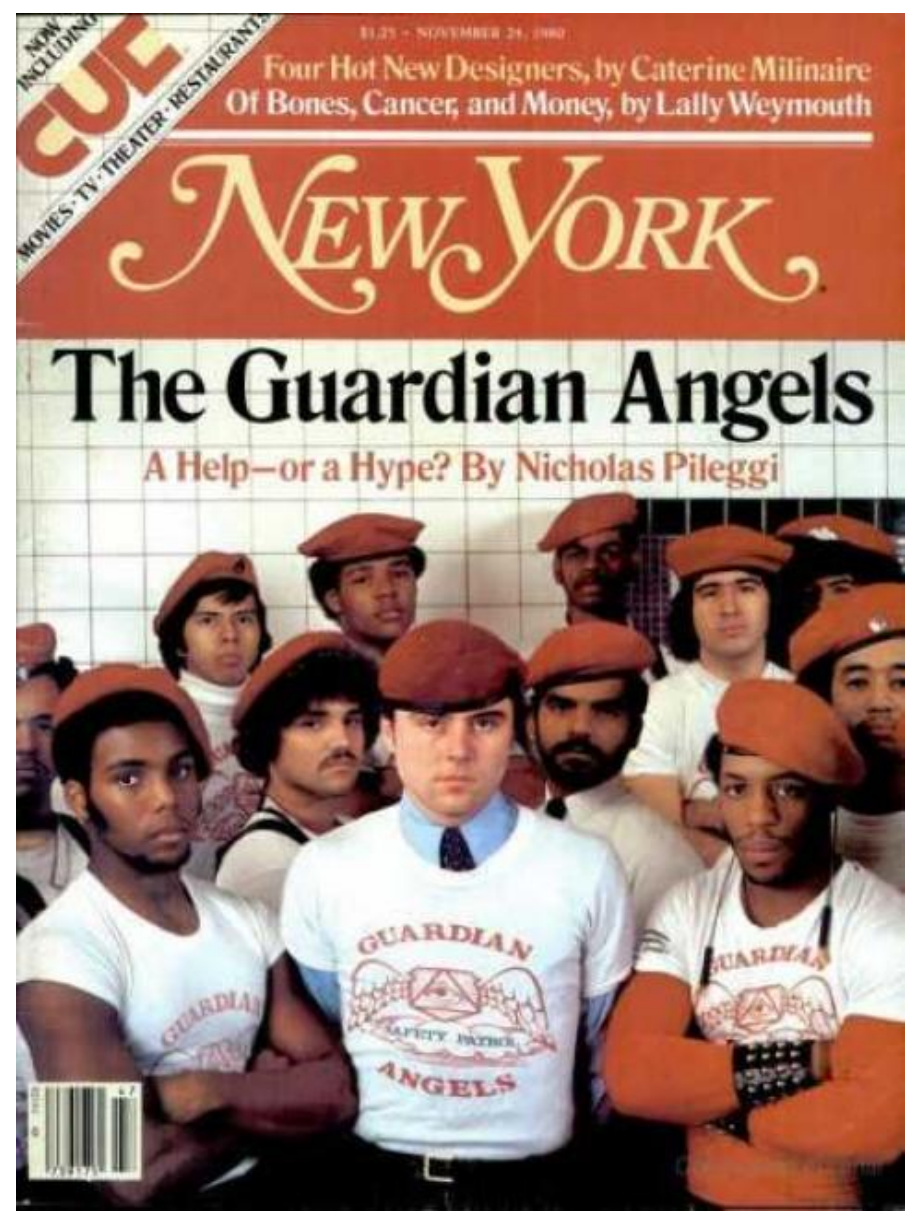

Figure 1. Cover of New York Magazine, February, 1980.

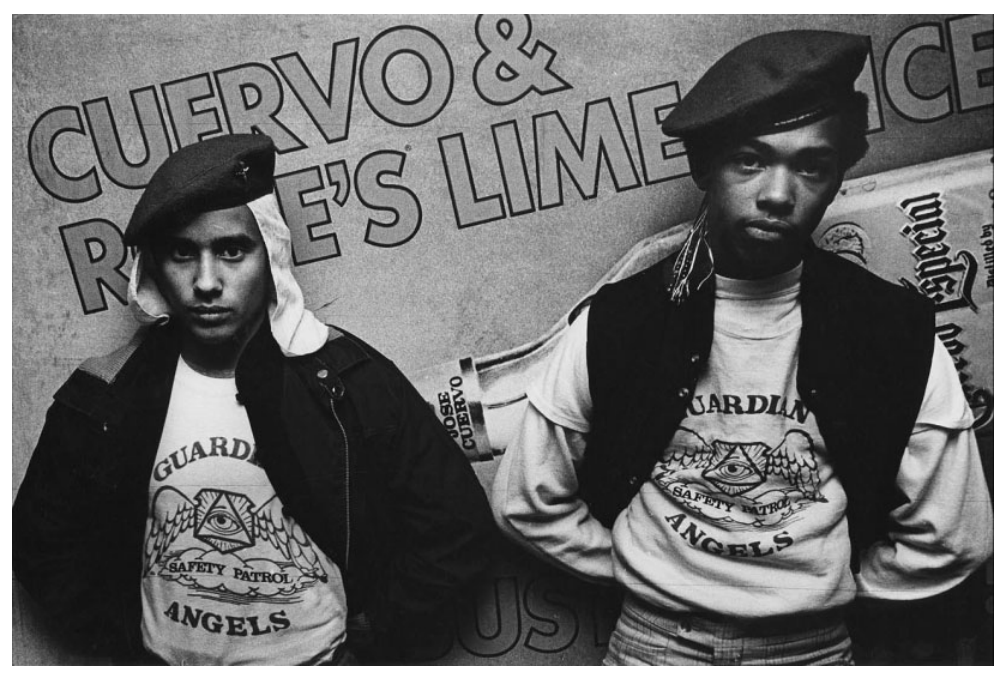

Figure 2. Latino Guardian Angels at a subway stop in the Bronx, 1981. Photograph by Geoffrey Hiller. 


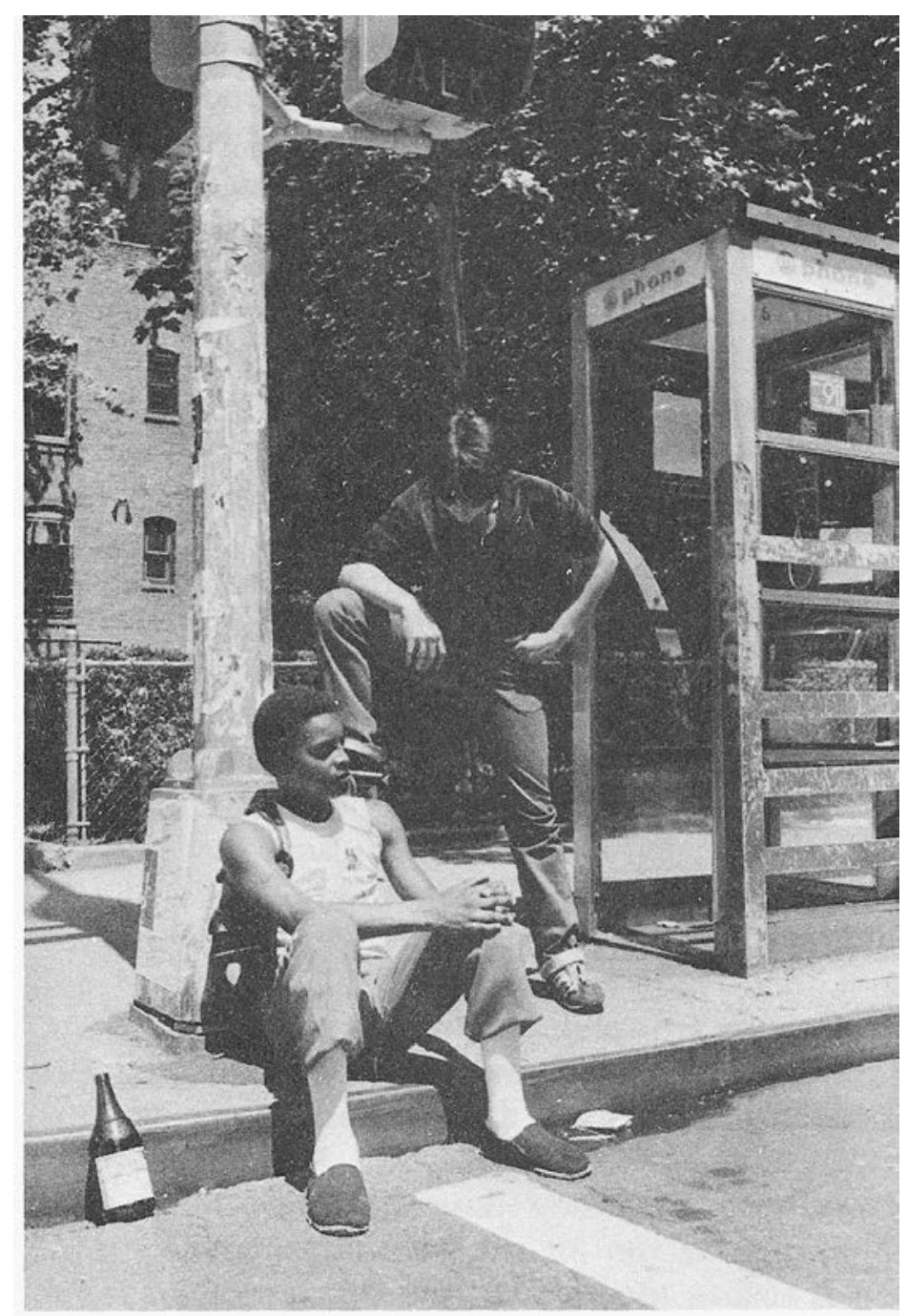

Figure 3. From Curtis Sliwa's 1982 book, Street Smart: The Guardian Angel Guide to Safe Living. The caption in the book reads, "Some inner-city youths, unable to find summer jobs, hang out in public areas, waiting — and sometimes looking - for trouble." Notice the bottle of beer on the sidewalk. 


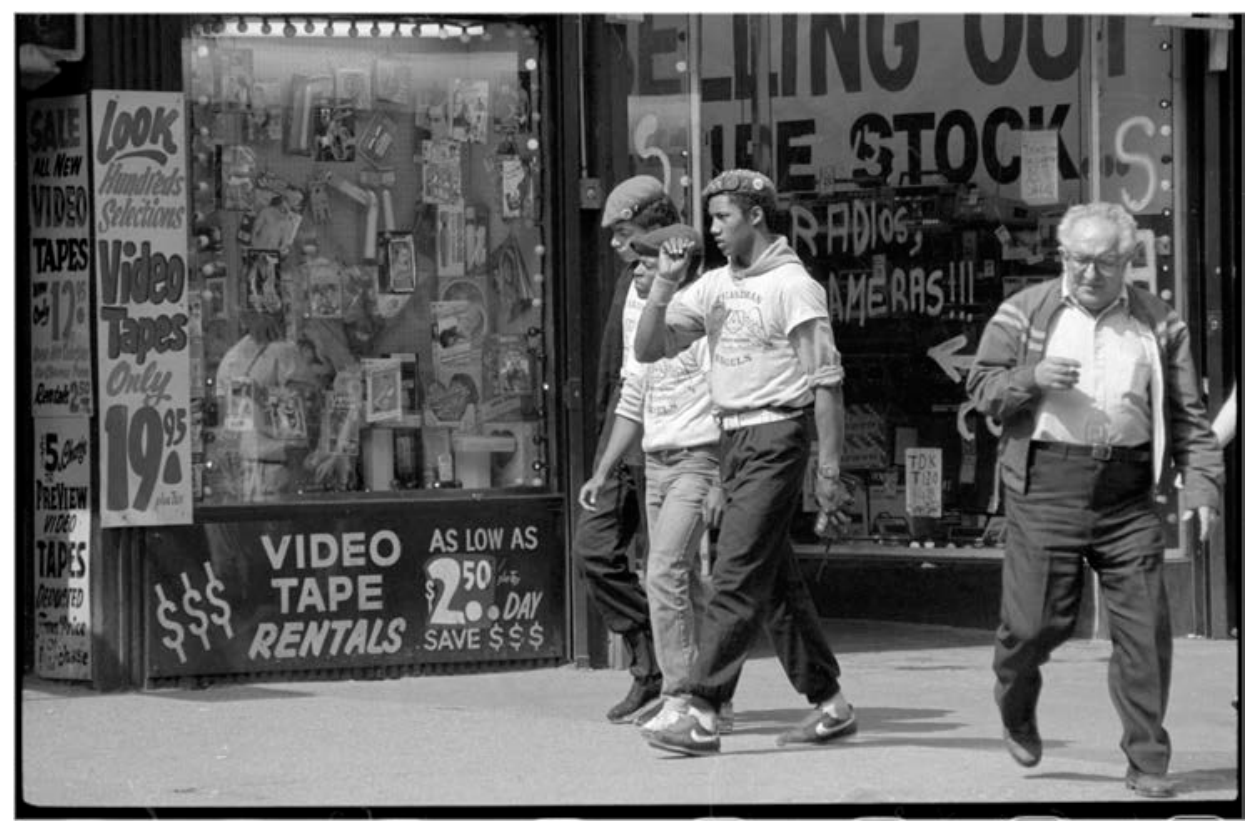

Figure 4. "Angels and Dildos." Guardian Angels patrol Times Square. Photograph by Matt Weber, 1988.

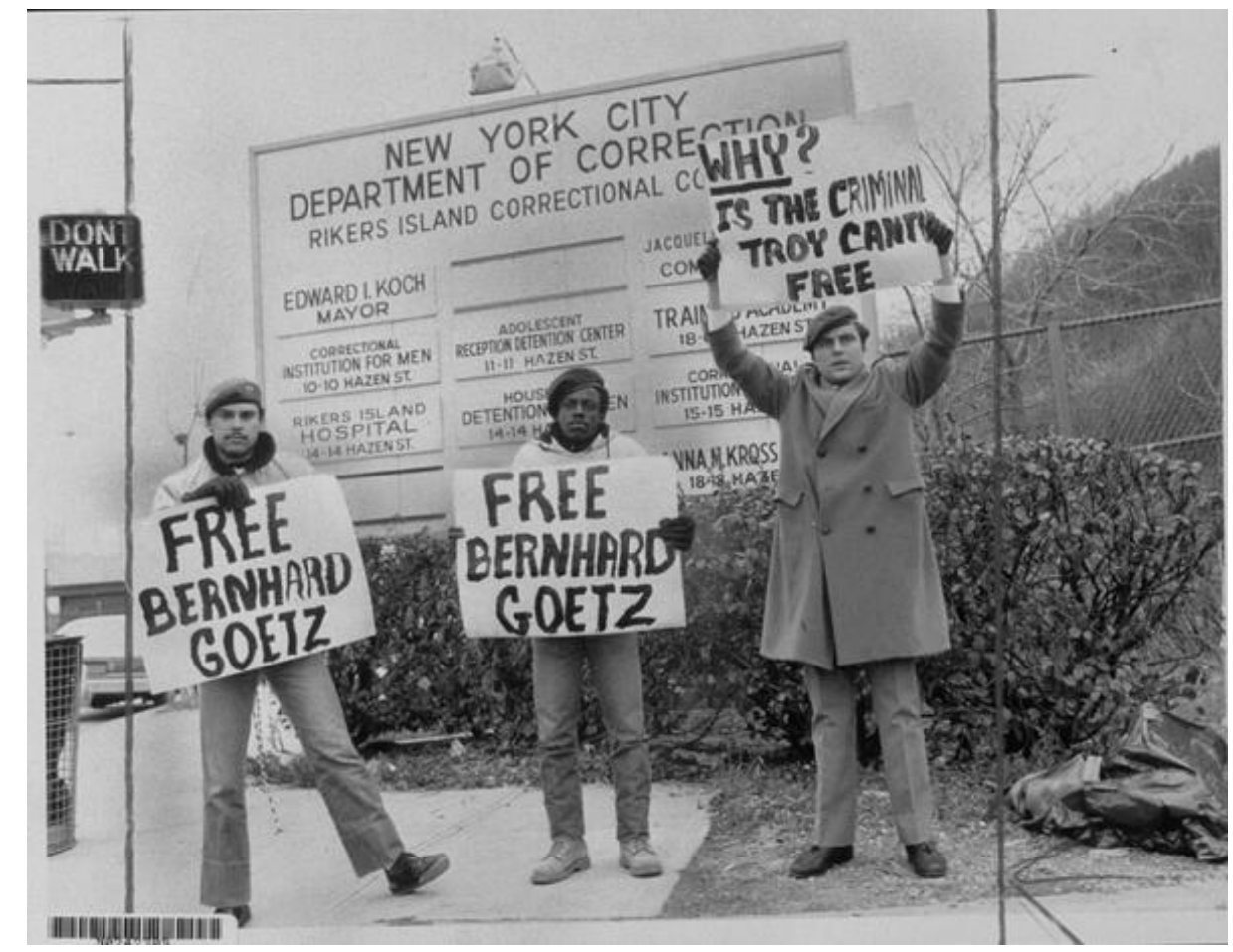

Figure 5. Guardian Angels protest the arrest of Bernhard Goetz on Riker's Island, 1984. Photograph by Rick Maiman. 


\section{Notes}

1 "Crime-Weary New Yorkers Welcome Guardian Angels," Hartford Courant, March 3, 1981, A2.

2 James Haskins, The Guardian Angels (Hillside, NJ: Enslow Publishers, 1983), 18.

${ }^{3}$ Bernard Edelman, "Does New York Need the Guardian Angels?" Police Magazine, May, 1981, 51; “"Guardian Angels': Different Gang,” Washington Post, April 14, 1981, A7.

4 “'Guardian Angels' Patrol a Perilous Beat in New York's Troubled Subway System," Los Angeles Times, January 14, 1981, C6. The Guardian Angels claimed to have made ninety-seven citizens' arrests in their first year, of mostly attempted muggers, purse snatchers, chain grabbers, and pickpockets. "NY Angels watch over transit riders," Chicago Tribune, December 16, 1980, 1.

5 Jere Hester, "Either Right or Wrong: Angels on Patrol, 1980.” in ed. Jay Mader, Big Town, Big Time: A New York Epic, 1898-1998 (New York: Daily News Books, 1999), 172.

6 "Reducing Crime in the New York City Subway System: Nine Recommendations." Project on Urban Transportation, Natural Resources Defense Council, 1979, 1.

Straphangers Campaign Records, Series I, Box 1, Folder 8: "Crime and Police/General, 1984," New York Public Library. According to surveys of subway riders, the most consistent predictors of fear of crime were "being hassled" by youths and graffiti. Vincent Del Castillo, "Fear of Crime in the New York City Subway (PhD diss., Fordham University, 1992), 147-153. On the actual rate of crime on the subways in the 1980s, see Castillo, "Fear of Crime in the New York City Subway," 15-27.

${ }^{7}$ Letter to the Editor, "Whither the Guardian Angels?" New York Times, March 20, 1981, A26.

8 “Crime-Weary New Yorkers Welcome Guardian Angels," A2.

${ }^{9}$ Interview with Curtis Sliwa in Bill Berkowitz, Local Heroes: The Rebirth of Heroism in America (Lexington, MA: Lexington Books, 1985), 155; "In New York, good guys wear red hats," Chicago Tribune, March 23, 1980, 3.

${ }^{10}$ Interview with Arnaldo Salinas, January 5, 2014.

11 "Guardian Angels Go Where Fools Fear to Tread," Los Angeles Times, February 15, 1981, C1. By 1985, the Guardian Angels had spread to over fifty cities in the U.S. and Canada. Susan Pennell, et al. "Guardian Angels: An Assessment of Citizen Response to Crime," San Diego Association of Governments, October 1985, Volume I, Executive Summary, 2. 
12 Jonathan Soffer, Ed Koch and the Rebuilding of New York City (New York: Columbia University Press, 2010), 128, Introduction, and Chapter 17.

${ }^{13}$ On the efforts at urban redevelopment focused on tourism and corporate investment, see Miriam Greenberg, Branding New York: How a City in Crisis Was Sold to the World (New York: Routledge, 2008).

${ }^{14}$ In her 2010 article, "Why Mass Incarceration Matters," Heather Ann Thompson observed that "attempts to grapple with the broad impact of the postwar rise of the carceral state have remained the preserve of journalists, legal scholars, criminologists, and social scientists," and urged historians to take up the issue. Heather Ann Thompson, "Why Mass Incarceration Matters: Rethinking Crisis, Decline, and Transformation in Postwar American History," The Journal of American History 97 (December, 2010): 705. Key works by both historians and non-historians include Michelle Alexander, The New Jim Crow: Mass Incarceration in the Age of Colorblindness (New York: The New Press, 2012); Michael Flamm, Law and Order: Street Crime, Civil Unrest, and the Crisis of Liberalism in the 1960s (New York: Columbia University Press, 2007); Robert Perkinson, Texas Tough: The Rise of America's Prison Empire (New York: Metropolitan Books, 2010); Glen C. Loury, ed., Race, Incarceration, and American Values (Cambridge, MA: MIT Press, 2008); Christian Parenti, Lockdown America: Police and Prisons in the Age of Crisis (New York: Verso, 1999). On the economic root of prisons, see Ruth Wilson Gilmore, Golden Gulag: Prisons, Surplus, Crisis, and Opposition in Globalizing California (Berkeley: University of California Press, 2007); on the role of social movements in the expansion of the carceral state see Marie Gottschalk, The Prison and the Gallows: The Politics of Mass Incarceration in America (Cambridge: Cambridge University Press, 2006); on the role of civil-rights liberalism in fostering the growth of the carceral state, see Naomi Murakawa, The First Civil Right: How Liberals Built Prison America (New York: Oxford University Press, 2014).

${ }^{15}$ George L. Kelling and James Q. Wilson, "Broken Windows," The Atlantic Monthly (March 1982), 29-38.

${ }^{16}$ Alex S. Vitale, City of Disorder: How the Quality of Life Campaign Transformed New York Politics (New York: New York University Press, 2008); Andrew McArdle and Tanya Erzen, eds., Zero Tolerance: Quality of Life and the New Police Brutality in New York City (New York: New York University Press, 2001); Loïc Wacquant, Prisons of Poverty (Minneapolis: The University of Minnesota Press, 2009).

${ }^{17}$ Themis Chronopoulos, Spatial Regulation in New York City: From Urban Renewal to Zero Tolerance (New York: Routledge, 2011), 149. Giuliani summarized his commitment to "broken windows" and "quality of life" as integral to his law enforcement strategy in his address, "The Next Phase of Quality of Life: Creating a More Civil City," delivered February 24, 1998. Viewed online http://www.nyc.gov/html/records/rwg/html/98a/quality.html. 
${ }^{18}$ On poor urban residents as victims of crime, see Paula H. Kleinman and Debora S. David, "Victimization and Perception of Crime in a Ghetto Community," Criminology 307 (1973-1974): 307-343. My study heeds historian Matthew D. Lassiter's call to recognize "the times and places in which liberalism and conservatism have overlapped... [which] requires a reconsideration of the polarization thesis that has animated the scholarship on the New Right." Matthew D. Lassiter, "Political History Beyond the Red-Blue Divide," Journal of American History 98 (2011): 762. On AfricanAmerican leaders' positions on the Rockefeller Drug Laws, see Jessica Neptune, "Harshest in the Nation: The Rockefeller Drug Laws and the Widening Embrace of Punitive Politics," Social History of Alcohol and Drugs 26 (Summer 2012): 170-191; also James Forman, Jr., "Racial Critiques of Mass Incarceration: Beyond the New Jim Crow," New York University Law Review 87 (February, 2012): 101-146; Michael Javen Fortner, "The 'Silent Majority' in Black and White: Invisibility and Imprecision in the Historiography of Mass Incarceration," Journal of Urban History 40 (March, 2014); 252282; and Vesla M. Weaver and Charles Decker, "'The Only Battle in the Nation's History in which the Black Community has not been Enlisted': Black Agency, Resistance, and Alternatives to Incarceration," (paper presented at the annual meeting of the Western Political Science Association, Seattle, WA, April 17-19, 2014), viewed online at http://wpsa.research.pdx.edu/papers/docs/Weaver $\% 20$ Decker $\% 20$ paper $\% 20$ for $\% 20$ the $\%$ 20Western.pdf

${ }^{19}$ Neil Smith, The New Urban Frontier: Gentrification and the Revanchist City (New York and London: Routledge, 1996), 211.

${ }^{20}$ On the concept of a "black silent majority," see Fortner, "The 'Silent Majority' in Black and White."

${ }^{21}$ Fritz Umbach, The Last Neighborhood Cops: The Rise and Fall of Community Policing in New York Public Housing (New Brunswick: Rutgers University Press, 2011), 11.

${ }^{22}$ On cuts to the police department during the fiscal crisis, see Chronopoulos, Spatial Regulation in New York City, 119.

${ }^{23}$ Kim Phillips-Fein, "The Social History of Austerity” (paper delivered at the Urban History Association Conference, New York City, October 25-28, 2012).

${ }^{24}$ In a similar vein, in her book, Safe Space, scholar Christina B. Hanhardt demonstrates how the call for safe streets by LGBT organizations ended up reinforcing the race and class stratification of urban space. Not coincidentally, gay anti-crime street patrols collaborated with and modeled themselves after the Guardian Angels in San Francisco and New York. Christina B. Hanhardt, Safe Space: Gay Neighborhood History and the Politics of Violence (Durham, NC: Duke University Press, 2013); see also Christina B. Hanhardt, "Butterflies, Whistles, and Fists: Gay Safe Streets Patrols and the New Gay Ghetto, 1976-1981," Radical History Review 100 (Winter, 2008): 60-85. 
${ }^{25}$ Susan Pennell, et al, "Guardian Angels: Citizen Response to Crime Prevention," Journal of California Law Enforcement, 20 (1986): 23.

${ }^{26}$ Dennis Jay Kenney, "Crime on the Subways: Measuring the Effectiveness of the Guardian Angels," Justice Quarterly 3 (December, 1986): 489.

27 “Crime-Weary New Yorkers Welcome Guardian Angels,” A2.

${ }^{28}$ Interview with Arnaldo Salinas, January 5, 2014.

${ }^{29}$ Edelman, "Does New York Need the Guardian Angels?" 55-56.

${ }^{30}$ Pennell, et al, "Guardian Angles: Citizen Response to Crime Prevention," 106.

${ }^{31}$ Kenney, "Crime on the Subways," 492.

${ }^{32}$ Haskins, The Guardian Angels, 7.

33 "Crime-Weary New Yorkers Welcome Guardian Angels." Hartford Courant, March 3, 1981, A2; “Guardian Angels: Different Gang.” Washington Post, April 14, 1981, A7.

34 “"Guardian Angels: Different Gang,” A7.

35 “"Guardian Angels: Different Gang," A7.

36 “How Angels’ crusade took wing,” New York Post, Oct. 24, 1980, 37.

37 "Guardian Angels Go Where Fools Fear to Tread," Los Angeles Times, February 15, 1981, C1.

${ }^{38}$ Pennell, et al., "Guardian Angels: An Assessment of Citizen Response to Crime,” 24.

39 “Angels Make it Cool To Care,” Amsterdam News, December 26, 1987, 33.

${ }^{40}$ Interview with Illya Lichtenberg, April 7. 2014.

41 “Vigilantes in New York," Boston Globe, September 23, 1979, 51.

${ }^{42}$ Interview with Curtis Sliwa, January 9, 2014.

43 “'Guardian Angels' Patrol a Perilous Beat in New York's Troubled Subway System," C6. The Guardian Angels were clearly not alone in deterring young people from gang activity; as Eric Schneider has shown, the Black Panthers and the Young Lords may also have acted as routes out of gang life, and attracted youths who might otherwise have joined gangs. Eric C. Schneider, Vampires, Dragons, and Egyptian Kings: Youth Gangs in Postwar New York (Princeton: Princeton University Press, 1999), 223. 
44 “"Guardian Angels': Different Gang," A7. Guardian Angels co-founder Arnaldo Salinas ("13") avers that he would have been a drug dealer, "dead or in jail," had it not been for the Guardian Angels. Salinas tells of a young woman, a prostitute, whom he saved from the clutches of a gang, who became a Guardian Angel, then went on to work for the police department. Interview with Arnaldo Salinas, January 5, 2014. Residents of Harlem and the Bronx supported the Guardian Angels, as evidenced by the fact that the Amsterdam News donated space for an office, and Community Board 1 in the South Bronx, a largely Puerto Rican neighborhood, asked the Guardian Angels to patrol their community. Lisa Sliwa with Keith Elliot Greenberg, Guardian Angels: A Commonsense Defence Handbook for Women (London: Sidgwick and Jackson, 1986), 22; interview with Sobeida Cruz, July 9, 2014.

${ }^{45}$ Interview with Curtis Sliwa, January 9, 2014.

46 “'Guardian Angels' Patrol a Perilous Beat in New York’s Troubled Subway System,” C6.

${ }^{47}$ Interview with Curtis Sliwa, January 9, 2014.

48 “The Atlanta Murders and Black Vulnerability," Amsterdam News, June 20, 1981, A6.

${ }^{49}$ Fortner, "The Carceral State and the Crucible of Black Politics"; Foreman, "Racial Critiques of Mass Incarceration"; Neptune, "Harshest in the Nation"; also, "Silent Black Majority Now Clamoring to Be Heard,” Amsterdam News, July 11, 1970, 1.

50 "Middle-Class Leaders in Harlem Ask Crackdown on Crime," New York Times, December 24, 1968, 25; Billy Rowe, "He said it Anyhow," quoting Roy Wilkins. Amsterdam News, September 12, 1981, 55. For more on Dempsey's role as a vocal supporter of the Rockefeller Drug Laws see Neptune, "Harshest in the Nation." For a closer look at the emphasis on rehabilitation as the goal of black organizations tackling the drug problem, see Samuel Roberts, “'Rehabilitation' as Boundary Object: Medicalization, Local Activism, and Narcotics Addiction Policy in New York City, 1951-1962," Social History of Alcohol and Drugs 26 (Summer 2012): 147-169.

${ }^{51}$ William Tucker, Vigilante: The Backlash Against Crime in America (New York: Stein and Day, 1985), 305. Italics in original.

${ }^{52}$ Studies such as those by Fortner and Foreman address the crucial task of taking seriously the concerns of black people about crime and drug addiction, but it is also important to appreciate that the black community's response to tough-on-crime measures was not universal, and that law-and-order politicians used the support of black hardliners to marginalize dissenting voices. Neptune, "Harshest in the Nation," esp. 177-179, 182. As Neptune has pointed out, black people were divided on the issue of drugs, but most called for better rehabilitation services while some even called for drug legalization. See, for example, "Bronx News," Amsterdam News, August 8, 1970, 25. For public outcry 
over tough on crime measures such as a new law that allowed juveniles to be tried as adults, see "Repeal Juvenile Offenders Law," Amsterdam News, January 27, 1979, 20; "Juvenile Offenders Law," Amsterdam News, February 10, 1979, 17; for opposition to bail legislation that would limit a judge's options in setting bail for suspects, a bill which, according to Assemblyman George W. Miller, amounted to "preventative detention for Blacks and Hispanics, as well as the presumption of their guilt," see "Miller Challenges Koch," Amsterdam News, April 28, 1979, 46.

${ }^{53}$ Weaver and Decker, "The Only Battle," 18.

54 "Politics of Fear," Amsterdam News, November 21, 1970, 18; "Shifting to the Right," Amsterdam News, October 31, 1970, 19.

55 “Blacks need to find means of survival," Amsterdam News, November 14, 1981, 17.

${ }^{56}$ Blauner, quoted in Eugene McLaughlin, "Black Cops, Inc." in eds., Ellis Cashmore and Eugene McLaughlin, Out of Order? The Policing of Black People (Routledge: London and New York, 1991), 89.

57 “Police: The Hostile Army," Amsterdam News, June 29, 1985, 12.

58 “Crime in Harlem Streets," Amsterdam News, October 24, 1970, 19.

${ }^{59}$ Uptown: The Voice of Central Harlem, April 1983, 6.

${ }^{60}$ Greenberg, Branding New York, 140. Felix Umach has shown that residents of New York City's public housing complexes wanted their fair share of municipal services, including police protection, and understood their demands in terms of civil rights. Umach, The Last Neighborhood Cops, 6.

${ }^{61}$ Elsie L. Scott, "Black Attitudes Toward Crime and Crime Prevention," in eds. Lee P. Brown and Lawrence F. Gary, Crime and its Impact on the Black Community (Washington, DC: Howard University Institute of Urban Affairs and Research, 1975), 14, 22.

${ }^{62}$ Uptown: The Voice of Central Harlem, 6.

63 “Community Involvement: Citizens Must Fight Black on Black Crime," Ebony Magazine, August, 1979, 113-114.

${ }^{64}$ Interview with Illya Lichtenberg, April 7, 2014.

65 “Reagan's crime war method 'heartless," Amsterdam News, October 24, 1981, 19. 
66 "We Can Prevent Crime," Office of Community Anti-Crime Programs of the Law Enforcement Assistance Administration, United States Department of Justice, 1979, not paginated.

67 "Youth Patrols And..." Amsterdam News, December 5, 1970, 18; "Corpsmen Start Harlem Patrols," New York Times, March 21, 1968, 32. The lack of sanitation services was one of the main complaints of Harlem residents. See "Rev. Weston Asks Mayor to Clean Up Slum Sites," Amsterdam News, February 7, 1970, 29; "Crime In Harlem Gives 'Tobacco Road' Image," Amsterdam News August 29, 1970, 1; Michael "Cetawayo" Tabor, Black Panther Party Pamphlet, "Capitalism Plus Dope Equals Genocide," 4. Black Panther Party, MG 80, Box 1. Folder 19, "New York Chapter and New Jersey, Printed Material." Schomburg Center for Research in Black Culture. Sometimes the frustration of neighborhood residents at the neglect of city services resulted in violent uprisings. "After the Violence, City Sweeps Clean: Brownsville Blasts Off On Garbage Bit," Amsterdam News, June 20, 1970, 25.

68 "Fear Is Steady Companion Of Many Harlem Residents," New York Times, January 3, 1971, 41. Also see "Armless Citizens On Patrol," Amsterdam News, December 5, 1970, 1.

69 "Kenyatta's war against crime, drugs," Amsterdam News, June 30, 1979, 7.

70 "Youth Gangs Are Trying an About-Face," New York Times, February 9, 1977, 25.

71 “The People's War Against Crime," U.S. News and World Report, July 13, 1981, 54.

72 "Blacks Pursue More Active Role In Dealing With Crime By Blacks," New York Times, November 9, 1980, 1.

73 "Roy Wood's One Black Man's Opinion," Amsterdam News, June 20, 1981, A3. One such crime-watch group, the Brooklyn Observation Alliance, made up of 13-17 year-olds, patrolled in the Bedford-Stuyvesant and Crown Heights. Resembling the Guardian Angels, the group's attire consisted of black pants and matching jackets and berets. "B'klyn Youths Form Crime Watch Group," Amsterdam News, May 22, 1982, 9. Selfhelp could result in clashes with the police, as when Black Muslims raided a crack house and the police arrested the Muslims. "Community Calls for Jahid [sic] against crack," Amsterdam News, February 28, 1987, 30.

${ }^{74}$ Interview with Curtis Sliwa, in Berkowitz, Local Heroes, 153. On the importance of community control to black political thought and activism during this era, see Donna Murch, Living for the City: Migration, Education, and the Rise of the Black Panther Party in Oakland, California (Chapel Hill: University of North Carolina Press, 2011); Robert O. Self, American Babylon: Race and the Struggle for Postwar Oakland (Princeton: Princeton University Press, 2005); Jerald E. Podair, The Strike that Changed New York: Blacks, Whites, and the Ocean Hill-Brownsville Crisis (New Haven: Yale University Press, 2004). 
75 “A Way to Remember Frank Melvin,” New York Times, January 5, 1982, A14.

76 “N.Y. Police Say Angels Aren't Heaven-Sent," Hartford Courant, October 10. 1980, B11; "RR Police Say No To Patrols By Angels," Newsday, December 20, 1980, 6; Hester, "Either Right or Wrong"; Pennell, et al., "Guardian Angels: An Assessment of Citizen Response to Crime," 15.

77 “Angels a 'Lynch Mob’-Ward,” New York Post, July 14, 1988, 7.

78 “Angels a 'Lynch Mob’-Ward,” 7.

79 "N.Y. Police Say Angels Aren't Heaven-Sent,” B11; “13 Angels arrested in wild riot with subway cops." New York Daily News, February 14, 1981; "Arrest 11 Angels in row with cops," New York Daily News, February 14, 1981, 3; “Two More 'Angels' are nabbed by transit cops," New York Post, February 16, 1981, 11.

${ }^{80}$ Angela Chema, "The Philosophy of an Archangel: KI Talks with New York Guardian Angel Founder Curtis Sliwa," Karate Illustrated, December, 1982, 24.

${ }^{81}$ Interview with Curtis Sliwa, January 9, 2014.

82 “Angels a 'Lynch Mob'-Ward,” 7.

${ }^{83}$ R. Puri and D. Williams, Special Issue II, "On the Guardian Angels," Journal for the Anthropological Study of Human Movement 2 (Spring, 1982): 38.

84 "Guardian Angel Chief Reports His Abduction by 3 Men in the Bronx," New York Times, October 21, 1980, B2; quotation, "Angels are Harping on Killing," New York Daily News, January 4, 1982, 12. News reports detail other conflicts between police and the Guardian Angels, such as a 1983 case when one black member of the Guardian Angels was arrested on allegedly trumped up charges just when he was about to testify at a federal hearing on allegations of police brutality against black and Latino youth ("Calls Rape Charge a gag ploy in cop probe,” Amsterdam News, July 23, 1983, 9). In 1981, after several Guardian Angels were arrested in a subway melée, some for fare evasion and breaking into token booth, the Angels staged a march from Columbus Circle to Brooklyn with their hands tied together with rope in symbolic protest ("Angels Say Role Riding Subways Hinges on Public.” New York Times, February 17, 1981, B7).

85 "N.Y. Angels watch over transit riders," 1.

86 "Union chief terms offer to Angels 'media hype,"” Yonkers Herald Statesman, October 18, 1980, A4.

${ }^{87}$ Jimmy Breslin, "N.Y. Angels fight like devils to get sanction," Chicago Tribune, June 6, 1981, 9 . 
88 "Angels of the Threatened," Hartford Courant, April 20, 1981, A15. In 1982, the national organization received $\$ 74,670$ in contributions; in 1983, \$83,269, and 1984 \$35,390. Pennell, et al., "Guardian Angels: An Assessment of Citizen Response to Crime Control," Association of Governments (San Diego: 1985), Volume II, Technical Report, 137.

${ }^{89}$ Interview with Curtis Sliwa, January 9, 2014; Pennell, et al., "The Guardian Angels: An Assessment of Citizens' Response to Crime Control," Volume I, 21.

${ }^{90}$ Paul J. Lavrakas and Elicia J. Herz, "Citizen Participation in Neighborhood Crime Prevention," Criminology 20 (November 1982): 480. A National Neighborhood Watch Program was initiated in 1972 by the National Sherriff's Association. Laura Akers, "Private Citizens: Allies of Justice?" Criminal Justice Journal (Summer 1984): 251-274; "When It's Nice to Have Nosy Neighbors," McCall's, July, 1981, 37. Crime watch groups flourished even as LEAA funding for them was being dismantled. "When Citizens Mobilize Against Crime," U.S. News and World Report, January 21, 1980, 49-51; "The People's War Against Crime," U.S. News and World Report, July 13, 1981, 53-54. When compared to other citizen volunteer crime prevention groups nationally, the Guardian Angels were $32 \%$ white whereas other groups were $94 \%$ white; $59 \%$ of Guardian Angels had less than a high school education whereas $43 \%$ of members of other groups had four or more years of college; and the annual income of 38\% Guardian Angels was less than $\$ 5,000$ whereas $62 \%$ of members of other volunteer groups was $\$ 825,000$ or more. Pennell, et al., "Guardian Angels: An Assessment of Citizen Response to Crime Control," Volume II, 128-129.

${ }^{91}$ Weaver and Decker, "The Only Battle,"” 33-44. For more on the "war on crime," see Jonathan Simon, Governing Through Crime: How the War on Crime Transformed American Democracy and Created a Culture of Fear (New York: Oxford University Press, 2009), 90-94.

${ }^{92}$ Woodson quoted in Weaver and Decker, "The Only Battle," 36.

${ }^{93}$ Mayor John Lindsay of New York, quoted in Weaver and Decker, "The Only Battle," 31.

${ }^{94}$ Interview with Curtis Sliwa, January 9, 2014.

95 Akers, "Private Citizens: Allies of Justice?" 267-8.

${ }^{96}$ Stephen D. Mastrofski, “Community Policing as Reform: A Cautionary Tale,” in eds. Carl B. Clockars and Stephen D. Mastrofski, Thinking About Policing: Contemporary Readings (New York: McGraw-Hill, 1991), 519, 522.

97 “When Citizens Mobilize Against Crime,” 50; “Anthony Imperiale, 68, dies; Polarizing Force in Newark," New York Times, December 28, 1999, B9. Two more federal 
initiatives in 1977 and 1980 provided funds directly to community organizations to help mobilize citizens in the fight against crime. Dennis P. Rosenbaum, "Community Crime Prevention: A Review and Synthesis of the Literature," Justice Quarterly 5 (September 1988): 324-325. The case of George Zimmerman's murder of Trayvon Martin and Zimmerman's participation in a Neighborhood Watch suggests the legacy of such a genealogy.

98 “In Guards We Trust,” New York Times Magazine, September 19, 1976, 21.

${ }^{99}$ Nicholas Fyfe, “Policing the City,” Urban Studies 32 (May, 1995): 767.

${ }^{100}$ Michael T. Klare, "Rent-a-Cop: The Boom in Private Police," The Nation, November $15,1975,487$.

${ }^{101}$ By 1976, private security services had become a $\$ 12$ billion industry, growing at what the Rand Corporation called a "recession-resistant average rate of 10 to 15 per cent annually.", "In Guards We Trust," 21. The provision of private security services was dominated by a handful of companies: Pinkerton, Burns, Walter Kidde \& Co, and Wackenhut. Klare, "Rent-A-Cop," 487. Large corporations were not the only entities to hire private security; in 1989, the Third Avenue Merchants Association in the South Bronx hired a three-man force for $\$ 75,000$. The Grand Central Partnership, a coalition of companies located around the railway terminal, spends $\$ 1$ million a year in the late 1980s, hiring twenty-seven uniformed, unarmed, as well as plain clothes guards to pursue drug dealers, luggage hustlers, illegal peddlers, suspicious shoeshiners and three-card monte operators. Alan Breznick, "Self-Protection as Last Resort," Crain's New York Business, July 3, 1989, 1.

102 "In Guards We Trust," 41.

${ }^{103}$ Randy Young, "Putting A Guard On the Block," New York Magazine, February 8, $1982,36$.

104 "In Guards We Trust," 41.

105 “The Crime Problem," Amsterdam News, August 22, 1970, 4.

106 “Reagan's crime war method 'heartless,"” 19.

107 "Unemployment: Hell for minorities," Amsterdam News, September 19, 1981,4; Editor's Notes, Uptown: The Voice of Central Harlem, Summer Issue, 1982, 2.

${ }^{108}$ Hester, "Either Right or Wrong," 172.

${ }^{109}$ Puri and Williams, "On the Guardian Angels," 44-45.

${ }^{110}$ Penthouse Interview with Curtis Sliwa, Penthouse Magazine, August, 1982, 110. 
${ }^{111}$ Breslin, "N.Y. Angels fight like devils to get sanction," 9.

${ }^{112}$ Breslin, "N.Y. Angels fight like devils to get sanction," 9.

${ }^{113}$ Puri and Williams, "On the Guardian Angels," 28.

${ }^{114}$ D. Keith Mano, “Guardian Angels.” National Review, December 30, 1988, 55.

115 "Angels of the Threatened," A15.

116 “'Guardian Angels' Patrol a Perilous Beat in New York’s Troubled Subway System,” C6.

117 “Guardian Angel is Killed by an Officer in Newark," New York Times, January 1, 1982, 26; "Death of 'Angel' Will Be Studied By a Prosecutor," New York Times, January $2,1982,19$.

118 “A cold-blooded murder: Sliwa,” New York Daily News, January 1, 1982, 3.

119 “Sliwa Rages Over Fallen Angel,” New York Post, January 1, 1982, 10.

120 "Autopsy said to differ with police on 'Angel," Chicago Tribune, January 3, 1982, B8; "Prosecutor Calls Data Consistent in 'Angel' Death," New York Times, January 7, 1982, B2.

121 “A cold-blooded murder: Sliwa," 3; "Police Blame Aloofness in Angel's Death," New York Times, January 17, 1982, NJ1.

122 “Inquiry by F.B.I. Starts in Newark In 'Angel' Death," New York Times, January 6, 1982, B1; “Angels are Harping on Killing,” New York Daily News, January 4, 1982, 12.

123 “Officers Cleared By a Grand Jury in 'Angels' Case.” New York Times, February 5, 1982, B2.

${ }^{124}$ Chema, "The Philosophy of an Archangel, 24.

${ }^{125}$ Curtis Sliwa and Murray Schwartz, Street Smarts: The Guardian Angel Guide to Safe Living (Reading, MA: Addison-Wesley Publishing Company, 1982), 38.

126 "An Angel Stabbed in Street Fight; How Violence Began in Midtown Questioned," New York Times, June 18, 1988, B1.

127 “Cops should accept the Angels as partners.” New York Post, February 17, 1981, 11. 
${ }^{128}$ James Wilde, "In New York City: Down Under with the Red Berets," Time, May 7, 1979,6 .

129 “Guardian Angels Mourn at White House," December 30, 1982, UPI Archives, viewed online at http://www.upi.com/Archives/1982/12/30/Guardian-Angels-mourn-atWhite-House/2736410072400/

${ }^{130}$ Mano, “Guardian Angels," 55.

${ }^{131}$ The one possible exception to this interpretation was the Angels' activities on behalf of the homeless, but they did not connect the plight of the homeless to economic restructuring, unemployment, or crime. "Guardian Angels Seized in Protest at Shurz Park," New York Times, October 4, 1982, B3.

${ }^{132}$ Interview with Curtis Sliwa, January 9, 2014.

133 “Sliwa Scores Big in Schenectady.” Knickerbocker News, April 5, 1985, 1.

134 "Sliwa Cites Freedom of Self-Defense." Oswego Palladium-Times, March 9, 1988, 3, viewed online at

http://www.fultonhistory.com/Process\%20small/Newspapers/Oswego $\% 20$ Palladium/Osw ego $\% 20$ Palladium $\% 20$ MarchApri1\%201988\%20pdf/Newspaper\%20\%20Oswego\%20Palladium\%20MarchApril\%201988\%20-\%200108.pdf; Sliwa, Guardian Angels: A Commonsense Defence Handbook for Women, 39.

135 “'Guardian Angels' Patrol a Perilous Beat in New York’s Troubled Subway System," C6.

${ }^{136}$ Hearing Before the Subcommittee on Juvenile Justice of the Committee on the Judiciary United States Senate, July 9, 1981, 4.

137 Ibid, 8.

${ }^{138}$ Ibid, 15. Research on community policing suggests that this appeal was not unique to Sliwa. According to Stephen D. Mastrofski, "community policing has appeal because....it responds to an affection for less conflict and personalized treatment of an imagined past. In a broader sense, community policing taps a nostalgia for the U.S. democratic grassroots tradition of citizen initiative and melds it with impatience with an unresponsive law and cumbersome government bureaucracy." Mastrofski, "Community Policing as Reform: A Cautionary Tale," 515.

${ }^{139}$ Unfortunately, however, White sometimes conflates crime and adult entertainment, which are not the same thing. Timothy R. White, Blue-Collar Broadway: The Craft and Industry of American Theater (Philadelphia: University of Pennsylvania Press, 2015), pp. 162-200. 
${ }^{140}$ Alexander J. Reichl, Reconstructing Times Square: Politics and Culture in Urban Development (Lawrence: University Press of Kansas, 1999), 44.

141 “Times Sq. By Night: Lurid Drama Beckons,” New York Times, June 20, 1988, B1.

142 The restaurateurs of Restaurant Row were part of the $45^{\text {th }}$ Street Block Association, formed in the 1970s. http://west45thstreetblockassociation.org/about/. The Mayor Abraham Beame had tried to invigorate police presence in the area in 1978 with Operation Crossroads. Reichl, Reconstructing Times Square, 59.

143 “Police Dilemma on Restaurant Row." New York Times, June 14, 1988, B2.

144 “Police Dilemma on Restaurant Row," B2.

145 “Angels Fight the Addicts on New York's Restaurant Row." New York Times, June 12, 1988, E8.

${ }^{146}$ Sliwa's description of the volunteers' experience underscored the populist image of the Angels: "Years ago it was Dumpster delights.... Roy Rogers and Burger King used to put food on the top of the bin when they closed. Now the guys are getting food they can't even pronounce." "Dining With The Angels," New York Magazine, July 18, 1988, 15.

147 “Angels Fight the Addicts on New York's Restaurant Row." Inside the café, a Guardian Angel called "Ace" pointed to 102 plastic cigarette lighters displayed on the bar as trophies taken from crack dealers. "Dining With The Angels," 15.

148 Jennifer Hunt, "Crime and Law Enforcement in the Bright Light District," in ed., William Kornblum, "West $42^{\text {nd }}$ Street: The Bright Light Zone," unpublished study, City University of New York, 1978, 170.

${ }^{149}$ William Kornblum and Vernon Boggs, "The Social Ecology of the Bright Light District," in Kornblum, ed. "West $42^{\text {nd }}$ Street," 21.

${ }^{150}$ Lynne B. Sagalyn, Times Square Roulette: Remaking the City Icon (Cambridge, MA: The MIT Press, 2001), 20.

151 “The Perilous Right of Citizens to Make Their Own Arrests," New York Times, June 19, 1988, E8. Reichl analyzes how the language used by real estate interests was saturated with racial anxiety and easily blurred "hustling" with "hanging out," implying that "African Americans, Latinos, and whites cannot share the same entertainment district because non-Latino whites are unable to distinguish the criminal element from among a crowd of African Americans and Latinos." Reichl, Reconstructing Times Square, 63.

152 Times Square Draft Environmental Impact Statement, quoted in Sagalyn, Times Square Roulette, 19. 
153 " $46^{\text {th }}$ Street 'Restaurant Row' Starts Guardian Angel Patrol," New York Times, June 10, 1988. The Fourth Amendment, prohibiting unreasonable searches and seizures, does not apply to private parties, only to state and government officials. Freedom from such procedural restrictions enables people unassociated with official administration to seize evidence, but such independent liberty has potential for abuse. Akers, "Private Citizens: Allies of Justice?" 257. As explained in a New York Times article, in reference to private security guards, "This apparent loophole in the laws protecting the rights of the accused could very well have a widespread impact on criminal justice proceedings in America, since a 'good' guard will not hesitate to use his power of citizen's arrest." "In Guards We Trust," 34.

154 “Guardian Angels Seek Good Old Days.” New York Post, June 21, 1988, 4.

155 "Police Dilemma on Restaurant Row," B2.

${ }^{156}$ Mano, "Guardian Angels,” 55.

${ }^{157}$ While the Supreme Court's decision in Terry v. Ohio (1968), by establishing the right of police officers to stop and detain a person when they have "reasonable suspicion" of his or her involvement in criminal activity paved the way to the dramatic upsurge of "stop and frisk" in the 1990s and 2000s, other ensuing cases interrupted this potentially expansive power. A significant court decision that limited the power of the police to arrest "disorderly" people was Papachristou v. Jacksonville (1972), which overturned a Jacksonville vagrancy law and held that people could only be arrested for their conduct and not their status. Other court cases consequential for "order maintenance" were Coates v. City of Cincinnati (1971), which overturned a vague statute prohibiting groups of people congregating on a sidewalk and Kolender v. Lawson (1983), which prohibited the practice of police demanding identification of supposed loiterers. Soffer, Ed Koch, 270, and Vitale, City of Disorder, 58. One response to these limitations on the police was the privatization of space, as well as of the police. Police Commissioner Benjamin Ward explained, "In New York City, the solution has been to sell public places to the private sector. In Grand Central Station there is a private enterprise zone paid for by businessmen in the area. Within the private enterprise zone, retired police officers are hired to get rid of public nuisances." Benjamin Ward, with Linda Lee, "Top Cop" [unpublished manuscript] Commissioner Benjamin Ward Papers, Special Collections, Lloyd Sealy Library, John Jay College of Criminal Justice/CUNY, 168.

158 "Anger Grows on West $46^{\text {th }}$ St. Between Police and 'Angels," New York Times, June 14, 1988, A1.

159 “Angels Can Do Better Job than Cops.” New York Post, June 11, 1988, 5.

160 “Anger Grows on West $46^{\text {th }}$ St. Between Police and 'Angels," A1.

161 “Anger Grows on West $46^{\text {th }}$ St. Between Police and 'Angels,"” A1. 
162 "Angels Raise Holy Hell Over Cops," New York Post, June 14, 1988, 4; "Anger Grows on West $46^{\text {th }}$ St. Between Police and 'Angels,"” A1.

163 “Dirty war by Angels irks Koch,” New York Daily News, June 15, 1988, 27.

164 “Couple Cleared: Angels Pounce at $47^{\text {th }}$ Street, New York Daily News, clipping, date unknown, viewed online at http://west45thstreetblockassociation.org/wpcontent/uploads/1988/06/88_Dnews_Angels-Cops_patrol.pdf

165 “Angels a 'Lynch Mob'-Ward,” 7. Dr. Joyce Brothers was a famed psychologist who wrote an advice column in Good Housekeeping and other newspapers for decades. Julilly Kohler-Hausmann has similarly pointed out that proponents of law and order policies cast welfare programs and social scientists that subscribed to systemic explanations for social deviance as feminine, and that that a more punitive approach was a restoration of "manliness" to state functions. Julilly Kohler-Hausmann, " "The Attila the Hun Law': New York's Rockefeller Drug Laws and the Making of ta Punitive State," Journal of Social History 44 (Fall, 2010): 78, 80, 84.

166 "Angels Fight the Addicts on New York's Restaurant Row." New York Times, June 12, 1988, E8; "Dirty war by Angels irks Koch," 27.

167 “Anger Grows on West $46^{\text {th }}$ St. Between Police and 'Angels," A1.

168 “The Red Berets are Mad Hatters.” New York Daily News, June 15, 1988, 4.

169 "Couple 'Cleared."

170 “3 Angels Busted After Scuffle with Cops.” New York Post, July 20, 1988, 14. During the first six weeks of patrolling the area, twenty-two Guardian Angels were arrested, and Police received about 20 complaints in a month from residents of the neighborhood. "Police and Guardian Angels Continuing Confrontations." New York Times, August 4, 1988, B3; "11 Guardian Angels Arrested in a Dispute With 2 Officers." New York Times, July 13, 1988, B1.

171 “Men and Boys on Restaurant Row," New York Times editorial, June 15, 1988, A30.

172 “The New Show Off Broadway: 46 ${ }^{\text {th }}$ Street,” New York Times, June 15, 1988, B1.

${ }^{173}$ On welcoming the Guardian Angels, Letter from Reverend W. Eugene Bolin, Chairperson, Friends of Clinton-South, to Edward Koch, July 15, 1988. Edward I. Koch Collection, Department Correspondence Series, Box \#0000087, Folder \#08: City Hall Staff, Laguardia and Wagner Archives. 
174 "Crack Hits Midtown With a Bang," New York Newsday, July 18, 1988. Viewed online at http://west45thstreetblockassociation.org/wpcontent/uploads/1988/06/88 Dnews_Angels-Cops patrol.pdf

175 "Urban Horror," letter to the editor from David F. Robinson, New York Post, July 13, 1988, 22.

176 “The New Show off Broadway: $46^{\text {th }}$ Street: The 'Angels' are Drawing Reporters, and Tourists, Too," New York Times, June 15, 1988, B1.

177 "Guardian Angels Seek Good Old Days," 4.

${ }^{178}$ Ibid.

179 "Crack Hits Midtown With a Bang."

${ }^{180}$ Interview with Illya Lichtenberg, April 7, 2014.

${ }^{181}$ Interview with Curtis Sliwa, January 9, 2014; Sagalyn, Times Square Roulette, 320322.

182 “Of Guardian Angels, Drug Crime, and Life in NY," Philadelphia Inquirer, June 16, 1988, viewed online at http://articles.philly.com/1988-06-16/news/26264876_1_curtissliwa-guardian-angels-drug-dealers

${ }^{183}$ Marshall Berman, "Ruins and Reforms: New York Yesterday and Today," Dissent 34 (Fall, 1987), 427. The $42^{\text {nd }}$ Development Corporation anticipated that "Both the design of the redevelopment and its generation of a new group of users will discourage the type of loitering that goes on today... The new merchants... will have a strong incentive to defend this space in order to protect their investment... [and new consumers] will establish a presence and territorial claim of their own." Draft Environmental Impact Statement, The $42^{\text {nd }}$ Street Development Project, New York, 1984, 2-122.

184 “The Vigilante," Amsterdam News, January 19, 1985, 12; "Leaders on Goetz Case: 'We are sitting ducks?'” Amsterdam News, June 20, 1987, 1.

185 “Taste of White Justice in New York,” Amsterdam News, June 27, 1987, 15.

186 "Goetz' case called reflection of Reagan's vision of America," Amsterdam News, October 24, 1987, 4.

${ }^{187}$ Interview with Arnaldo Salinas, January 5, 2014.

188 “"Go Free? No thanks,"” New York Post, January 5, 1985, 3; “The Vigilante Mystique," The Washington Post, January 17, 1985, B1; "The Nightmare: Terror reigns in Nation's Streets," Beaver County Times, January 18, 1985, 1. 
189 “Guardian Angels Hold Vigil," Ellensburg Daily Record, December 23, 1985, viewed online at Google News.

${ }^{190}$ Doug Linder, "The Trial of Bernhard Goetz," viewed online at http://law2.umkc.edu/faculty/projects/ftrials/goetz/goetzaccount.html.

${ }^{191}$ George P. Fletcher, A Crime of Self-Defense: Bernhard Goetz and the Law on Trial (Chicago: University of Chicago Press, 1990), 129.

192 Another protestor said that "Sliwa is brainwashing and misleading our black youth." “Angry Blacks Chase Away Sliwa," Amsterdam News, June 27, 1987, 1.

193 “Guardian Angels Stress Patrol on Streets.” New York Times, December 11, 1987, B1. 194 “The Vigilante,” 12.

195 "Looking for Trouble: Lisa Sliwa and the Angels Find it in Boston," Boston Phoenix, September 4, 1984, viewed online at http://thephoenix.com/boston/news/89302-lookingfor-trouble/

${ }^{196}$ Ibid.

${ }^{197}$ Chronopoulos, Spatial Regulation in New York City, 181.

198 “Giuliani's Way: Sliwa's racial slurs make him a curious choice," Amsterdam News, August 28, 1997, 6.

${ }^{199}$ Simon, Governing Through Crime.

${ }^{200}$ On the role of liberals in the advance of law-and-order policies and the carceral state, see Naomi Murakawa, The First Civil Right.

${ }^{201}$ Lisa L. Miller, "The Invisible Black Victim: How American Federalism Perpetuates Racial Inequality in Criminal Justice," Law and Society Review 44 (September/December 2010): 809; Forman, "Racial Critiques of Mass Incarceration," 115.

${ }^{202}$ Interview with Arnaldo Salinas, January 5, 2014.

${ }^{203}$ Interview with "Diamond," January 10, 2014. 
The Rebuilding of the South Bronx after the Fiscal Crisis

Themis Chronopoulos

\begin{abstract}
This article explores the rebuilding of the South Bronx from 1977 to 2003 . This rebuilding represents an important public policy accomplishment, since the South Bronx was one of the most physically devastated areas in the United States. In terms of economic policy, the rebuilding of the South Bronx defies linear narratives. One the one hand, public-private partnerships, which represent some of the most important features of urban neoliberalism were used heavily in the revitalization of the South Bronx. Community organizations that had been rebuilding areas in the South Bronx in the 1970s and the 1980s were required to conform to the requirements of the market, if they were to continue participating in urban development. On the other hand, the building of housing for low- and moderate-income people is not exactly a neoliberal economic policy, since these housing units were built with public subsidies and regulated by government agencies. In its insistence to rebuild the South Bronx as well as other physically devastated areas, the city government of New York became involved in creative financing by incorporating non-government organizations that were ran by accomplished businesspeople but remained non-profit. And whatever the original intentions of city administrations in building and preserving affordable housing in the South Bronx may have been, the accommodation of so many low income people performing low-paying but essential jobs, has contributed to the making of a more vibrant urban economy, even if these same people are not necessarily the ones benefitting from New York's economic dynamism.
\end{abstract}

Acknowledgments: A version of this article was presented at the American History Seminar, Institute of Historical Research, School of Advanced Study, University of London, U.K. I would like to thank Ed Ramsden, Jonathan Bell, Nick Witham, Uta Balbier, Nicholas Grant, and the participants of the seminar for their suggestions. The author is also grateful to Jonathan Soffer for his valuable comments.

Biography: Themis Chronopoulos is a lecturer in American History and Culture at the University of East Anglia in Norwich, United Kingdom. He is the author of Spatial Regulation in New York City: From Urban Renewal to Zero Tolerance (New York: Routledge, 2011). He is currently writing a book titled When the Government Disappears: Inadequate Municipal Service Delivery and the Decline of New York City, 1945-1981.

\title{
Keywords:
}

South Bronx

Affordable Housing

City Rebuilding

New York City

Public-Private Partnerships

Social Inequality

Racial Segregation 
In 1973, New York Times journalist Martin Tolchin characterized the South Bronx as "Dresden after the war," "a jungle stalked by fear, seized by rage," "a foreign country where fear is the overriding emotion in a landscape of despair" and a place that is "violent, drugged, burned out, graffiti splattered and abandoned." Throughout the decade, television crews, film makers, and journalists, from the United States and around the world, reinforced these depictions with visual representations of burned-out buildings, shabby streets, sidewalks with overgrown grass, empty lots filled with garbage, disemboweled fire hydrants, crime stories, and suffering residents. ${ }^{2}$ While many of these reports and images focused on the negative and the spectacular, the South Bronx was indeed a distressed urban area. Between 1970 and 1975 the South Bronx lost approximately 43,000 housing units. This housing loss continued unabated with about 7,000 fires erupting in the South Bronx between 1975 and 1977. By 1977 there were more than 3,000 lots and buildings that were considered vacant and covered more than 500 acres. There were also more than 6,900 residential parcels that owed taxes for at least one year and would eventually be subject to municipal takeover (Figure 1). In the 1970s the South Bronx lost 309,471 residents out of 772,589 (Figure 2$)^{3}$

About forty years later, it is difficult to imagine such depictions and figures referring to the Bronx. What was known as the South Bronx has been rebuilt and no one questions the viability of its future. Empty lots and damaged housing are not common. The sound of sirens coming from fire trucks driving up and down major avenues is unusual. So are fires. The population of the South Bronx is growing rather than shrinking. The commercial districts, public parks, neighborhood sidewalks, and public squares of the South Bronx are vibrant while the crime rate is lower than that of many major cities in the United States. ${ }^{4}$

This article examines the rebuilding of the South Bronx from 1977 to 2013. This rebuilding included policies and actions by both the city and federal governments and involved the building or rehabilitation of housing and a liberalization of the flow of immigration after 1965. To be sure these policies, which reinforced each other, were not exactly coordinated. Still, the rebuilding of the South Bronx is a major accomplishment of public policy, the kind that can function as an example to areas still afflicted by urban decline. At the same time, as many other major public policies, the rebuilding of the South Bronx had its advantages and disadvantages. On the one hand, the new housing did not eliminate homelessness, did not accommodate the poorest of the poor, and sometimes required tenant incomes that were higher than those prevailing in the South Bronx. Moreover, the affordable housing subsidies used were not permanent and their renewal required substantial amounts of money to be spent in the 2000 s. On the other hand, thousands of housing units were rehabilitated and thousands more were newly built. The South Bronx became a magnet for working class people, mostly immigrants, who were accommodated by a rebuilt infrastructure and a growing housing market that was affordable. In turn these working class populations fueled the economic growth that New York City has been experiencing, even if they were usually not the prime beneficiaries of this growth. In other words, while this rebuilding policy had its limits, it provided some affordable housing to a working class population necessary for the viability of an urban economy. 


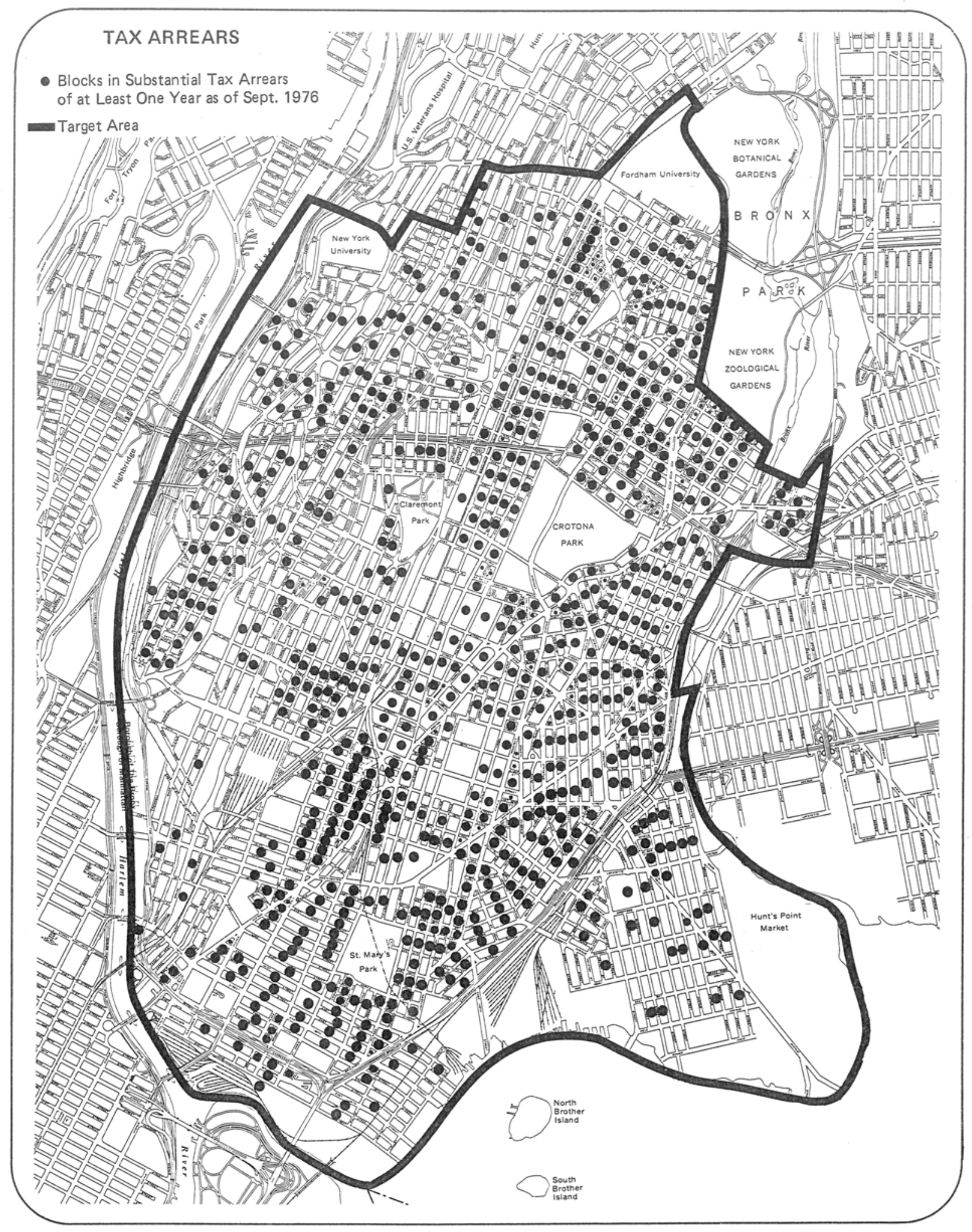

Figure 1. Map of the South Bronx with blocks in substantial tax arrears as of September 1976. The dots represent entire blocks and not individual properties. Source: City of New York, Summary: The South Bronx: A Plan for Revitalization (New York: The City, 1977), 44. 


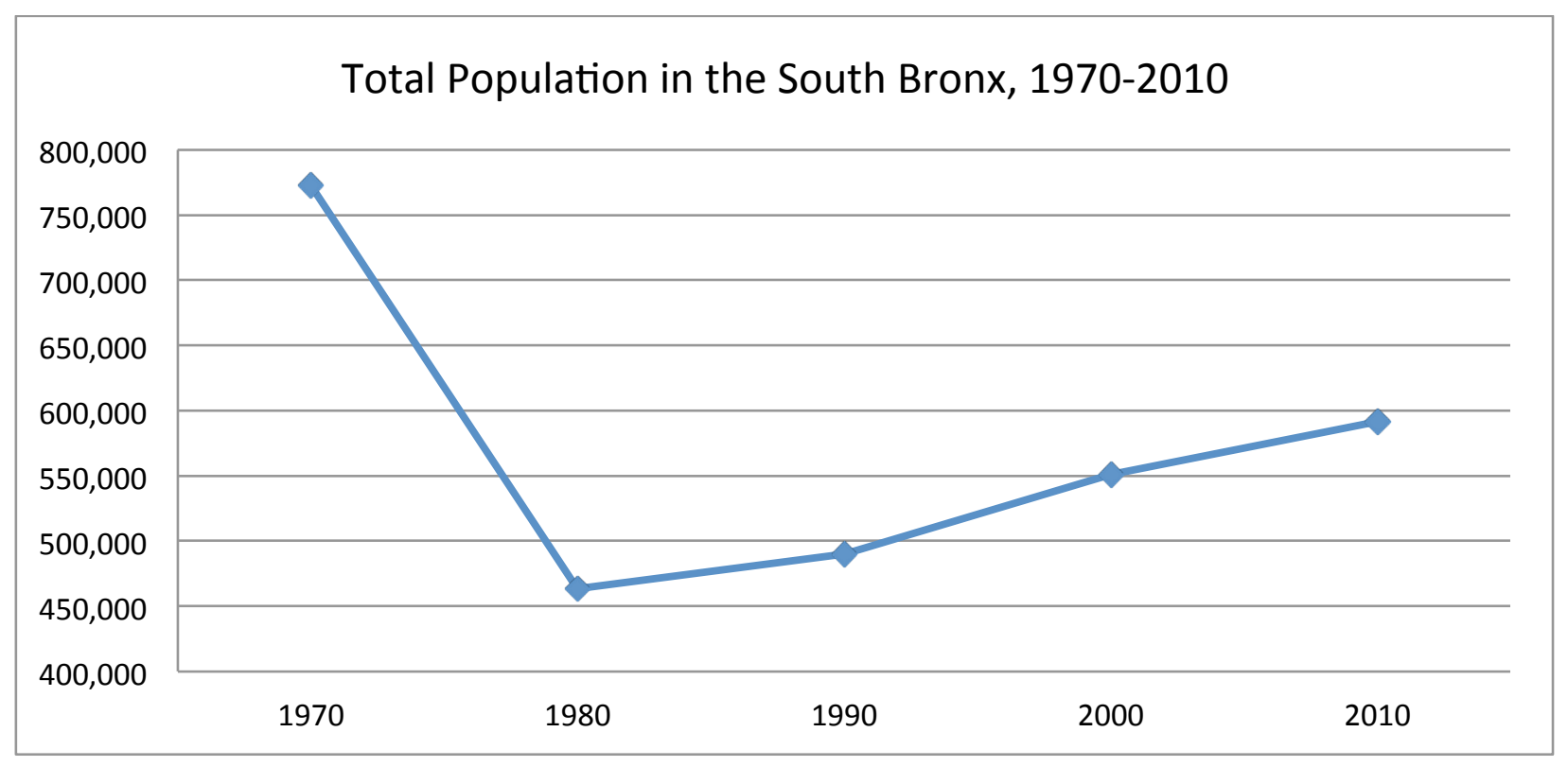

Figure 2. Total population in the South Bronx, 1970-2010. Source: U.S. Census Bureau surveys, 1970-2010.

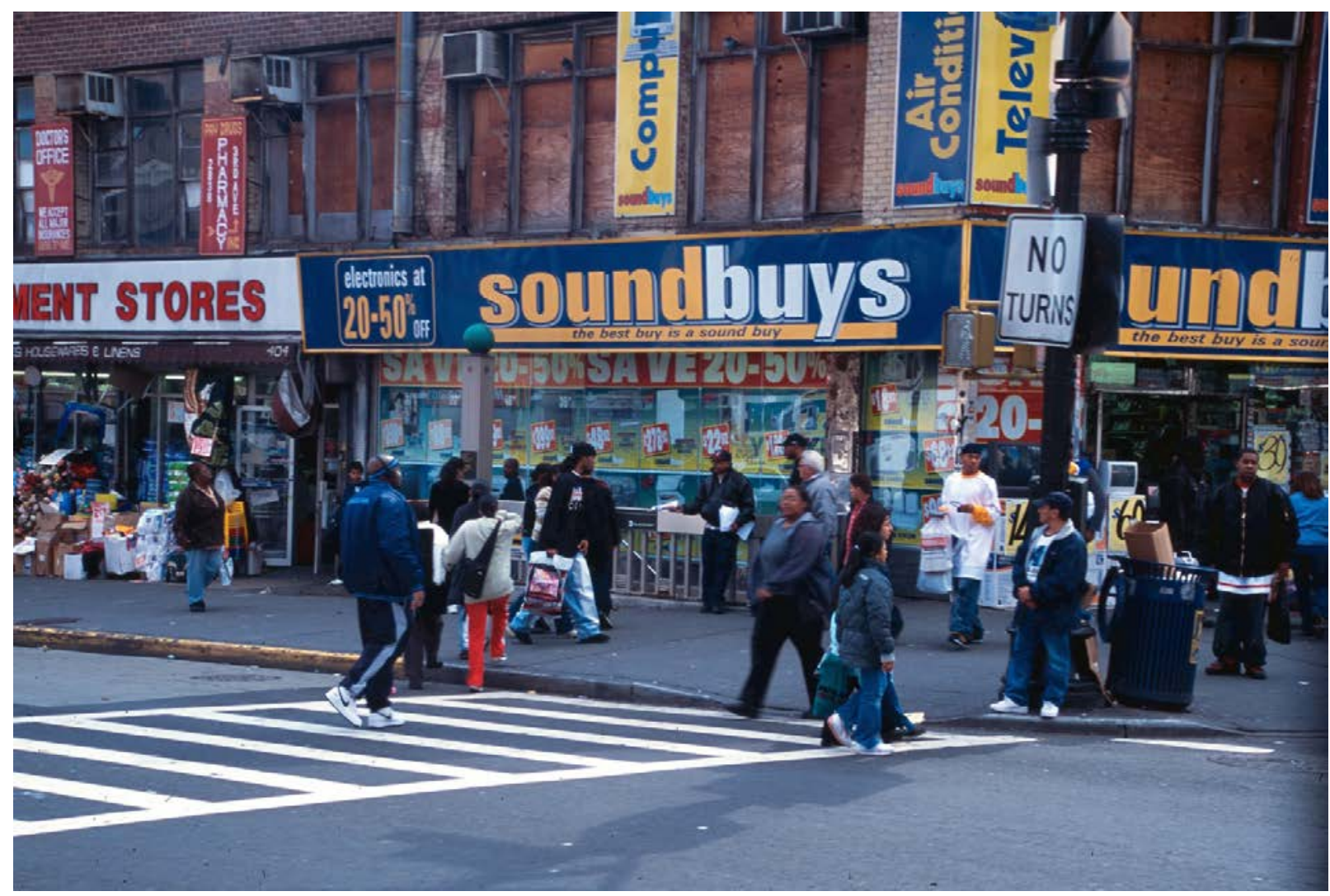

Figure 3. An image of the Hub, a commercial district in the Melrose-Mott Haven areas of the Bronx. Source: Photo taken by the author in 2004. 


\section{Efforts to Rebuild the South Bronx, 1977-1985}

In February of 1976, Roger Starr, administrator of Housing and Development, called for the systematic withdrawal of the city government from areas such as the South Bronx and Brownsville suffering from extreme population decline and a reduction in their housing stock. He called his strategy planned shrinkage and urged the mass resettlement of the remaining residents of these areas to other neighborhoods. Starr justified his recommendation by saying that planned shrinkage would make the fiscal crisis less painful to middle class New Yorkers, allowing the city government to concentrate in neighborhoods that had a viable future. ${ }^{5}$

Starr was influenced by trends, which showed that the South Bronx was rapidly declining. Indeed in the 1970s the South Bronx lost 36 percent of its housing stock (Figure 4) and 40 percent of its population (Figure 2). This meant that one in three housing units was damaged or abandoned. Overall more than 90,000 housing units were no longer officially occupied. Vacant buildings, deserted blocks, shabby streets, and large swaths of empty land dominated the landscape of the South Bronx. This decline began before the fiscal crisis, though the trend of housing and population loss continued into the $1980 \mathrm{~s}^{6}$

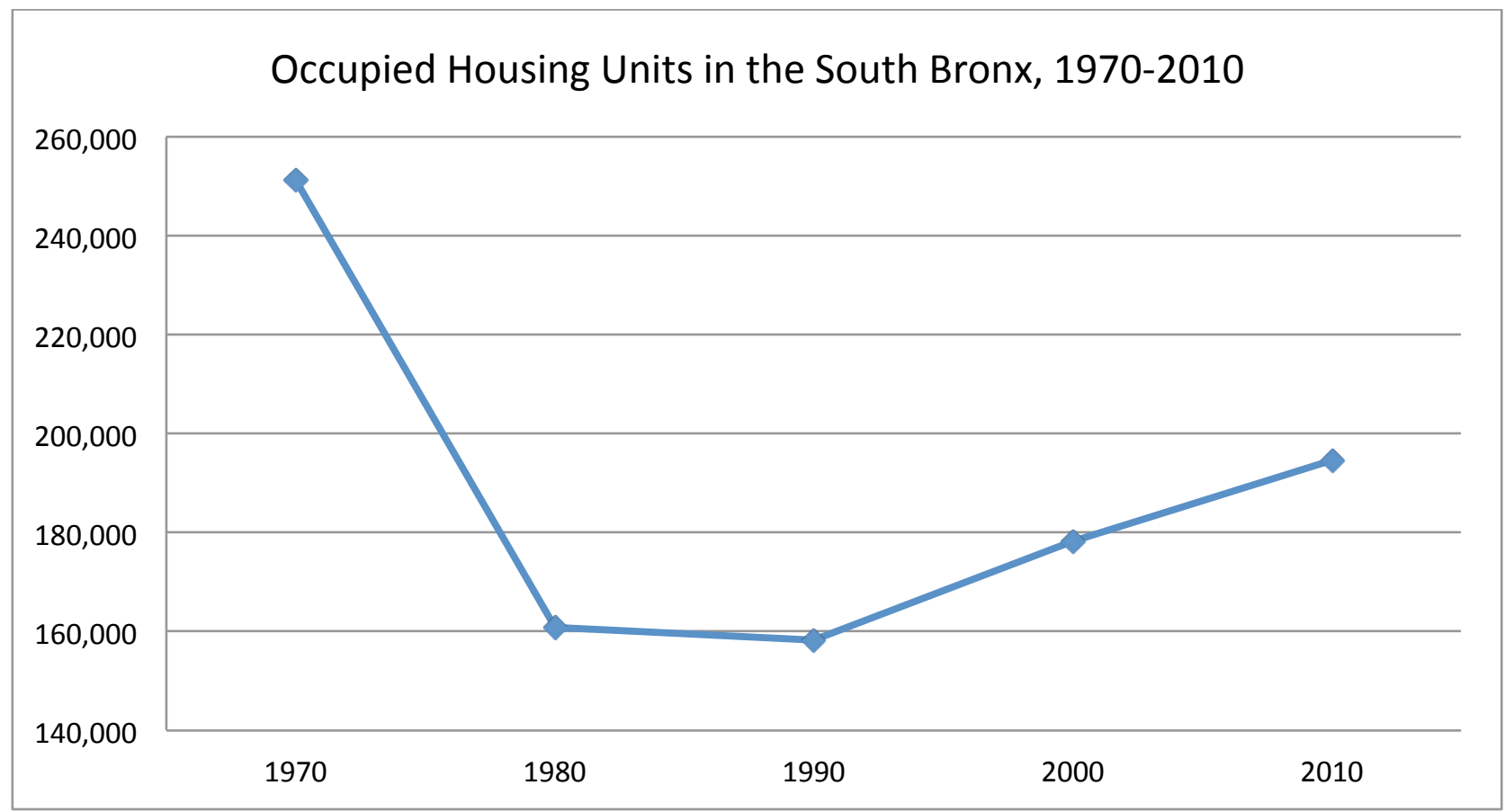

Figure 4. Occupied housing units in the South Bronx, 1970-2010. Source: U.S. Census Bureau surveys, 1970-2010.

The fiscal crisis was precipitated in 1975 when financial institutions refused to buy shortterm New York City bonds, leaving the city short of cash to cover its expenses. New York avoided filing for bankruptcy after the federal and state governments agreed to provide loans and other assistance while the state began to oversee city finances, threatening to intervene if unorthodox financial practices reemerged. In order to deal with the financial crisis, the city government laid off public employees, reduced the provision of municipal services, and abandoned many of its capital projects such as the building of new housing. City budgets stopped growing during the Abraham D. Beame administration (1974-1977) and even declined between 
1978 and 1981 under Mayor Edward I. Koch (1978-1989) (Figure 5). ${ }^{7}$

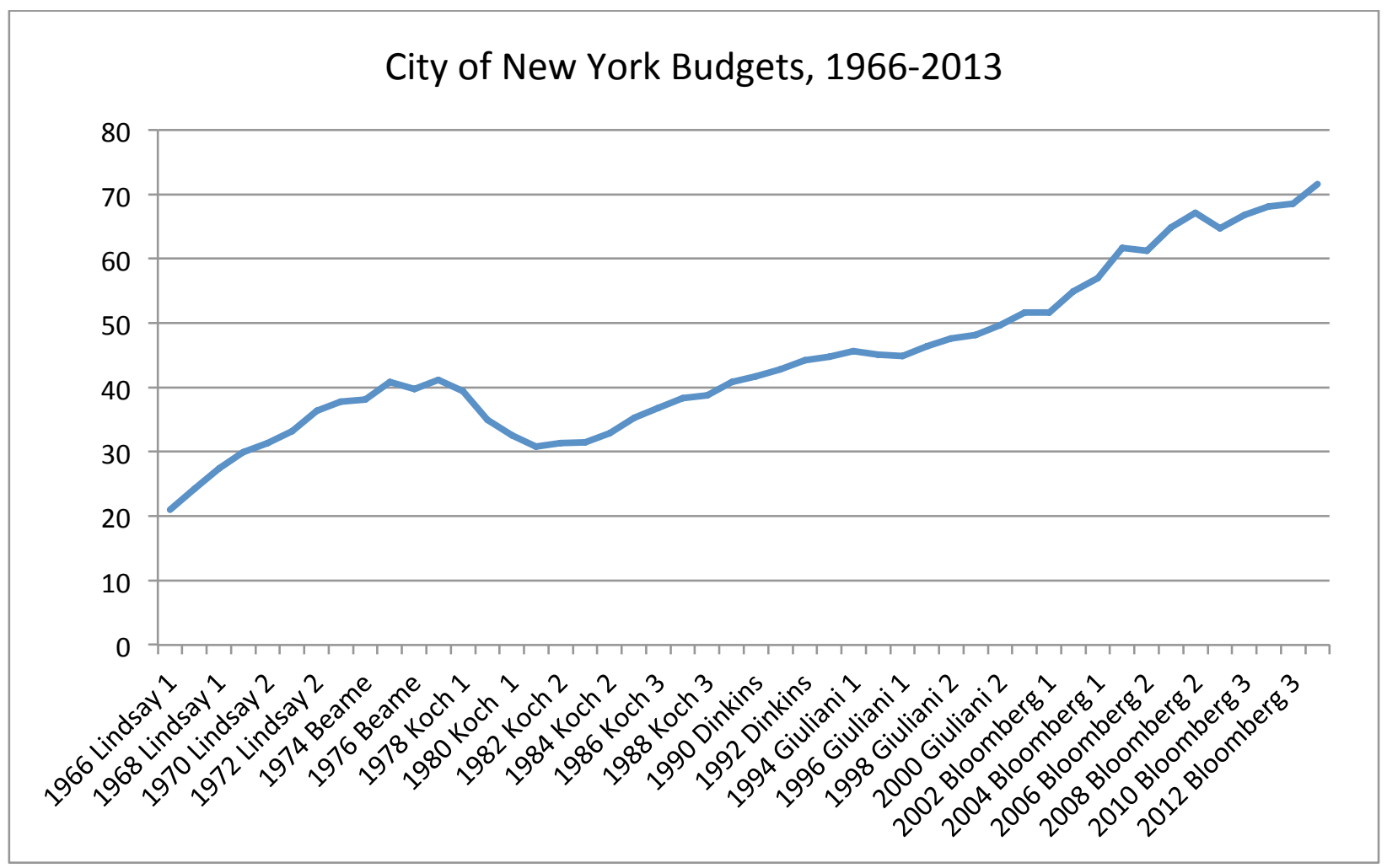

Figure 5. City of New York budgets by administration, 1966-2013. Using GDP deflator these figures are adjusted to 2013 constant dollars. In 1966, the first year of Mayor John V. Lindsay, the annual budget was a bit more than $\$ 20$ billion (almost $\$ 3.8$ billion in nominal dollars). In 2013, the final year of Mayor Michael R. Bloomberg, the budget surpassed the $\$ 70$ billion mark. Generally, as the economy grew so did the budget. Source: Annual Report of the Comptroller of the City of New York, 1966-1979 and the Independent Budget Office of the City of New York, Agency Expenditures, 1980-2014 (New York: The Office, 2015).

While numerous public officials including Mayor Beame denounced Starr's planned shrinkage suggestion as inhumane and impractical, these ideas of abandoning the South Bronx were not unusual; they represented the dividing line between two conflicting visions of New York's future. In the 1970s, the population of New York City declined for the first time in its history. The city lost 823,212 people amounting to $10.4 \%$ of its population (Figure 6 ). Some members of city's elite wanted to hasten this contraction, so that the city government could allocate its limited resources in viable areas. Felix G. Rohatyn - a banker who was heading the Municipal Assistance Corporation (MAC), which during the fiscal crisis was authorized by the state to sell bonds to meet the borrowing costs of the city - sided with Starr and argued that blighted areas of New York should be bulldozed and rebuilt as industrial areas. In 1978, U.S. Senator from New York Daniel Patrick Moynihan opposed the reconstruction of parts of the South Bronx with federal funds stating: "People in the South Bronx don't want housing or they wouldn't burn it down. It's fairly clear that housing is not the problem in the South Bronx." 8 
Moynihan subscribed to the idea that residents of areas like the South Bronx while pursuing their own selfish interests were responsible for false fire alarms, arson, and other forms of housing destruction. Though not shared by Koch, these conclusions made large-scale plans to rebuild the South Bronx more difficult to justify. ${ }^{9}$

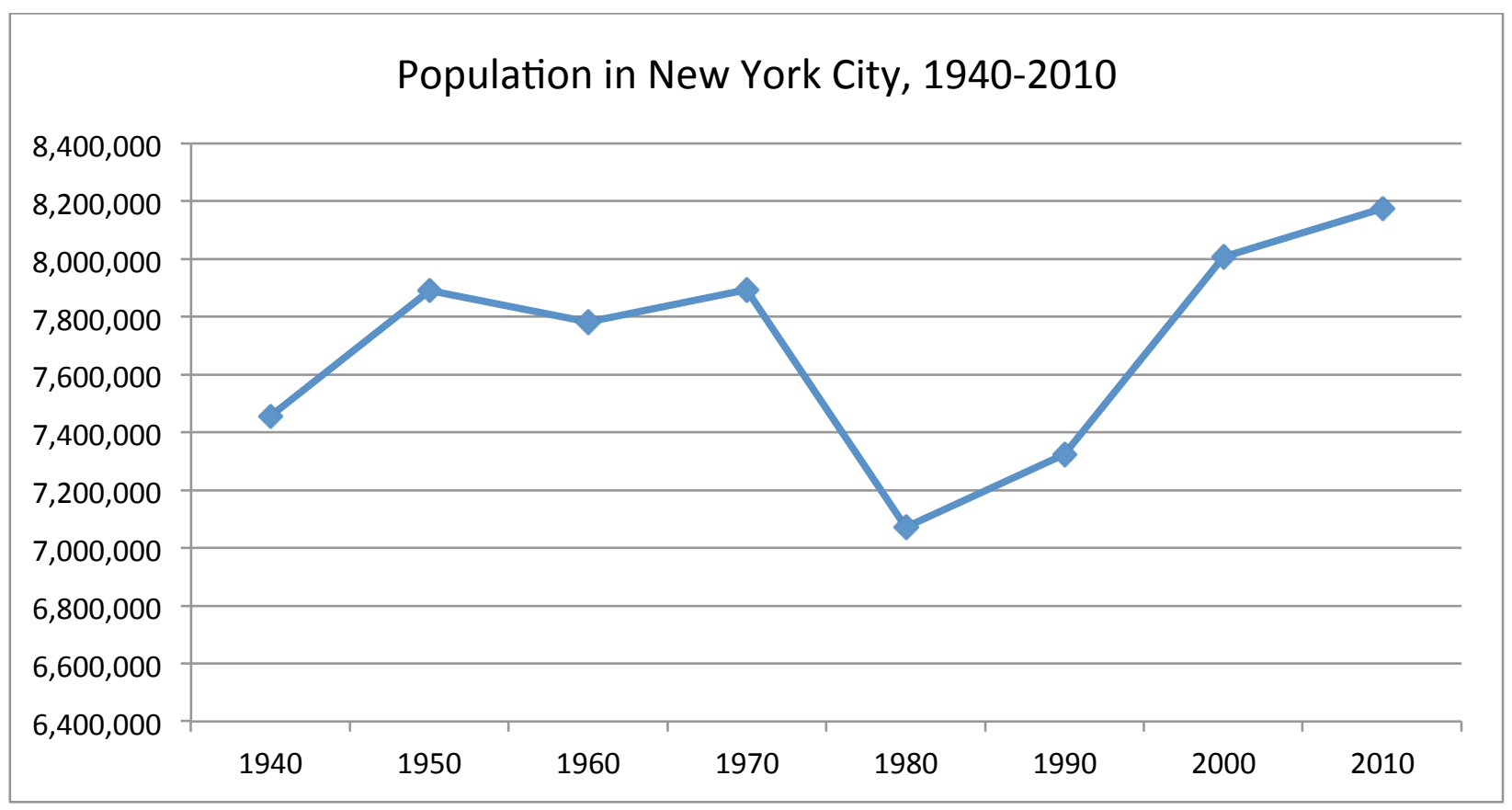

Figure 6. Population in New York City, 1940-2010. Source: U.S. Census Bureau surveys, 19702010 .

The only large-scale housing project to be completed during this period involved the Morrisania Air Rights Houses. This project was planned in the early 1970s when the city government secured funding from the Department of Housing and Urban Development (HUD) for its construction. However, it was not possible to find a developer willing to build the project for the amount appropriated. This changed in 1977 by which time construction costs had dropped because of the economic slowdown. It was constructed in the 1977-1980 period. Morrisania Air Rights was built on a platform on top of the Penn Central railroad. It comprised of three buildings that covered the length of five blocks between East 158th and East 163rd Streets west of Park Avenue and contained 843 low-income housing units. ${ }^{10}$

The Morrisania Air Rights project showed a new determination by city officials to revitalize the South Bronx. In the spring of 1977, Bronx Borough president Robert Abrams and chairman of the City Planning Commission Victor Marrero prepared a redevelopment proposal and sent it to the secretary of HUD Patricia Harris. While the proposal and the discussions that followed went nowhere, President Jimmy Carter and Harris visited the South Bronx that October. Carter requested a new rebuilding plan. Recycling older proposals, the Beame administration sent a plan in the end of 1977. It included a five-year $\$ 870$ million rebuilding, employment, and commercial development plan with the federal government paying something between $\$ 658$ and $\$ 738$ million. Given that Beame had been defeated in his reelection bid that September, it would be up to the incoming Mayor Koch to implement this rebuilding. ${ }^{11}$ 
In the first three months of 1978, the Koch administration made its own South Bronx revitalization plan that would cost more than $\$ 1$ billion (revised later to $\$ 1.5$ billion). Koch appointed Lloyd M. Kaplan as the project's coordinator. However, Herman Badillo one of Koch's deputy mayors took charge of the project. Badillo who had served as housing commissioner (1962-1965), Bronx Borough president (1966-1969), and congressman (19711977), resigned his U.S. House of Representatives position in order to become deputy mayor. He met with Carter and argued that the rebuilding of devastated low income neighborhoods across the United States required the construction of low-density housing for homeowners. Given that high density housing occupied by renters was viewed as a cause of the South Bronx's decline, this proposal sought to address the problem by completely remaking the built environment and tenancy of the area. Anticipating that most of the people willing to live in the South Bronx could not afford to pay mortgages and large down payments, Badillo recommended state subsidies. He insisted that the South Bronx only needed new housing and tenants, since it already had the water systems, sewers, subway stations, schools, and other infrastructure necessary for neighborhoods to function. The federal government pledged a $\$ 56.5$ million first installment in April of 1978, though most of the money was earmarked for economic development. The city insisted in its housing plan and Badillo recruited Edward J. Logue to be the executive director of the South Bronx Development Organization (SBDO). Logue had previously been in charge of urban renewal in New Haven (1954-1960) and Boston (1961-1967). He went on to head New York's Urban Development Corporation (UDC) between 1968 and 1975. Although the UDC, a public benefit corporation that could issue moral obligation bonds, almost defaulted in its debt in 1975 and was bailed out by the state, thousands of housing units were built in various parts of the state including the city under Logue's leadership. Logue was viewed as someone with the ability to develop housing for low-, moderate-, and middle-income families that could be selfsustainable. The SBDO was also involved in economic development by attracting industry to abandoned industrial areas. $^{12}$

Badillo's rebuilding plans failed. He selected the area around Charlotte Street, which had been toured by Carter, as the first redevelopment site and proposed the building of a 732-unit, low-rise cooperative with a cost of $\$ 32$ million. Robert F. Wagner Jr. who had become chair of the City Planning Commission declared his opposition to the project, arguing that it would be isolated from sound neighborhoods. Wagner favored the expansion of viable neighborhoods rather than building in the middle of nowhere. He came around to support the project only after pressure by Koch who promised to also rebuild the area around Charlotte Street, so that a continuous neighborhood could be formed. The members of the Board of Estimate expressed their reservations as well, but ended up approving the project by a vote of 10-1 in November of 1978. However, the project remained controversial. In February of 1979, the Board of Estimate met again for what appeared to be a procedural vote over the closure of some streets in order to create a superblock in the Charlotte Street development area. In this meeting, the Board of Estimate voted against the street modification by 7-4 and effectively killed the project. The members of the Board of Estimate turned around for various reasons including political ones. However, they also worried that the Koch administration was placing too much emphasis on the South Bronx at the expense of other devastated areas in their boroughs. Portions of Brooklyn and Queens were experiencing their own severe urban decline problems that were worsening because of the city's reduction in the funding of municipal services, infrastructural maintenance, and capital projects. $^{13}$

This vote was the catalyst of a number of developments that defined the rebuilding of the 
South Bronx until 1985. Koch angrily denounced the opponents of Charlotte Street development and cancelled the entire seven-year \$1.5 billion South Bronx rebuilding plan. Badillo removed himself from the South Bronx effort and resigned as deputy mayor a few months later. In August of 1979, the Koch administration announced a new \$375 million rebuilding plan, which was characterized by Badillo as "the most cowardly kind of retreat a Mayor could indulge in." editors of the New York Times praised the new plans for the South Bronx, which were drafted with Logue's input: "Mr. Logue also urges plans that would consolidate rather than expand the borough's population and economic activity; it would be futile to rebuild for a population as large as that of the 1940's." ${ }^{\prime 15}$ Logue understood that even the commitment of $\$ 375$ million by the city was questionable and curtailed his plans. After all, his office had been operating with $\$ 4$ million each year since 1978. The appropriation of an amount higher than this for the following twelve months appeared unlikely. To be sure, there were other funds by other agencies that were earmarked for the South Bronx, even if those were also meager. ${ }^{16}$

Logue decided to abandon top-down development that characterized Badillo's approach and pursue projects with a number of community development corporations (CDCs). CDCs emerged in the late 1960s after an amendment to the Economic Opportunity Act of 1964 encouraged the collaboration of the private sector with the government and communities in order to tackle the problems of urban poverty. It was during this period that Father Louis Gigante's South East Bronx Community Organization (SEBCO) operating mostly in Hunts Point was established, so that it could participate in the Model Cities program. The emphasis of these early CDCs was economic development with housing being only one aspect of their activities. The restructuring of federal housing policy under Richard Nixon shifted the CDCs' focus to housing. In 1974, the Community Services Act formally recognized CDCs and provided them with Community Development Block Grants primarily used for capital investments. In 1978, the Community Reinvestment Act made it easier for low income communities to access capital from financial lenders and this further encouraged housing development by CDCs. Between 1977 and 1981, SEBCO in partnership with developer Jerome Chatsky developed twenty-six buildings comprising of 1,070 housing units. Other CDCs in the South Bronx included the Bronx Frontier Development Corporation, Banana Kelly, and the People's Development Corporation. They did not have as many projects as SEBCO, but they were determined to make a difference in the blocks that they covered. These organizations operated in their own neighborhoods, used sweat equity, and received subsidies from the city, state, and federal governments. They collaborated with private developers and aimed at the rehabilitation (and sometimes new building) of wellmanaged, self-sustainable, and adequately-maintained buildings. CDCs took the lead in developing the South Bronx during this period sometimes cooperating with Logue and the city government and sometimes pursuing their own projects in partnership with the federal government. However, after a substantial influx of federal money in 1980 when Carter was running for reelection, funding declined. ${ }^{17}$

Lacking the funds to substantially rebuild the South Bronx, in the early 1980s the city government in alliance with foundations and CDCs resorted to image-making, so that the area would at least appear attractive. The Bronx Land Reclamation Project, the first far-reaching effort to regenerate the image of the South Bronx, was led by the Open Space Task Force and Logue's SBDO. Organizations such as the Rockefeller Brothers Foundation, the J. M. Kaplan Fund, the Ford Foundation, and the Fund for the City of New York offered grants to CDCs such as Banana Kelly, the Bronx Frontier Development Corporation, and the People's Development Corporation to create community gardens, urban farms, and green playgrounds. In terms of land 
coverage, the most extensive portion of the program included the planting of wildflowers in hundreds of acres of desolate neighborhoods. The CDCs and their funders viewed land reclamation as a temporary measure. They thought that the community gardens, urban farms, and flower gardens would eventually give way to redevelopment. The second important imagemaking effort involved color vinyl decals that covered bricked up windows with pictures of curtains, shutters, flowerpots, and venetian blinds (Figure 7). Though a citywide program, the beautification of buildings visible from the Cross-Bronx Expressway received much publicity by city agencies. Robert Jacobson, director of the Bronx office of the City Planning Commission, argued that "the image that the Bronx projects - and projects to potential investors - is the image you see from that expressway, and our goal is to soften that image so people will be willing to invest." 18 The window-dressing project was ridiculed by the mass media, and Koch found himself writing a letter to the New York Times defending the project:

We are simply trying to face the reality that New York cannot rehabilitate structurally sound buildings or demolish structurally unsound buildings as fast as we would like. We want to use decals as a way to make buildings waiting for either demolition or rehabilitation more attractive to communities and less attractive to vandals in the interim. ${ }^{19}$

For Koch, image-making did not signify the further abandonment of the South Bronx by the city government, but an effort to improve its appearance until more money became available, though few shared his optimism that he would be able to find the funding to fix a broken borough. ${ }^{20}$

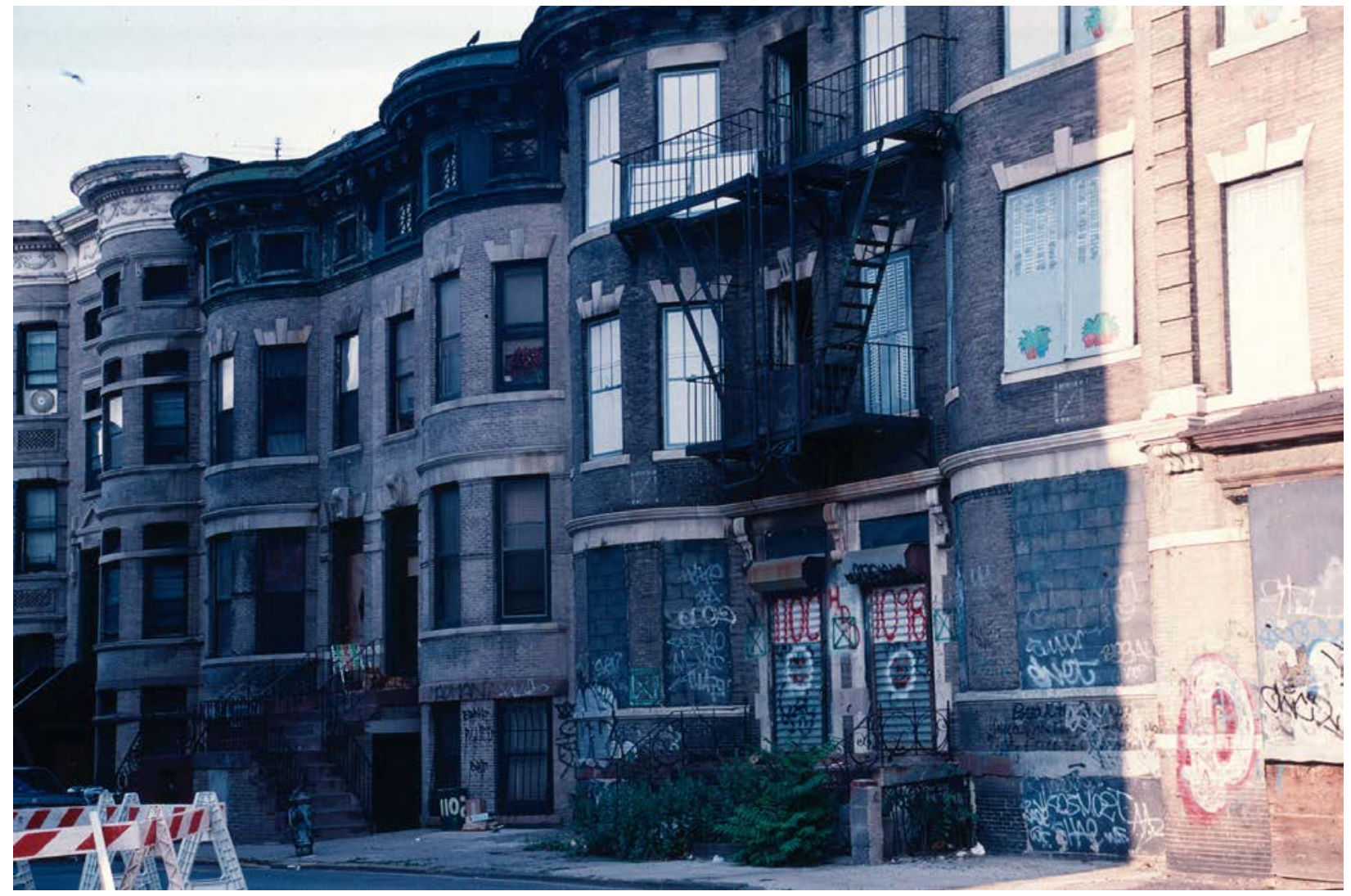

Figure 7. Building in the South Bronx with vinyl decals. Source: Photo taken by the author in 1997. 
Logue was interested in building housing more than in image-making projects and decided that he could activate the revival of the South Bronx by developing and marketing single-family suburban type houses with white picket fences. The SBDO had already been pursuing low-rise, home-ownership projects in a few select areas, subscribing to the idea that the South Bronx had too many rental properties and that this contributed to its dramatic decline. Logue made his priority land coverage rather than housing density, though the existing developments were not getting much publicity. He felt that the controversial Charlotte Street area that had been visited by various politicians and television crews, promised to change this, especially if the kind of housing built there resembled the suburban housing of Long Island and Westchester County. Logue proposed to buy houses manufactured elsewhere and ship them to the South Bronx; SBDO received about \$300,000 from the Local Initiatives Support Corporation (LISC) - a philanthropic organization founded by the Ford Foundation - to build a couple of houses as models. Logue also approached the Mid-Bronx Desperadoes Housing Corporation (MBD) to become partners of the project. The MBD was formed in the mid-1970s by a number of churches, tenants' associations, and other civic organizations. Father Gigante advised the group at various stages. The MBD used Gigante's developer Chatsky to rehabilitate Vyse Avenue between East 173nd and 174th Streets. After Vyse Avenue, Logue partnered with the MBD because Charlotte Street was their territory. With the advice of the MBD, Logue hired members of the Nighthawks gang to guard the Charlotte Street development area, so that the housing models would not be vandalized. Eventually, about ninety ranch houses were built in the area. The project received much publicity, even when only two housing models occupied the site. However, this project led to Logue's demise as developer. ${ }^{21}$

Logue had been a great builder but not a great administrator. When funding was plentiful as in most of his previous jobs, Logue could complete even the most difficult projects without minding the costs. He usually focused on the big picture, allowing others in his organization to deal with finance, management, and day-to-day operations. Lack of money in the South Bronx forced Logue to become more of a manager and to operate in a complicated environment of various actors pursuing their own interests. In Charlotte Gardens, Logue hired an inefficient contractor who caused long delays. Logue replaced the contractor, but this resulted to cost overruns. Making the houses elsewhere and shipping them to the Bronx was not as cheap as Logue originally thought contributing to even higher costs. In the end, it took three builders to finish the Charlotte Gardens houses. When it appeared that the government might cancel the remainder of the program, Logue ordered the construction of the concrete foundations for eighty houses, which cracked because of the cold winter temperatures. And such problems were not exclusive to Charlotte Gardens. SBDO was in charge of another project on East 169th Street in Morrisania. Eighty-three families put money down in 1982 to buy rowhouses. However, more than two years later, no houses were built other than the original two models while the developer had spent all the appropriated money and Chemical Bank was auditing the project before deciding to lend more. Logue found this to be unusual and said that "somebody owes somebody $\$ 3$ million, and there are 81 homeowners hanging by their thumbs." 22 In the spring of 1984, the federal government refused to automatically renew SBDO's funding as in previous years. Logue resigned from his post a few months later and the MBD took over the Charlotte Gardens project. $^{23}$

In his efforts to jumpstart urban development in the South Bronx, Logue embraced suburban-style homeownership in an area that had traditionally been renter-occupied and high density. Logue claimed that he got the idea of building single-family homes in Charlotte Gardens 
after observing the admirable behavior of homeowners who in the midst of deplorable conditions in the South Bronx took care of their houses and their neighborhoods. ${ }^{24}$

As Benjamin Holzman has demonstrated in his piece in this section, the supposed superiority of owners over renters as caretakers of property was an article of faith among many politicians and realtors. In the South Bronx, Logue's claim was curious given that 95.7 percent of housing in 1980 was occupied by renters. ${ }^{25}$ If anything, they deserved credit for holding neighborhoods together. However, the assumption that homeowners functioned as anchors that stabilized neighborhoods persisted, even when it became obvious that this was not realistic in the South Bronx. This assumption is part of homeownership ideology in the United States under which homeowners are viewed as better citizens taking care of their community. ${ }^{26}$

Regardless, Logue's approach had been admirable, though in the aggregate the South Bronx continued to lose housing units in the first half of the 1980s. Anyone of his stature would have resigned in 1979 when it became clear that the grand-scale plans to rebuild the South Bronx were discontinued. But Logue was optimistic; he felt that he could make a difference and that eventually his office's successes would convince government agencies to rebuild the South Bronx. In fact, Koch and his close aides began to think of a more ambitious housing plan that would require large capital expenditures partly because Logue had shown that the possibility of revival existed and partly because low income areas in the city continued to lose housing units and this was interfering both with economic growth and the image of the city.

\section{The Rebuilding of the South Bronx, 1986-2001}

In his 1985 state of the city, Mayor Koch announced that the city government would become more directly involved in the rebuilding of neighborhoods and spend $\$ 4.4$ billion in order to build of rehabilitate 100,000 housing units in five years. A few months later, the administration amended the plan into a ten-year undertaking that would produce 250,000 housing units. In 1989, the plan was amended once more committing $\$ 5.1$ billion and promising the rehabilitation of rebuilding of a total of 252,000 housing units by 1996 . These amendments of the original plan showed the extent to which administration officials were serious about the rebuilding of low income neighborhoods in New York City, given that there is no such thing as a grand-scale urban development plan that is not changed and revised several times. In the end, the completion of this neighborhood rebuilding required the commitment of three administrations. David N. Dinkins defeated Koch in the mayoral election of 1989 and Rudolph Giuliani defeated Dinkins in $1993 .^{27}$

The timing for such an ambitious housing plan was right. After 1981, tax revenues and other income for the city increased while debt service expenditures declined. In the 1982-1984 period budgets stabilized after four years of subsequent and painful declines. Then they began to grow substantially with a 7.1 percent growth in 1985 and another 4.4 percent in 1986 (Figure 5). Moreover, after a successful reorganization of the Fire Department structural fires which had been the cause of much housing destruction declined, reaching a level not seen since the early 1960s (Figure 8). At the same time, affordable housing was becoming more difficult to obtain while thousands of buildings remained damaged. The Koch administration viewed this rebuilding as an economic development project that would improve the image of the city, rebuild neighborhoods, provide affordable housing, and solidify the mayor's reelection chances in 1989 for an unprecedented fourth term. ${ }^{28}$ 


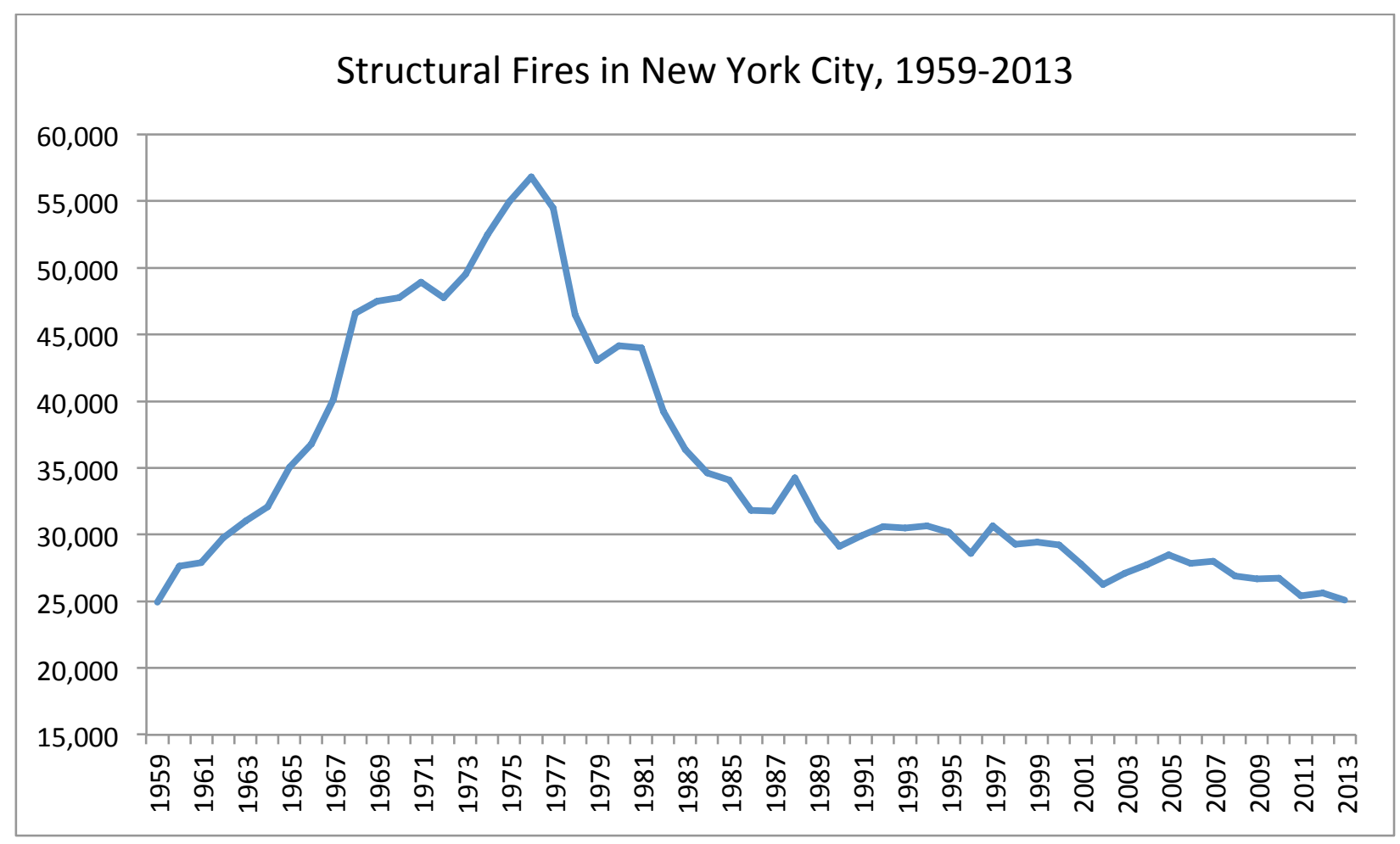

Figure 8. Structural fires in New York City, 1959-2013. While these are citywide figures, the great majority of structural fires erupted in low income areas such as the South Bronx, devastating their built environment. Structural fires involve fires in buildings. They do not include brush fires, automobile fires, transit system fires, or garbage fires. Source: Fire Department Annual Reports and other documents of the City of New York, 1959-2013.

Despite the city's growing economy, the Koch administration wanted to rely on public authorities for the financing of large infrastructural projects including housing, so that the city government would not be burdened with additional debt. This plan did not work out as anticipated. In 1984, the State of New York created the New York City Municipal Water Finance Authority (MWFA), a public benefit corporation, to finance the capital needs of the water and sewer system of the city. This action freed up hundreds of millions of dollars in the borrowing capacity of the city. Koch lobbied for the creation of more such corporations to repair bridges and build garbage disposal facilities, but the state legislature did not acquiesce. At the same time, city officials expected another public benefit corporation, the New York City Housing Development Corporation (HDC) to market tax-free bonds to finance most of the new housing after an increase in the corporation's borrowing capacity; however, this did not happen at the levels expected. The HDC was founded in 1971 by the state legislature after the City of New York exhausted its constitutional capacity to incur additional debts for housing and urban development. The HDC was viewed as a way to get around this constitutional limitation by selling bonds to private investors without the city being directly responsible for them. Indeed, the HDC sold moral obligation bonds and used the proceeds to make loans to owners of multiple dwellings or to housing companies for the rehabilitation or new construction of rental housing for low-, moderate-, and middle-income people. The federal Tax Reform Act of 1986 eliminated many tax incentives for the production of rental housing and this undermined the Koch 
administration's expectation that the HDC would finance large portions of its housing plan. More than this, a severe economic slowdown in New York City, national economic problems, and the savings and loan crisis, made it more difficult for moral obligation bonds to be issued. As such the HDC's bond issuance declined after 1985 for three subsequent years reaching the low figure of $\$ 11,430,000$ (19,661,523 in 2013 dollars) in 1988. Despite some recovery, the levels of bond issuance remained low at a time that the city was pursuing its ambitious housing plan and reached the figure of $\$ 0$ in 1992 (Figure 9). The city's capital and operational budgets had to pick up the difference in order for the housing plan to continue at the scale originally envisioned. The existence of the MWFA allowed these increased expenditures. ${ }^{29}$

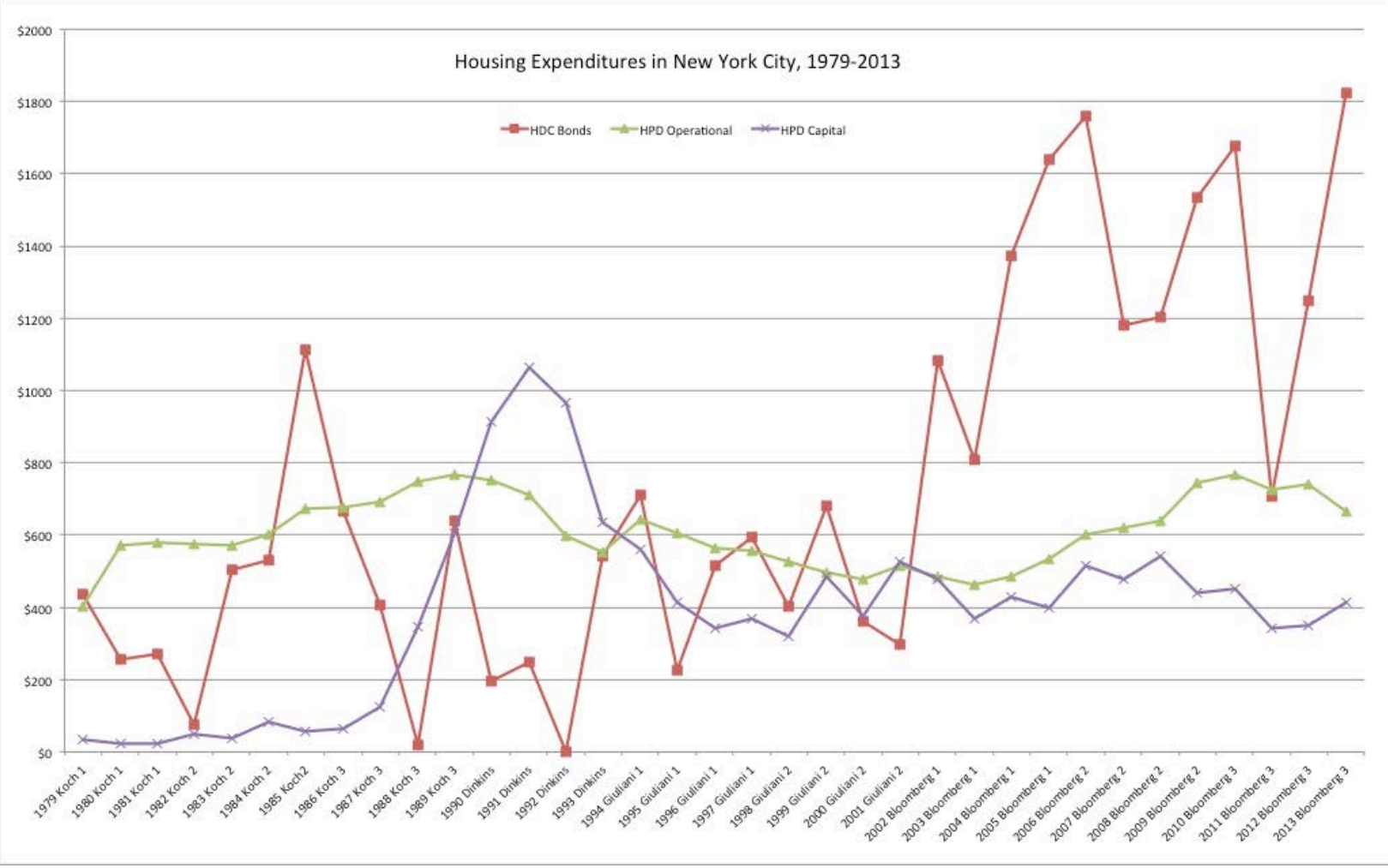

Figure 9. HPD operational and capital expenditures as well as HDC proceeds from the sales of bonds, 1979-2013 in millions of dollars. Using GDP deflator these figures are adjusted to 2013 constant dollars. Source: Annual Report of the Comptroller of the City of New York, 1979, the Independent Budget Office of the City of New York, 1980-2013, and the Annual Report of the HDC, 1979-2013.

The Ten-Year Housing Plan was implemented by the Department of Housing Preservation and Development (HPD). The HPD is a city agency in charge of developing and maintaining affordable housing. ${ }^{30}$ At the time, the agency's operating expenses covered the management of in rem properties (tax-foreclosed buildings taken over by the city), the improvement and maintenance of existing housing, tenant assistance, demolition or seal up of damaged buildings, as well as administrative expenses and personnel salaries. The HPD's capital budget, which was financed through the sale of bonds, covered mostly the gut rehabilitation of existing structures and the building of new ones. The HDC, viewed as a sister organization, was 
closely collaborating with the HPD, providing funds that were entirely raised from non-city sources. However, the Ten-Year plan was mostly financed by HPD's capital budget. Some money also came from the HPD's operating budget. The plan also used federal funds, state funds, cross-subsidies from luxury projects, a contribution from the World Trade Center, and money from the Battery Park City Authority. Whether it was operating or capital funds, the HPD also paid for some of the infrastructural needs of the rebuilt areas and this included the repair of water, power, and sewage systems as well as street paving and sidewalk reconstruction. ${ }^{31}$

In 1986, the federal government created the Low Income Housing Tax Credit (LIHTC), which became the largest subsidy instrument for the production of affordable housing, after the elimination of project-based Section 8 housing. Through a bidding process, housing developers applied to local housing finance agencies for these tax credits to develop qualified properties. Developers who were awarded tax credits sold them to investors to raise capital for their projects. Investors received a dollar-for-dollar credit toward their federal tax liability for ten years. This system provided capital for the construction or rehabilitation of buildings, but not for their operation, meaning that rents were too expensive for low income people. ${ }^{32}$

The City of New York heavily relied on the LIHTC in its Ten-Year Housing Plan, though the HPD and the HDC used additional programs to make the housing more affordable and to prolong the affordable status of the developments. Besides providing the land and the buildings to be rehabilitated, the HPD used federal Section 8 vouchers that subsidized the rents of low income people. Additional subsidies that included the financing, operation, and capital improvements of some buildings extended the early generation of LIHTCs (1986-1990), which expired after fifteen years. In 1990, U.S. Congress added a second fifteen year affordability period for new LIHTCs. ${ }^{33}$

This system completed a policy shift from community development to institutionalized public-private partnerships. Public-private partnerships relied on powerful nonprofit umbrella intermediaries that managed housing programs by facilitating complicated relationships among government agencies, foundations, CDCs, community organizations, faith-based organizations, private owners, developers, builders, financial institutions, insurance companies, and investors, in contrast to CDCs often funded by HUD. The HPD worked in partnership with these nonprofit intermediaries whose staff became familiar with the landscape of low income neighborhoods, responsible landlords and developers, and fundraising techniques. Nonprofit intermediaries acted as regulators safeguarding the interests of investors by requiring CDCs to conform to paperwork and accounting standards, so that irregularities could be avoided. They also became involved in the LIHTC scheme by keeping track of the operation of low income developments and making sure that they complied with federal expectations, so that the tax benefits of investors would continue. Developers tried to meet the requirements of these nonprofit intermediaries, because they wanted to continue receiving LIHTCs and other public and private funding for new developments. While this independent safeguarding saved public money, intermediaries maintained stronger connections with landlords rather than tenants. ${ }^{34}$

The South Bronx became a major location for low income housing development during the Ten-Year Housing Plan with many nonprofit intermediaries operating there. One such nonprofit intermediary was the Community Preservation Corporation (CPC). Founded by David Rockefeller, CEO of Chase Manhattan Bank, in 1974 the CPC convinced major banks in New York to assist owners repair their apartment buildings located in working class neighborhoods. In the 1980s the CPC intensified its activities and during the Ten-Year Housing Plan it collaborated with the HPD in the Vacant Buildings Program. Local landlords with good records were selected 
to bid for vacant properties, rehabilitate them, and become their owners. The CPC became the organization that streamlined a complicated process and provided these owners with technical support, loans, mortgages, government funds, and tax credits. The LISC did something similar. It selected a few reliable CDCs, helped them acquire vacant city properties for one dollar each, and marketed financial packages of LIHTCs for all the CDCs in concert to raise money for construction. The city government covered the rest of the costs and offered low interest mortgages to buyers. The Enterprise Foundation (EF) was another intermediary that used a number of nonprofit organizations to develop areas under the state's Housing Trust Fund program. $^{35}$

While the nonprofit intermediaries usually maintained good relations with the city government, faith-based organizations that were affiliated with the Industrial Areas Foundation (IAF) did not during the Koch administration. Such organizations under the name of East Brooklyn Churches had been successful in building and rehabilitating thousands of homes in Brooklyn under the Nehemiah program, which received assistance by the Koch administration in the early 1980s. When the Ten-Year Housing Plan was launched, faith-based organizations of the South Bronx that were affiliated with the IAF tried to bring Nehemiah to their borough. The city government refused to offer the group a contract to rehabilitate Site 404 and presented alternative development locations. The South Bronx churches rejected this offer as inadequate and declared war against the Koch administration. ${ }^{36}$

The Nehemiah case in the South Bronx showed the extent to which not all organized interests were accommodated under this housing plan by the Koch administration. Powerful intermediaries enjoying the financial support of wealthy sponsors and institutions did well. Grassroots organizations that had previously been involved in community development were frequently avoided by the government unless they linked with a nonprofit intermediary, partly because the city administration, was embroiled in a number of scandals and wanted to make sure that the housing program remained clean, while at the same time reducing bureaucratic safeguards that slowed housing construction. The New York City Housing Partnership (NYCHP), a nonprofit intermediary whose president and CEO Kathryn S. Wilde was closely allied to Rockefeller. Wilde had heavily criticized the city government for bureaucratic hurdles to actually constructing housing. Despite these criticisms, the city administration selected the NYCHP after the winner of the bid to develop Site 404 withdrew, partly to avoid dealing with IAF and the South Bronx churches, and partly because of hopes that Wilde's organization would speedily increase the number of completed units. ${ }^{37}$

The Ten-Year Housing Plan was conceived by the Koch administration at a time of extreme criticism over its handling of the homeless crisis of New York City. In the 1980s, the number of homeless people visible in public space increased substantially, despite the city's extensive construction of homeless shelters after emergency court orders. Homeless advocates argued that gentrification contributed to the displacement of low income residents from their homes and that the city government did not do enough to prevent the conversion of Single Room Occupancies (SROs) and other inexpensive dwellings into luxury housing. More than this, the budgetary austerity that Koch pursued between 1978 and 1984 added to the social and economic problems of thousands of low income New Yorkers while housing in working class neighborhoods was being destroyed. As president of the Borough of Manhattan, Dinkins emerged as one of Koch's fiercest critics, especially on issues concerning housing and homelessness. Dinkins criticized Koch's housing plan for excluding the poorest New Yorkers and the homeless. He asked James R. Dumpson, an expert on poverty who had held high posts in 
all city administrations since 1959 , to chair a task force on the homeless. In a report released by Dinkins's office, the task force called for a substantial increase in housing allocated to the homeless and for a restructuring of the welfare shelter allowance. In fact, Dinkins wanted to make the new housing truly affordable and to have social service agencies rather than private owners operate it. Koch administration officials brushed aside these criticisms and claimed that Dinkins's housing proposals were tremendously expensive; Koch always viewed his housing plan as an economic development mechanism and dismissed government-operated housing as a welfare program. Although some of the housing built went to homeless families, throughout his tenure Koch attacked the homeless as being unworthy, refusing to work, and taking advantage of valuable city resources. ${ }^{38}$

In 1989, Dinkins constructed an electoral coalition that he called a "Gorgeous Mosaic" consisting of blacks, Latinos, and liberal whites and defeated Koch in the Democratic primary; Dinkins went on to prevail in the general election against Giuliani and become New York's first African American mayor. Koch's dream of being elected for a fourth term was not realized because in the late 1980s the city's economy faltered, racial antagonism persisted, and crime increased. Koch's continuous verbal attacks against African Americans convinced many New Yorkers that he could not unite the city. In the mayoral campaign, Dinkins spoke of racial rapprochement and rejected Koch's divisive rhetoric. Dinkins also criticized Koch's half-hearted homeless policy, his neglect of low income populations, and the city administration's tax giveaways to corporations and real estate developers. ${ }^{39}$

As mayor, Dinkins enlarged the Ten-Year Housing Plan and modified it. Despite an erosion of the city's finances and the inability of the HDC to market bonds at optimal levels, the Dinkins administration spent more than double in HPD capital funds than the Koch administration. This amounted to an average of $\$ 895,058,756$ (adjusted to 2013 dollars) spent per year in 1990-93 as opposed to $\$ 359,300,121$ per year in 1987-89 (Figure 9). To be sure, capital expenses could have increased had Koch remained mayor and the 1990 budget was initially appropriated by his administration, though Dinkins maintained it and even enhanced it. Moreover, the HDC sold \$354,010,956 in bonds (adjusted to 2013 dollars) per year in 1987-89 as opposed to $\$ 246,543,816$ per year in $1990-93$. Still, Dinkins was quite committed to the success of this housing plan and spent more. Dinkins also modified the housing plan by making thousands of units more affordable, by setting aside more of the housing for homeless people, and by directly involving more CDCs. ${ }^{40}$

The city administration's actions were influenced by arguments that approximately twothirds of the housing units constructed under Koch were market-rate and allocated to middle and upper middle class people. While such reports overstated the situation, the Koch administration did not provide as many subsidies for the operation of housing, meaning that many low income people could not afford it. The Dinkins administration modified this and changed the character of the housing plan. By 1998, low income households occupied two-thirds of the government constructed or rehabilitated housing units. Moderate income households occupied a quarter while the middle class lived in less than 10 percent of this housing. But the Dinkins administration encountered many problems. Housing production and rehabilitation during the Koch years was easier because large parcels of abandoned land could be redeveloped and developers took advantage of economies of scale. From 1990 onward, mostly smaller, more scattered sites remained available for development, which increased costs. Moreover, the public-private partnership structure that rose in the 1980s persisted and community input remained limited. Many of the CDCs, which used to be grassroots organizations were no longer representatives of 
local resident interests, but had evolved into organizations characterized by market-type relationships. As the city's economy deteriorated even more, Dinkins was forced to cut the capital budget for housing. While capital expenditures for housing increased by 50.5 percent in 1990 and another 16.5 percent in 1991, they declined by 9.3 percent in 1992 and another 34.1 percent in 1993 (Figure 9). This negatively affected many community-based projects, given that smaller CDCs lacked the financial resources of nonprofit intermediaries and private developers. Housing for homeless people also proved too costly and was not as extensive as envisioned. ${ }^{41}$

The South Bronx benefitted in the Dinkins years and received an increased allotment of apartments. Much of this was the doing of Felice L. Michetti who was appointed commissioner of HPD. Michetti was a housing expert, served as first deputy commissioner of HPD in the last four years of the Koch administration, and had championed low income housing initiatives by community groups at a time that the city government was unenthusiastic toward them. Under Dinkins, Michetti who had grown up in the Bronx and attended Fordham University, used her connections with local organizations to smooth out relations with the South Bronx churches that had been alienated by Koch. While she did not renegotiate the contract of Site 404, she offered them better alternative development sites under more generous terms than Koch. Other South Bronx CDCs were also given more deals and added responsibilities. ${ }^{42}$

In 1993, Giuliani defeated Dinkins and was elected mayor. Giuliani had accused Dinkins of perpetuating the city's involvement in housing ownership and vowed to seek private participation. His administration made the privatization of city-owned housing a priority. Indeed in 1994 the City of New York owned 30,358 housing units. By the end of Giuliani's tenure as mayor in 2001 this number had decreased to 8,299 . While too many buildings were sold hastily and cheaply, fewer city-owned buildings allowed the HPD to use its operational budget for other purposes. Giuliani also slashed the HPD capital budget initially. Continuing problems with city finances did not allow additional spending, though Giuliani was also not as interested in having the government construct housing. He did not cancel the Ten-Year Housing Plan, but he reduced the capital commitments of the city. At the same time, these capital budgets stabilized after the mid-1990s and the city continued to rehabilitate or construct some housing throughout his mayoralty. Adjusted to 2013 figures, HPD's annual capital expenditures did not go below $\$ 318,359,800$ and in the end the Giuliani administration averaged $\$ 424,122,739$ annually, which was higher than the 1986-89 figure (Figure 9). In some ways, the Ten-Year Housing Plan went beyond its original duration and became permanent, though expenditures never reached the high levels of the Dinkins years, the rehabilitation or construction of housing became more expensive, some of the money was spent on the preservation of affordable housing, and Giuliani did not consider the physical rebuilding of neighborhoods by the government as an accomplishment. ${ }^{43}$

According to surveys of the U.S. Census Bureau, between 1980 and 2000 the South Bronx gained 17,423 units. In the 1980s, the South Bronx lost 2,575 units because the housing starts of the late 1980s under the Ten-Year Housing Plan did not offset the losses. In the 1990s the South Bronx gained 19,998 units (Figure 4). This number represents a net gain given that housing is always lost. According to Alex Schwartz between 1986 and 1997, the City of New York under the Ten-Year Housing Plan funded housing starts for new construction and gut rehabilitation of 22,397 units in the South Bronx. Between 1994 and 2000, the HDC funded the creation of 2,350 housing units. Overall, 53,706 housing units benefitted from New York City capital programs in the South Bronx in 1987-2001. From these 31.4 percent were vacant and the overwhelming majority, 83.7 percent underwent major rehabilitation. While only 16.3 percent of the units were newly constructed, it is always more expensive to develop new buildings and not 
desirable to continue having thousands of vacant ones. These gains were nowhere near the 90,394 housing units lost in the 1970s, though the city government made a calculated decision to rebuild at lower densities and focus on land coverage. Indeed by the late 1990s, one no longer encountered the vast landscapes of abandonment that used to define the South Bronx. The population of the South Bronx grew from 463,118 in 1980 by 19 percent to 550,945 in 2000 (Figure 2). ${ }^{44}$

\section{Housing in the South Bronx under the New Housing Marketplace, 2002-2013}

In 2013, in his weekly radio appearance on WOR-AM, Mayor Michael R. Bloomberg claimed that lack of affordable housing is an indicator of a vibrant economy, because so many people find the city attractive and want to live there. Although Bloomberg had a valid point, many housing advocates characterized his arguments as insensitive, since that the city lost thousands of affordable housing units from 2002-2013. For many New Yorkers the cost of housing became a dominant campaign issue in the mayoral election of 2013, given that housing expenditures increased during Bloomberg's mayoralty (Figure 10). ${ }^{45}$

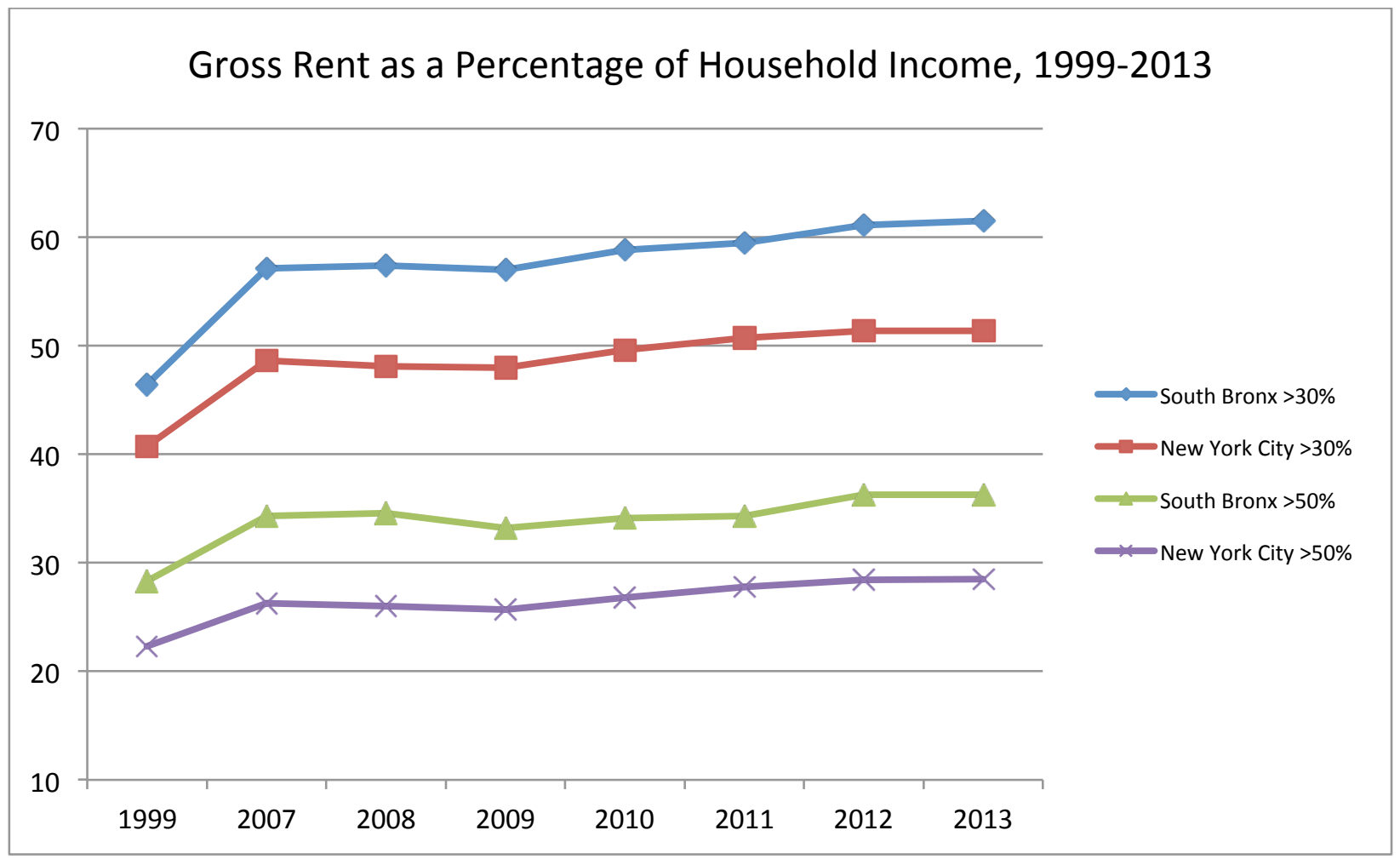

Figure 10. Gross rent as a percentage of household income in the South Bronx and New York City, 1999-2013. This figure shows the percentage of households paying more than 30 percent of their income on rent as well as the percentage of households paying more than 50 percent of their income on rent. Housing expenditures that exceed 30 percent of household income have historically been viewed as an indicator of a housing affordability problem. Source: U.S. Census Bureau survey of 2000 and the Three-Year American Community Surveys of 2007-2013. 
Michael Bloomberg was elected mayor in 2001 and remained in office from 2002-2013 after winning reelection twice. Unlike his predecessors, Bloomberg was a multi-billionaire businessman with no political experience. In the mayoral elections Bloomberg used his own personal wealth and outspent his opponents by tens of millions of dollars. While New York City had taken a neoliberal political-economic path since the Koch administration, under Bloomberg this neoliberal vision reached new heights with the corporate world having more direct influence in government. Bloomberg filled many of the crucial positions that dealt with economic development, large projects, and overall policy with affluent members of the corporate world. These appointees favored big businesses and developers and sought to attract to the city more large corporations and affluent people from around the world. At the same time, city budgets continued to grow (Figure 5) with Bloomberg viewing the provision of quality municipal services as a foundation of economic growth. ${ }^{46}$

Wanting to remake the physical landscape of New York City and eager to deflect criticisms that he only favored private market-rate development, Bloomberg developed his own ambitious housing plan. In 2002, he announced the New Housing Marketplace Plan (NHMP), pledging to preserve or create 65,000 affordable housing units in five years. In 2005, he amended the NHMP into a ten-year plan that would preserve or create 165,000 units of housing by 2013 . Much of the plan focused on the preservation of existing affordable housing whose subsidies were going to expire. Besides the construction of rental housing for low- and moderate-income people, this plan included a major homeownership component for moderate-, middle-, and even upper-middle income people. The plan used the remainder of city-owned land to build housing and even pursued strategies to find new land through rezoning, land banking, and public-private partnerships. The city administration also provided generous incentives and tax breaks to the private sector, so that market-rate housing could be built and even tried to harness these entities to include affordable housing in their developments. However, this was largely voluntary and most developers chose not to include such housing in their luxury condominiums. The NHMP was financed by the HDC and the HPD. The HDC was given permission to increase its borrowing limit and to borrow against its equity. Taking advantage of a growing economy, a robust housing market in New York, and a good fiscal management record, the HDC became the nation's largest housing finance agency. Its ability to market bonds continued even during the Great Recession. As Marc Jahr, president of the HDC from 2008-2014, stated "during the downturn, when nobody was building in Manhattan, we were financing construction in the neighborhoods ... Cranes that were absent from the Manhattan skyline were up in the Bronx because of our financing." 47 On the average, the HDC issued bonds and notes worth $\$ 1,336,286,126$ each year (adjusted to 2013 figures) in the 2002-2013 period. Some additional money came from the HDC's corporate reserves and other sources. The HPD, which worked closely with the HDC, spent on the average an additional $\$ 434,118,389$ each year from its capital budget. When combined, these amounts were higher than those spent annually in the 1986-2001 period for housing (Figure 9). However, the construction of new housing and even rehabilitation cost significantly more in 2002-2013 than before. ${ }^{48}$

Bloomberg administration officials heralded the NHMP as the largest municipal housing effort in the history of the nation, though the meaning of this statement remains unclear. It is possible that more money was spent for the NHMP than any other municipal housing program in the United States, but this did not translate into the largest housing production. Between 2004 and 2013, the NHMP preserved the affordable status of 106,540 of housing units and built 45,811 new ones. In addition, 39.1 percent of the housing built under the NHMP was for 
homeowners. The cost of this housing for homeowners was a bargain while regulations would keep these prices affordable for a number of years. At the same time, despite their affordability, these housing units were not for low income populations and barely served people with moderate incomes. ${ }^{49}$

In the first decade of the twenty-first century, the number of occupied housing units in the South Bronx increased by 16,311 (Figure 4). By 2013 the NHMP had helped finance approximately 37,000 affordable units in the South Bronx (Figure 11). Less than half were new construction with the majority being existing affordable units whose status was preserved. Almost all of this housing comprised of rentals for low- and moderate-income people. Indeed out of 194,536 occupied housing units in the South Bronx, only 12,790 were owner-occupied in 2010 slightly up from 12,162 in 2000. The population of the South Bronx increased by 7.4 percent in the 2000s, reaching the figure of 591,661 people (Figure 2). ${ }^{50}$

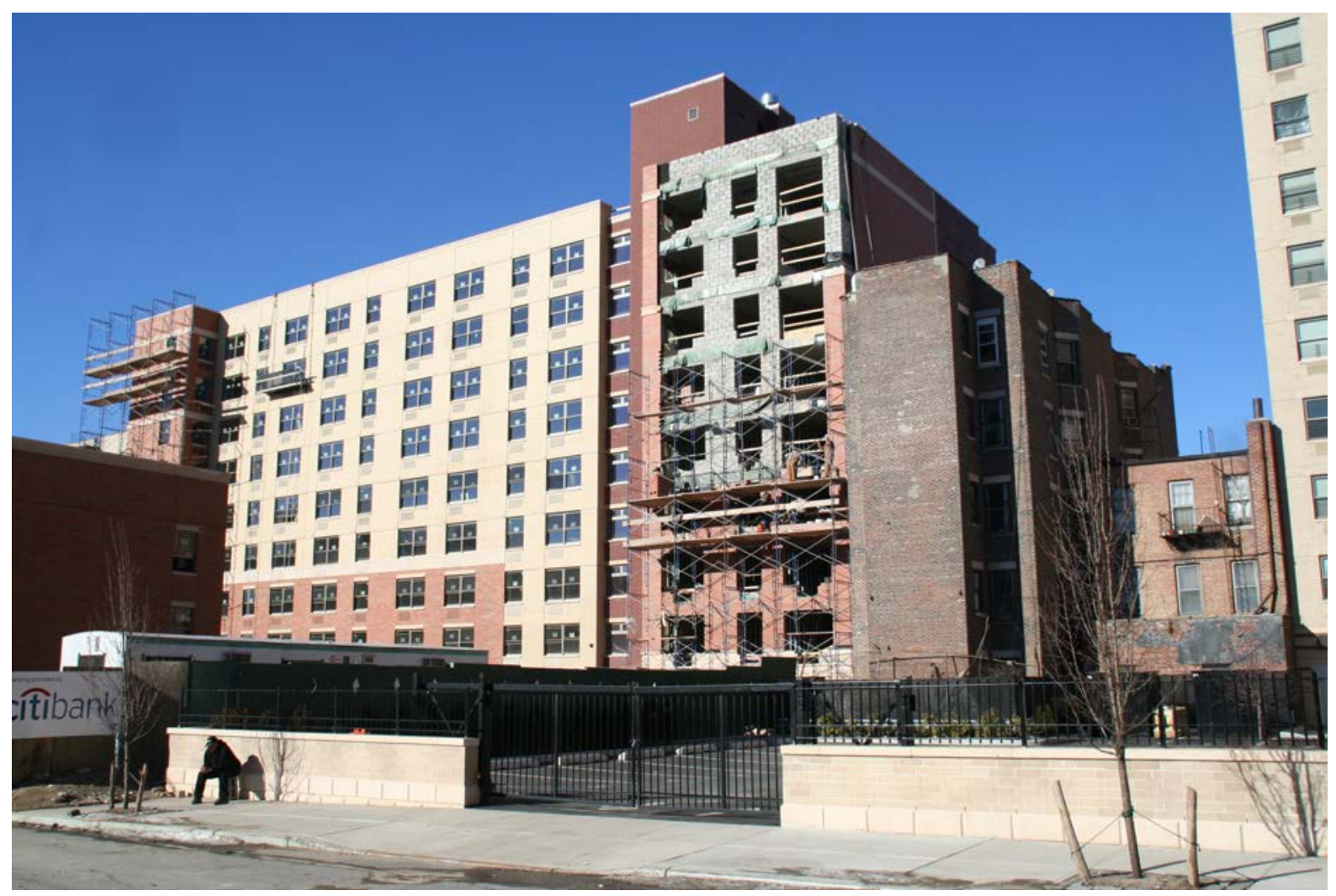

Figure 11. New construction in the South Bronx under the New Housing Marketplace Plan. Source: Photo taken by the author, 2007.

The citywide loss of affordable housing in the 2000s did not affect the South Bronx significantly, because the city government stepped up and preserved almost all of the units whose affordable status was expiring. Indeed only 8.9 percent of all rentals were under no regulation in 2002; by 2011 this figure had increased to 11.5 percent, which is not substantial and could be a transitional matter, given that the NHMP was still in the process of preserving the affordability of housing units. The city administration took this road in the South Bronx because of fears that deregulated housing could fail. There were also fears of a humanitarian crisis, given that more than 70,000 low income people could potentially face displacement in the case of 
deregulation. The Great Recession further dissuaded many landlords from deregulating, given that cost-benefit analyses showed that accepting subsidies from the government in the South Bronx was a sounder decision. ${ }^{51}$

While the great majority of housing remained regulated in the South Bronx, the rise in housing costs represents a worrisome trend. Up until the early 2000s increases in the median household income matched and even surpassed increases in median gross rent. In the years that followed, incomes stagnated and declined while rents continued to increase (Figure 12). One could argue that this is a problem of income rather than a problem of housing costs. Still, more and more households in the South Bronx are burdened by higher housing expenditures. The percentage of households in the South Bronx spending more than $30 \%$ of their income for rent surpassed the $60 \%$ figure in 2012. Moreover, more than $36 \%$ of households spend more than half of their income for rent (Figure 10). Although these trends resemble citywide ones, the burden in the South Bronx is higher. Given that many of these households have no significant savings, they are quite vulnerable to housing loss, if something suddenly goes wrong.

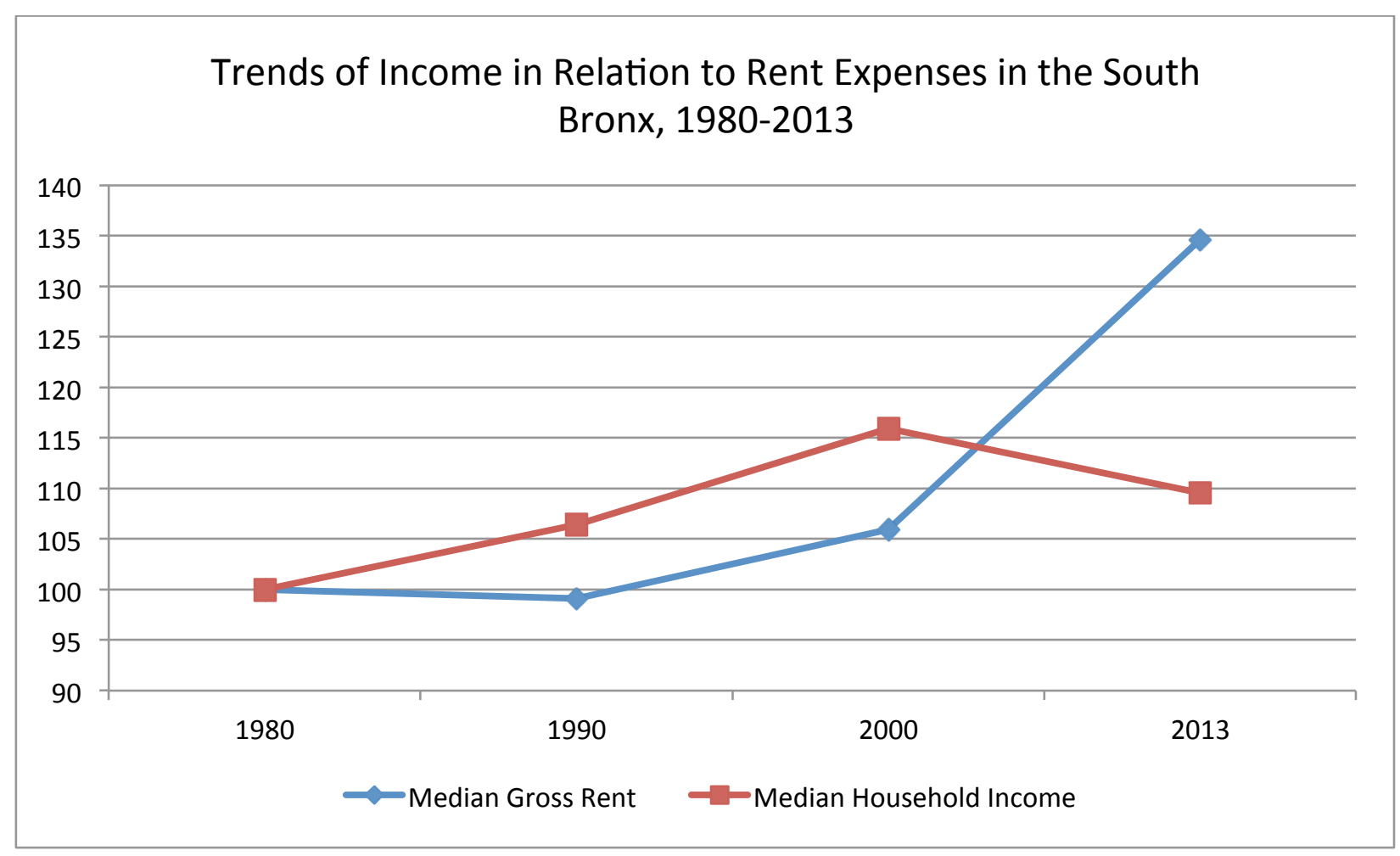

Figure 12. Trends of median household income in relation to median gross rents in the South Bronx, 1980-2013. Index: Year $1980=100$. Source: U.S. Census Bureau surveys, 1980-2000, and the Three-Year American Community Survey, 2013.

\section{Conclusion}

Efforts to rebuild the South Bronx, which was the city's largest contiguous devastated area in postwar New York, began in 1977 and materialized after 1986. The continuity of this rebuilding is staggering given that four successive and very different city administrations insisted in transforming the South Bronx into an area with almost no abandoned housing and empty lots. Since 1980 the South Bronx has gained approximately 34,000 housing units, almost all of which 
were built or rehabilitated because of initiatives by the city government combining federal, state, city, and private money. More than this, the affordability of thousands of units was renewed in the 2000s when original subsidies were expiring. This represents a rare case for our era of successful government action, using public-private partnerships to rebuild a vast urban area with housing that is affordable.

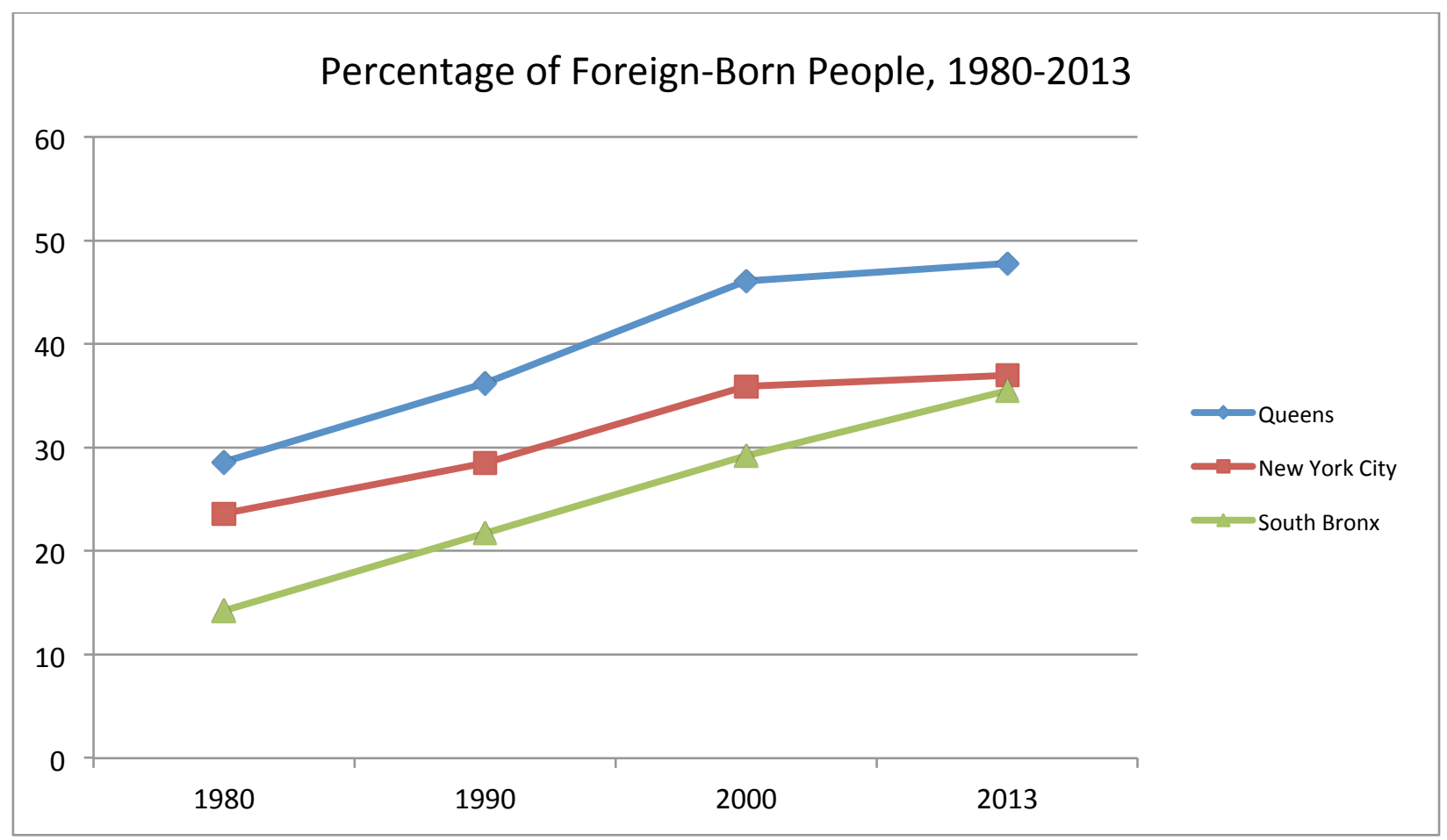

Figure 13. Foreign-Born People as a percentage of the entire population. The areas surveyed are the South Bronx, New York City in its entirety, and Queens, the borough with the highest proportion of immigrants. Source: U.S. Census Bureau surveys, 1980-2000, and the Five-Year American Community Survey, 2013.

The population of the South Bronx increased from 463,118 in 1980 to 591,661 in 2010 (Figure 2) with a great percentage of these newcomers being immigrants. In 1980, only 14.2 percent of people living in the South Bronx were foreign-born; by 2013, this figure had more than doubled to 35.5 percent (Figure 13). To be sure this figure is lower than the city average, and smaller compared to Queens, the borough with the largest proportion of immigrants in New York City. However, the number of immigrants has been growing faster in the South Bronx than in most other places (Figure 14). In the 1970s, many immigrants moving to New York avoided the South Bronx, which was losing housing and was experiencing severe socioeconomic problems. This began to change in the 1980s and continued unabated in the decades that followed. Lower rental prices have made the South Bronx increasingly attractive to newcomers and to working class immigrants living in other boroughs. In 2010, the number of foreign-born people living in the South Bronx was 203,887. ${ }^{52}$ 


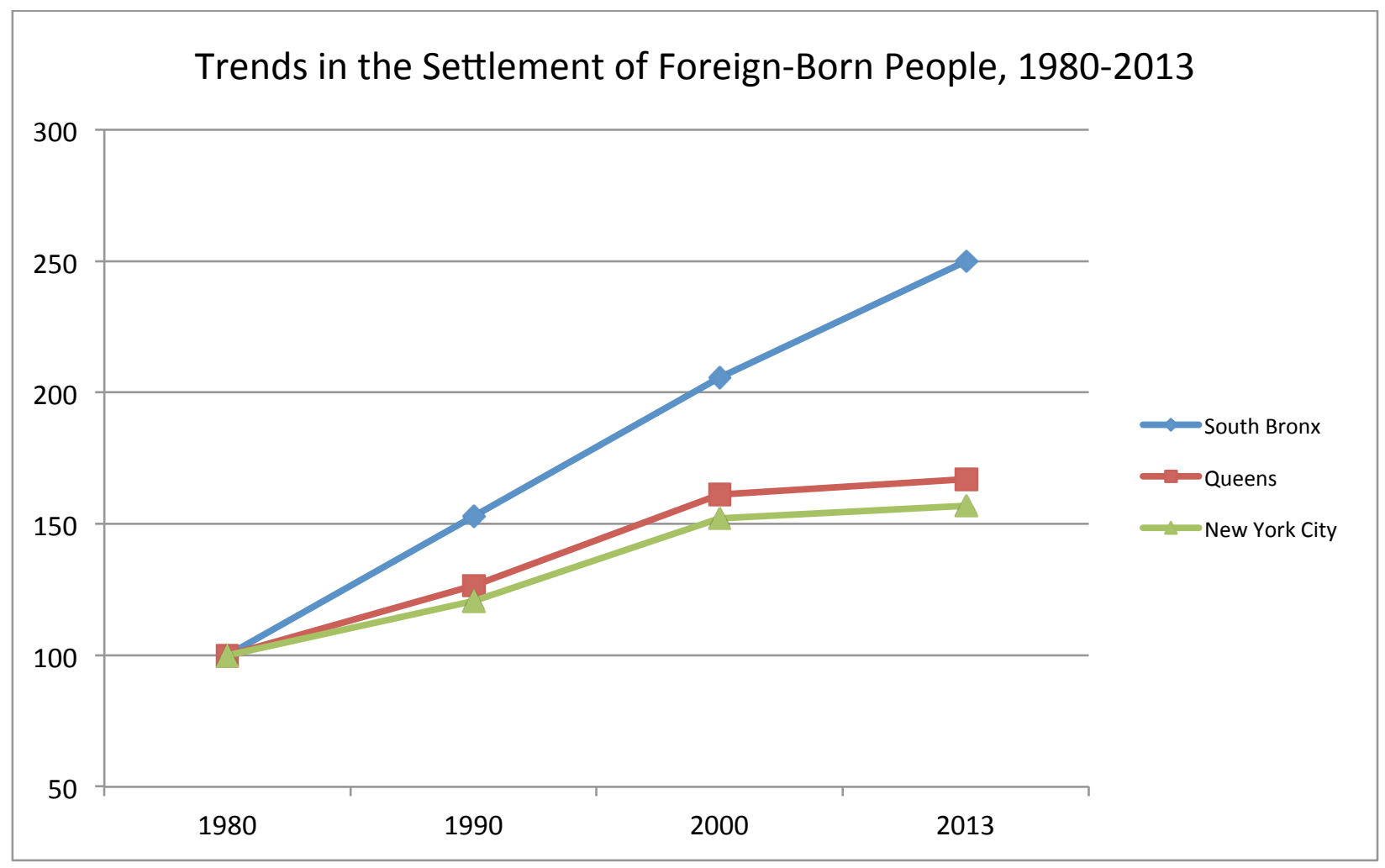

Figure 14. Trends in the settlement of foreign-born people in the South Bronx, New York City, and Queens since 1980. Index: Year $1980=100$. Source: Graph created by the author after consulting Social Explorer, the U.S. Census Bureau surveys, 1980-2000, and the Five-Year American Community Survey, 2013.

Unlike other distressed urban areas in the United States, the South Bronx was able to reinvent itself because of a large influx of immigrants in the post-fiscal crisis era; still, if not for the new housing, the great majority of these people would not have moved to the South Bronx and in this sense the city government deserves credit for the area's revitalization. Although so called empty or abandoned spaces are always occupied by people, and informal settlements whose residents included immigrants were formed in many parts of New York in the 1970s and the 1980s, it is doubtful that these spaces would have attracted the thousands of families that have relocated to the South Bronx.

As I have argued elsewhere, urban areas in the United States are becoming increasingly diverse, though this diversity in the South Bronx involves mostly Latinos and blacks (Figure 15). In 1980, Puerto Ricans and African Americans dominated the social makeup of the area. In the decades that followed the population diversified. In terms of Latinos, Dominicans became the largest group numerically in the 2000s overtaking Puerto Ricans. The number of Mexicans has been increasing geometrically since 1980, though the group remains a distant third. Other Latino groups with smaller but sizable numbers include Hondurans, Ecuadorians, Salvadorans, Guatemalans, Cubans, Colombians, Peruvians, Nicaraguans, and Panamanians. According to the 2010 census, 66.1 percent of South Bronx residents were Latino. In terms of groups of African descent excluding Latinos, African Americans still constitute an overwhelming majority. 
However, the numbers of people from Subsaharan Africa have been increasing with approximately 35,000 people living in the South Bronx by 2010. Ghanaians comprise the largest group of Subsaharan Africans with Nigerians being a distant second and Senegalese third. There are also about 18,000 West Indians, though their numbers have not grown since 1990 and slightly declined in the 2000s. Jamaicans are the majority of West Indians in the South Bronx while many other countries from the region are also represented. At the same time, the racial and ethnic makeup of the South Bronx shows the extent to which racial segregation is persisting in the United States. A contiguous urban area with approximately 600,000 people has almost no whites or Asians (Figure 15). And while these trends are complex and may have to do with housing policy, immigrant networks, and social geography, the population of the South Bronx is also segregated by class. ${ }^{53}$

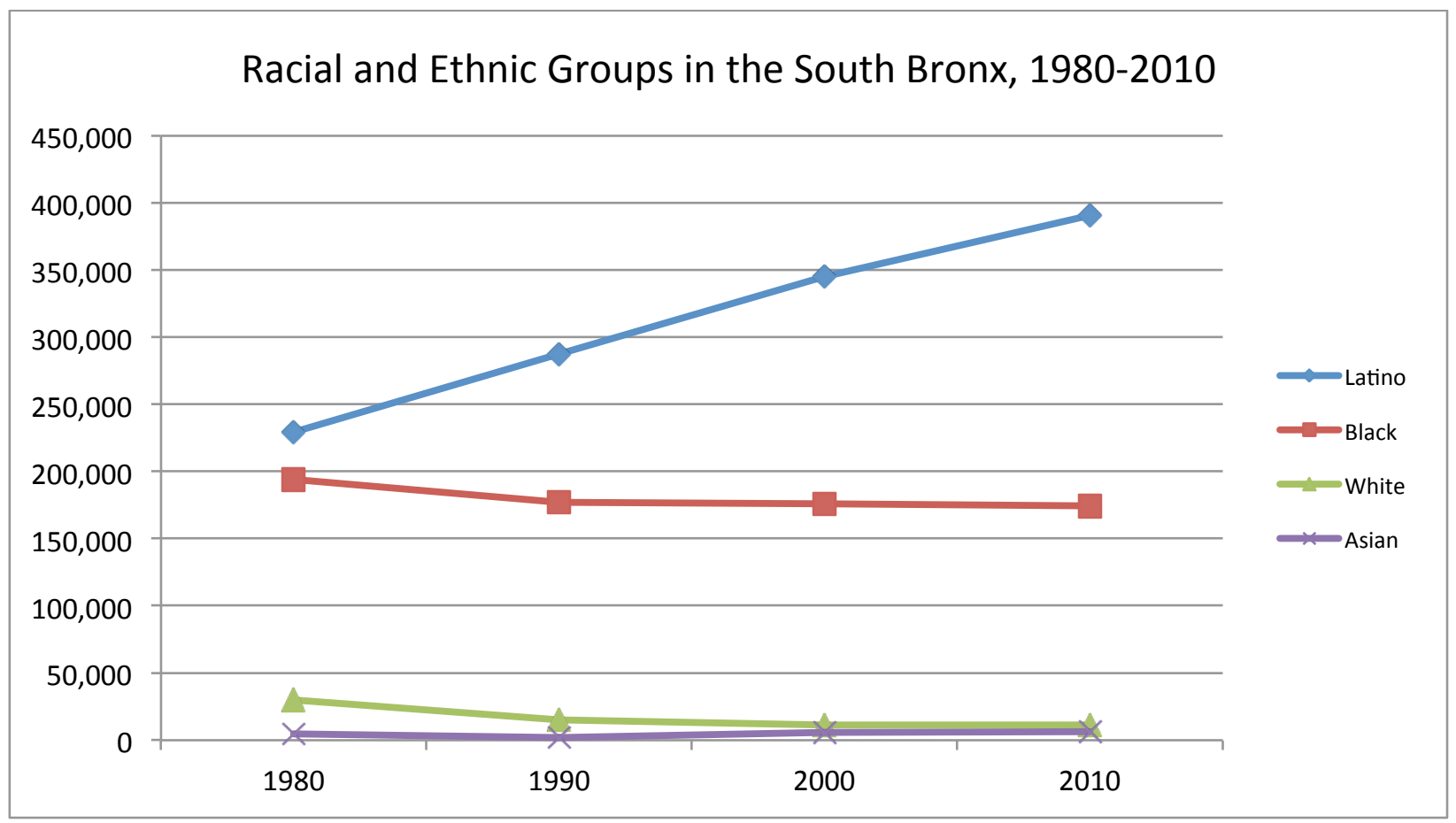

Figure 15. Racial and ethnic groups in the South Bronx, 1980-2010 in actual population numbers. Source: U.S. Census Bureau surveys, 1970-2010.

The population of the South Bronx is near the bottom of New York's income hierarchy. Adjusted for inflation, the annual median household income on the South Bronx has remained almost stable since 1980 , reaching the $\$ 25,789$ figure in 2000 , before declining to $\$ 24,401$ in 2013 (all of these figures in 2013 dollars). The median household income of the South Bronx is significantly lower from that of the Bronx in its entirety. It is also less than half of the median household income of the entire city (Figure 16). In terms of occupation, the percentage of individuals involved in service employment has been rapidly increasing since 1970, reaching the figure of 39.4 percent in 2013 (Figure 17). These jobs are among the lowest paying. Only 15.8 percent of working adults had managerial or professional occupations in 2013, which were usually the best paying. Given the occupation indicators, it is not surprising that there are many more families living in poverty in the South Bronx than in the Bronx and New York City. 


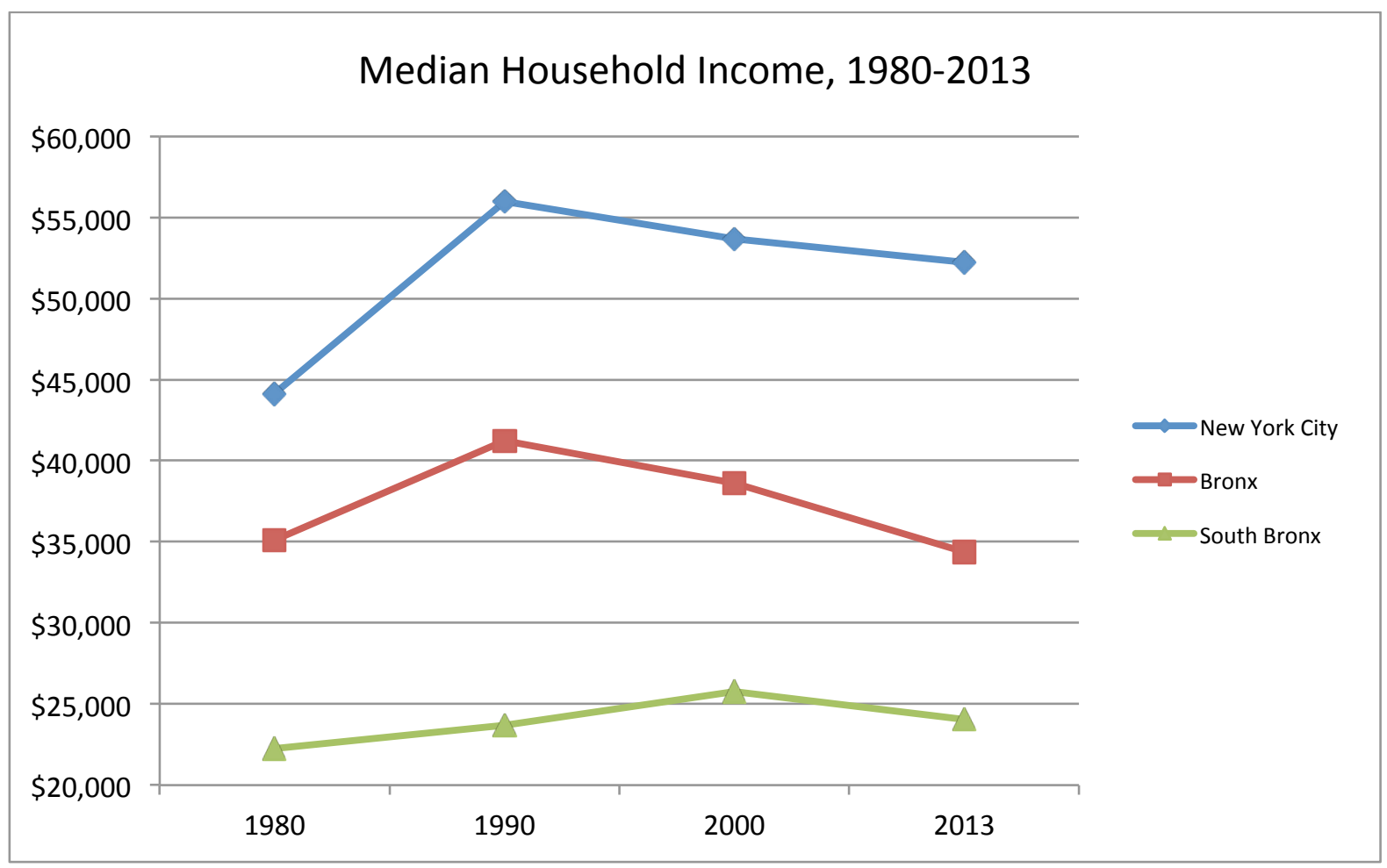

Figure 16. Median household income in 2013 inflation-adjusted dollars in New York City, the Bronx, and the South Bronx. Source: U.S. Census Bureau Surveys, 1980-2000, and the FiveYear American Community Survey, 2013.

Despite the low incomes and high poverty rates, the South Bronx remains a stable area and inexpensive housing contributes significantly toward that goal. To be sure, since 2000, incomes have been slowly declining while rents, despite regulations and subsidies, have been increasing. In 2000, the median gross rent in the South Bronx was \$737. By 2013, it had increased by 23.9 percent, reaching the figure of $\$ 937$ (all figures in 2013 dollars). During the same period, median households incomes declined by 7 percent. The rent increases have occurred for various reasons. The affordable housing of the NHMP is more expensive than previous housing schemes. More than this, rent-stabilized units are subject to periodic rent increases that are expected to cover inflation and higher maintenance charges. Still, these rents remain inexpensive enough to allow low income people to live there, it is just that the trend at the moment appears to be troublesome. 


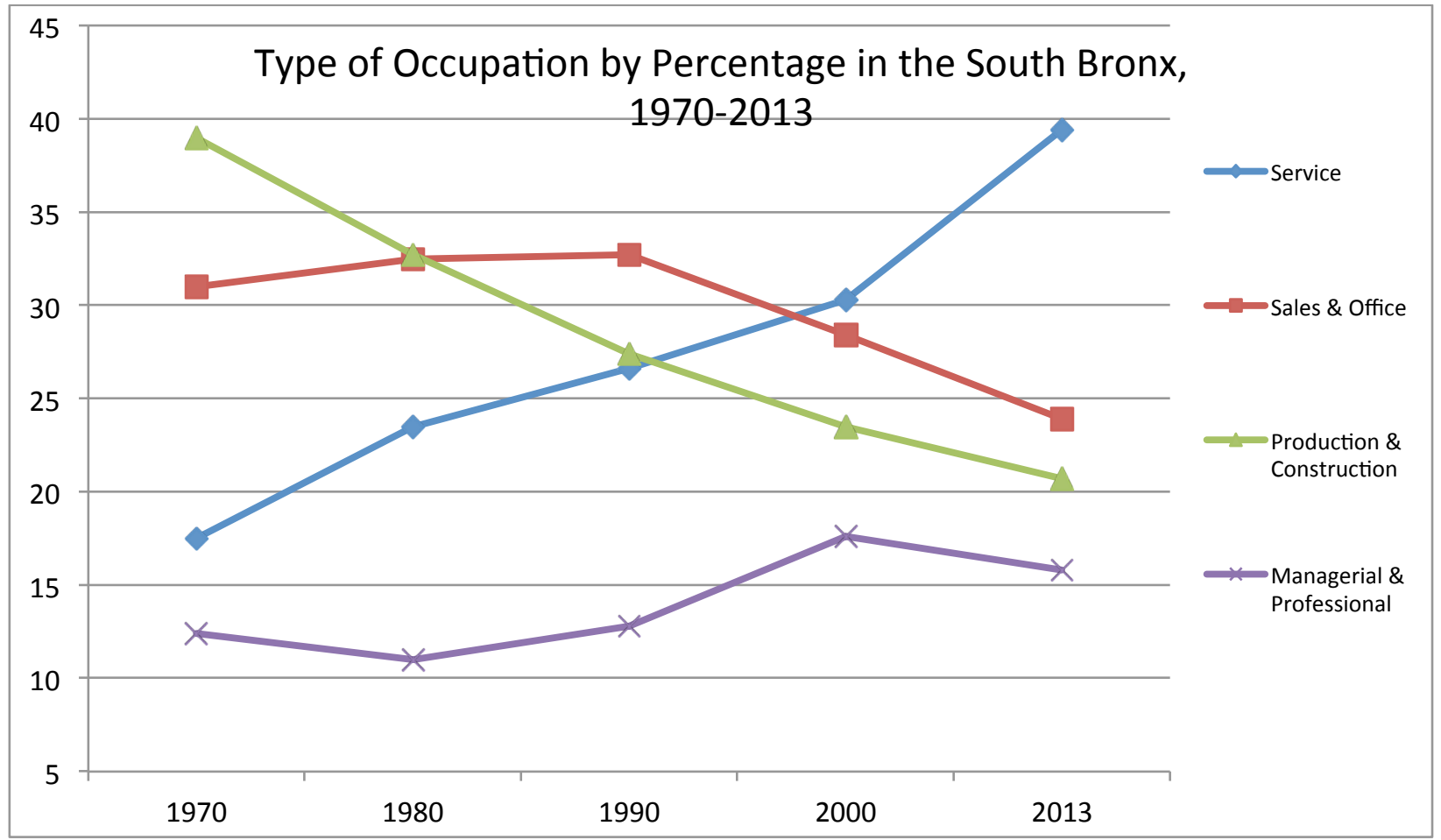

Figure 17. Type of occupation by percentage, 1970-2013. Source: U.S. Census Bureau Surveys, 1970-2000, and the Five-Year American Community Survey, 2013. 


\title{
Notes
}

\begin{abstract}
${ }^{1}$ Martin Tolchin, "South Bronx: A Jungle Stalked by Fear, Seized by Rage," New York Times, January 15, 1973, 1 and 19.

${ }^{2}$ Patrick Watson, The 51st State ((South Bronx Gangs) (New York: WNET, October 2, 1972); Norman Rose, New York Illustrated: Saturday Night at Fort Apache (New York: WNBC, February 23, 1973); Selwyn Raab, The 51st State (Juvenile Justice) (New York: WNET, November 8, 1973); Paul Franklin Stein, New York Illustrated. Portrait: Ghetto Hospital (New York: WNBC, December 8, 1974); Alan Raymond and Susan Raymond, The Police Tapes (New York: WNET, 1977); Bill Moyers, CBS Reports: The Fire Next Door (New York: CBS, 1977); Richard Pierce, Siege (New York: CBS, April 26, 1978); Helen Whitney, ABC News Close Up. Youth Terror: The View from Behind the Gun (New York: ABC, June 28, 1978); Tom Shales, "Disquieting Desperation in the Big City," The Washington Post, August, 1 1978, C1; Michael Houldey, Only in America (London: Thames, 1980); Flora Lewis, "West Africa's Creeping Democracy," New York Times, May 4, 1981, A23; James Feron, "The Children Revolt in Liverpool's South Bronx," New York Times, August 6, 1982, A6.
\end{abstract}

${ }^{3}$ City of New York, Summary: The South Bronx: A Plan for Revitalization (New York: The City, 1977), 2; U.S. Census Bureau surveys, 1970 and 1980.

${ }^{4}$ Although the term South Bronx has been used at various times in the history of the borough, its boundaries have shifted and are subject to debate. By the 1970s, the South Bronx generally denoted the area south of Fordham Road and west of Bronx River and this could be seen in official city government documents. This is the area designated as the South Bronx in this article and includes the following 136 Bronx County Census Tracts (2010 U.S. Census): 19, 23, 25, $27.01,27.02,31,33,35,37,39,41,43,51,53,59.02,61,63,65,67,69,71,73,75,77,79,83$, $85,87,89,93,115.02,117,119,121.01,121.02,123,125,127.01,129.01,131,133,135,141$, $143,145,147.01,147.02,149,151,153,155,157,159,161,163,165,167,169,171,173,175$, $177.01,177.02,179.01,179.02,181.01,181.02,183.01,183.02,185,189,193,195,197,199$, 201, 205.01, 205.02, 209, 211, 213.01, 213.02, 215.01, 215.02, 217, 219, 221.01, 221.02, 223, $225,227.01,227.02,227.03,229.01,229.02,231,233.01,233.02,235.01,235.02,237.02$, $237.03,237.04,239,241,243,245.01,245.02,247,249,251,253,255,257,359,361,363$, 365.01, 365.02, 367, 369.01, 369.02, 371, 373, 375.04, 379, 381, 383.01, 383.02, 385, 387, 389, 391, 393, 395, and 399.02. It comprises of the following neighborhoods: Mott Haven, Melrose, Hunts Point, Longwood, Morrisania, Crotona, Highbridge, Concourse, Fordham, University Heights, Belmont, and East Tremont.

5 Joseph P. Fried, “City's Housing Administrator Proposes 'Planned Shrinkage' of Some Slums," New York Times, February 3, 1976, 35.

${ }^{6}$ U.S. Census Bureau Surveys, 1970 and 1980. While I use the terms "abandoned" and "vacant" some of the damaged buildings had squatters and other occasional or permanent occupants. 
${ }^{7}$ A significant percentage of the 1976-1981 budgets went to debt service further reducing the money available for operating expenses. About New York's fiscal crisis see William K. Tabb, The Long Default: New York City and the Urban Fiscal Crisis (New York: Monthly Review Press, 1982); Martin Shefter, Political Crisis/Fiscal Crisis: The Collapse and Revival of New York City (New York: Columbia University Press, 1992); City of New York, Annual Report of the Comptroller of the City of New York, Volumes: 1966-1981.

${ }^{8}$ Harrison Rainie, “U.S. Housing Program in South Bronx Called a Waste by Moynihan," Daily News, December 20, 1978, 3.

${ }^{9}$ Gordon J. Davis, City Planning Commissioner, Letter to the Editor, “On 'Shrinking' Our Poor Neighborhoods," New York Times, February 11, 1976, 44; Thomas A. Johnson, "Rohatyn Scored by Congressmen," New York Times, March 17, 1976, 18; Joseph P. Fried, "Starr, New York City's Housing Chief, Will Leave Post by Fall, Officials Say," New York Times, May 22, 1976, 24. Moynihan's view is articulated at length in Peter D. Salins, The Ecology of Housing Destruction: Economic Effects of Public Intervention in the Housing Market (New York: New York University Press for the International Center for Economic Policy Studies, 1980).

${ }^{10}$ New York City Planning Commission, 6100 New Homes in Air-Rights and Parkland: A Plan for Melrose-Morrisania (New York: The Commission, 1971); Robert A. M. Stern, David Fishman, and Jacob Tilove, New York 2000: Architecture and Urbanism Between the Bicentennial and the Millennium (New York: Monacelli Press, 2006), 1212-3.

${ }^{11}$ City of New York, A Bronx Housing Strategy (New York: The City, 1977); Jill Jonnes, South Bronx Rising: The Rise, Fall, and Resurrection of an American City (New York: Fordham University Press, 2002), 311-23; City of New York, Summary: The South Bronx: A Plan for Revitalization (New York: The City, 1977); Peter Eisinger, "The Search for a National Urban Policy: 1968-1990," Journal of Urban History 12 (November 1985): 3-23;

Stuart Meck and Rebecca Retzlaff, "President Jimmy Carter's Urban Policy: A Reconstruction and an Appraisal," Journal of Planning History 11 (August 2012): 242-80; Yvonne ScruggsLeftwich, Consensus and Compromise: Creating the First National Urban Policy under President Carter (New York: University Press of America, 2006). Tracy Neumann, "Privatization, Devolution, and Jimmy Carter's National Urban Policy," Journal of Urban History 40 (March 2014): 283-300.

12 Jonathan Soffer, Ed Koch and the Rebuilding of New York City (New York: Columbia University Press, 2010), 181-3; Louis K. Loewenstein, “The New York State Urban Development Corporation - A Forgotten Failure or a Precursor of the Future?" Journal of the American Institute of Planners 44 (July 1978): 261-73; Hilary Botein, "New York State Housing Policy in Postwar New York City: The Enduring Rockefeller Legacy," Journal of Urban History 35 (September 2009): 833-52.

13 Department of City Planning, Proposal for the South Bronx (New York: The Department, 1978); Joseph P. Fried, "Estimate Board Votes South Bronx Housing Project," New York Times, November 17, 1978, B4; Soffer, Ed Koch and the Rebuilding of New York City, 184-5. 
14 “Badillo Deplores New Koch Plan on South Bronx,” New York Times, August 15, 1979, B4.

${ }^{15}$ Editorial, "Smaller Is Sounder in the Bronx," New York Times, August 20, 1979, A20.

${ }^{16}$ South Bronx Development Office, "Request for $\$ 4,000,000$ Start-Up Funds for South Bronx Effort Jointly Financed by Federal and State Governments," November 1, 1978, Special Collections, Lehman College Library, City University of New York, Bronx, New York; South Bronx Development Office, Areas of Strength, Areas of Opportunity: South Bronx Revitalization Program and Development Guide Plans (New York: The Office, 1980).

${ }^{17}$ Alexander von Hoffman, House by House, Block by Block: The Rebirth of America's Urban Neighborhoods (New York: Oxford University Press, 2003), 24-34; Jonnes, South Bronx Rising, 300-23; Jim Rooney, Organizing the South Bronx (Albany: State University of New York Press, 1994); Evelyn Gonzalez, The Bronx (New York: Columbia University Press, 2004), 130-7; Harris Beider, "The Rise and Fall (and Rise) of Community Development Corporations and Minority Ethnic Housing Associations," in Harris Beider, ed., Neighbourhood Renewal \& Housing Markets: Community Engagement in the US \& UK (Oxford: Blackwell, 2007), 233-5; Tom Angotti, New York for Sale: Community Planning Confronts Global Real Estate (Cambridge: The MIT Press, 2008); Roger Biles, The Fate of Cities: Urban America and the Federal Government, 1945-2000 (Lawrence: University Press of Kansas, 2011), 160-249; Neumann, "Privatization, Devolution, and Jimmy Carter's National Urban Policy," 294-5.

${ }^{18}$ Robert McFadden, "Derelict Tenements in the Bronx to Get Fake Lived-in Look," New York Times, November 7, 1983, B5.

${ }^{19}$ Edward I. Koch Letter to the Editor, "Of Decals and Priorities for the South Bronx," New York Times, November 19, 1983, 24.

20 The greening of the South Bronx was discussed in detail by Adam Charboneau in his paper entitled "The Koch Administration, Private Foundations, and the Greening of the South Bronx: Utilizing Local Sweat-equity Efforts in the Advancement of Capital and Spatial Deconcentration of the Urban Poor," presented at the Urban History Association conference in Philadelphia in 2014. It will appear in Adam Charboneau, "Sustaining New York: Struggles Over Space in the Big Apple, 1965-2001," (Ph.D. diss., State University of New York, Stony Brook, 2016). Other writings about the greening of New York City from the 1970s onward include: Mark Francis, Lisa Cashdan, and Lynn Paxson, Community Open Spaces: Greening Neighborhoods through Community Action and Land Conservation (Covelo: Island Press, 1984); Karen Schmelzkopf, "Incommensurability, Land Use, and the Right to Space: Community Gardens in New York City," Urban Geography 23 (2002): 323-43. For the beautification of buildings with vinyl decals see Themis Chronopoulos, Spatial Regulation in New York City: From Urban Renewal to Zero Tolerance (New York: Routledge, 2011), 126-8.

${ }^{21}$ von Hoffman, House by House, 36-9; Jonnes, South Bronx Rising, 376-88; Rebecca A. Lee, "The Affordable Option: Charlotte Street Manufactured Housing," in Eugenie Ladner Birch, ed., The Unsheltered Woman: Women and Housing (New Brunswick: Transaction Publishers, 2012), 
277-82; Brent D. Ryan, Design After Decline: How America Rebuilds Shrinking Cities (Philadelphia: University of Pennsylvania Press, 2012), 24-30; David W. Dunlap, "Suburban Housing Grows in Brooklyn," New York Times, 2 May 1982, E6.

${ }^{22}$ William R. Greer, "Housing Plan Goes Awry In the Bronx," New York Times, February 13, 1985, B1.

${ }^{23}$ von Hoffman, House by House, 39; Jonnes, South Bronx Rising, 389-92; Roberta Brandes Gratz, The Living City: How America's Cities Are Being Revitalized by Thinking Small in a Big Way (New York: Simon \& Schuster, 1989), 122-46.

${ }^{24}$ von Hoffman, House by House, 37.

${ }^{25}$ Benjamin Holtzman, "I am Not Co-Op!" The Struggle over Middle-Class Housing in 1970s New York," Journal of Urban History (this section); U.S. Census Bureau Survey, 1980.

${ }^{26}$ Richard Ronald, The Ideology of Home Ownership: Homeowner Societies and the Role of Housing (Basingstoke: Palgrave MacMillan, 2008); Edward Scanion, "Low-Income Homeownership Policy as a Community Development Strategy," Journal of Community Practice 5 (1998): 137-54; Mechele Dickerson, Homeownership and America's Financial Underclass: Flawed Premises, Broken Promises, New Prescriptions (New York: Cambridge University Press, 2014).

${ }^{27}$ Soffer, Ed Koch and the Rebuilding of New York City, 290-1; Gregg G. Van Ryzin and Andrew Genn, "Neighborhood Change and the City of New York's Ten-Year Housing Plan," Housing Policy Debate 10 (1999): 799-838; Office of the Mayor, Report of the Mayor's Panel on Affordable Housing (New York: The City, 1986); In Rem Working Group, Building from Experience: The Next Step for in rem Housing: A Report to the Mayor (New York: New York Urban Coalition, 1986); Office of the Mayor, Affordable Housing for New Yorkers: City Assisted Housing since 1978 (New York: The City, 1989); Department of Housing Preservation and Development (hereafter HPD), The Ten-Year Plan (New York: The Department, 1989).

${ }^{28}$ Michael A. Stegman, The Dynamics of Rental Housing in New York City (New Brunswick: Center for Urban Policy Research, Rutgers University, 1983); Michael A. Stegman, Housing in New York: Study of a City, 1984 (New Brunswick: Center for Urban Policy Research, Rutgers University, 1985); Independent Budget Office of the City of New York (hereafter IBO), Agency Expenditures, 1980-2014 (New York: The Office, 2015).

${ }^{29}$ Soffer, Ed Koch and the Rebuilding of New York City, 298; New York City Municipal Water Finance Authority, Annual Report (New York: The Authority, 1986); New York City Housing Development Corporation (hereafter HDC), Annual Report: November 1, 1971 to October 31, 1972 (New York: HDC, 1972); HDC, 1987, 1988, 1989, 1990, 1991, and 1992 Annual Report (New York: HDC, 1987-1992). 
${ }^{30}$ The HPD is separate from the New York City Housing Authority (NYCHA), which is in charge of public housing and the Department of Buildings, which enforces city and state law by inspecting buildings, examining building plans, enforcing zoning regulations, as well as issuing construction permits and certifications of occupancy. The HPD and the Department of Buildings became separate agencies in 1977 when Mayor Beame dismantled a superagency called Housing and Development Administration. This superagency had been created by Mayor John V. Lindsay in the 1960s.

${ }^{31}$ City of New York, Message of the Mayor: Executive Budget, Fiscal Year 1987, 1988, 1989, and 1990 (New York: The City, 1986-1989). There was an assumption, which was originally made by Badillo, that the infrastructure of portions of the South Bronx was in good condition and that the area only needed housing. This was mostly inaccurate and as time went on the existing infrastructure was increasingly becoming obsolete.

${ }^{32}$ Biles, The Fate of Cities, 250-317; Alex F. Schwartz, Housing Policy in the United States (New York: Routledge, 2014), 135-61.

33 Tom Waters and Victor Bach, Good Place to Work, Hard Place to Live: The Housing Challenge for New York City's Next Mayor (New York: Community Service Society, 2013), 213.

${ }^{34}$ Schwartz, Housing Policy in the United States, 135-61; Waters and Bach, Good Place to Work, Hard Place to Live, 21-4; Kathryn Wylde, "The Contribution of Public-Private Partnerships to New York's Assisted Housing Industry," in Michael H. Schill, ed., Housing and Community Development in New York City: Facing the Future (Albany: State University of New York Press, 1999), 73-91; Beider, "The Rise and Fall (and Rise) of Community Development Corporations and Minority Ethnic Housing Associations," 234.

${ }^{35}$ von Hoffman, House by House, 48-72; Soffer, Ed Koch and the Rebuilding of New York City, 290-304; Lee Stuart, "CCome, Let Us Rebuild the Walls of Jerusalem': Broad-Based Organizing in the South Bronx," in Robert D. Carle and Louis A. DeCaro, Jr., eds., Signs of Hope in the City (Valley Forge: Judson Press, 1999), 159-69; William Sites, "The Limits of Urban Regime Theory: New York City under Koch, Dinkins, and Giuliani," Urban Affairs Review 32 (March 1997): 544-5; Wylde, "The Contribution of Public-Private Partnerships to New York's Assisted Housing Industry," 73-91; Brian Sahd, "Community Development Corporations and Social Capital: Lessons from the South Bronx," in Robert Mark Silverman, Community-Based Organizations: The Intersection of Social Capital and Local Context in Contemporary Urban Society (Detroit: Wayne State University Press, 2004), 85-121; Gonzalez, The Bronx, 137-44.

${ }^{36}$ Jim Rooney, Organizing the South Bronx (Albany: State University of New York Press, 1995), 137-234; Ingrid Gould Ellen, Michael H. Schill, Scott Susin, and Amy Ellen Schwartz, "Building Homes, Reviving Neighborhoods: Spillovers from Subsidized Construction of Owner-Occupied Housing in New York City," Journal of Housing Research 12 (2001): 185-216.

${ }^{37}$ Rooney, Organizing the South Bronx, 137-234 
${ }^{38}$ Chronopoulos, Spatial Regulation in New York City, 128-38; Peter Marcuse, "Gentrification, Abandonment, and Displacement: Connections, Causes, and Policy Responses in New York City," Journal of Urban and Contemporary Law 28 (January 1985): 195-240; James R. Dumpson and David N. Dinkins, A Shelter is not a Home: Report of the Manhattan Borough President's Task Force on Housing for Homeless Families (New York: Office of the Manhattan Borough President, 1987); Soffer, Ed Koch and the Rebuilding of New York City, 295; David N. Dinkins with Peter Knobler, A Mayor's Life: Governing New York's Gorgeous Mosaic (New York: Public Affairs, 2013), 117-23 and 181.

${ }^{39}$ John H. Mollenkopf, A Phoenix in the Ashes: The Rise and Fall of the Koch Coalition in New York City Politics (Princeton: Princeton University Press, 1992), 165-89; Ryan Reft, "The Limits of Black Pragmatism: The Rise and Fall of David Dinkins, 1989-1993," Souls: A Critical Journal of Black Politics, Culture, and Society 10 (January-March 2008): 6-10; J. Phillip Thompson, III, Double Trouble: Black Mayors, Black Communities, and the Call for a Deep Democracy (New York: Oxford University Press, 2006), 182-92; Chronopoulos, Spatial Regulation in New York City, 138.

${ }^{40}$ IBO, Agency Capital Expenditures, 1985-2013 (New York: The Office, 2015); City of New York, The Mayor's Management Report, September 1990, 1991, 1992, and 1993 (New York: The City, 1990-1993).

${ }^{41}$ Bonnie Brower, Missing the Mark: Subsidizing Housing for the Privileged, Displacing the Poor (New York: Association of Neighborhood and Housing Development and the Housing Justice Campaign, 1989); Don Terry, "Dinkins Expands Housing Plan to Assist the Poor," New York Times, May 17, 1990, B3; Alan S. Oser, "Putting a Dinkins Imprint on a Koch Plan," New York Times, July 8, 1990, R5; Sahd, "Community Development Corporations and Social Capital," 85-121; Sites, "The Limits of Urban Regime Theory," 547-8; Alex Schwartz, "New York City and Subsidized Housing: Impacts and Lessons of the City's \$5 Billion Capital Budget Housing Plan," Housing Policy Debate 10 (1999): 845.

42 Rooney, Organizing the South Bronx, 177-91; Bruce Lambert, "Way Cleared for LongDelayed Housing," New York Times, April 14, 1991, R1; David Gonzalez, "In the South Bronx, the Grass Roots Grow Up," New York Times, January 7, 1993, B1.

${ }^{43}$ Celia W. Dugger, "Giuliani Calls Dinkins Indecisive on Housing and Homeless," New York Times, August 5, 1993, B1; IBO, Agency Capital Expenditures, 1985-2013 (2015); City of New York, Mayor's Management Report, 1994, 1995, 1996, 1997, 1998, 1999, 2000, and 2001 (New York: The City, 1994-2001); Schwartz, "New York City and Subsidized Housing," 839-77; Michael H. Schill, Ingrid Gould Ellen, Amy Ellen Schwartz, and Ioan Vocu, "Revitalizing InnerCity Neighborhoods: New York City's Ten-Year Plan," Housing Policy Debate 13 (2002): 52966.

${ }^{44}$ U.S. Census Bureau Surveys, 1980-2000; Schwartz, "New York City and Subsidized Housing," 862; HDC, 2000 Annual Report (New York: The Corporation, 2000), 11; Denise Wallin, 
Michael H. Schill, and Glynis Daniels, State of New York City's Housing and Neighborhoods 2002 (New York: Furman Center for Real Estate and Urban Policy, New York University, 2002), $36,39,42,45,48$, and 51 .

${ }^{45}$ Mara Gay, "Mayor Bloomberg Says New York City's Lack of Affordable Housing is a 'Good Sign' of a Vibrant Economy because 'More People Want to Live Here',' Daily News, October 18, 2013; Moon Wha Lee, Selected Findings of the 2002 New York City Housing and Vacancy Survey (New York: HPD, 2003), 1-3; Moon Wha Lee, Housing New York City, 2011 (New York: HPD, 2011), 93; Elyzabeth Gaumer and Sheree West, Selected Initial Findings of the 2014 New York City Housing and Vacancy Survey (New York: HPD, 2015).

${ }^{46}$ Julian Brash, "The Ghost in the Machine: The Neoliberal Urban Visions of Michael Bloomberg," Journal of Cultural Geography 29 (June 2012): 135-53; Themis Chronopoulos, "Congestion Pricing: The Political Viability of a Neoliberal Spatial Mobility Proposal in London, Stockholm, and New York City," Urban Research \& Practice 5 (July 2012): 195-6; Themis Chronopoulos, "Urban Spatial Mobility in the Age of Sustainability," in Stephen Zavestoski and Julian Agyeman, eds., Incomplete Streets: Processes, Practices and Possibilities (New York: Routledge, 2015), 54-76; Scott Larson, "Building Like Moses with Jacobs in Mind”: Contemporary Planning in New York City (Philadelphia: Temple University Press, 2013).

${ }^{47}$ HDC, 2012 Annual Report (New York: The Corporation, 2012), 10.

${ }^{48}$ HPD, The New Housing Marketplace: Creating Housing for the Next Generation (New York: The Department, 2002); HPD, The New Housing Marketplace: Creating Housing for the Next Generation (New York: The Department, 2005); HPD, Progress Report 2005 (New York: The Department, 2005); HPD, New Housing Marketplace Plan: Creating A More Affordable, Viable, and Affordable City for All New Yorkers (New York: The Department, 2010); Susan S. Fainstein, "The Return of Urban Renewal: Dan Doctoroff's Grand Plans for New York City," Harvard Design Magazine No. 22 (Spring/Summer 2005): 1-5; Themis Chronopoulos, "The Politics of Race and Class and the Changing Spatial Fortunes of the McCarren Pool in Brooklyn, New York, 1936-2010," Space and Culture 16 (February 2013): 115-9; Larson, "Building Like Moses with Jacobs in Mind," 77-96 and 133-53; HDC, 2002, 2003, 2004, 2005, 2006, 2007, 2008, 2009, 2020, 2011, 2012, and 2013 Annual Report (New York: The Corporation, 2002-2013); IBO, Agency Capital Expenditures, 2002-2013 (2015).

${ }^{49}$ HPD, The New Housing Marketplace Plan, 2003-2014: A Decade of Investment in New Yorkers and their Neighborhoods (New York: The Department, 2013), 5. More such housing was built after 2013 with the total reaching approximately 165,000 units.

${ }^{50}$ U.S. Census Bureau Surveys, 2000 and 2010; HPD, NHMP 160,000 and Counting to 165,000 (New York: The Department, 2013).

${ }^{51}$ State of New York City's Housing and Neighborhoods 2003 (New York: Furman Center for Real Estate and Urban Policy, New York University, 2003), 20; Lee, Housing New York City, $2011,529$. 
${ }^{52}$ Nancy Foner, ed., One Out of Three: Immigrant New York in the Twenty-First Century (New York: Columbia University Press, 2013); Leonard Dinnerstein and David M. Reimers, The World Comes to America: Immigration to the United States Since 1945 (New York: Oxford University Press, 2012); Aristide R. Zolberg, A Nation by Design: Immigration Policy in the Fashioning of America (Cambridge: Harvard University Press, 2006); U.S. Census Bureau Surveys, 1980-2010.

53 Themis Chronopoulos, "The Multiethnic Neighborhood in the United States," Journal of Urban History 40 (March 2014): 388-94; U.S. Census Bureau Surveys, 1980-2010. 